\title{
DE88 007231
}

\author{
ENVIRONMENTAL ASSESSMENT \\ RELATED TO THE \\ OPERATION OF \\ ARGONNE NATIONAL LABORATORY \\ ARGONNE, ILLINOIS
}

August 1982

Prepared for

U.S. Department of Energy

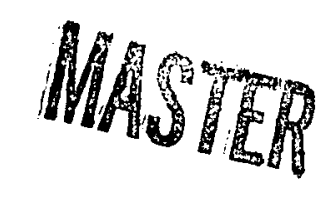

This document is

PUBLICLY RELEASABLE

B Staols

Authorizing Official

Date:

$9.12-07$

Q 


\section{DISCLAIMER}

This report was prepared as an account of work sponsored by an agency of the United States Government. Neither the United States Government nor any agency Thereof, nor any of their employees, makes any warranty, express or implied, or assumes any legal liability or responsibility for the accuracy, completeness, or usefulness of any information, apparatus, product, or process disclosed, or represents that its use would not infringe privately owned rights. Reference herein to any specific commercial product, process, or service by trade name, trademark, manufacturer, or otherwise does not necessarily constitute or imply its endorsement, recommendation, or favoring by the United States Government or any agency thereof. The views and opinions of authors expressed herein do not necessarily state or reflect those of the United States Government or any agency thereof. 


\section{DISCLAIMER}

Portions of this document may be illegible in electronic image products. Images are produced from the best available original document. 
This Environmental Assessment (EA) was prepared in accordance with the National Environmental Policy Act of 1969 (NEPA-42 USC 4231) to facilitate agency planning and decisionmaking (40 CFR 1501.3(b)). The EA covers the operations conducted by the U. S. Department of Energy (DOE) at the Argonne, Illinols, site of the Argonne National Laboratory (ANL). Included are the contractor-operated functions (ANL proper) and the DOE-operated New Brunswick Laboratory (NBL); hereafter, the total site operation is referred to simply as ANL. Other abbreviations used in this EA are listed and identified in Appendix A. 


\section{CONTENTS}

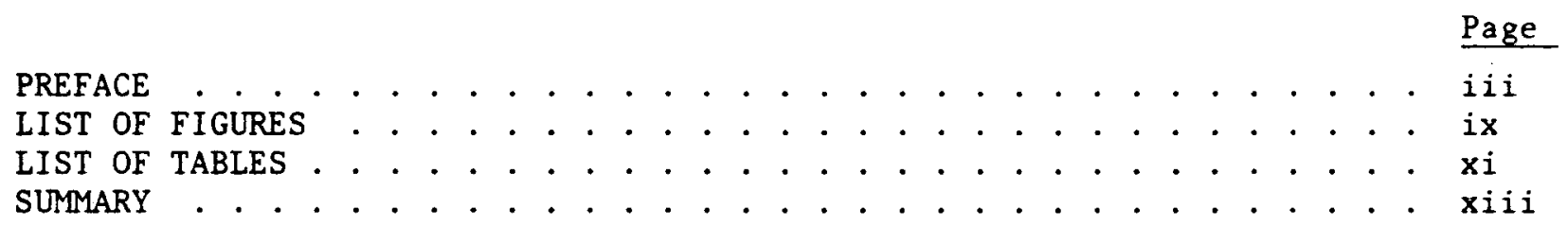

1. PROPOSED ACTION AND ITS ALTERNATIVES . . . . . . . . . . . . . . . . 1-1

1.1 Proposed Action . . . . . . . . . . . . . . . . . . . . . . 1-1

1.2 Alternatives Considered . . . . . . . . . . . . . . . . . 1-1

2. BACKGROUND . . . . . . . . . . . . . . . . . . . . . . . 2-1

2.1 Detailed Description of ANL . . . . . . . . . . . . . . . 2-1

2.1.1 Site History ..................... . 2-1

2.1.2 Administrative Structure . . . . . . . . . . . . . . . 2-1

2.1.3 Research and Development Activities... . . . . . . . . . . 2-2

2.1.4 Description of Current Facilities . . . . . . . . . . . . . . 2-4

2.1.4.1 Argonne Thermal Source Reactor . . . . . . . . . . . . 2-5

2.1.4.2 JANUS Reactor. . . . . . . . . . . . . . . . . . . 2-10

2.1.4.3 ZPR-6 and ZPR-9 ........................ 2-12

2.1.4.4 Alpha-Gamma Hot Cell Facility . . . . . . . . . . . . . . 2-12

2.1.4.5 Bldg. 310 Experiment Assembly Facility . . . . . . . . . 2-14

2.1.4.6 Bldg. 200, wing M................. 2-14

2.1 .4 .7 Bldg. 212, Special Facility FDl2 . . . . . . . . . . . 2-15

2.1.4.8 New Brunswick Laboratory . . . . . . . . . . . . . . 2-16

2.1.4.9 Gammabeam-650 Cobalt-60 Irradiator . . . . . . . . . 2-17

2.1.4.10 Special Nuclear Material Vaults . . . . . . . . . . . 2-18

2.1.4.11 Water Supply System . . . . . . . . . . . . . . 2-18

2.1.4.12 Waste Handling Facilities . . . . . . . . . . . . . . . 2-19

2.1.4.12.1 Sanitary Waste Treatment . . . . . . . . . . . . 2-19

2.1.4.12.2 Laboratory Waste Treatment . . . . . . . . . . 2-20

2.1.4.12.3 Liquid Waste Handling . . . . . . . . . . . . 2-22

2.1.4.12.4 Solid Waste Handling............. . . 2-24

2.1.4.13 Boiler Plant . . . . . . . . . . . . . . . 2-26

2.1.4.14 Particle Accelerators . . . . . . . . . . . . . 2-26

2.2 Characterization of the Existing Environment . . . . . . . . . . 2-28

2.2.1 General Description of the ANL Site . . . . . . . . . . . . 2-28

2.2.2 Geology, Soils, and Seismology . . . . . . . . . . . . 2-32

2.2.2.1 Geology . . . . . . . . . . . . . . . . . . . 2-32

2.2.2.2 Soils........................ . 2-33

2.2.2.3 Seismology . . . . . . . . . . . . . . . . . . 2-33

2.2.3 Demography and Social Profile.............. . 2-33

2.2.3.1 Demography of the Area and Vicinity . . . . . . . . . 2-33

2.2.3.2 Socioeconomic Profile... . . . . . . . . . . 2-34

2.2 .4 Land Resources .. . . . . . . . . . . . . . . . 2-36 
2.2 .5 Climate and Meteorology ................ . 2-37

2.2.5.1 General .................... . . 2-37

2.2.5.2 Winds..................... 2-38

2.2.5.3 Precipitation .. . . . . . . . . . . . . 2-38

2.2 .5 .4 Storms .................... . . 2-39

2.2.5.5 Air Quality.................. . . 2-39

2.2 .6 Water Resources... . . . . . . . . . . . . . . . 2-43

2.2.6.1 Surface Water... . . . . . . . . . . . . . 2-43

2.2.6.2 Groundwater.... . . . . . . . . . . . . $2-45$

2.2.7 Cultural Resources ................. . 2-45

2.2 .8 Ecology .. . . . . . . . . . . . . . . . . . 2-47

2.2.8.1 Terrestrial Ecology ............... . . 2-47

2.2.8.2 Aquatic Ecology .. . . . . . . . . . . . . . . . 2-50

2.2.8.3 Endangered and Threatened Species . . . . . . . . . . 2-58

2.2.9 Background Radiation Characteristics . . . . . . . . . . . . 2-58

2.3 Effluent and Environmental Monitoring Programs . . . . . . . . 2-61

2.3.1 Nonradioactive .. . . . . . . . . . . . . . 2-61

2.3.1.1 Air . . . . . . . . . . . . . . . . . . 2-61

2.3.1.2 Liquids... . . . . . . . . . . . . . . . 2-62

2.3.1.3 Solids . . . . . . . . . . . . . . . . . 2-62

2.3.2 Radioactive... . . . . . . . . . . . . . . . 2-62

2.3.2.1 Air....................... . . 2-62

2.3.2.2 Liquids . . . . . . . . . . . . . . . . . . 2-62

2.3 .2 .3 Solids ....................... 2-64

References (Section 2).................... . 2-64

3. ENVIRONMENTAL IMPACTS . . . . . . . . . . . . . . . . . . . . . . 3-1

3.1 Impacts Due to Routine Operations... . . . . . . . . . . . . 3-1

3.1.1 Introduction . . . . . . . . . . . . . . . . . . . . . 3-1

3.1.2 Description and Environmental Effects of Routine Releases. . 3-2

3.1.2.1 Nonradioactive Releases . . . . . . . . . . . . . . 3-2

3.1.2.1.1 Atmospheric Releases .. . . . . . . . . . . 3-2

3.1.2.1.2 Liquid Releases . . . . . . . . . . . . . . 3-4

3.1.2.1.3 Solid Wastes .. . . . . . . . . . . . . 3-10

3.1.2.1.4 Miscellaneous .. . . . . . . . . . . . . . 3-11

3.1.2.2 Radioactive Releases . . . . . . . . . . . . . 3-11

3.1.2.2.1 Atmospheric Releases .............. 3-11

3.1.2.2.2 Liquid Releases... . . . . . . . . . . . . 3-16

3.1.2.2.3 Solid Wastes .. . . . . . . . . . . . . 3-16

3.1.2.2.4 Direct Radiation . . . . . . . . . . . . . . 3-18

3.1.2.2.5 Well Water Radioactivity .. . . . . . . . . . 3-18

3.2 Impacts Due to Preemption of Natural Resources . . . . . . . 3-20

3.2.1 Land ....................... . . . 3-20

3.2 .2 Water........................ . 3-20

3.2.3 Energy . . . . . . . . . . . . . . . . . . . . 3-21

3.3 Additive Impacts . . . . . . . . . . . . . . . . . 3-22

3.3.1 Nonradioactive .. . . . . . . . . . . . . . . 3-22

3.3.2 Radioactive . . . . . . . . . . . . . . . 3-22 
Page

3.4 Impacts of Possible Accidents . . . . . . . . . . . . . . . . . 3-23

3.4.1 Introduction .................... . . 3-23

3.4.2 Classification of Accidents. . . . . . . . . . . . . 3-23

3.4.2.1 Explosions .................... . 3-24

3.4.2.2 Fires..................... . . 3-24

3.4.2.3 Accidental Criticality . . . . . . . . . . . . 3-24

3.4.2.4 Spills .................... . . 3-25

3.4.2.5 Natural Phenomena ................. . . 3-25

3.4.3 Accident Analysis and Consequences . . . . . . . . . . . 3-25

3.4.3.1 Explosions . . . . . . . . . . . . . . . . . . 3-25

3.4.3.1.1 NBL Glovebox Explosion .............. . 3-25

3.4.3.1.2 MSD Glovebox Explosion . . . . . . . . . . . . 3-26

3.4.3.2 Fires...................... . . 3-27

3.4.3.2.1 Uranium Fire ................. . . 3-27

3.4.3.2.2 Plutonium Fire . . . . . . . . . . . . . . . . . . . 3-28

3.4.3.3 Accidental Criticality . . . . . . . . . . . . . 3-28

3.4.3.3.1 Argonne Thermal Source Reactor . . . . . . . . . . 3-29

3.4.3.3.2 JANUS Reactor .. . . . . . . . . . . . . . . 3-30

3.4.3.3.3 ZPR-6 and ZPR-9 ................... . 3-30

3.4.3.3.4 Fissile Material Storage Facilities... . . . . . . 3-32

3.4.3.4 Spills .. . . . . . . . . . . . . . . . . . 3-33

3.4.3.4.1 Nonradioactive Spill . . . . . . . . . . 3-33

3.4.3.4.2 Radioactive Spill . . . . . . . . . . . . . . 3-33

3.4.3.5 Natural Phenomena . . . . . . . . . . . . . 3-34

3.4.3.5.1 Floods ................... . 3-35

3.4.3.5.2 Earthquakes ................ . . 3-35

3.4.3.5.3 Tornadoes . . . . . . . . . . . . . . . . 3-35

3.4.3.6 Transportation Accidents . . . . . . . . . . . 3-45

3.4.4 Summary of Accidents . . . . . . . . . . . . . . . . . . 3-45

3.5 Continuing Effects of Past Operations... . . . . . . . . . . . 3-48

3.5.1 Plutonium Glovebox Storage . . . . . . . . . . . . . . 3-48

3.5.2 Radionuclides in Offsite Soil. . . . . . . . . . . . . 13-48

3.5.3 Suspect Waste Landfill . . . . . . . . . . . . . . . . . . . 3-49

3.5.4 Effluent from Experimental Boiling Water Reactor . . . . . . 3-49

3.5.5 Contamination in Sewage Treatment Area . . . . . . . . . 3-49

3.5.6 Unused Excavation . . . . . . . . . . . . . . . . 3-50

3.5.7 Disposal of Reactive Chemicals . . . . . . . . . . . . 3-50

3.5.8 Disposal of Liquid Wastes in Landfill . . . . . . . . . . . . 3-50

3.5.9 Decommissioning of the ANL Research Reactors . . . . . . . 3-51

3.5.10 Decommissioning of the ZGS . . . . . . . . . . . . . . 3-51

3.5.11 Impact of Onsite Fallow Deer . . . . . . . . . . . . . . 3-52

3.6 Economic and Sociocultural Impacts .............. . 3-53

3.6.1 Economic Impacts . . . . ... . . . . . . . . . . . 3-53

3.6.2 Sociocultural Impacts .................. . 3-53

3.7 Special Nuclear Materials Safeguards and Security . . . . . . . 3-54

References (Section 3)................... . . 3-56

4. UNAVOIDABLE ADVERSE ENVIRONMENTAL IMPACTS . . . . . . . . . . . . . 4-1 
5. ALTERNATIVES . . . . . . . . . . . . . . . . . . . . . 5-1

5.1 Termination and Abandonment . . . . . . . . . . . . . . . . . 5-1

5.1.1 Termination Without Resumption Elsewhere . . . . . . . . 5-1

5.1.2 Termination With Resumption Elsewhere .......... . . 5-2

5.2 Partial Termination of Operations . . . . . . . . . . . . . 5-3

5.3 Limitation of Environmental Impacts . . . . . . . . . . . . . 5-3

6. RELATIONSHIP BETWEEN SHORT-TERM USE AND LONG-TERM

PRODUCTIVITY . . . . . . . . . . . . . . . . . . . . . . 6-1

7. RELATIONSHIP OF CONTINUED OPERATION TO LAND-USE PLANS,

POLICIES, AND CONTROLS . . . . . . . . . . . . . . . . . . . . 7-1

References (Section 7) .................... . . 7-2

8. IRREVERSIBLE AND IRRETRIEVABLE COMMITMENTS OF RESOURCES . . . . . . 8-1

9. IIST OF PREPARERS . . . . . . . . . . . . . . . . . . . . . 9-1

10. AGENCIES CONSULTED . . . . . . . . . . . . . . . . . . . . . 10-1

APPENDIX A. LIST OF ABBREVIATIONS . . . . . . . . . . . . . . . . . . . A-1

APPENDIX B. ATMOSPHERIC DISPERSION AND DOSE MODELS . . . . . . . . . . . B-1

B.1 Atmospheric Dispersion Model . . . . . . . . . . . . . . . . B-1

B.2 Inhalation Model ..................... . B-2

B.3 Dose Model . . . . . . . . . . . . . . . . . . . . . . . . . . B-2

References (Appendix B) . . . . . . . . . . . . . . . . . . B-9

APPENDIX C. MANAGEMENT PLAN FOR THE ONSITE FALLOW DEER POPULATION . . . C-1

C.1 Introduction . . . . . . . . . . . . . . . . . . . . . . . . . . C-1

C.2 Background . . . . . . . . . . . . . . . . . . . . . . . . . c-1

C.2.1 Taxonomy and Distribution................. . C-1

C.2.2 History . . . . . . . . . . . . . . . . . . . . . C-2

C.3 Aspects of Fallow Deer Ecology . . . . . . . . . . . . . . . . . C-3

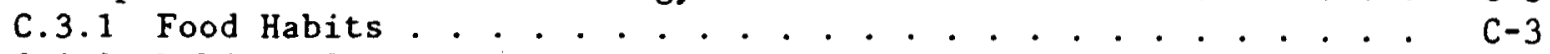

C.3.2 Habitat Requirements . . . . . . . . . . . . . . . . . C-3

C.3.3 Population Dynamics... . . . . . . . . . . . . . . C-4

C.3.4 Competition....................... . . C-4

C.3.5 Human Interactions . . . . . . . . . . . . . . . . c-5

C.4 Management Strategy . . . . . . . . . . . . . . . . . . C-6

References (Appendix C) . . . . . . . . . . . . . . . . c-6

APPENDIX D. TABLE OF METRIC/ENGLISH EQUIVALENTS . . . . . . . . . . . . D-1 


\section{FIGURES}

Figure

Argonne National Laboratory Organization Chart . . . . . . . 2-3

2.2

2.3

2.4

2.5

2.6

2.7

2.8

Argonne National Laboratory Perspective View . . . . . . . . . 2-6

General View of Argonne Thermal Source Reactor Facility . . . . 2-8

Cutaway View of Argonne Thermal Source Reactor . . . . . . . . . 2-9

JANUS Reactor Configuration . . . . . . . . . . . . . . . . . . 2-11

ZPR-6 Facility . . . . . . . . . . . . . . . . . . . . . . 2-13

Flow Chart for ANL Radioactive Waste Handling . . . . . . . . . 2-21

ANL Site Plan Showing Locations of Sanitary Landfill, Boiler Plant, and Coal Storage Pile . . . . . . . . . . . 2-25

2.9 Map of Regional Area . . . . . . . . . . . . . . . . . . . . . . 2-29

2.10 Area Around ANL Site Showing Radii of $16,32,48$, 64 , and 80 Kilometers ... . . . . . . . . . . . . . 2-30

2.1 ANL Site Plan Showing Location of Sampling Stations . . . . . . 2-31

2.12 Monitoring-Station Locations Surrounding ANL . . . . . . . . . . 2-39

2.13 Area Surveyed From 1978 Through 1981 by Shovel Testing . . . . . 2-46

3.1 Schematic Diagram Showing Typical Laboratory Waste-

3.2 Radiation Exposure to Monitored Personnel at ANL, 1974-1980 . . . . . . . . . . . . . . . . . . . . . . 3-19

3.3 ANL Windspeed Risk Curve . . . . . . . . . . . . . . . . . . 3-40 



\section{TABLES}

Table

2.1

2.2

2.3

2.4

2.5

2.6

2.7

$2.8 \mathrm{SO}_{2}$ Data from Continuous Monitors Within an Approximate

Facilities with Potential for Environmental Impact. . . . . . 2-5

JANUS Reactor Characteristics . . . . . . . . . . . . . 2-10

1978 Estimated Population Distribution . . . . . . . . . . . 2-35

Monthly Mean and Extreme Temperatures at Midway Airport . . . . 2-37

Mean and Extreme Precipitation at Midway Airport, 1941-1970 . . 2-38

Summary of National and Illinois Ambient Air Quality

Standards . . . . . . . . . . . . . . . . . . . . . . 2-40

.7 TSP Data from Monitors Located Within an Approximate $16-\mathrm{km}$

Radius of Argonne National Laboratory . . . . . . . . . . . . . 2-41

16-km Radius of Argonne National Laboratory. . . . . . . . . . . 2-42

2.9 Birds Commonly Observed on the ANL Site . . . . . . . . . . . . 2-48

2.10 Mammals Commonly Observed or Likely to Occur on the ANL Site . . 2-49

2.11 Reptiles and Amphibians Commonly Observed or Likely

to Occur on the ANL Site . . . . . . . . . . . . . . . . . . . 2-49

2.12 Aquatic and Marsh Macrophytes of ANL . . . . . . . . . . . . . . 2-51

2.13 Composition and Abundance of Algae in the Plankton

of ANL Habitats . . . . . . . . . . . . . . . . . . . . . . . . 2-52

2.14 Algae Identified from the Periphyton in Sawmill Creek

Aquatic Habitats, September 20, 1978 . . . . . . . . . . . . 2-54

2.15 Macroinvertebrate Species Collected from Sawmill Creek,

September 20,1978 . . . . . . . . . . . . . . . 2-56

2.16 Fish in ANL Aquatic Habitats . . . . . . . . . . . . . . . . . 2-57

2.17 Endangered Plant Species in Illinois That Occur (or

Probably Occur) in More Than One County Adjacent to

Argonne National Laboratory . . . . . . . . . . . . . . . 2-59

2.18 Threatened Plant Species in Illinois That Occur (or

Probably Occur) in More Than One County Adjacent to

Argonne National Laboratory . . . . . . . . . . . . . 2-60

2.19 Chemical Constituents in ANL Effluents and Sampled Water . . . . 2-63

3.1 Major Constituents in Effluent from ANL Treatment

Plant, 1980 . . . . . . . . . . . . . . . . . . . . 3-5

3.2 Trace Constituents in Effluent from ANL Treatment

Plant, 1980 . . . . . . . . . . . . . . . . . . . . . . . 3-6

3.3 Effect of Sanitary Waste on Sawmill Creek in 1980 . . . . . . . 3-8

3.4 Chemical Constituents in Sawmill Creek, Location 7M, 1980 . . . 3-9

3.5 Atmospheric Releases of Radioactivity, 1980 . . . . . . . . . . 3-12

3.6 Whole-Body Dose from Airborne Emissions, 1980 . . . . . . . . . 3-15

3.7 Whole-Body Population Dose Within $80 \mathrm{~km}$. . . . . . . . . . . 3-15

3.8 Releases of Radioactivity to Sawmill Creek, 1980 . . . . . . . . 3-17

3.9 Radionuclide Concentrations and Dose Estimates for

Sawmill Creek Water, 1980 . . . . . . . . . . . . . . . . . 3-17

3.10 Lifetime Dose Commitment Following NBL Glovebox Explosion . . . 3-26

3.11 Lifetime Dose Commitment Following MSD Glovebox Explosion . . . 3-27 
TABLES

$\underline{\text { Table }}$

Page

3.12

Lifetime Dose Commitment Following a Uranium FIre . . . . . . . 3-28

3.13

Lifetime Dose Commitment Following a Plutonium Fire . . . . . . 3-29

3.14

Vital Facilities and Windspeed Damage Threshold . . . . . . . . 3-38

3.15

Ground-Level Concentrations Following Tornado Dispersion

for a Release of One Unit of Material . . . . . . . . . . . . 3-42

3.16

Probability of Exceeding Threshold Windspeed . . . . . . . . . . $3-43$

3.17

Material at Risk During Tornado Strike . . . . . . . . . . . . . 3-44
Plutonium Dose Commitment Following Tornado Strike . . . . . . $3-46$

3.18

Plutonium Dose Commitment Following Tornado Strike . . . . . . . . 3-46
Summary of Significant Accident Analysis Results . . . . . . . $3-47$

3.19

Summary of Significant Accident Analysis Results . . . . . . . . . . . $3-47$
Radioisotopes Used in Ecology Experiments . . . . . . . . . . . . $3-49$

3.20

Security Requirements for Special Nuclear Materials

3.21

Facilities . . . . . . . . . . . . . . . . . . 3-55

4.1 Unavoidable Adverse Impacts of Argonne Operations . . . . . . . 4-2

B. 1

Lifetime Adult Organ Dose Commitment Due to Inhalation

of $1 \mu \mathrm{Ci}$ of Nuclide ..................... . B-4

B.2 Adult Organ Dose Rate Due to Deposition of $1 \mu \mathrm{C} i$ of Nuclide . . B-6

B.3 Fraction of Inhaled Material Deposited in Reference Organ, f . . B-7

B.4 Continuous Release Dose Commitment Factor, $F\left(d^{2}\right)$. . . . . . . B-7

B.5 Dose Commitment Ratio, DCR . . . . . . . . . . . . . . . B-8

C.1 Census of Fallow Deer .. . . . . . . . . . . . . . . . . C-2 


\section{SUMMARY}

In order to evaluate the environmental impacts of Argonne National Laboratory (ANL) operations, this assessment includes a descriptive section--Section 2, Background--which is intended to provide sufficient detail to allow the various impacts to be viewed in proper perspective. In particular, details are provided on site characteristics, current programs, characterization of the existing site environment, and in-place environmental monitoring programs. In addition, specific facilities and operations that could conceivably impact the environment are described at length.

In Section 3, Environmental Impact, routine and accidental releases of nonradioactive and radioactive materials are described and analyzed. Some of the results of routine releases are as follows:

(a) Nonradioactive

1. Calculated offsite concentrations of particulates, $\mathrm{NOx}$, and $\mathrm{SO}_{2}$ from ANL operations are a fraction of the applicable state standards. Offsite concentrations are within normal ambient levels at distances greater than $5 \mathrm{~km}$ from ANL (Section 3.1.2.1.1).

2. Discharges of certain pollutants to Sawmill Creek may occasionally exceed applicable standards. No adverse effects of ANL operations on Sawmill Creek or on the receiving body, the Des Plaines River, have been reported (Section 3.1.2.1.2).

\section{(b) Radioactive}

1. An adult continuously outside the residence having the highest concentration of radiation related to the atmosphere from ANL would receive a calculated whole-body dose of $<0.001 \mathrm{mrem} / \mathrm{yr}$. The natural background dose rate is $92 \mathrm{mrem} / \mathrm{yr}$. The total maximum population dose from ANL is < 0.1 person-rem/yr within an $80-\mathrm{km}$ radius, compared with the natural background dose of 730,000 person-rem/yr (Section 3.1.2.2.1).

2. Plutonium-239 released to the atmosphere from ANL is insignificant compared with that from weapons-test fallout (Section 3.1.2.2.1).

3. Radionuclides released to Sawmill Creek have average concentrations less than one percent of applicable standards (Section 3.1.2.2.2).

4. The highest individual dose rate attributable to cobalt -60 irradiations in Bldg. 202 is $<0.1 \mathrm{mrem} / \mathrm{yr}$ at the nearest residence (Section 3.1.2.2.4). 
A detailed survey of credible accidents is presented in Section 3.4 . Some of the resulting releases are summarized below:

\section{(a) Nonradioactive}

The major nonradioactive hazard is the accidental release of chlorine used for water and sewage treatment. The calculated chlorine concentration at the nearest residence from such a release is $0.5 \mathrm{mg} / \mathrm{m}^{3}$ which is well below dangerous concentrations (Section 3.4.3.4.1).

\section{(b) Radioactive}

1. The largest calculated 50-yr dose commitment at the site boundary due to an explosion in a plutonium glovebox is $1.2 \mathrm{mrem}$ to the bone (Section 3.4.3.1.1).

2. The largest calculated 50-yr dose commitment at the site boundary due to a fire in a plutonium storage vault is less than 0.002 mrem to the bone (Section 3.4.3.2.2).

3. A probabilistic treatment of the dispersion of plutonium following a tornado strike results in a maximum calculated individual 50-yr dose commitment to the bone of the nearest resident of $200 \mathrm{mrem}$, and a corresponding population dose commitment of about 49,500 person-rem within $80 \mathrm{~km}$ (Section $3 \cdot 4 \cdot 3 \cdot 5 \cdot 3$ ).

Other impacts discussed are:

(a) Land Usage

Current usage of land by ANL is in harmony with local land-use plans (Sections $3.2 .1,4,6,7$, and 8 ).

\section{(b) Water Usage}

1. ANL potable water consumption does not affect offsite piezometric levels (Section 3.2.2).

2. Process cooling water withdrawn from the Chicago Sanitary and Ship Canal is an infinitesimal fraction of the canal flow (Sections 3.2 .2 and 4.0 ).

\section{(c) Energy Usage}

The consumption of energy in the forms of natural gas, oil products, coal, and electricity is a small fraction of similar consumptions by other users in the area (Sections 3.2 .3 and 4 ).

It is concluded that the anticipated long-term benefits of the DOE programs can be realized with relatively inconsequential environmental impacts. 


\section{PROPOSED ACTION AND ITS ALTERNATIVES}

\subsection{PROPOSED ACTION}

The proposed action covered by this Environmental Assessment (EA) is the continued operation of Argonne National Laboratory (ANL) as a federal, contractor-operated research and development facility with programs designed to apply broad-based scientific and technological resources to the solution of problems related to the supply and utilization of energy and to the protection of the environment. Although this EA primarily covers current operation of ANL, it should be noted that the orientation of both individual and collective research and development programs has historically evolved in response to national needs. It is anticipated that this dynamic mode of operation will continue but that the programs and facilities (and their attendant effects) described in this document will be representative of those expected in the foreseeable future. Current operations are described in Section 2.1.

\subsection{ALTERNATIVES CONSIDERED}

Alternatives to the continued operation of ANL at the present site are evaluated in Sections 5.1 and 5.2. The alternatives considered are: total abandonment of the site and work, total or partial transfer of the work to other areas and institutions, and modification of current operations without essentially changing the orientation of the programs. 


\section{BACKGROUND}

In order to consider the environmental impacts of Argonne National Laboratory (ANL) operations, it is necessary to first review its history, organization, and current programs. These, as well as a characterization of the existing environment, are the subjects of this section.

As one of three U.S. Department of Energy (DOE) multidisciplinary laboratories, Argonne is engaged in a multitude of program areas in both the basic and applied sciences. The following subsections provide background information to place the environmental impacts of ANL operations, covered in Section 3 , in perspective. In this assessment, the total ANL operation--consisting of both contractor- and government-operated facilities--is referred to simply as ANL.

\section{I DETAILED DESCRIPTION OF ANL}

\subsubsection{Site History}

Argonne National Laboratory is an outgrowth of the Metallurgical Laboratory which was established in 1942 as part of the Manhattan Project. The "Met Lab" comprised a dozen or more buildings on The University of Chicago campus and several buildings in the Argonne Forest area of the Palos Park Forest Preserve. At the Argonne Forest site, two research reactors were housed. The first was Chicago Pile No. 2, the graphite-moderated reactor with which the first self-sustained, controlled nuclear chain reaction was demonstrated; this reactor had been moved from The University of Chicago campus and reconstructed at the Argonne Forest site. The second reactor was the heavy-water-moderated Chicago Pile No. 3.

On April 19, 1946, the Manhattan Engineer District offered The University of Chicago a letter contract for the continued operation of the Metallurgical Laboratory, which, on July 1, 1946, was established as a permanent laboratory and renamed Argonne National Laboratory. During 1951-1953, ANL moved from the Palos Park Forest Preserve to its present site in DuPage County at Argonne, Illinois. As originally conceived, the primary responsibility of the Laboratory was that of basic research in the many areas of science pertinent to the development of nuclear energy. However, on January 1, 1947, the U.S. Atomic Energy Commission assigned the Laboratory major responsibilities in the field of reactor development in addition to the research activities in which it was already engaged. This two-fold responsibility of basic research on the one hand and applied research on the other has continued to the present.

\subsubsection{Administrative Structure}

Argonne National Laboratory is operated under a tripartite contract between the U.S. Department of Energy (DOE), The University of Chicago, and the Argonne Universities Association (AUA), a consortium of 30 Midwest 
universities. The University of Chicago operates the Laboratory for DOE in accordance with the policies and programs established jointly with the AUA.

ANL is a multiprogram laboratory with multidisciplinary research, development, and demonstration (RD\&D) programs in five major scientific and technical areas: physical science; high energy physics; biomedical and environmental sciences; energy and environment; and engineering science. Since many programs and projects cut across disciplinary lines, ANL has adopted a matrix-type organizational structure in which the scientific and engineering manpower is administratively tied to a discipline-oriented division and assigned, as needed, to specific projects and programs. The R\&D programs are supported by many service organizations. The administrative structure of ANL is shown in Figure 2.1. ANL currently (November 1981) employs about 4500 persons, of whom over 4300 are permanent employees. Temporary employees include students, visiting faculty and industry scientists, and postdoctoral appointees.

\subsubsection{Research and Development Activities}

ANL carries out broad programs of fundamental and applied research in the physical, biomedical, and environmental sciences and serves as a major center for energy research and development. Research and development work has concentrated primarily on long-term, high-risk technologies and problems that industry on its own could not reasonably be expected to undertake. Although reactor development, primarily of the fast breeder reactor concept, is still the largest energy program at Argonne, involvement in new initiatives has been strongly accelerated in the last few years. These include research and development programs in fossil energy, conservation, and solar energy, as well as environmental programs, systems studies, and policy evaluations. Several major ANL programs--some with experimental facilities--have been set up to operate in a national user mode whereby ANL actively encourages and supports university and industry use. Additionally, ANL houses and supports numerous educational programs.

The physical science program encompasses research in physics, chemistry, mathematics, materials, and solid state science. The high energy physics program centers around the Laboratory's particle accelerators used to study elementary atomic particles and their interactions. Argonne's low energy physics program includes studies in nuclear physics, atomic physics, and nonnuclear areas. Major areas of investigation are heavy-ion reactions, fission theory, and nuclear matter, structure, and forces.

Basic chemical investigations include major programs devoted to studying energy conversion and storage, physical and surface chemistry of energy systems, chemical behavior at very high and very low temperatures, atomic and molecular energy transfer, molecular structure using $X$-ray and neutron diffraction, and chemistry of the heavy elements and the nucleus.

Mathematical research and computer development includes numerical mathematics studies, computer studies, and the operation of a central computer facility and the National Energy Software Center.

Argonne's materials science research includes studies of the physical properties and electronic structure of metals, alloys, and intermetallic compounds; irradiation studies; nondestructive testing; fabrication technology 


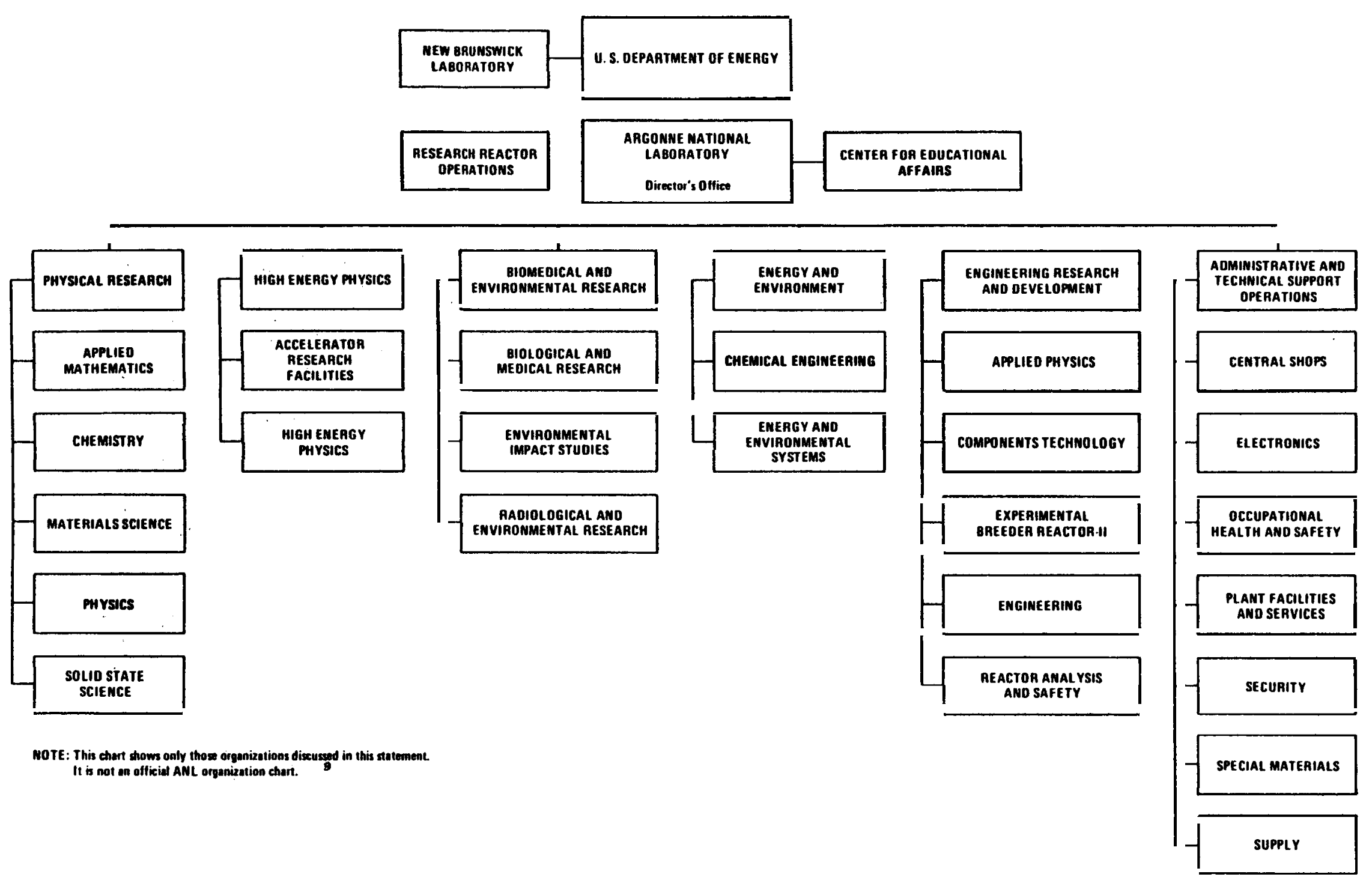

Figure 2.1. Argonne National Laboratory Organization Chart. 
development; the development of computer models of physical processes and systems; neutron scattering research on the structure and dynamic properties of condensed matter; and studies of radiation damage processes.

Biomedical and environmental research at Argonne is designed to assess the impacts of pollutants from all forms of energy generation on biological and environmental systems. Radiobiological studies, using laboratory animals exposed to cobalt-60 gamma rays or neutrons from the JANUS biological research reactor, have been underway for years. Recently, a study has been initiated to determine the effects on laboratory mice of exposure to gaseous effluents from fluidized-bed combustion of high-sulfur coal.

Other biomedical programs include the development of medical diagnostic procedures and treatments, the use of stable isotopes in diagnosing a variety of diseases, and improved therapies for metal poisoning.

Argonne's Center for Human Radiobiology is engaged in a long-term study of all individuals in the United States with radium body burdens. Recently, the Center also began a study of former employees of a thorium-processing plant.

Environmental concerns have been part of Argonne's research since the Laboratory's inception. Argonne's environmental research has helped create accurate systems models for determining the sources and movements of effluents and their probable effects on populations. These models are being applied to the control of air and water pollution. In addition, environmental problems confronting the Great Lakes, such as thermal discharges from nuclear power plants, are under intensive study, as are the environmental aspects of coal mining.

Research on the fast breeder reactor concept includes major programs on fast reactor physics, fast reactor safety, fuels and materials development, and components technology development. Argonne currently operates three research reactors at the Illinois site, including a fast reactor critical assembly large enough to permit mockups of very large breeder reactor cores.

In addition to reactor research and development, alternate energy sources under study at Argonne include concentrating solar collectors, fluidized-bed coal combustion, advanced battery concepts, magnetohydrodynamics, ocean thermal gradient heat exchangers, magnetic confinement fusion reactors, and a new program to develop heavy-ion beam pellet fusion.

A more detailed description of ANL R\&D Divisions and programs (and related support facilities) is found in recent ANL publications (Argonne Univ. Assoc. 1982; Argonne Nat1. Lab. 1980b).

Any radioactive wastes generated by these programs are held for a limited period of time before being shipped offsite for permanent burial.

\subsubsection{Description of Current Facilities}

The ANL installation contains a wide variety of facilities and equipment that serve numerous and diverse operational purposes. As a practical matter, it is impossible to describe all facilities and list all equipment items, most 
of which are conventional and routinely used in most research institutions. Furthermore, in most cases, the environment beyond the site boundary cannot be adversely affected by the operation (routine or abnormal) of such equipment.

This section describes those ANL facilities and operations which either have, or could reasonably be expected to have some measurable impact on the environment. Thus, the facilities described are those that are subsequently discussed in the analysis of the environmental impacts in Sections 3.1 and 3.4. Table 2.1 is a list of all such equipment and operations. Building locations are shown in Figure 2.2.

Table 2.1. Facilities with Potential for Environmental Impact

\begin{tabular}{ll}
\hline Name of Facility & Operating Organization(s) \\
\hline ATSR & AP \\
JANUS & JRO \\
ZPR-6 and -9 & AP \\
AGHCF & MSD \\
Bldg. 310 Experiment Assembly Facility & EBR-II, RAS \\
Bldg. 200, Wing M & CHM \\
Bldg. 212, Special Facility FD12 & MSD \\
Bldg. 350, Plutonium Areas & NBL, ANL (various) \\
Gammabeam-650 Cobalt-60 Irradiator & BIM \\
SNM Vaults & SPM, NBL \\
Boiler Plant & PFS \\
Water Supply System & PFS , \\
Waste Handling Facilities & PFS \\
\hline
\end{tabular}

${ }^{a}$ See Appendix A for list of abbreviations.

\subsubsection{Argonne Thermal Source Reactor}

The Argonne Thermal Source Reactor (ATSR), located in B1dg. 316, was designed and initially operated in 1953 as a source of fast neutrons for unmoderated exponential experiments. In 1957, it was modified and relocated to serve as a readily accessible source of neutrons for experimental purposes. 


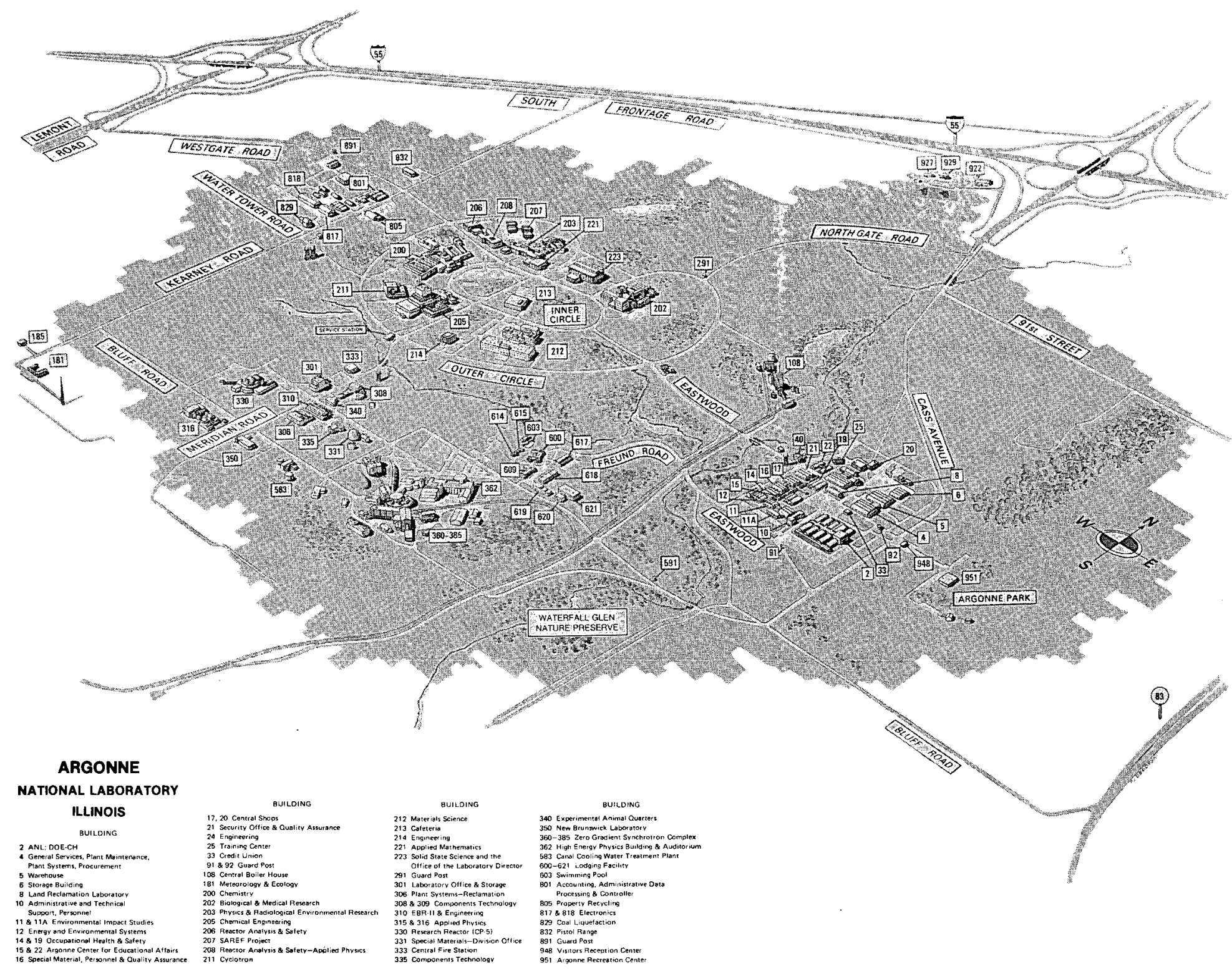

Figure 2.2. Argonne National Laboratory Perspective View. 
It has had a continuing role as a flexible experimental facility. It is used as a sample irradiation facility, as a precise reactivity measurement device for samples inserted in a central thimble, and as a source of large quantities of thermal or fast neutrons for the measurement of reactor physics parameters and for the testing of neutron detectors.

Figure 2.3 is a schematic view of the principal components of the ATSR facility. These include the reactor, control console, personnel shielding, experimental cell, and exclusion fence. The reactor instruments and controls are located on a single, multisectional console in a control room. There is also enough additional space in the control room to accommodate experiment equipment. The reactor is located in an adjacent cell, which is separated from the control room by a $0.91-\mathrm{m}$-thick concrete and masonry wall. The reactor shield and dump tanks and control rod drive units are visible just beyond that wall.

Figure 2.4 shows a cutaway view of the reactor, which consists principally of Boiling Reactor Experiment (Borax) type fuel elements, three tanks and related plumbing, lead shielding, and control rod units.

Fuel assemblies consist of ten curved, aluminum-clad, uranium-aluminum alloy plates welded to or inserted in grooves within aluminum side plates. Each 10-plate element contains $0.157 \mathrm{~kg}$ of uranium-235. The critical mass is approximately $3 \mathrm{~kg}$ of uranium-235.

The cell that contains the ATSR is essentially a confinement rather than a containment structure. During normal reactor operation, heating or cooling is provided by units in the cell, with the air simply recirculated throughout the cell. There is also an exhaust fan to exhaust air from the cell to the outside. The same exhaust $f a n$ is part of the emergency exhaust system. During operation of this system, the exhausted air is passed through highefficiency particulate air (HEPA) filters, which remove at least $95 \%$ of particulate radionuclides.

Because the ATSR is used primarily as a source of neutrons or as a means for determining reactivity effects, changes in the core loading are made only infrequently. The fuel loading is adjusted so that no more than $0.5 \%$ reactivity is available to the operator.

The ATSR may be operated at sustained power levels up to $10 \mathrm{~kW}$. However, due to radiation safety considerations, operations have been administratively limited to approximately $30 \mathrm{kWh}$ per week. In actual practice, the ATSR is now operated approximately 200 hours per year at an average power level of $100 \mathrm{~W}$, or about $20 \mathrm{kWh}$ per year.

Core water is stored in a dump tank below ground level. During startup the water is pumped into the core; at shutdown it is returned to the dump tank. The water is pumped continuously through a purification system whether or not the reactor is operating. The purification system consists of a pair of filters and an ion-exchange column. The purity of the water is monitored by measuring its resistivity.

The water in the shield tank has its own purification system, independent of the core water. This water is also circulated through filters and an 




Figure 2.3. General View of Argonne Thermal Source Reactor Facility. 


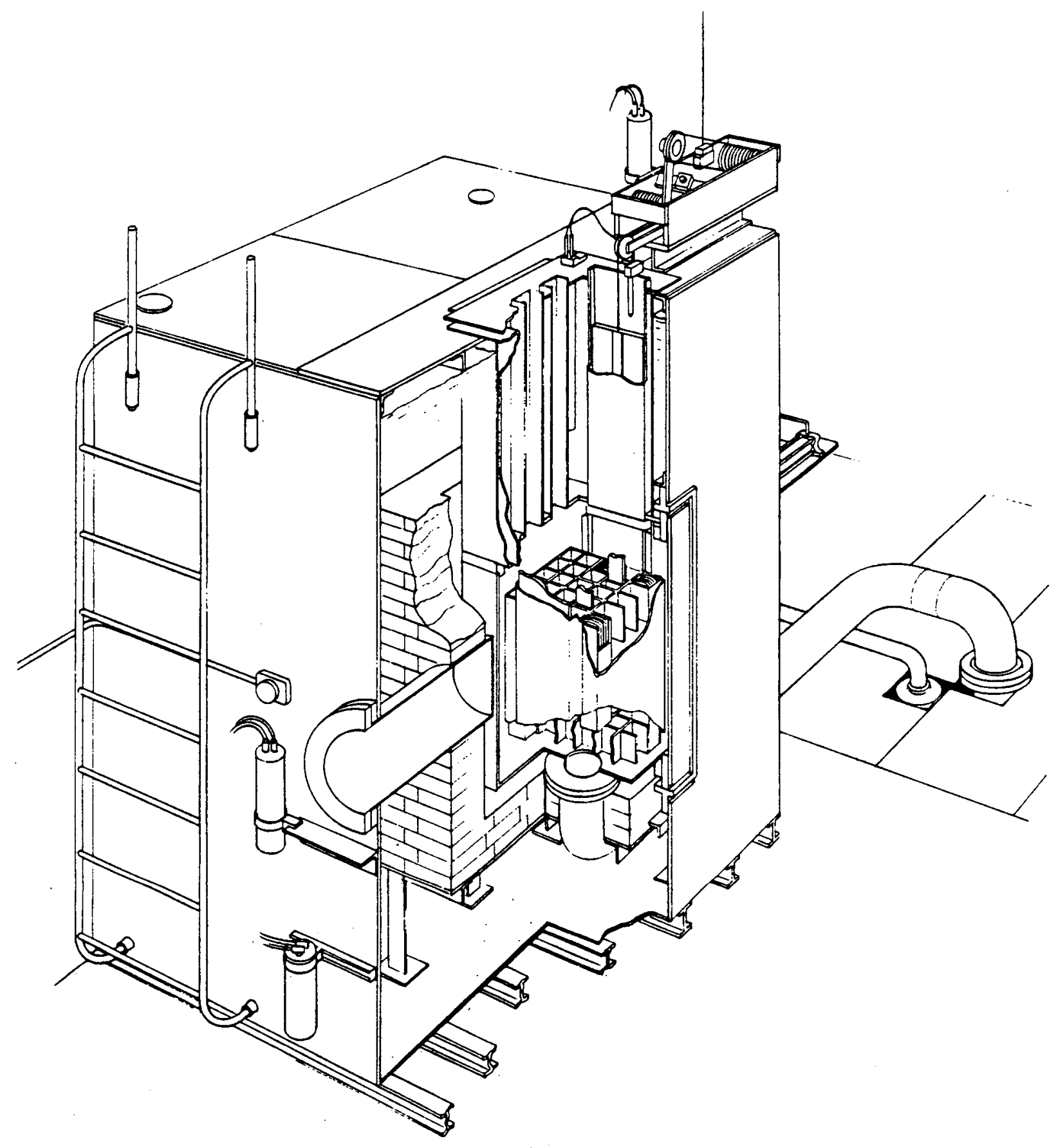

Figure 2.4. Cutaway View of Argonne Thermal Source Reactor. 
ion-exchange column to maintain high-resistivity water in order to minimize corrosion.

The only effluents from the ATSR are the core and shield waters which are replaced every year during the annual preventive maintenance period. In general, the water is of sufficient purity that it may be disposed by discharge to the sewer system. In the event that radiation levels do not permit disposal in this manner, the water is placed in drums and transferred to Plant Facilities and Services-Waste Management Operations (PFS-WMO) for disposal.

\subsubsection{JANUS Reactor}

The JANUS reactor has been designed for animal radiation studies at the Biological and Medical Research Division (BIM). The characteristics of the reactor are listed in Table 2.2 and the configuration is shown in Figure 2.5. Two neutron fluxes are produced on opposite sides of the reactor. The offcenter location of the core allows a neutron flux on the near side that is $10^{4}$ times greater than on the far side. The energy of the neutrons can be regulated by the graphite zone.

Table 2.2. JANUS Reactor Characteristics

\begin{tabular}{lc}
\hline Fuel & $\mathrm{U}-235$ \\
Tubular fuel assemblies & 19 \\
Thermal power rating, $\mathrm{kW}$ & 200 \\
Nominal critical mass, $\mathrm{kg}$ of uranium-235 & 2.5 \\
Primary coolant/moderator & $\frac{\mathrm{H}_{2} \mathrm{O}}{\mathrm{A} 1}$ \\
Normal coolant flow rate, $\mathrm{m}^{3} / \mathrm{s}$ & 0.0063 \\
Normal coolant inlet temperature, ${ }^{\circ} \mathrm{C}$ & 30 \\
\hline
\end{tabular}

The reactor is controlled from the ground floor control room, and on the same level there is an area above the reactor for maintenance and refueling. Adjacent to the reactor are high-level and low-level dose rooms for specimen irradiation. The dosages are monitored from the preparation rooms located next to the dose rooms.

The equipment for the primary and secondary circulation systems and for the helium blanket system is located in the equipment room. An evaporative cooling tower is used to cool the secondary system water. Exhaust air is passed through High Efficiency Particulate Air (HEPA) filters before release. 


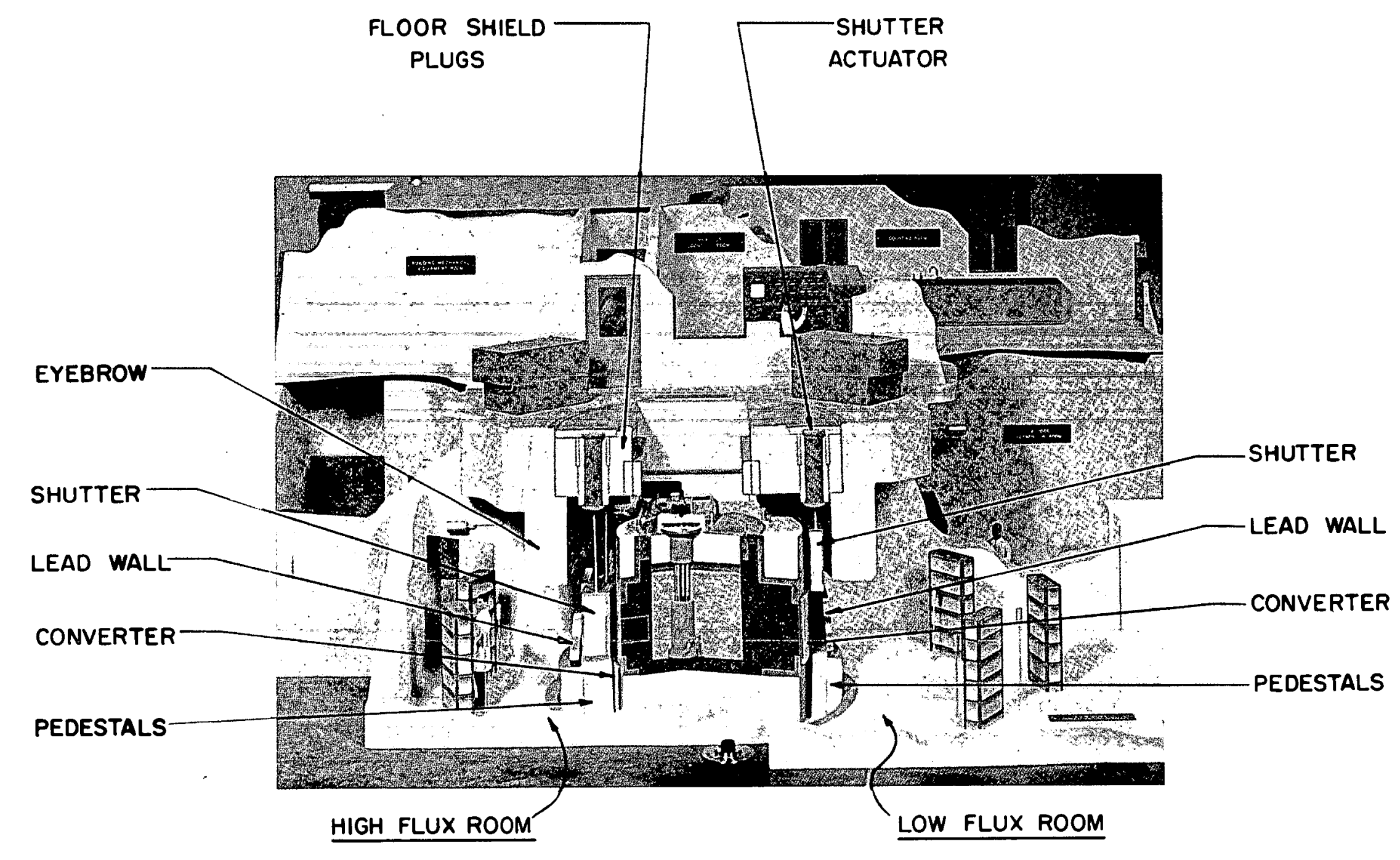

Figure 2.5. JANUS Reactor Configuration. 


\subsubsection{2PR-6 and ZPR-9}

ANL operates two flexible, low-power experimental reactor facilities in Bldg. 316. These are used for reactor physics measurements in support of reactor design programs. They are essentially identical systems (except for the maximum size of the assembly that may be built) and are representative of a class of reactor test facilities known as critical assemblies or Zero Power Reactors (ZPRs).

Restriction of the operating power level of the ZPRs to usually well below $1,000 \mathrm{~W}$ obviates the need for a heat removal and dissipation system and results in an extremely low level of residual radioactivity. Normal operation at ambient temperature results in very modest demands on the properties of the materials used in the systems. Facilities include a steel confinement shell around the concrete cells housing the reactors, air cooling and ventilation systems, and additional monitoring and safety equipment.

The ZPR-9 facility is a split-table type critical assembly consisting of one stationary and one movable table, as shown in Figure 2.6. The two tables are $3.7-\mathrm{m}$ wide and $2.4-\mathrm{m}$ long and rest on a cast steel bed. Each of the tables is designed to carry approximately 80 metric tons (MT). On each table is stacked horizontally a 45 row by 45 column array of $5.5-\mathrm{cm}-$ square stainless steel tubing $1.2-\mathrm{m}$ long, forming half of a $2.4-\mathrm{m}$ cube reactor. Fissionable material such as enriched uranium and plutonium, and other materials such as depleted uranium, stainless steel, aluminum, zirconium, sodium, graphite, and the oxides of heavy metals are inserted into the simulated cores to test various reactor compositions. ZPR- 6 is essentially identical except it contains a larger tube matrix that allows an assembly of $3.5 \times 3.5 \times 2.4 \mathrm{~m}$ to be built.

To initiate reactor operation, the movable table is driven toward the stationary table by electric motors. A separate electric motor, backed up by an air motor, is used to rapidly separate the tables when a shutdown signal is received.

Each half of the reactors has both safety and control/safety (dual purpose) rods for changing the reactivity of the system. The reactors are located in individual blast-resistant, steel-reinforced concrete cells. Exhaust air is passed through a double bank of HEPA filters to remove particulate radionuclides and is released via a $46-\mathrm{m}$ stack.

\subsubsection{Alpha-Gamma Hot Cell Facility}

The Alpha-Gamma Hot Cell Facility (AGHCF) operated by the Materials Science Division (MSD) in Bldg. 212 consists of a concrete-shielded, low-flow inert-atmosphere complex that was designed for the examination of irradiated plutonium fuel assemblies and related hardware. The containment system is sufficiently leaktight to maintain an inert nitrogen atmosphere under negative pressure. It is, therefore, an adequate containment system for particulate plutonium.

The nitrogen supply system is the only direct connection to a piped building utility. Because of the criticality hazards control considerations, no hydrogenous fluids are piped into or recirculated within the shielded 


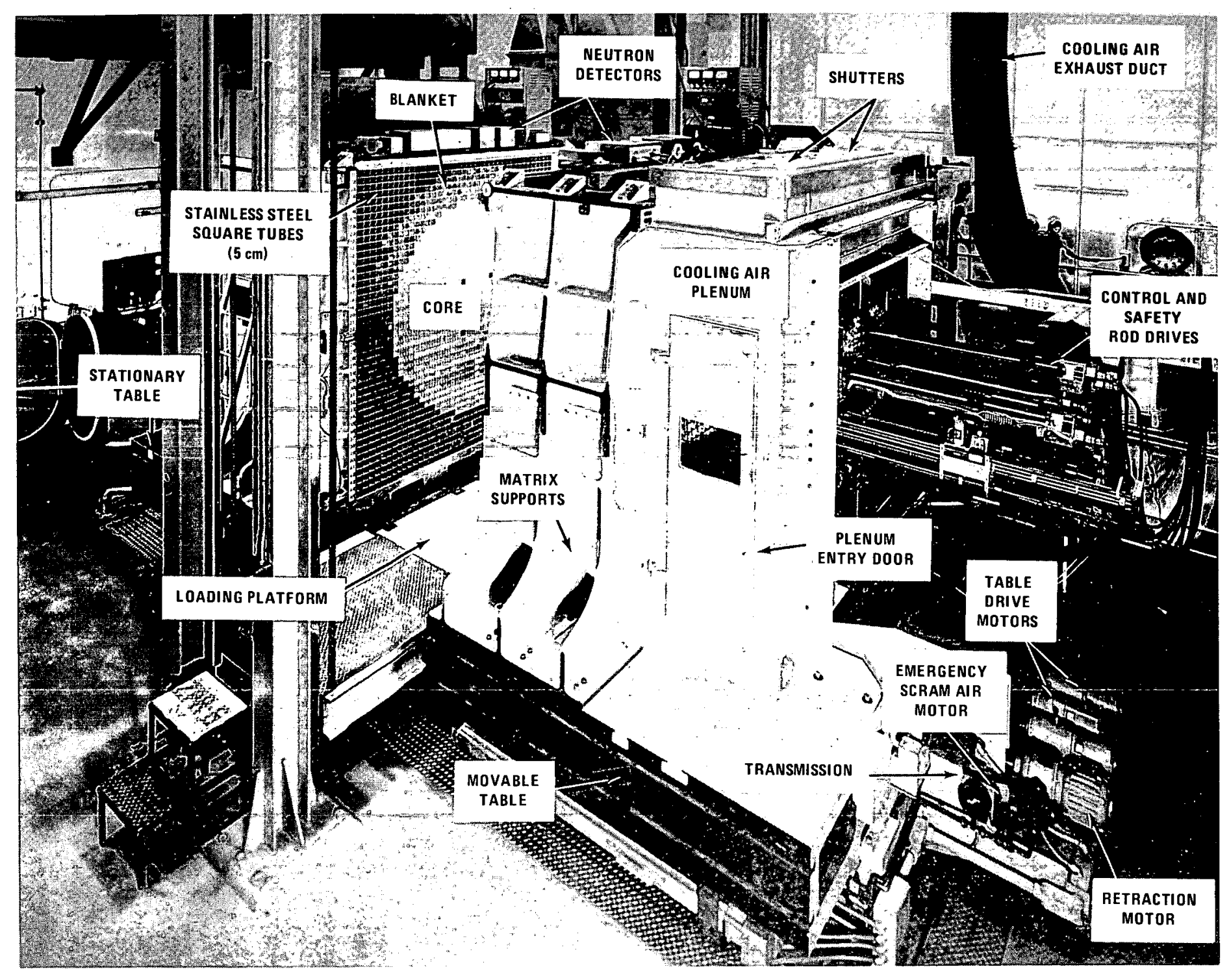

Figure 2.6. ZPR-6 Facility. 
facility. Heat removal from the cells is accomplished by convection to the nitrogen gas flow and conduction through the cell walls.

Radioactive wastes and debris are transferred to PFS-WMO. The only other effluent from the hot cell is the nitrogen atmosphere exhaust. Nitrogen is exhausted at a flow rate between 2.8 and $9.4 \mathrm{~L} / \mathrm{s}$ on a continuous basis. This exhaust passes through two HEPA filter banks and activated carbon and is then mixed with air when discharged to the atmosphere.

The fissile material inventory is limited by the provisions of approved criticality hazards control documents. The actual amount of fissile material present is somewhat less than the allowable amount. In addition to the fissile material, the cell contains radioactive cladding and other structural materials.

The hot cell is centrally located within the building and is separated from the external environment by two interior concrete block walls and one exterior concrete block wall that afford a high degree of protection against tornadoes.

\subsubsection{Bldg. 310 Experiment Assembly Facility}

In-pile plutonium-fueled experiments for the Reactor Analysis and Safety Division (RAS) safety programs are assembled in a special area of Bldg. 310 . These experiments utilize a number of fuel elements and instruments which are assembled into a test train. The test train is then shipped elsewhere for insertion into the in-pile test hardware.

As an example of the magnitude of the Bldg. 310 operations, the Sodium Loop Safety Facility (SLSF) P4 test train consisted of a number of fully encapsulated unirradiated fuel elements containing a total of $3,473 \mathrm{~g}$ of uranium-235 and $1,415 \mathrm{~g}$ of fissile plutonium. In future SLSF tests, the total weight of fuel in a test train is expected to remain constant, but the uranium-235 content may vary based on experiment requirements. The test train assembly work is done in conformance with an approved standard specification. This document is being revised to permit the assembly of two test trains simultaneously, and therefore the amount of fuel for SLSF operations in Bldg. 310 may double'.

The fuel for the SLSF test trains is delivered to Bldg. 310 and remains encapsulated in stainless steel cladding. Equipment for the assembly operations includes helium leak detectors, welding equipment, electrical instruments, portable radiography equipment, various hand tools, assembly benches, inspection equipment, cameras, and approved storage facilities. Several SLSF test trains have been fabricated and assembled in Bldg. 310 over the past few years. This facility is used because it has the only clean area that meets appropriate standards for a controlled work area (e.g., limited access, and filtered inlet and exhaust air).

\subsubsection{Bldg. 200, Wing M}

Wing $M$ of the Chemistry Division ( $\mathrm{CHM}$ ), $\mathrm{Bldg}$. 200, is a radiochemical laboratory designed principally for separating transplutonium elements from reactor-irradiated heavy element samples containing high levels of beta-gamma activity, and for nuclear and chemical studies of these products. It contains 
a heavily shielded hot cell (cave) complex for remotely controlled operations and conventional radiochemical laboratories for further separation and study of the products (chiefly alpha-emitters).

Use of Wing $M$ for heavy element studies declined during the 1970s, although the facilities were used occasionally by various divisions. Currently (November 1981), most of the hot cells are vacant or used only occasionally. The radiochemical laboratories have remained in fairly constant use. Records have been kept of radioactive and special nuclear materials in storage, and the wing is surveyed regularly by radiation safety personnel.

The hot cell complex, at the west end of the wing, is a massive concrete structure occupying both service and main floors. It is divided into 12 individual cells, which are arranged in an $\mathrm{H}$-shaped plan with connecting transfer corridors on both levels. On the lower (service) floor, the shielding is 1.2-m thick--designed for handling megacurie sources of gamma activity. There are four megacurie cells. On the main floor, the shielding is $0.7-\mathrm{m}$ thick--designed for kilocurie levels. There are two large kilocurie cells and six smaller cells intended principally for analytical work. All cells on both floors can be isolated by sliding shielding doors.

Cell M2 contains a gamma irradiation facility for studying the effects of radiation on materials. The large (kilocurie-level) cobalt-60 source is exposed only during experiments and is adequately shielded by the cell walls.

Shielded transfer ports are provided at several locations to permit the transfer of small containers with low radiation levels out of the complex (e.g., for analytical purposes and for further study). All such transfers must be supervised by radiation safety personnel.

Ventilation of all cells is necessary because they are not hermetically sealed. Prefiltered air is drawn from the areas of lowest radioactivity (operating areas and transfer corridors) through the cells, and is exhausted through HEPA filters. Interlocking doors are provided, where necessary, to maintain this ventilation pattern.

The laboratory section of Wing $M$ is designed for handling alpha- and beta-emitting materials, which do not normally require shielding but do require ventilation and containment to avoid inhalation or ingestion. Activity levels are generally in the microcurie to millicurie range. Standard hoods or gloveboxes are used, and radiation safety precautions are the same as those observed in other laboratory areas of Bldg. 200. All exhaust air from laboratories is passed through HEPA filters.

\subsubsection{Bldg. 212, Special Facility FDl2}

The experiment facilities in Wing D of Bldg. 212, known as Special Facility FD12, have been designed to allow a wide variety of studies on plutoniumcontaining samples; the work, however, is not limited to plutonium. Nearly all activities are carried out in sealed gloveboxes, most of which have a dry, nitrogen-gas atmosphere. Gloveboxes are gas-tight enclosures and, except for three boxes with an air atmosphere, are supplied with a slow-flowing, oncethrough inert gas atmosphere designed to minimize fire and explosion hazards. Exhaust gases are passed through double HEPA filters before release. Materials 
are introduced and removed in sealed plastic pouches or via push-through entry ports. A few gloveboxes contain air, helium, or argon gas. Some work is done on clad specimens in selected room areas that are outlined by red floor stripes. The entrances to the laboratory areas are through locked access doors; entry requires both a badge containing a special insert and knowledge of a threedigit code.

The major operations in FDl2 are:

(a) Cutting, weighing, and cleaning of bulk plutonium metal for further use.

(b) Melting and casting, which may involve pure plutonium or plutonium alloys or compounds.

(c) Reacting plutonium with appropriate gases to prepare plutonium compounds, e.g., oxide, carbide, nitride, etc.

(d) Heat treating samples to yield the desired phases.

(e) Metallographic, X-ray, and microprobe analyses to verify the product phases.

(f) Physical measurements of a wide variety. These may range from high-temperature mechanical behavior, to studies of compatibility with fuel element jackets, to low-temperature magnetic studies.

(g) Loading specimens into fuel element jackets, special capsules, capillaries, etc.

(h) Inspecting clad specimens in designated room areas.

(i) Converting wastes to chemically inert species by burning.

The plutonium research equipment is enclosed in gloveboxes with complete containment of the plutonium for normal handling operations.

Tornado protection similar to that described for the hot cell in Section 2.1.4.4 exists for the FD12 Facility.

\subsubsection{New Brunswick Laboratory}

The New Brunswick Laboratory (NBL) of DOE was relocated from New Jersey to ANL in 1977. Although NBL is directly operated by DOE, its operating policies and procedures in the areas of safety, environmental controls, and emergency planning are necessarily compatible with comparable ANL policies and procedures. The NBL Director reports to the Manager, DOE Chicago Operations office.

NBL operations are divided into four general programs: analysis; preparation and/or characterization of standards and reference materials; evaluation programs; and methods development. Chemical and instrumental analyses of nuclear materials--including but not restricted to materials containing uranium, 
thorium, boron, and plutonium, ranging from high-purity metal and oxides to low-purity scrap--are performed using specific techniques and methods previously developed that provide highly accurate and precise results. The purpose of these measurements may range from the characterization of material to be used nationally and internationally as a chemical or mass-spectrometric reference, to verification of material from a safeguards inventory by DOE or NRC (U.S. Nuclear Regulatory Commission) inspectors. Development of new methods or improvements to existing methods for the analysis of plutonium- and uranium-containing materials is carried out in parallel with the sample analysis effort.

Sample materials are received in approved shipping containers, surveyed and unpacked, and stored in an approved vault or storage room until analysis can begin. Unused sample material and other recoverable material are packaged for shipment to designated DOE recovery sites. Nonrecoverable material is packaged as required for authorized disposal.

The NBL plutonium area includes four high-level plutonium laboratories, a low-level laboratory, a cold laboratory, two plutonium mass-spectrometry laboratories, and an emission-spectroscopy laboratory.

The service floor of the building is divided into two sections. The machine shop, Iunchroom, emergency generator, and other mechanical equipment are located in the cold section. The hot section contains storage space for mechanical and contaminated equipment, the plutonium liquid waste retention tanks, and the acid fume scrubber exhaust system. The second floor of the building contains ventilation equipment. All exhaust air from plutonium laboratories is passed through HEPA filters.

Generally, in all laboratories, closed boxes are used for handling plutonium solids in any quantity, for storage of samples in process, for handling plutonium in excess of $50 \mathrm{~g}$ in solution, and for operations such as opening glass ampules, solvent extraction, and centrifugation. Open boxes are normally used for handling plutonium solutions containing up to a maximum of about $50 \mathrm{~g}$ (usually less than $5 \mathrm{~g}$ ), where no operations such as solvent extraction or fusions are involved, and for handling of milligram amounts of adherent solids, such as plutonium sulfate, when fumed in coulometry cells. The NBL uranium area includes wet chemistry laboratories on the ground and second floors, plus laboratories for mass spectrometry, optical emission and x-ray spectrography, non-destructive assay, and flammable-solvent-related operations. The service floor contains heating, ventilating, and air conditioning equipment, waste retention tanks, and nuclear material storage facilities. The third floor contains ventilating equipment and an electronics/instrumentation laboratory.

\subsubsection{Gammabeam-650 Cobalt-60 Irradiator}

The Division of Biological and Medical Research (BIM) uses several cobalt-60 sources in its experimental animal programs. The largest of these is the Gammabeam-650, located in Bldg. 202. This irradiator consists of 12 source tubes that surround the target. Each tube contains three linearly connected cobalt-60 source capsules that are driven up into the tube by air pressure. Each source capsule is barrel-shaped, with a length of $3.8 \mathrm{~cm}$ and waist diameter of $2.1 \mathrm{~cm}$. It consists of nickel-plated cobalt pellets, doubly encapsulated in welded stainless steel. Release of the air pressure causes 
the capsules to drop into the shielded storage container. At full strength; each capsule may contain as much as $1500 \mathrm{Ci}$ of cobalt-60; currently, the average source capsule contains about $300 \mathrm{Ci}$.

\subsubsection{Special Nuclear Material Vaults}

Although the Special Materials Division (SPM) operates Special Nuclear Material (SNM) storage facilities in several buildings, the major vaults are located in Bldgs. 316, 350, and 331A. The last is the main facility used for the storage of enriched uranium, whereas the second is used primarily for plutonium storage. The vault in Bldg. 316 is used for the storage of ZPR plutonium and enriched uranium fuel plates. SNM leaves the vaults only when issued to a user organization or for shipment elsewhere. When a user is finished with the material, it is returned to SPM for storage or other disposition.

The three above-mentioned storage areas consist of a total of five vaults; in addition, NBL operates similar facilities in Bldg. 350 . The plutonium vaults and the Bldg. 33lA uranium vault were analyzed to determine their capability to withstand the forces accompanying a Region-I design basis tornado (U.S. At. Energy Comm. 1974a); as a result, modifications necessary to enable the vaults to meet those severe criteria were accomplished.

Basically, the vaults are constructed of reinforced concrete. All storage areas are appropriately instrumented to detect and signal fire, smoke, criticality, and intrusion. A ventilation system maintains each vault at a negative pressure with respect to its surroundings. The exhaust air is vented through one or more HEPA filters.

Operations associated with the storage facilities are documented in a Criticality Hazards Control Statement (CHCS) for each facility. The controls embodied in the CHCS system are discussed in detail in Section 3.4.3.3.5.

\subsubsection{Water Supply System}

Water for domestic and laboratory use is pumped from four wells on the Argonne site, each approximately $90-\mathrm{m}$ deep. The source is the Niagaran dolomite formation. The water is softened using the cold lime-soda process, chlorinated, and filtered. The final $\mathrm{pH}$ is adjusted with sulfuric acid and small amounts of polyphosphate are added for stabilization. Approximate amounts of chemicals added per year for treatment are:

$\begin{array}{lr}\text { Hydrated lime } & 806,000 \mathrm{~kg} \\ \text { Aluminum sulfate } & 858,700 \mathrm{~kg} \\ \text { Soda ash } & 251,300 \mathrm{~kg} \\ \text { Sulfuric acid } & 94,200 \mathrm{~kg} \\ \text { Polyphosphate } & 2,720 \mathrm{~kg} \\ \text { Chlorine } & 1,580 \mathrm{~kg}\end{array}$

The treated water is pumped to elevated storage tanks for building distribution. Water for laboratory and fire use is taken from the main treatment plant; however, an entirely separate distribution system is used. Sludges and backwashing liquids are transferred to a 2.8 -ha settling pond with a $26.5 \mathrm{~m}^{3} / \mathrm{d}$ runoff into Sawmill Creek. Water usage averages about $3430 \mathrm{~m}^{3} / \mathrm{d}$, compared with an average DuPage County usage in 1974 of $260,000 \mathrm{~m}^{3} / \mathrm{d}$. 
Water for process cooling is withdrawn from the Chicago Sanitary and Ship Canal and pumped to a treatment facility on the south side of the site (Bldg. 583). Treatment primarily consists of suspended solid settling and chlorination. The plant capacity is about $15,000 \mathrm{~m}^{3} / \mathrm{d}$, with average annual throughput of about $700,000 \mathrm{~m}^{3}$. Sludges, mainly canal water silt, are pumped to lagoons for dewatering and drying.

\subsubsection{Waste Handing Facilities}

ANL produces waste materials of varying toxicity that ultimately require disposal in an environmentally acceptable manner. In this section, the ANL facilities and systems that are used in the storage, treatment, and disposal of such materials are discussed.

\subsection{Sanitary Waste Treatment}

Sanitary wastes are collected from. the various buildings and facilities in an ordinary sewer system with a total trunk length of about $6 \mathrm{~km}$. The sewage either flows by gravity or is pumped to the treatment facility located near the southeast perimeter of the area. Treatment occurs in six phases as follows :

(a) Continuous, automatic grinding for coarse suspended matter.

(b) Primary treatment in the clarigester to separate suspended matter by sedimentation, and treatment of the separated matter by digestion.

(c) Biological treatment by means of a trickling filter that converts nonsettleable substances into a sludge that will settle, and biochemical stabilization of some of the putrescible organic matter.

(d) Separation of the waste material rendered settleable in Step c by means of sedimentation in a final clarifier, and pumping the solid material back to the inlet of the clarigester for digestion.

(e) Intermittent removal of finely divided particles with sand filters, and stabilization by biological action of any putrescible organic matter remaining in colloidal or dissolved state. This process completes the treatment and produces a clear, clean effluent.

(f) The effluent is disinfected by chlorination as the final step in the treatment procedure. This is effected in the chlorine contact chamber and ensures destruction of any pathogenic. organisms present.

The plant consists of two identical parallel systems with design average flows of about $800 \mathrm{~m}^{3} / \mathrm{d}$ for each system. The average total flow is about $1100 \mathrm{~m}^{3} / \mathrm{d}$. The final discharge is to Sawmill Creek, about $1200 \mathrm{~m}$ south of the treatment plant and $300 \mathrm{~m}$ above the confluence of Sawmill Creek and the Des Plaines River.

The tertiary treatment system is designed to remove $96 \%$ of the BOD and $100 \%$ of settleable solids; the system quality exceeds state standards. Effluents and sludges are regularly checked for radioactivity before release. No activity above the permissible discharge limits has ever been detected in 
the effluents; however, occasionally radioactivity has been detected in the sludge. In such cases, the sludge is handled and disposed of as low-level solid radioactive waste. Normal sludges are disposed of in the sanitary landfill (see Section 2.1.4.12.4).

\subsection{Laboratory Waste Treatment}

Most of the newer ANL laboratory/office buildings are served by separate sanitary and laboratory drains. The latter are provided in laboratory areas for the purpose of handling liquid radioactive wastes, although ANL policy requires that such wastes be removed in containers. However, the likelihood that trace amounts of activity may be inadvertently disposed via a sink drain led to the provision of the laboratory waste system. The overall system for handling radioactive or suspect wastes is outlined in Figure 2.7.

Liquids from sinks or drains located in areas where radioactive materials are used are collected in building retention tanks and are released to the sewer system only after monitoring shows that the activity level is acceptable. Liquids that do not meet acceptable standards are pumped into tank trucks for delivery to the Liquid Waste Processing Facility (BIdg. 306; see Section 2.1.4.12.3). Liquids released to the laboratory sewer system flow to the laboratory waste treatment plant which is adjacent to the sanitary sewage treatment plant.

The laboratory waste treatment plant consists of holding (settling) tanks, flow meters, screening, chemical feed and control equipment, mixing tank and mixers, ion-exchange units, flow equalizing pond and recirculating pumps. The plant holds waste to permit testing, to neutralize acid or alkali waste, and to remove solids. The laboratory wastewater is collected in six concrete holding tanks with individual capacities of $261 \mathrm{~m}^{3}$. The flow equalizing pond receives overflow from holding tanks and moderates flow surges during chlorination.

When a tank is full, the inlet valve is closed, the water recirculated for adequate mixing, and a sample taken. The tank contents are held until clearance for dumping is received from the PFS-WMO Analytical Laboratory. If activity above permissible dump levels is found from the analysis, the tank is held for a decay period or for processing through the ion-exchange facility. This consists of a cation and mixed-bed ion-exchange unit, with the regeneration waste products being directed to a portable tank for transportation to Bldg. 306 for treatment and disposal. The operation of the ion-exchange units has rarely been required.

The flow from each tank is directed through connecting sewers to the sanitary sewage treatment plant chlorine contact chamber where the sanitary and laboratory waste effluents are combined. The chamber has automatic chlorination equipment, with a continuous recorder readout. The combined chlorinated laboratory-sanitary effluent is sampled by an automatic proportional sampler and samples are analyzed daily. The average flow from the plant is about $13,000 \mathrm{~m}^{3} / \mathrm{d}$, giving a combined sanitary and laboratory systems flow of about $20,000 \mathrm{~m}^{3} / \mathrm{d}$. The discharges are discussed in Section 3.1.2.2.2. 


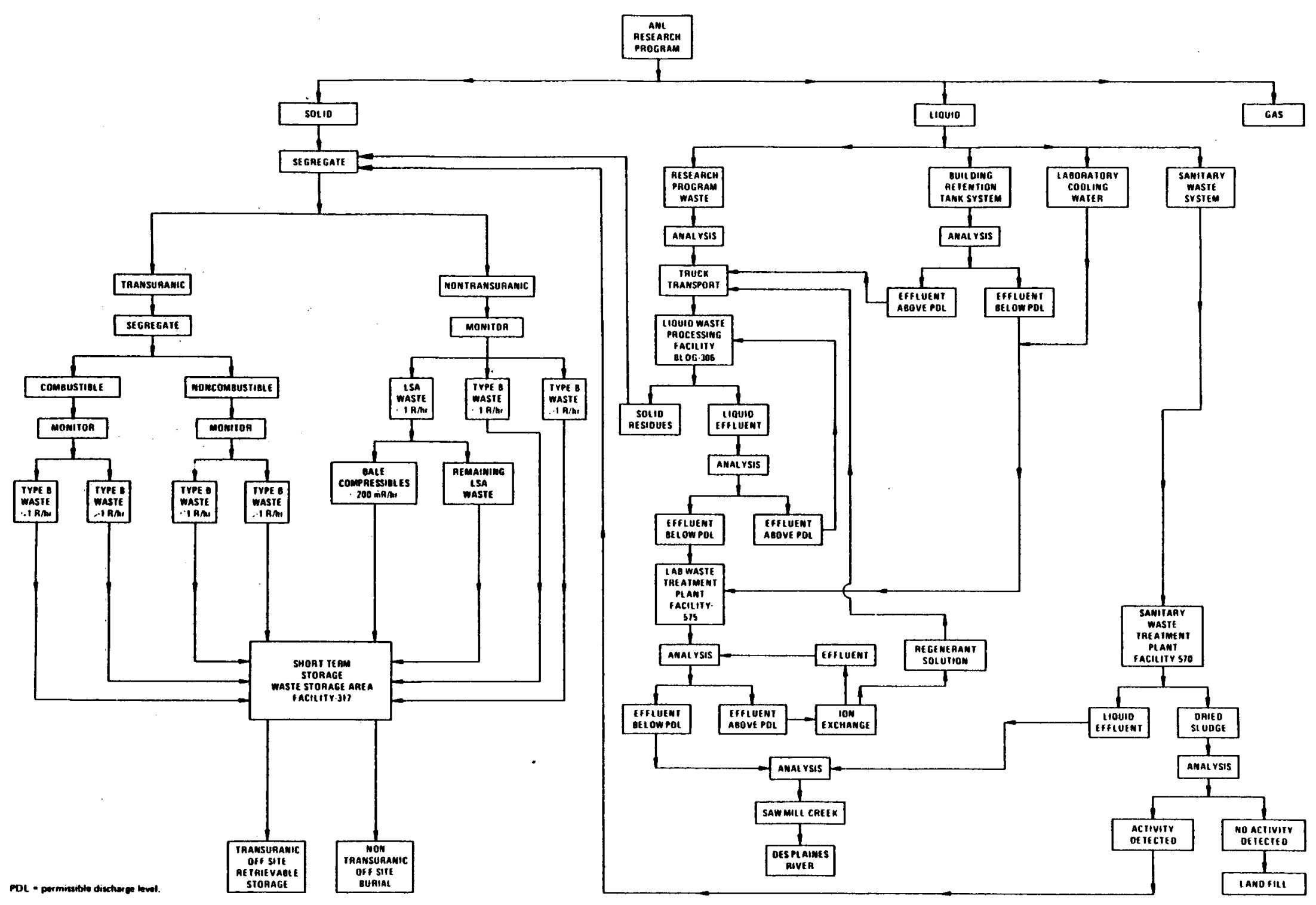

Figure 2.7. Flow Chart for ANL Radioactive Waste Handling. 


\subsection{Liquid Waste Handling}

To ensure that the radioactivity in liquids discharged into Sawmill Creek is below regulated legal levels set by EPA, criteria have been established by ANL for discharges from laboratory retention tanks and the laboratory waste system as follows:

\section{Type of Activity}

Alpha emitters

Beta emitters (other than strontium-90)

Strontium-90
Yearly Limit $(\mathrm{Ci})$

$$
0.15
$$

0.45

These allowable releases result in the following criteria for building retention tanks and the laboratory waste treatment plant:

\section{Retention Tank Discharge Criteria}

(a) If gross activity $\leqq 100 \mathrm{D} * / \mathrm{mL}$ : discharge to laboratory waste treatment system.

(b) If gross activity $\geqq 1000 \mathrm{D} / \mathrm{mL}$ : contents of the retention tanks must be pumped and transported to the waste processing facility for processing to remove radioactivity.

(c) If gross activity is between 100 and $1000 \mathrm{D} / \mathrm{mL}$ : make an analysis for alpha activity;

1. If alpha activity $\geqq 5 \mathrm{D} / \mathrm{mL}$ : contents of retention tank must be transported to the waste processing facility for treatment.

2. If alpha activity $<5 \mathrm{D} / \mathrm{mL}$ : make an analysis for strontium-90;

a. If strontium-90 $\geqq 10 \mathrm{D} / \mathrm{mL}$ : contents of retention tank must be transported to the processing plant for treatment.

b. If strontium-90<10 D/mL: discharge to laboratory waste treatment system.

Laboratory Waste Treatment Plant Discharge Criteria

(a) Gross count (alpha plus beta) $<5 \mathrm{D} / \mathrm{mL}$ and alpha count $<1 \mathrm{D} / \mathrm{mL}$ : discharge to outfall for release to Sawmill Creek.

(b) Gross count $\geqq 125 \mathrm{D} / \mathrm{mL}$ : hold and process to remove radioactivity until criteria for release to environment are met.

(c) Gross count $<125 \mathrm{D} / \mathrm{mL}$, but $\geqq 5 \mathrm{D} / \mathrm{mL}$ and/or alpha count $\geqq 1 \mathrm{D} / \mathrm{mL}$ : make further analysis;

\footnotetext{
$\bar{D}=1$ disintegration/minute
} 
1. If strontium-90 level $\geqq 2 \mathrm{D} / \mathrm{mL}$ and/or alpha level $\geqq 1 \mathrm{D} / \mathrm{mL}$ : obtain administrative ruling from ANL management (decision to process or to discharge may depend on the nuclide causing alpha contamination).

2. If strontium-90 level $<2 \mathrm{D} / \mathrm{mL}$ and alpha level $<1 \mathrm{D} / \mathrm{mL}$ : discharge to outfall for release to the environment.

Liquids that have been transferred to the Liquid Waste Processing Facility (Bldg. 306) can be treated using one or more of the following processes:

(a) Radioactive liquid waste collected in containers from retention tanks or from the ion-exchange process is treated at the processing facility with equipment for evaporation, filtration, flocculation, vermiculite absorption, and ion-exchange.

(b) Most aqueous liquid waste processed is reduced to a semisolid by evaporation. Chemically neutralized liquid waste is fed to a stainless steel, single effect, natural circulation evaporator with a capacity of about $0.6 \mathrm{~m}^{3} / \mathrm{h}$. The evaporated liquid is condensed and collected in a $15-\mathrm{m}^{3}$ holding tank for monitoring before discharge. It must meet the same requirements as building retention tanks. The bottoms, after they have reached $20 \%$ solids content, are removed from the evaporator and temporarily stored in $0.75-\mathrm{m}^{3}$ stainless steel tanks.

(c) Evaporator bottoms are further volume-reduced in a $0.38-\mathrm{m}^{3}$ batch evaporator-concentrator with a capacity of about $0.1 \mathrm{~m}^{3} / \mathrm{h}$. This waste is concentrated so that the resulting sludge will be a solid or nearly so upon cooling. While still hot, this slurry is drained from the concentrator into $0.2-\mathrm{m}^{3}$ black iron drums filled with vermiculite that absorbs any remaining liquid. Each drum is held for several days and then probed to ensure that the contents are completely solidified. Additional vermiculite is added if any free liquid is found. Concentrator-evaporated liquids are returned to the evaporator for processing as described above.

(d) Wastes suitable for treatment by flocculation are pumped to a $7.5-\mathrm{m}^{3}$ stainless steel tank. Caustic soda ( $\mathrm{NaOH})$ is added and the contents are agitated for a short period of time and then allowed to settle. Sludge from this process is further treated by evaporation. Activity removal by flocculation ranges between 50 and $90 \%$, for a decontamination factor of 2 to 10 .

(e) Absorption with vermiculite is provided for aqueous wastes and those with high solids or radioactivity content. Acid solutions are neutralized. Wastes are added to vermiculite-filled drums at a ratio of about one part liquid to two parts vermiculite, resulting in solid active waste. The solid wastes produced are discussed below.

Hazardous nonradioactive liquids--such as waste solvents, oil, polychlorinated biphenyls (PCBs), mercury, and other toxic liquid wastes--are handled in accordance with U.S. Environmental Protection Agency (EPA) regulations. Waste oil is collected and sold for reclaiming. Mercury is reprocessed for reuse. Halogenated hydrocarbon solvents are redistilled for reuse. Flammable toxic solvents are collected and stored for shipment to offsite EPA-approved disposal facilities pending acquisition of an onsite incinerator. Polychlorinated 
biphenyls are stored in a diked storage building pending EPA-approved disposal. Carcinogens and other toxic liquids are stored in the ANL Waste Treatment Facility pending shipment to EPA-approved offsite disposal facilities.

\subsection{Solid Waste Handling}

Solid wastes are classified as nonhazardous or hazardous. In the former category are scrap metal, construction debris, paper, etc. Unless this material is recyclable or otherwise salvageable, it is buried in a sanitary landfill located on the western edge of the ANL site (Figure 2.8). This is a level, fenced-off area, about 9 ha in extent. The surface and perimeter are hard impervious clay and silt clay. Test borings at the landfill site indicate the presence of a thick clay layer below the landfill. Permeability tests run on samples of this underlying clay exhibited coefficients of permeability between $8 \times 10^{-8}$ and $1 \times 10^{-8} \mathrm{~cm} / \mathrm{s}$. Clay soils with permeabilities on this order of magnitude are considered practically impervious. Horizontal permeability within the landfill is considerably greater but would still be considered low. Hydrologic analyses at the site show a perched water table at about $7.5 \mathrm{~m}$ below the landfill, with a flow pattern in a generally southern direction toward the nearby Des Plaines River.

In operation, compacted waste is dumped in 0.3 - to $0.6-\mathrm{m}$ layers, recompacted, covered with $0.15 \mathrm{~m}$ of clay, and again compacted. Less than $10 \%$ of the rain falling on the fill is expected to penetrate the clay cover, and a much smaller fraction is expected to enter the underlying ground or perched water. Surface water runs off into two systems of marshes, ditches, and natural watercourses before finally entering Sawmill Creek. Runoff water is monitored for $\mathrm{pH}$ and $\mathrm{BOD}$ at points about $240 \mathrm{~m}$ west and $450 \mathrm{~m}$ southeast of the landfill area.

Hazardous solid waste includes radioactive and nonradioactive materials. Solid radioactive wastes are not permanently stored at ANL; rather, they are appropriately packaged in accordance with DOE and DOT (U.S. Department of Transportation) criteria and shipped to a DOE-approved disposal site.

As solid radioactive waste is produced, it is placed in special containers with appropriate shielding as necessary. The containers are labeled, surveyed for activity, and picked up either when full or when indicated by external radiation readings. Transuranic waste is kept separate from nontransuranic waste and appropriately labeled. Filled waste containers are transported to the 4-ha waste holding area (Facility 317) where they are classified and prepared for shipment. Compressible material of low activity is compressed into bales for shipment.

Bins and drums that do not require shielding for offsite shipment are kept at grade level on a gravel pad. Those that do require such shielding are held in six underground shielded vaults equipped for different sizes of material and different levels of radioactivity. For offsite shipping, the waste is segregated into four classifications according to quantity, type, surface dose rate, and shielding requirements. Depending upon the classification, one of two types of shipping containers is used. The more common is a $3.4-\mathrm{m}^{3}$ reinforced steel bin which meets DOT requirements. The second type of shipping container is a $0.21-\mathrm{m}^{3}$ drum which is placed inside a $0.15-\mathrm{m}$-thick lead shipping cask. Prior to shipping, each container is sealed, numbered, weighed, labeled, 




Figure 2.8. ANL Site Plan Showing Locations of Sanitary Landfill, Boiler Plant, and Coal Storage Pile. 
and surveyed for radiation. The DOT maximum permissible radiation levels for packaged shipments are $10 \mathrm{mR} / \mathrm{h}$ at $1.8 \mathrm{~m}$ and $1.2 \mathrm{mR} / \mathrm{h}$ at $15 \mathrm{~m}$.

Hazardous nonradioactive solid wastes are treated in accordance with EPA guidelines for hazardous waste treatment or are packaged for shipment to offsite EPA-approved disposal facilities. Sodium or other alkali metals are reacted with alcohol or water to make them nonreactive. Biological wastes containing potentially pathogenic organisms are sterilized by autoclaving or disinfectants.

\subsubsection{Boiler Plant}

The boiler plant at ANL (Figure 2.8) consists of four gas/oil-fired boilers (Nos. 1-4) and one coal-fired boiler (No. 5) that provide the steam requirements of the entire Laboratory. The steam produced by the five boilers is used primarily for space heating, but also for refrigeration and for driving emergency electrical turbogenerators. The average total steam production is about $60,000 \mathrm{~kg} / \mathrm{h}$, and the maximum total is $122,000 \mathrm{~kg} / \mathrm{h}$.

Boiler No. 5 was installed in 1965. It has a rated capacity of $77,000 \mathrm{~kg} / \mathrm{h}$ at a gauge pressure of $1400 \mathrm{kPa}$, which is equivalent to about $2.24 \times 10^{11} \mathrm{~J} / \mathrm{h}$. The other four boilers were installed in $1949,1949,1953$, and 1960, and each has a rated capacity of $39,000 \mathrm{~kg} / \mathrm{h}$. The latter four boilers were originally constructed to burn coal using rotograde-spreader stokers; however, in 1973, the grates were removed and replaced by burners capable of using natural gas or No. 2 to No. 6 fuel oil. Boilers 1-4 currently use natural gas. Boiler No. 5 originally had both natural gas and spreader-stoker-fired coal capacity. The gas burners were replaced by combination gas and oil burners, as in the smaller boilers, but the coal grates were retained in usable form. The grates were bricked over for protection and all other coal-handling equipment was retained in mothballed form until 1980 at which time this boiler was converted to coal. Mechanical cyclones are in place for fly-ash removal, and a dry $\mathrm{SO}_{2}$ scrubber is being installed on Boiler No. 5 so that high-sulfur coal can be burned. The scrubber will be operational in late 1981. Low-sulfur coal was used prior to installation of the scrubber.

The boilers are housed in a brick building ( $B 1$ dg. 108), having dimensions of $50.9 \mathrm{~m} \times 23 \mathrm{~m} \times 27 \mathrm{~m}$ high. The three stacks are each $45 \mathrm{~m}$ high and $2 \mathrm{~m}$ in diameter. The tops of the stacks are $24 \mathrm{~m}$ above the roofline of the boiler building.

Associated facilities outside Bldg. 108 are the coal-storage and -handling equipment and the oil-storage tanks. The coal-handling facilities include railroad tracks, a railcar-unloading structure, coal hoppers and storage areas, a coal crusher, and conveyors to transport the coal between the various areas and the storage bunkers in Bldg. 108.

\subsubsection{Particle Accelerators}

A particle accelerator can be classified according to the energy it produces, the particles (beam) it accelerates, and the principle by which it operates. The radiation levels during operation and during accelerator shutdowns vary with the energy and type of particle accelerated. Also, the radiation levels, both during operation and after shutdown, depend upon the principle of operation employed. 
The principles by which an accelerator works generally can be classified as magnetic confinement plus electric field (e.g., cyclotron), electrostatic generation (Van de Graaff, and the X-ray machine), linear acceleration by resonance (time-varying electric field) cavities, and secondary beam generation by bombarding a primary target. Argonne National Laboratory has accelerators based upon each of these four principles.

The Intense Pulsed Neutron Source (IPNS) is housed in several buildings and began operating in 1981. The pre-injector, linac, and accelerator control room are in Bldg. 360; the rapid-cycling synchrotron is in Bldg. 39l; and the neutron generating targets are in Bldg. 375. Numerous auxiliary buildings are also associated with the system. Protons are accelerated by a $50-\mathrm{MeV}$ linear accelerator, injected into the $500 \mathrm{MeV}$ synchroton, and bombarded into targets to produce neutrons in the energy range of about $1 \mathrm{MeV}$. The IPNS is designed to operate at currents up to $22 \mu$ Amps $(\mu A)$ of neutrons, but the staff expects the neutron beam will seldom exceed $10 \mu \mathrm{A}$. The IPNS is a scaled-up version of the ZING $\mathrm{P}^{\prime}$, which was a prototype of IPNS. Because of the intense neutron fields, the area surrounding the neutron source and experimental areas is secured with interlocks to prevent access during operation.

Two Febetrons are housed in Bldg. 200. These are essentially $\mathrm{X}$-ray tubes used to produce a $2-\mathrm{MeV}$ and $600-\mathrm{KeV}$ beam of $\mathrm{X}$-rays. An 8-MV tanden Van de Graff, housed in Bldg. 314 , is used to accelerate a $4-\mu \mathrm{A}$ beam of protons onto a target to obtain 4-MeV neutrons for applied physics research. This accelerator is known as the "fast neutron generator."

There are several accelerators in Bldg. 211: a cyclotron, an electron linac, a small Van de Graaff, and a low-energy Cockroft Walton. The cyclotron accelerates particles up to energies and currents as follows:

\begin{tabular}{|c|c|c|}
\hline Particle & $\begin{array}{l}\text { Energy } \\
(\mathrm{MeV})\end{array}$ & $\begin{array}{c}\text { Current } \\
(\mu \mathrm{A})\end{array}$ \\
\hline Proton & 10.7 & 100 \\
\hline Deuteron & 21.5 & 100 \\
\hline Triton & 33 & 90 \\
\hline Alpha & 43 & 65 \\
\hline
\end{tabular}

Among other uses, the cyclotron is used for irradiation of targets for medical research. The cyclotron is in an interlocked area during operation. The main exposures occur during the frequent handling of the targets. The 22-MeV electron linac can produce beams of energy from the $\mathrm{mA}$ to the KA range. In addition to the radiation produced along the linac beam line and target area, the Klystrons which power the linac emit high-level $\mathrm{X}$-ray radiation. The 3-MeV Van de Graaff normally produces electron beams of 3 to $10 \mu \mathrm{A}$. The $150-\mathrm{keV}$ Cockroft Walton is used as a positive ion accelerator.

The largest number of accelerators are housed in Building 203. These include the 9-MV tanden Van de Graaff, the superconducting linac, two 2-MV Van de Graaffs, and the dynamitron. The largest accelerator in Bldg. 203 is the 9-MV tandem Van de Graaff, whose beam is input into the superconducting linac. The tandem/linac system is capable of accelerating particles to $36 \mathrm{MeV}$ per charge. This system is used exclusively to accelerate heavy ions. The heavy ions usually generate minimal neutrons and work can proceed in the vicinity of the beam and target chamber. 
The dynamitron accelerates light nuclei up to energy levels of $5 \mathrm{MeV}$, with ion currents normally in the 10-100 $\mathrm{AA}$ range. One of the two 2-MV Van de Graaffs is used to accelerate helium currents of 10-100 $\mathrm{AA}$. The other is used to produce $100-\mathrm{keV}$ and $20-\mathrm{keV}$ beams at currents up to $400 \mu \mathrm{A}$.

The accelerators described in this section do not constitute an exhaustive list of accelerators at the ANL-East site, but include those that produce essentially all of the radiation dose to workers and offsite releases described elsewhere in this EA.

\subsection{CHARACTERIZATION OF THE EXISTING ENVIRONMENT}

The environmental features of the ANL site and the surrounding area are described in this section. Included are discussions of the physical, socioeconomic, and ecological environments that relate directly to current operations at ANL.

\subsubsection{General Description of the ANL Site}

ANL occupies a 688-hectare (ha) tract in DuPage County, Illinois, about $35 \mathrm{~km}$ southwest of downtown Chicago, and $40 \mathrm{~km}$ due west of Lake Michigan. It lies in the Des Plaines River Valley, south of Interstate Highway 55 and west of Illinois Highway 83. The relation of the Laboratory to the Chicago metropolitan area is shown in Figures 2.9 and 2.10. The laboratory and support facilities occupy about 81 ha, with the remaining 607 ha devoted to forest and landscaped areas within the site perimeter. The DuPage County Forest Preserve District operates an 826-ha green belt forest preserve, known as the Waterfall Glen Forest Preserve, which surrounds the site. Much of this forest preserve was formerly ANL property, but was deeded to the Forest Preserve District in 1973 for their use as a public recreation area, nature preserve, and demonstration forest. In the past few years, a number of industrial parks have been constructed to the north and northwest of the Laboratory. Also, many commercial establishments and a large number of dwelling units have been constructed within a few kilometers of ANL.

The site is usually denoted ANL-East, but earlier literature refers to the same site as ANL-Illinois, ANL-DuPage, or Site D. Operations and facilities at Argonne-West in Idaho are not covered in this statement. Hereafter, ANL will refer only to the Illinois site, unless otherwise noted.

The terrain is gently rolling, partially wooded, former prairie and farmland. The grounds contain a number of ponds and small streams, the principal stream being Sawmill Creek, which runs through the site in a southerly direction and enters the Des Plaines River about $2.1 \mathrm{~km}$ southeast of the center of the site (Figure 2.11). The extreme southern portion of the site drains directly toward the Des Plaines River, which flows along the southern boundary of the forest preserve. The Des Plaines River eventually joins the Kankakee River about $48 \mathrm{~km}$ southwest of ANL to form the IIlinois River, which flows into the Mississippi River near Alton, Illinois.

The largest topographical feature in the site vicinity is the Des Plaines River channel, about $1.6-\mathrm{km}$ wide. This channel contains both the river and the Chicago Sanitary and Ship Canal. Their presence extends the uninhabited 


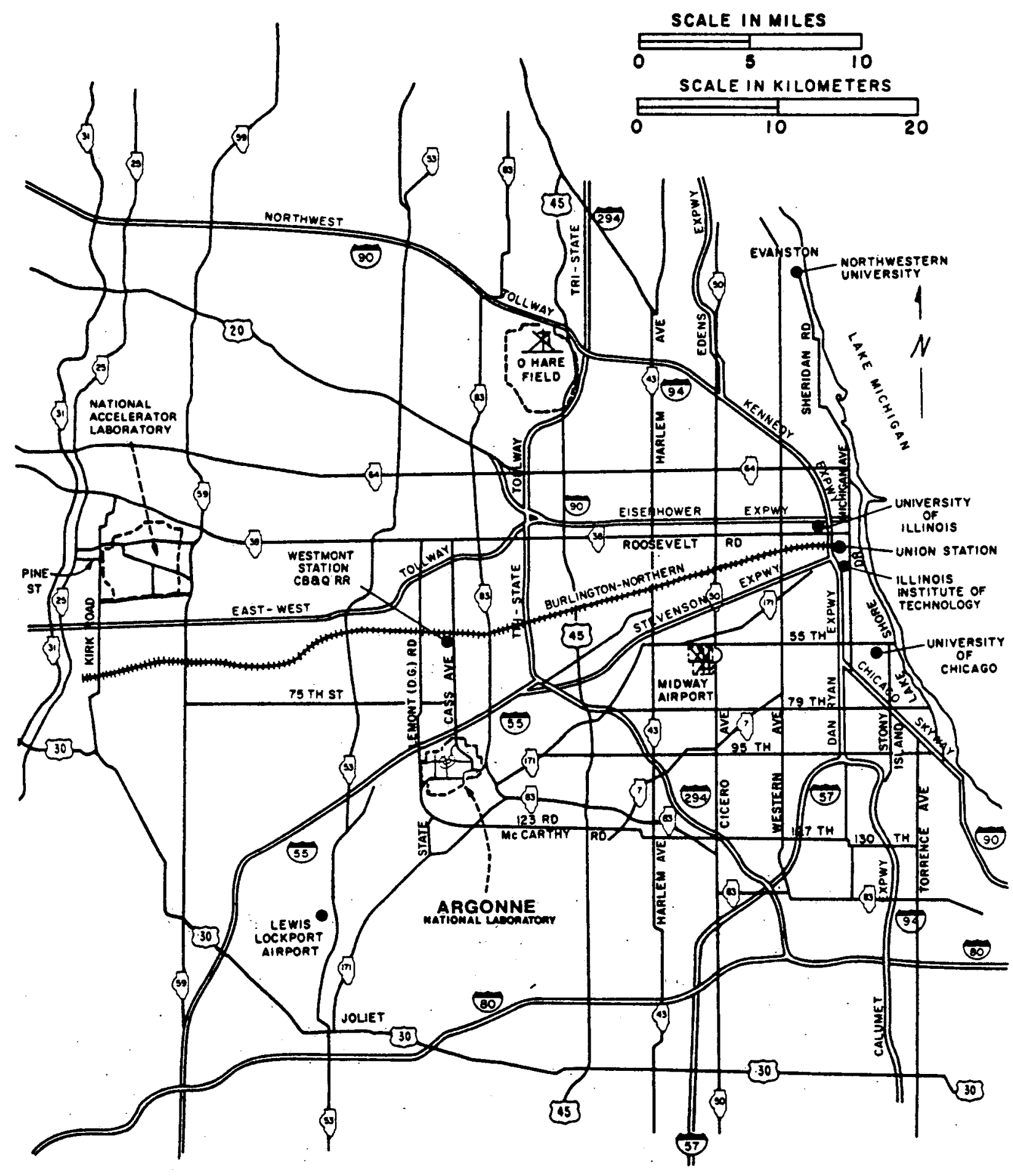

Figure 2.9. Map of Regional Area. 


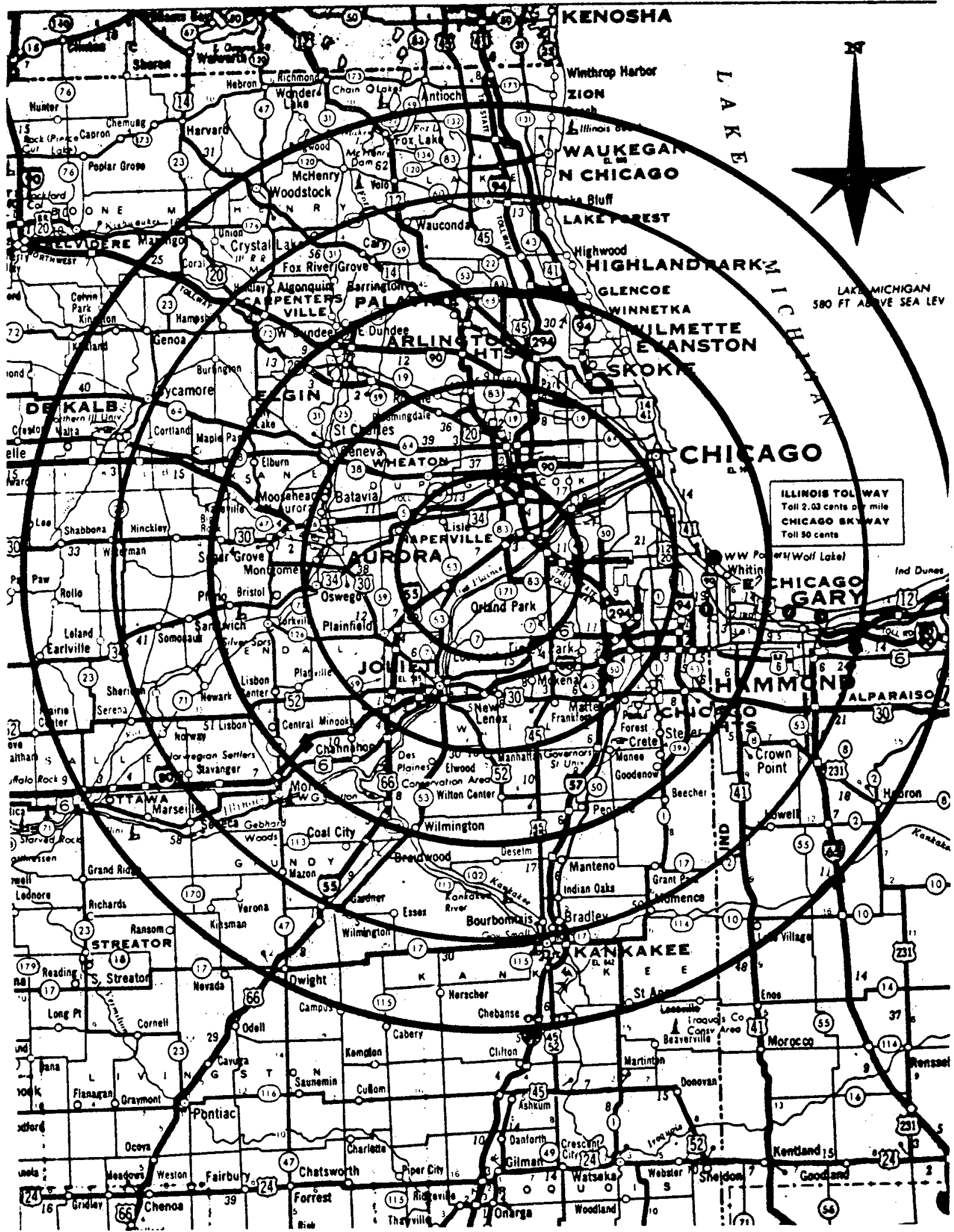

Figure 2.10. Area Around ANL Site Showing Radii of 16, 32, 48, 64 , and 80 Kilometers. 


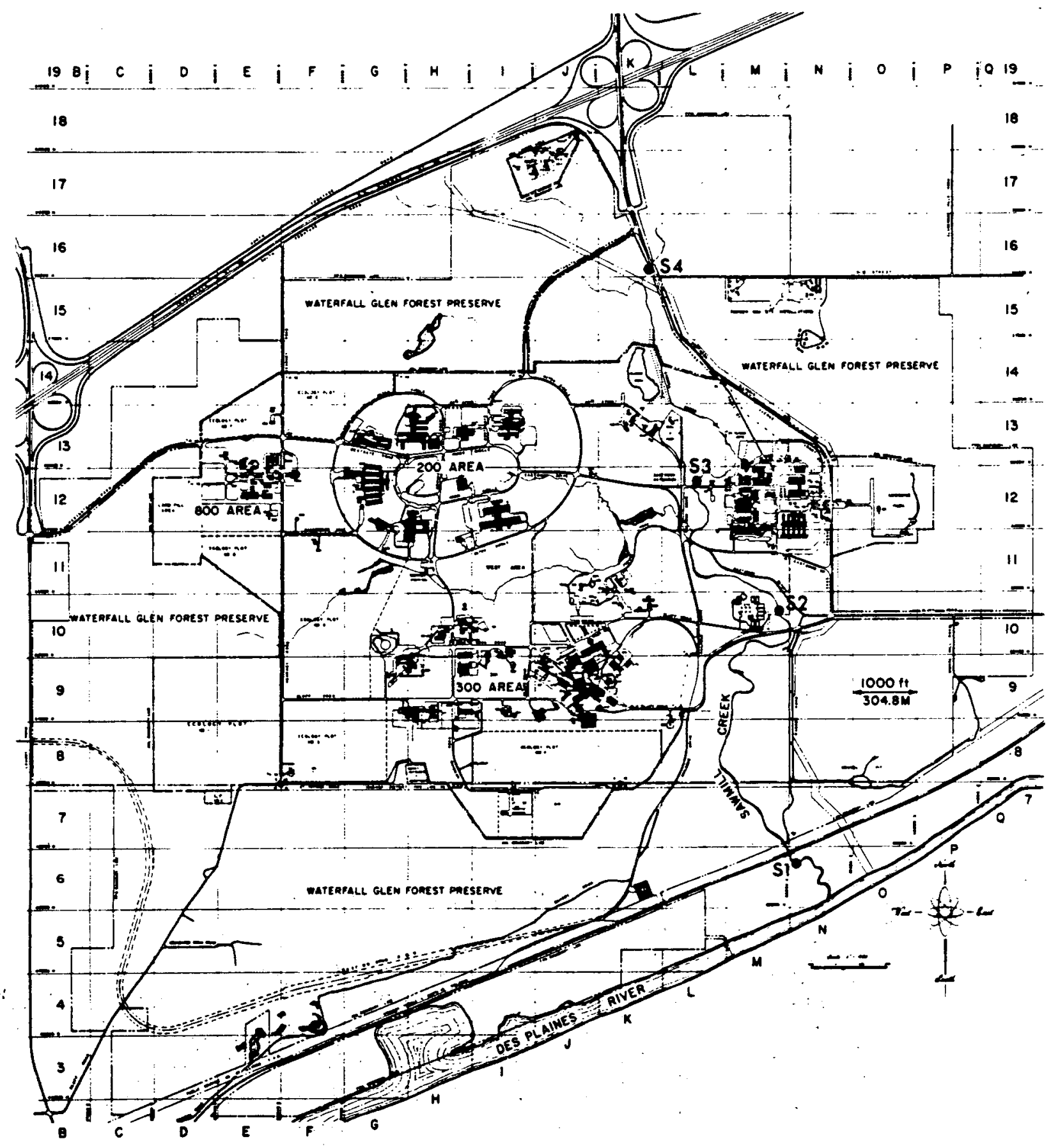

Figure 2.11. ANL Site Plan Showing Location of Sampling Stations. 
area to about $1.6 \mathrm{~km}$ south of the site. The elevation of the channel surface is $180 \mathrm{~m}$ above sea level. Bluffs, which comprise the southern border of the - site, rise from the channel at varying slope angles of 15 to 60 , reaching an average elevation of $200 \mathrm{~m}$ above sea level at the top. The land then slopes gradually upward, reaching the average site elevation of $220 \mathrm{~m}$ above sea level at $940 \mathrm{~m}$ from the bluffs. Several large ravines oriented in a north-south direction are located in the southern portion of the site. The bluffs and ravines generally are forested with deciduous trees of an average height of 15-18 m. The remaining portion of the site changes in elevation by no more than $7.6 \mathrm{~m}$ in a horizontal distance of $150 \mathrm{~m}$. In the southern portion of the forest preserve, the Chicago District Pipe Line Co. and the Atchison, Topeka, and Santa Fe Railroad have rights-of-way.

The primary resource of the ANL site is the land--which is currently devoted to woods, meadow areas, and areas devoted to research and support buildings. Before being occupied by ANL, most of the site was wooded and the remaining land was used for farming. The wooded land and surface water of ANL and the surrounding forest preserve provide habitat for deer, fox, game birds, small animals, and a herd of European fallow deer.

\subsubsection{Geology, Soils, and Seismology}

\subsubsection{Geology}

The geology of the ANL area consists of about a 30-m-thick deposit of glacial till on top of dolomite bedrock. The bedrock at ANL is the Niagaran and Alexandrian dolomite of Silurian age (about 400 million years old). These formations are underlain by Maquoketa shale of Ordovician age, and older dolomites and sandstones of Ordovician and Cambrian age. The beds are nearly horizontal.

The Niagaran and Alexandrian dolomite are about $60-\mathrm{m}$ thick in the ANL area, and are widely used in DuPage County as a source of groundwater. The Maquoketa shale separates the upper dolomite aquifer from the underlying sandstone and dolomite aquifers. This shale retards hydraulic connection between the upper and lower aquifers; the lower aquifer has a much lower piezometric level and does not appear to be affected by pumpage from the overlying Silurian bedrock (Sasman et al. 1967).

During the Pleistocene epoch, glaciers deposited drift over most of Illinois. Arcuate-shaped moraines, roughly parallel to the shoreline of Lake Michigan, were formed in the Chicago area during the last glacial stage (the "Wisconsinan" stage). The younger moraines are generally closer to Lake Michigan. ANL is on the "Keeneyville Moraine," which is part of the Valparaiso morainic system.

The southern boundary of ANL follows the escarpment of a broad valley, now occupied by the Des Plaines River and the Chicago Sanitary and Ship Canal. This valley was carved by waters flowing out of the Pleistocene-Holocene Lake Michigan (called "Lake Chicago"). The valley was eroded across the moraines, and was cut down about $30 \mathrm{~m}$ to bedrock. The valley (the "Chicago Outlet") was carved during the period of about 14,000 to 11,000 years ago, and probably had some outflow again from about 4,000 to 2,000 years ago (Willman 1971). 


\subsubsection{Soils}

The soils on the site have derived from glacial till over the past 12,000 years. Most of the soils are of the Morley series, which are moderately well-drained upland soils with $2-30 \%$ slopes. The surface layer is a dark grayish-brown silt loam, the subsoil is a brown silty clay, and the underlying material is a silty clay loam glacial till. Morley soils have a relatively low organic content in the surface layer, moderately slow subsoil permeability, and a large water capacity. These soils are well-suited to growing crops, provided there are good erosion control practices. It is difficult to establish and maintain lawns on these soils. Exposed subsoil is clayey and difficult to revegetate since it dries out and cracks and is subject to erosion.

The remaining soils along creeks, intermittent streams, bottomlands, and a few small upland areas are of the Sawmill, Ashkum, Peotone, and Beecher series. These soils are generally poorly drained and have a black to dark gray or brown silty clay loam surface layer, high content of organic matter, and large capacity for water.

\subsubsection{Seismology}

There are only four faulted areas in Illinois that are relevant to any discussion of earthquake-induced motion at the ANL site: the Sandwich Fault zone; the Des Plaines disturbance; minor tunnel faults in Chicago; and an ancient fault of apparently pre-Eau Claire age. These are all located within about $75 \mathrm{~km}$ of ANL.

In addition to the four local faulted areas, there are several areas of considerable seismic activity at moderate distances from ANL, e.g., near the southern tip of Illinois (New Madrid, Missouri) and near the mouth of the St. Lawrence River. In fact, a review of a map of the seismic history of the United States (Natl. Oceanic Atmos. Admin. 1973) shows that a number of seismic regions are located on a practically straight line extending the length of the St. Lawrence Valley and ending near New Madrid, Missouri. However, since the ground acceleration varies essentially inversely as the square of the distance from the epicenter (M.P. White Assoc. 1968), any resulting ground acceleration at ANL would be minor compared, with that arising from more nearby fault zones.

Based on an evaluation of both local and more distant fault areas, it was concluded that the maximum ground acceleration predicted for the ANL site would occur as a result of activity of the Sandwich Fault. The Sandwich Fault is the only significant fault known to exist in the ANL vicinity. It is about $120 \mathrm{~km}$ long and extends $\mathrm{N} 60^{\circ} \mathrm{W}-\mathrm{S} 60^{\circ} \mathrm{E}$. ANL lies about $31 \mathrm{~km}$ distant (N30 $\left.{ }^{\circ} \mathrm{E}\right)$ from it, near its southeastern end. This fault is believed to be post-Silurian and to have experienced only minor activity since that time. Most of its later movement was associated with glacial loading and melting.

\subsubsection{Demography and Social Profile}

\subsubsection{Demography of the Area and Vicinity}

ANL is located within the Chicago Standard Metropolitan Statistical Area (SMSA), which comprises six Illinois and two Indiana counties around the southwest corner of Lake Michigan. Its 1970 population was about 7.6 million 
(Argonne Natl. Lab. 1979a). Cook County, which includes the City of Chicago, experienced an overall population decrease of $2.3 \%$ from 1970 to 1975 when it held an estimated $5,369,328$ persons. Chicago itself declined by $8 \%$ during that time, while the rest of the county grew by $7.9 \%$ (Argonne Natl. Lab. $1979 b)$.

The nearby areas of Will and Cook Counties have generally developed at a considerably lower rate than has the DuPage County area, except along the Illinois Waterway where industrial development has taken place. The estimated 1978 population by annular sector and radius within $80 \mathrm{~km}$ of a point in the east area of the site is shown in Table 2.3. Included within the $80-\mathrm{km}$ radius are portions of Lake and Porter Counties, Indiana; portions of Kankakee, Grundy, La Salle, De Kalb, McHenry, and Lake Counties in Illinois; and all of DuPage, Will, Cook, Kendall, and Kane Counties in Illinois (Argonne Natl. Lab. 1979a).

Beyond the forest preserve at ANL's perimeter, the population density is low, except for a high-density residential area (with over 37 units per hectare and about 4500 residents) beginning $600 \mathrm{~m}$ east of the perimeter (Argonne Natl. Lab. 1979a).

DuPage County's growth rate has been the highest of any metropolitan Illinois county, increasing from 155,000 to 596,000 between 1950 and 1976 .

\subsubsection{Socioeconomic Profile}

ANL is a multiprogram laboratory with research, development, and demonstration in five major scientific and technical areas: physical science, highenergy physics, biomedical and environmental sciences, energy and environment, and engineering science. These programs require many service and support personnel.

With its work force of about 4600 persons, ANL is one of the three largest employers in DuPage County. In 1975, only 16 organizations in the county had 1000 or more employees (U.S. Bur. Census 1977). Employees commute to ANL from distances as far as $50 \mathrm{~km}$; thus the payroll is spread widely. However, nearby villages do house high numbers of ANL employees, notably Lemont (in 1977, 211 of a 5200 population) and Downers Grove (482 of a 43,800 population). About $50 \%$ of ANL employees reside within $16 \mathrm{~km}$ of the site. The Laboratory also purchases much of its utilities, outside services, equipment, and supplies locally (Argonne Natl. Lab. 1979a).

In the past several years, industrial parks have been constructed to the north and northwest of the laboratory. In addition to the large number of residences in the area, many commercial enterprises have been established (Argonne Natl. Lab. 1979a).

The Chicago metropolitan area as a whole is well traversed by major transportation corridors. ANL is located in an area served by Interstate 55 and State Highways 83 and 171 . It is also proximate to rail lines and waterways including the Des Plaines River and the Chicago Sanitary and Ship Canal. 
Table 2.3. 1978 Estimated Population Distribution

\begin{tabular}{|c|c|c|c|c|c|c|c|c|c|c|}
\hline \multirow{3}{*}{$\begin{array}{l}\text { Direction } \\
\text { from Site }\end{array}$} & \multicolumn{5}{|c|}{ Population per Distance ( $\mathrm{km})$} & \multirow{2}{*}{\multicolumn{5}{|c|}{$\begin{array}{r}\text { from Site East Area } \\
\text { In Thousands }\end{array}$}} \\
\hline & \multirow[b]{2}{*}{$0-1.6$} & \multirow[b]{2}{*}{$1.6-3.2$} & \multirow[b]{2}{*}{$3.2-4.8$} & \multirow[b]{2}{*}{$4.8-6.4$} & \multirow[b]{2}{*}{$6.4-8$} & & & & & \\
\hline & & & & & & $8-16$ & $16-32$ & $32-48$ & $48-64$ & $64-80$ \\
\hline $\mathbf{N}$ & 0 & 226 & 2,171 & 3,516 & 4,859 & 44.0 & 163 & 309 & 168 & 193 \\
\hline NNE & 0 & 124 & 1,932 & 4,314 & 2,837 & 77.5 & 420 & 449 & 99 & 0 \\
\hline NE & 0 & 347 & 1,445 & 1,233 & 1,422 & 45.7 & 505 & 626 & 0 & 0 \\
\hline ENE & 0 & 1,729 & 3,069 & 470 & 1,617 & 45.0 & 684 & 289 & 0 & 0 \\
\hline $\mathbf{E}$ & 0 & 9 & 212 & 0 & 12 & 19.2 & 653 & 508 & 13 & 26 \\
\hline ESE & 0 & 0 & 88 & 275 & 118 & 18.6 & 213 & 320 & 308 & 46 \\
\hline SE & 0 & 3 & 132 & 174 & 62 & 13.0 & 82 & 96 & 23 & 9 \\
\hline SSE & 0 & 29 & 452 & 434 & 115 & 6.1 & 23 & 11 & 14 & 19 \\
\hline $\mathbf{S}$ & 0 & 65 & 1,305 & 688 & 772 & 3.9 & 31 & 4 & 27 & 40 \\
\hline SSW & 0 & 39 & 3,741 & 4,557 & 665 & 11.8 & 97 & 8 & 18 & 7 \\
\hline SW & 0 & 408 & 157 & 88 & 84 & 15.5 & 32 & 8 & 16 & 8 \\
\hline WSW & 0 & 323 & 46 & 1,199 & 2,193 & 17.8 & 14 & 10 & 6 & 10 \\
\hline $\mathbf{W}$ & 0 & 1,242 & 740 & 7,910 & 8,852 & 13.4 & 42 & 18 & 15 & 8 \\
\hline WNW & 0 & 662 & 136 & 2,556 & 3,960 & 24.5 & 73 & 46 & 6 & 52 \\
\hline NW & 0 & 141 & 674 & 2,267 & 6,090 & 28.5 & 68 & 78 & 13 & 13 \\
\hline NNW & 0 & 212 & 1,390 & 1,470 & 3,414 & 37.0 & 101 & 135 & 91 & 66 \\
\hline Total & & 5,559 & 17,692 & 31,151 & 37,077 & 421.0 & 3,202 & 2,915 & 815 & 497 \\
\hline Cumulative & & & 23,251 & 54,402 & 91,479 & 512.0 & 3,714 & 6,629 & 7,444 & 7,941 \\
\hline
\end{tabular}

Source: Argonne National Laboratory (1980a). 


\subsubsection{Land Resources}

ANL occupies 688 ha in the Des Plaines River Valley, south of Interstate 55 and west of Illinois Highway 83. On the perimeter of the site is the 826-ha Waterfall Glen Nature Preserve. The area outside the nature preserve is mostly low-density residential suburbs, except for one high-density area $600 \mathrm{~m}$ east of the perimeter (Argonne Natl. Lab. 1979a).

DuPage County's developed land area increased between 1950 and 1976 from 30,400 to $51,400 \mathrm{ha}$. In 1976, the land-use categories occupied the following percentages of land (Argonne Natl. Lab. 1979a):

$\begin{array}{lc}\text { Residential } & 40 \% \\ \text { Commercial } & 3.8 \\ \text { Office, R\&D } & 6.3 \text { (ANL category) } \\ \text { Manufacturing } & 3.1 \\ \text { Transportation } & 23 \\ \text { Open space } & 19\end{array}$

ANL's laboratory and support facilities occupy about 81 ha, with the remaining 607 ha devoted to forest and other open areas within the site perimeter.

Large oil refineries are located about 8 and $11 \mathrm{~km}$ southwest of ANL along the Illinois Waterway, and a large coal-burning electrical generating station is also about $11 \mathrm{~km}$ to the southwest. In addition, several large pipeline terminals have been built for bulk storage of petroleum products and other chemicals.

ANL is located on federally owned land and is subject to federal and state rules governing water and air quality and to federal and state environmental-protection laws. The Laboratory was established in DuPage County before any comprehensive land-use plans were available. Nevertheless, the continued operation of ANL is consistent with the current land-use plans of DuPage and neighboring Cook and Will counties. The purposes of the landuse plans of the six northeastern Illinois counties are to provide a balance of land uses and to provide a maximum of economic, recreational, and esthetic benefits from the use of the land (Argonne Natl. Lab. 1979a).

The land-use plans for DuPage County largely correspond to current uses, i.e. mostly low-density residential with smaller fractions of other uses. About $80 \%$ of the county land is expected to be developed by the year 2000 . The largest relative increase is in the moderate-density residential category, projected to go from $1.4 \%$ to $3.3 \%$ of the developed area. DuPage County is considered to be a highly desirable area for the "office, research and development" category, which includes ANL, and the plan calls for a doubling of this area. An important concern of the plan is the establishment of open spaces for recreation as well as for buffers and green space to serve as linkages between urbanized communities. Sensitive natural-resource areas such as floodplains and water-recharge areas, which in part constitute the ANLWaterfall Glen area, are protected by the open-space limitations (Argonne Nat1. Lab. 1979a). 


\subsubsection{Climate and Meteorology}

\subsubsection{General}

The regional climate around ANL is characterized as being continental, with relatively cold winters and hot summers (Denmark 1974). The area is subject to frequently changing weather as storm systems move from the Great Plains toward the east. The weather is slightly modified by Lake Michigan, which is about $35 \mathrm{~km}$ east-northeast of the Laboratory (Denmark 1974).

Weather data for 1950-1964 are available from the ANL meteorological tower (Moses and Bogner 1967) and for 1941-1970 from Chicago's Midway Airport (Natl. Oceanic Atmos. Admin. 1980), which is $20 \mathrm{~km}$ east-northeast of the laboratory. Long-term historical data are frequently used to describe the climate and meteorology of an area. The average daily air temperature at Argonne is $8.9^{\circ} \mathrm{C}$; the value at Midway is $10.3^{\circ} \mathrm{C}$. Average diurnal variations of temperature range from $7.6^{\circ} \mathrm{C}$ in December to $11.4^{\circ} \mathrm{C}$ in May. Monthly mean and extreme temperatures as recorded at Midway Airport-Chicago are shown in Table 2.4. These values are long-term averages and do not change appreciably in only a few years.

Table 2.4. Monthly Mean and Extreme Temperatures at Midway Airport $\left({ }^{\circ} \mathrm{C}\right)^{\text {a }}$

\begin{tabular}{|c|c|c|c|c|c|}
\hline \multirow[b]{2}{*}{ Month } & \multicolumn{3}{|c|}{ Normal $(1941-1970)$} & \multicolumn{2}{|c|}{ Extreme (Year) } \\
\hline & $\operatorname{Max}$ & Min & Mean & $\operatorname{Max}$ & Min \\
\hline Jan & -0.3 & -8.3 & -4.3 & $19.4(1950)$ & $-28.3(1977)$ \\
\hline $\mathrm{Feb}$ & 1.4 & -6.6 & -2.6 & $23.9(1976)$ & $-26.1(1951)$ \\
\hline Mar & 7.0 & -1.7 & 2.7 & $27.8(1945)$ & $-21.7(1943)$ \\
\hline Apr & 15.2 & 4.7 & 9.9 & $31.1(1977)$ & $-8.9(1975)$ \\
\hline May & 21.3 & 9.8 & 15.6 & $35.0(1977)$ & $-1.7(1966)$ \\
\hline Jun & 27.0 & 15.7 & 21.4 & $40.0(1953)$ & $1.7(1945)$ \\
\hline Jul & 29.1 & 18.3 & 23.7 & $39.4(1956)$ & $7.8(1972)$ \\
\hline Aug & 28.5 & 17.8 & 23.2 & $38.3(1947)$ & $6.1(1965)$ \\
\hline Sep & 24.3 & 13.3 & 18.8 & $38.3(1947)$ & $1.1(1974)$ \\
\hline Oct & 18.4 & 7.6 & 13.0 & $34.4(1963)$ & $-6.7(1948)$ \\
\hline Nov & 8.9 & 0.3 & 4.7 & $27.2(1950)$ & $-18.9(1950)$ \\
\hline Dec & 1.8 & -5.8 & -1.9 & $21.7(1970)$ & $-25.6(1960)$ \\
\hline
\end{tabular}

ata from National Oceanic and Atmospheric Administration (1980).

Source: Argonne National Laboratory (1980a). 


\subsubsection{Winds}

The average wind speed at Argonne at a height of $45 \mathrm{~m}$ is $5.5 \mathrm{~m} / \mathrm{s}$; calm periods account for $2.0 \%$ of the time. At $5.8 \mathrm{~m}$, the average wind speed is $3.4 \mathrm{~m} / \mathrm{s}$, with calm periods occurring $3.1 \%$ of the time. Wind-direction data from Midway Airport indicate that the predominant wind direction is south, accounting for $17 \%$ of the observations. Wind directions from the south through west sectors occur nearly $50 \%$ of the time.

\subsubsection{Precipitation}

Mean and extreme precipitation values at Midway Airport are shown in Table 2.5. The average annual precipitation at Midway Airport is $874 \mathrm{~mm}$; the average at ANL is $800 \mathrm{~mm}$. Most of the precipitation falls in spring and summer and is associated with thunderstorm activity. Annual average accumulation of snow and sleet is $818 \mathrm{~mm}$.

Table 2.5. Mean and Extreme Precipitation at Midway Airport, 1941-1970

\begin{tabular}{lcccc}
\hline & \multicolumn{2}{c}{ Precipitation $(\mathrm{mm})$} & & Snow $(\mathrm{mm})$ \\
\cline { 2 - 4 } Month & Mean & Max & Min & Mean \\
\hline Jan & 47 & 103 & 7 & 251 \\
Feb & 40 & 85 & 6 & 211 \\
Mar & 69 & 136 & 8 & 191 \\
Apr & 95 & 212 & 11 & 35 \\
May & 87 & 193 & 20 & Trace \\
Jun & 100 & 225 & 20 & 0 \\
Jul & 103 & 228 & 34 & 0 \\
Aug & 80 & 246 & 20 & 0 \\
Sep & 76 & 359 & 12 & 0 \\
Oct & 67 & 306 & 5 & 7 \\
Nov & 56 & 128 & 14 & 74 \\
Dec & 53 & 169 & 8 & 274 \\
Annual & 874 & & & 1043 \\
\hline
\end{tabular}

a Data from National Oceanic and Atmospheric Administration (1980).

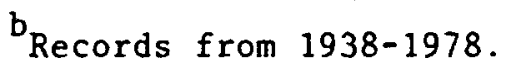

Source: Argonne National Laboratory (1980a). 


\subsubsection{Storms}

Snowstorms resulting in accumulations greater than $150 \mathrm{~mm}$ occur only once or twice each year on the average (Denmark 1974). The greatest monthly snowfall was $1000 \mathrm{~mm}$ in January 1979. The greatest 24-hour snowfall was $503 \mathrm{~mm}$ in January 1967 (Natl. Oceanic Atmos. Admin. 1980). Severe ice storms occur only once every four or five years (Denmark 1974).

The area experiences about 40 thunderstorms annually (Natl. Oceanic Atmos. Admin. 1980). Occasionally, these storms are accompanied by hail, damaging winds, or tornadoes. From 1957-1969 there were 371 tornadoes in the state, with more than $65 \%$ occurring in the spring months (Natl. Oceanic Atmos. Admin. 1970). The theoretical probability of a tornado strike at Argonne is $8.54 \times 10^{-4}$ each year, or a recurrence interval of one tornado every 1200 years (U.S. At. Energy Comm. 1974b). The ANL site was struck by tornados in 1976 and 1978, with minor damage to power lines, roofs, and trees.

\subsubsection{Air Quality}

National and state ambient air-quality standards are listed in Table 2.6. Ambient air quality in the general vicinity of ANL is monitored at several sites. The Occupational Health and Safety Division (OHS) of ANL monitors pollutants at five locations on the Laboratory property; the Illinois Environmental Protection Agency and Commonwealth Edison Company collect data from a number of sites around the Laboratory. Ambient air-quality monitoring-station locations are shown in Figure 2.12.

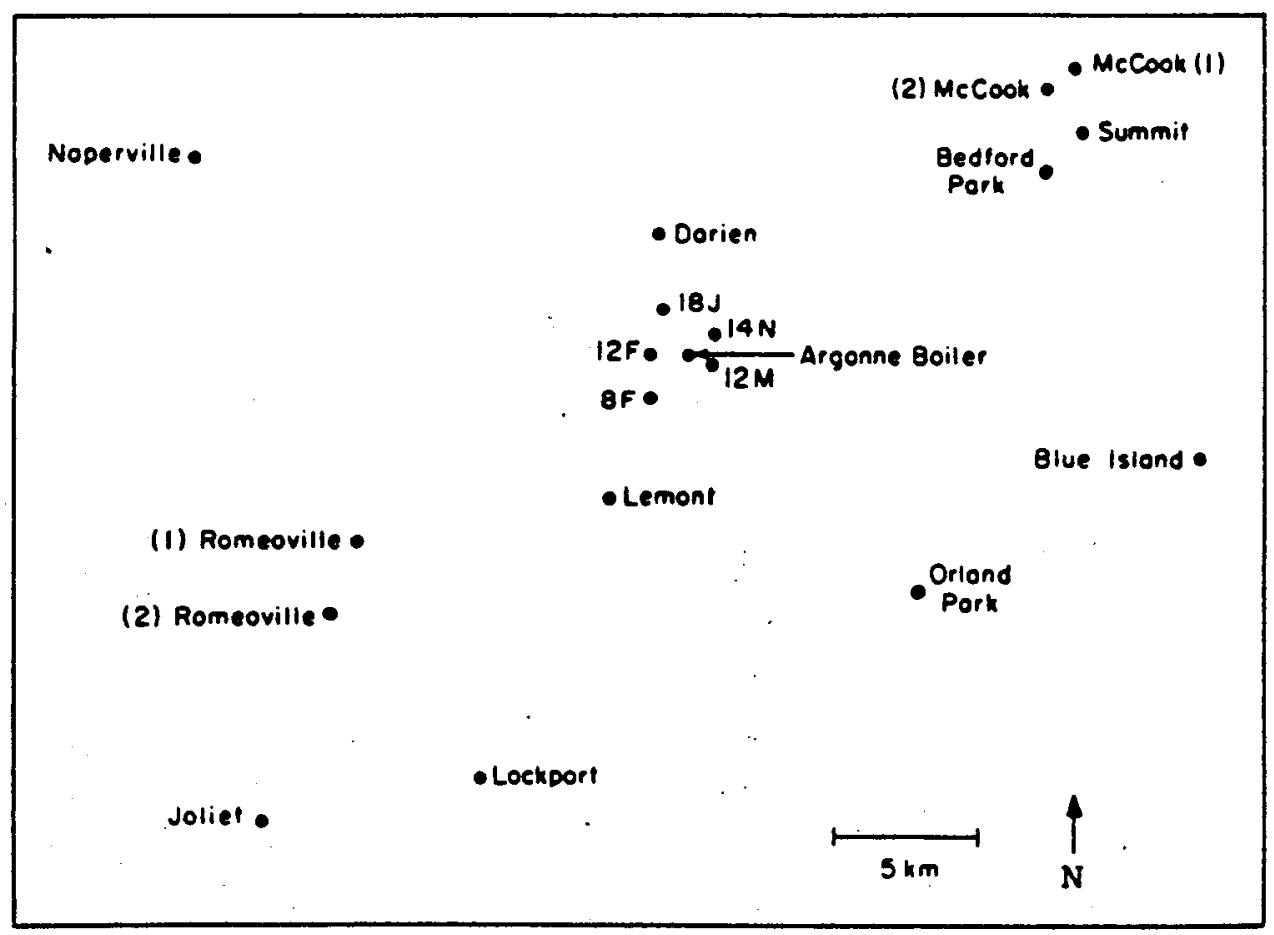

Figure 2.12. Monitoring-Station Locations Surrounding ANL. 
Table 2.6. Summary of National and Illinois Ambient Air Quality Standards ${ }^{a}$

\begin{tabular}{|c|c|c|c|}
\hline Pollutant & Time of Average ${ }^{b}$ & $\begin{array}{c}\text { Primary Standard } \\
\left(\text { at } 25^{\circ} \mathrm{C} \text { and }\right. \\
760 \mathrm{~mm} \text { of } \mathrm{Hg} \text { ) }\end{array}$ & Secondary \\
\hline Particulate matter (TSP) & $\begin{array}{l}\text { Annual geometric mean } \\
24 \text {-hour geometric mean }\end{array}$ & $\begin{array}{r}75 \mu \mathrm{g} / \mathrm{m}^{3} \\
260 \mu \mathrm{g} / \mathrm{m}^{3}\end{array}$ & $\begin{array}{r}60 \mu \mathrm{\mu g} / \mathrm{m}^{3} \\
150 \mu \mathrm{\mu g} / \mathrm{m}^{3}\end{array}$ \\
\hline Sulfur dioxide $\left(\mathrm{SO}_{2}\right)$ & $\begin{array}{l}\text { Annual arithmetic mean } \\
24 \text {-hour arithmetic mean } \\
\text { 3-hour arithmetic mean }\end{array}$ & $\begin{array}{l}0.03 \mathrm{ppm}\left(80 \mu \mathrm{g} / \mathrm{m}^{3}\right) \\
0.14 \mathrm{ppm}\left(365 \mu \mathrm{g} / \mathrm{m}^{3}\right) \\
\text { None }\end{array}$ & $\begin{array}{l}\text { None } \\
\text { None } \\
0.5 \mathrm{ppm}\left(1300 \mu \mathrm{gg} / \mathrm{m}^{3}\right)\end{array}$ \\
\hline Carbon monoxide (C0) & $\begin{array}{l}8 \text { hours } \\
1 \text { hour }\end{array}$ & $\begin{array}{r}9 \mathrm{ppm}\left(10 \mu \mathrm{g} / \mathrm{m}^{3}\right) \\
35 \mathrm{ppm}\left(40 \mu \mathrm{g} / \mathrm{m}^{3}\right)\end{array}$ & $\begin{array}{l}\text { Same as primary } \\
\text { Same as primary }\end{array}$ \\
\hline $\begin{array}{l}\text { Photochemical } \\
\text { oxidants }\left(\mathrm{O}_{3}\right)\end{array}$ & $\begin{array}{l}1 \text { hour (state) } \\
1 \text { hour/day (federal) }\end{array}$ & $\begin{array}{l}0.08 \mathrm{ppm}\left(160 \mu \mathrm{g} / \mathrm{m}^{3}\right) \\
0.12 \mathrm{ppm}\left(235 \mu \mathrm{g} / \mathrm{m}^{3}\right)\end{array}$ & $\begin{array}{l}\text { Same as primary } \\
\text { Same as primary }\end{array}$ \\
\hline $\begin{array}{l}\text { Non-methane } \\
\text { hydroca rbons (N-MHC) }\end{array}$ & 3 hours (6 to 9 a.m.) & $0.24 \mathrm{ppm}\left(160 \mu \mathrm{g} / \mathrm{m}^{3}\right)$ & Same as primary \\
\hline Nitrogen dioxide $\left(\mathrm{NO}_{2}\right)$ & Annual arithmetic mean & $0.05 \mathrm{ppm}\left(100 \mu \mathrm{g} / \mathrm{m}^{3}\right)$ & Same as primary \\
\hline Lead $(\mathrm{Pb})$ & Quarterly arithmetic mean & $1.5 \mu \mathrm{g} / \mathrm{m}^{3}$ & Same as primary \\
\hline
\end{tabular}

${ }^{a}$ Illinois standards are identical to national standards, with the exception of lead for which no state standard exists.

${ }^{b}$ Ali standards with averaging times of 24 hours or less are not to be exceeded more than once per year.

Source: Argonne National Laboratory (1980a). 
Total-suspended-particulates (TSP) and sulfur dioxide $\left(\mathrm{SO}_{2}\right)$ data for monitoring sites operated by regulatory agencies, ANL, and Commonwealth Edison Company are 1 isted in Tables 2.7 and 2.8 , respectively. Monitors within a $16-\mathrm{km}$ radius were selected to represent the local air quality.

Table 2.7. TSP Data $\left(\mu \mathrm{g} / \mathrm{m}^{3}\right)$ from Monitors Located Within an Approximate $16-\mathrm{km}$ Radius of Argonne National Laboratory

\begin{tabular}{|c|c|c|c|c|c|c|c|c|c|}
\hline \multirow[b]{3}{*}{ Monitor } & \multirow{2}{*}{\multicolumn{3}{|c|}{ Geometric Mean }} & \multicolumn{6}{|c|}{ 24-Hour Maximum } \\
\hline & & & & \multicolumn{2}{|c|}{1977} & \multicolumn{2}{|c|}{1978} & \multicolumn{2}{|c|}{1979} \\
\hline & 1977 & 1978 & 1979 & $1 s t$ & 2nd & $1 s t$ & 2nd & $1 s t$ & 2nd \\
\hline \multicolumn{10}{|c|}{ Cook County and Chicago } \\
\hline Bedford Park & 64 & 61 & 69 & 133 & 126 & 136 & 125 & 235 & 154 \\
\hline Lemont $^{b}$ & $-c$ & 74 & d & 134 & 126 & 489 & 195 & 211 & 208 \\
\hline $\operatorname{McCook}(1)^{a}$ & 110 & 87 & 74 & 209 & 187 & 212 & 145 & 148 & 147 \\
\hline McCook $(2)^{a}$ & 101 & 81 & 70 & 219 & 217 & 171 & 151 & 140 & 131 \\
\hline Orland Park ${ }^{a}$ & 52 & 56 & 66 & 177 & 142 & 189 & 176 & 138 & 127 \\
\hline Summit ${ }^{a}$ & 78 & 80 & 84 & 196 & 186 & 225 & 209 & 194 & 193 \\
\hline \multicolumn{10}{|l|}{ Du Page County } \\
\hline Darien $^{a}$ & - & 69 & 69 & - & - & 195 & 188 & 143 & 135 \\
\hline Naperville $e^{a}$ & 58 & 53 & 60 & 165 & 135 & 135 & 131 & 122 & 119 \\
\hline $8 F^{e}$ & 47 & 48 & 45 & - & - & - & - & - & - \\
\hline $12 F^{e}$ & 58 & 58 & 55 & - & - & - & - & - & - \\
\hline $12 \mathrm{M}^{\mathrm{e}}$ & 43 & 48 & 45 & - & - & - & - & 107 & 71 \\
\hline $14 \mathrm{~N}^{\mathrm{e}}$ & - & 38 & 43 & - & - & - & - & - & - \\
\hline $18 \mathrm{~J}^{\mathrm{e}}$ & 52 & 61 & - & - & - & - & - & - & - \\
\hline \multicolumn{10}{|l|}{ Will County } \\
\hline Lockport & 63 & 53. & 70 & 164 & 157 & 203 & 123 & 214 & 180 \\
\hline Romeoville $(1)^{b}$ & 58 & - & 66 & 160 & 155 & 189 & 162 & 155 & 149 \\
\hline Romeoville (2) ${ }^{a}$ & - & 54 & d & 107 & 90 & 202 & 140 & 156 & 151 \\
\hline
\end{tabular}

${ }^{a}$ Monitor operated by the Illinois Environmental Protection Agency.

${ }^{b}$ Monitor operated by Commonwealth Edison Company.

Hyphen means no data.

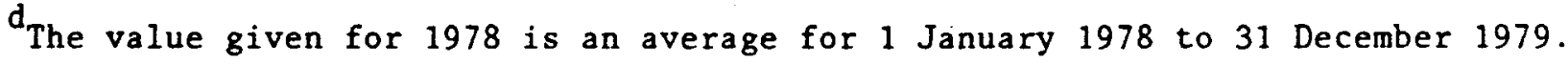

Monitor on the ANL site.

Source: Argonne National Laboratory (1980a). 
Table 2.8. $\mathrm{SO}_{2}$ Data $\left(\mu \mathrm{g} / \mathrm{m}^{3}\right)$ from Continuous Monitors Within an Approximate 16-km Radius of Argonne National Laboratory

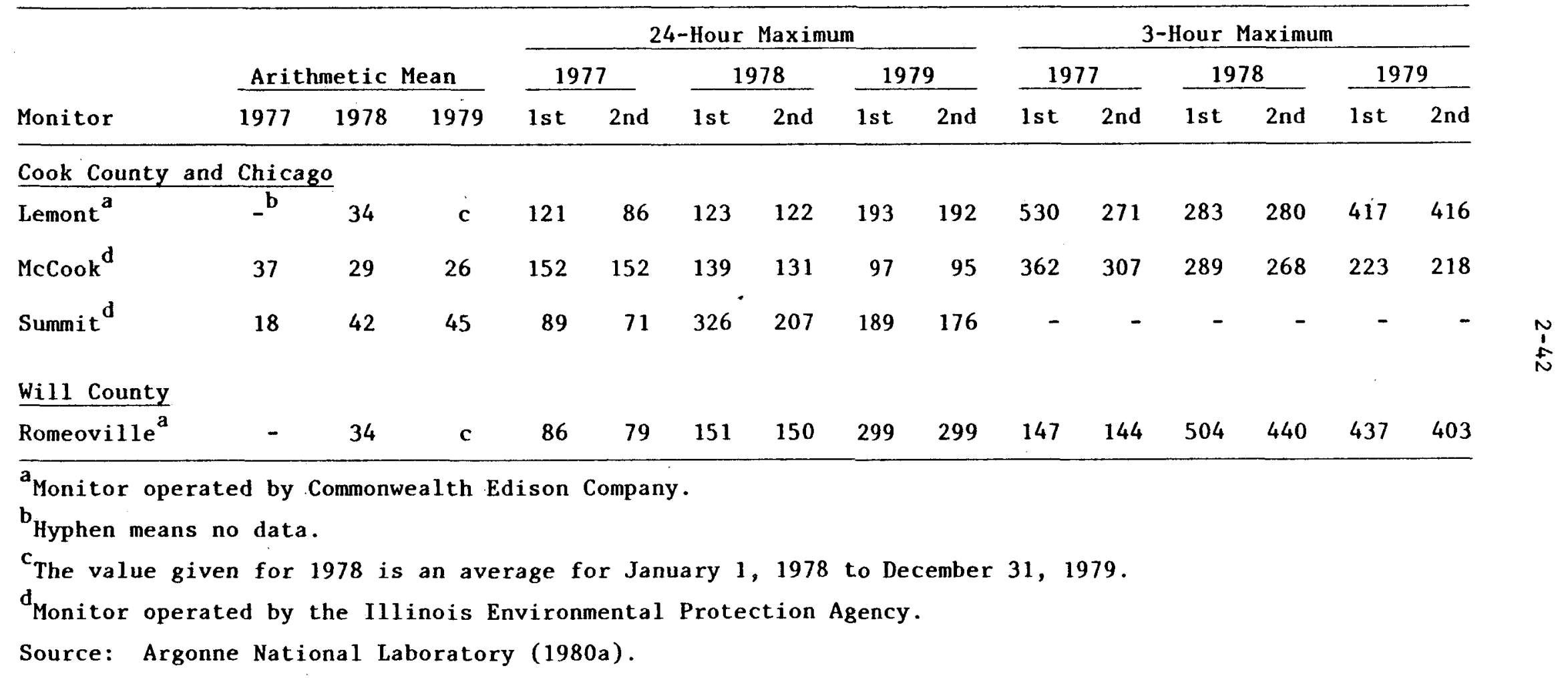


Aside from ANL's monitor sites ( $8 \mathrm{~F}, 12 \mathrm{~F}, 12 \mathrm{M}, 14 \mathrm{~N}, 18 \mathrm{~J})$, Darien and Lemont have the closest monitors. The highest particulate concentrations registered at these offsite monitors were $74 \mu \mathrm{g} / \mathrm{m}^{3}$ for an annual geometric mean and $208 \mu \mathrm{g} / \mathrm{m}^{3}$ for the second-highest 24 -hour average; these values are barely in compliance with primary air-quality standards. The appropriate national and state secondary ambient air-quality standards for TSP are $60 \mu g / \mathrm{m}^{3}$ measured on an annual basis and $150 \mu \mathrm{g} / \mathrm{m}^{3}$ measured on a 24-hour basis. The area does not comply with these figures;.therefore, it is designated "nonattainment" for the secondary TSP air-quality standards.

The McCook and Romeoville TSP monitoring sites are about 12 to $14 \mathrm{~km}$ from ANL, in areas of high particulate generation. Monitoring data from McCook show an annual geometric mean of $110 \mu \mathrm{g} / \mathrm{m}^{3}$ and a second-highest 24-hour maximum of $217 \mathrm{\mu g} / \mathrm{m}^{3}$; for Romeoville, the corresponding values are $66 \mathrm{\mu g} / \mathrm{m}^{3}$ and $162 \mu \mathrm{g} / \mathrm{m}^{3}$, respectively. The TSP level at the McCook monitor is in violation of the primary standard and is more than likely influenced by Metropolitan Chicago/ Cook County industry than by emissions from ANL. Evidence indicates that the TSP level near ANL is the result of fugitive emissions (Golchert et al. 1980).

On the basis of the monitoring results, the Illinois EPA has classified Downers Grove Township (the location of ANL) as nonattainment for secondary TSP standards. Adjacent Lemont Township in Cook County and DuPage Township in Will County are nonattainment for primary TSP standards (U.S. Environ. Prot. Agency 1980).

The maximum measured annual-mean $\mathrm{SO}_{2}$ concentration representative of the air quality at ANL is $45 \mathrm{\mu g} / \mathrm{m}^{3}$, which was recorded at the Summit monitor. Monitoring of $\mathrm{SO}_{2}$ on the laboratory site commenced in June 1980 in compliance with the Delayed Compliance Order issued by the U.S. Environmental Protection Agency. The existing short-term data indicate an average of $17 \mu \mathrm{g} / \mathrm{m}^{3}$ and a maximum 24-hour concentration of $50 \mathrm{\mu g} / \mathrm{m}^{3}$. There are no 3-hour observations. The Lemont monitor reported second-highest 24-hour and 3-hour values of $197 \mu \mathrm{g} / \mathrm{m}^{3}$ and $416 \mu \mathrm{g} / \mathrm{m}^{3}$, respectively, and an annual mean of $34 \mu \mathrm{g} / \mathrm{m}^{3}$. These values are in compliance with air-quality standards.

The nearest nitrogen oxide (NOX) monitor is located in Blue Island, about $20 \mathrm{~km}$ east-southeast. For the calendar years 1977 and 1978 , the annual mean NOx concentrations were $73 \mu \mathrm{g} / \mathrm{m}^{3}$ and $100 \mu \mathrm{g} / \mathrm{m}^{3}$, respectively. The latter figure is equal to the ambient air-quality standard. However, because ANL is located in a more rural area than Blue Island and because recently begun onsite NOx monitoring data seem to indicate a lower ambient concentration $\left(42 \mathrm{\mu g} / \mathrm{m}^{3}\right)$, the above data are not representative of the local air quality. A conservative assumption for the NOx concentration in the vicinity of Argonne is $60 \mathrm{\mu g} / \mathrm{m}^{3}$, which is about the same as Joliet, $25 \mathrm{~km}$ southwest of ANL.

\subsubsection{Water Resources}

\subsubsection{Surface Water}

The major surface stream on the ANL site is Sawmill Creek. The creek originates about $2.5 \mathrm{~km}$ north of the ANL site, enters the site north of the boiler building, flows through the site in a southerly direction, and leaves near the southeast corner. The ANL sewage discharge enters the creek about 
$1 \mathrm{~km}$ south of the fence (outside the ANL site), and the creek joins the Des Plaines River about $300 \mathrm{~m}$ beyond the sewage discharge.

The average annual flow of Sawmill Creek is about $0.3 \mathrm{~m}^{3} / \mathrm{s}$, with extremes of $0.10 \mathrm{~m}^{3} / \mathrm{s}$ and $27.9 \mathrm{~m}^{3} / \mathrm{s}$. About $0.13 \mathrm{~m}^{3} / \mathrm{s}$ of the flow is discharged from the Marion Brook (DuPage County) sewage-treatment plant upstream of ANL. The creek is moderately high in sewage-generated contaminants such as BOD, nutrients, and trace elements and is moderately polluted. The stream is classified as water-quality limited with respect to the dissolved-oxygen level. No major recreational or industrial use is made of the creek, although it does provide scenic values as it flows through the forest preserve below ANL. Some angling and canoeing is reported to take place near the mouth of Sawmill Creek and in the Des Plaines River downstream of the confluence.

Based on Horton's method of stream classification, two small first-order streams that originate onsite combine to form Freund Brook, which discharges into Sawmill Creek. Along the southern margin of the property, the terrain slopes abruptly upward forming forested bluffs. These bluffs are dissected by ravines containing intermittent streams that discharge some site drainage in a southerly direction toward the Des Plaines River.

In addition to the streams, various natural and man-made impoundments, ponds, and cattail marshes are present on the site. The site also has a network of ditches and culverts that transport surface runoff toward the smaller streams. However, the ditches support little aquatic biota and are not considered in this assessment. In February 1982, approximately $1900 \mathrm{~m}^{3}$ of water abruptly drained from an impoundment that had existed for 15 years. Investigation of the incident indicated that the water drained into the Niagara dolomite aquifer.

The greater portion of the ANL site is drained by Freund Brook. Two intermittent branches of Freund Brook flow from west to east, draining the interior portion of the site and ultimately discharging into Sawmill Creek. The larger, south branch originates in a marsh adjacent to the western boundary line of the site. It traverses wooded terrain for a distance of about $2.3 \mathrm{~km}$ to its confluence with Sawmill Creek. The north branch originates in a cattail marsh near the center of the site and flows east for a distance of about $0.7 \mathrm{~km}$ before discharging into the south branch at Lower Freund Pond.

The stream gradients of the north and south branches of Freund Brook are $1.25 \%$ and $2.11 \%$, respectively. The steep gradients of these streams promote rapid runoff and, except for three small man-made impoundments and one natural cattail marsh on the south branch, the habitat is dominated by riffle areas. The substrate in the free-flowing segments of Freund Brook contains coarse rock and gravel distributed on a firm mud base. These streams drain old fields, dense woods, lawns, and parking lots; consequently, their silt load is low compared with Sawnill Creek's, and usually the water has high clarity.

Data on the annual discharge of Freund Brook are not available; however, field observations of the stream size and channel configuration suggest the combined average annual discharge of both branches is less than $0.08 \mathrm{~m}^{3} / \mathrm{s}$. During maximum flood stage, the combined discharge is likely less than $0.6 \mathrm{~m}^{3} / \mathrm{s}$. The periods of high and low flow probably correspond to those of Sawmill Creek. 
The Des Plaines River is the major drainage sink for the region. The flow ranges from 12 to $340 \mathrm{~m}^{3} / \mathrm{s}$, with a generally poor water quality due to industrial and sewage effluents.

\subsubsection{Groundwater}

There are two principal aquifers used as water supplies in the ANL area. The upper aquifer is the Niagara-Alexandrian dolomite with the piezometric surface now between $15 \mathrm{~m}$ and $30 \mathrm{~m}$ below the ground surface over much of the site. The lower aquifer is the Galesville sandstone, a part of the CambrianOrdivician aquifer, which lies between $150 \mathrm{~m}$ and $450 \mathrm{~m}$ below the surface.

The four ANL wells now in use are $90 \mathrm{~m}$ deep in the Niagara dolomite and have yields of 1300 to $1900 \mathrm{~L} / \mathrm{min}$. One unused well is in the Galesville sandstone and is $490 \mathrm{~m}$ deep. However, the water table has dropped below the pumping level and the well is no longer usable. The water level in the Niagara dolomite has remained reasonably stable under ANL pumping of about $3800 \mathrm{~m}^{3} / \mathrm{d}$, dropping $1.5 \mathrm{~m}$ between 1960 and 1970. Currently, the aquifer appears adequate for future ANL use; however, recent heavy suburban development in the site area may cause substantial declines in the water level.

\subsubsection{Cultural Resources}

A cultural resource survey was made on part of the ANL property and 18 prehistoric and 3 historic sites were identified. Figure 2.13 shows the areas of the Laboratory that had been surveyed as of Summer 1981 and the spacing of the field transect lines along which shovel tests were made to locate unknown sites. A shovel testing approach was selected for sampling the surface and subsurface soils because a dense vegetational cover obscured the ground surface and because most of the ANL soils are relatively shallow. Backhoe trenching

was limited to testing one study area where soils were deeper (see Figure 2.13). Surveys were made in the undeveloped areas of the Laboratory and in areas scheduled for future construction projects. The size of transect lines was varied in order to test the effectiveness of different survey strategies under similar vegetational conditions. It was determined that transect spacings wider than $15 \mathrm{~m}$ were ineffective and that transects spaced at $7.5 \mathrm{~m}$ or less should be used in the areas most likely to contain cultural resource sites. Consequently, the surveyed areas with transects spaced apart more than $7.5 \mathrm{~m}$ that are identified in Figure 2.13 should be considered incomplete.

Limited test excavations were made at 5 of the 18 prehistoric sites that have been identified to date. From the lithic materials observed in test squares, in the shovel tests, and in private surface collections, similarities in chronology and function were observed among many of the sites. Results of these studies are summarized in a field report (Curtis and Berlin 1980). Sites tend to occur. in clusters and to have functioned for lithic tool making and remanufacturing activities during the late Middle Archaic and early Late Archaic Periods. More information must be collected about the boundaries, structure, and function of the individual prehistoric sites before a complete evaluation can be made for determining their eligibility status for monimation to the National Register of Historic Places. However, based on a preliminary analysis, some or all sites may be potentially eligible for nomination as a District. The State of Illinois Chief Staff Archaeologist concurs (Downer 1980). 


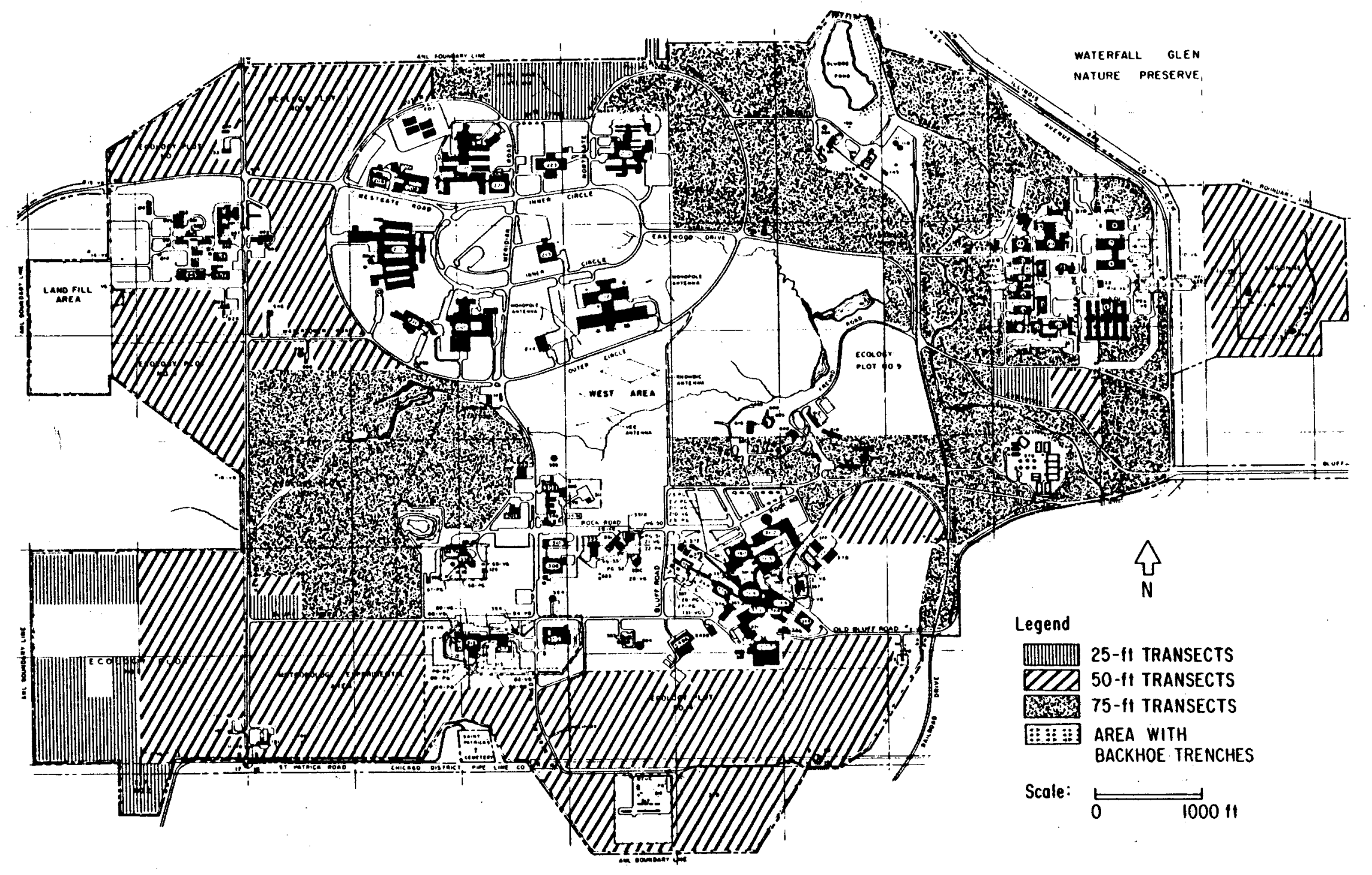

Figure 2.13. Area Surveyed From 1978 Through 1981 by Shovel Testing. 
Numerous historic homesteads were once located on ANL property although the remains of only three properties have been identified at this time (Curtis and Berlin 1980). No study or evaluation has been made of these historic properties. It is the Laboratory's policy to protect all cultural or historic resources (Argonne Nat1. Lab. 1982).

\section{$2.2 .8 \quad$ Ecology}

This section describes the terrestrial and aquatic ecology of the ANL site. In particular, the flora and fauna of the area are discussed in relation to their respective habitats.

\subsubsection{Terrestrial Ecology}

The ANL site lies within the Prairie Peninsula Section of the Oak-Hickory Forest Region. The prairie peninsula is a mosaic of oak forest, oak openings, and tall-grass prairie occurring on glaciated parts of Illinois, northwest Indiana, southern Wisconsin, and parts of other states. It is an anomaly in plant biogeography because it lies east of the forest-prairie border that follows the $760-\mathrm{mm}$ precipitation line. Also, the local distributions of prairie and oak-forest stands throughout the region do not seem to correlate consistently with other factors such as soil type and drainage.

Based on an early aerial photograph of the site, it appears that most of the land was once actively farmed. About $75 \%$ was plowed fields and $25 \%$ grazed open oak woodlots and oak forests. Starting in 1953 and continuing over three seasons, some of the formerly cultivated fields were planted with $j a c k$, white, and red pine trees (Pinus banksiana, $\underline{P}$. strobus, and $\underline{P}$. resinosa). Several of these pine plantations are located on the north-northwestern periphery of the site; others are located near the southwestern and southeastern peripheries and at Argonne Park.

Most of the remaining fields are currently in various stages of old field succession. They are dominated by bluegrass (Poa spp.), various forbs (including yarrow, Queen-Anne's-lace, goldenrod, asters, bindweed, cress), and in some areas by dense plots of crown vetch.

The deciduous forests on the remainder of the site are dominated by various species of oak (bur oak, Quercus macrocarpa; white oak, $Q$. alba; red oak, Q. rubra; and black oak, Q. velutina). Tree species commonly associated with the oaks include: hickory (Carya ovata and $\underline{C}$. cordiformis), hawthorne (Crataegus spp.), cherry (Prunus spp.), and ash (Fraxinus spp.). Crown vetch (Caronilla varia sp.) has been planted on much of the developed area since 1954 to help control soil erosion and provide a low-maintenance ground cover. It is a very vigorous perennial legume which forms dense mats that inhibit invasion by other species.

The mixture of vegetational communities (open fields, deciduous forests, pine plantations, wetlands, and mowed rights-of-way), coupled with a large degree of protection from human intrusion, makes the ANL site an effective refuge for many species of animals. The birds, mammals, and reptiles and amphibians commonly observed or likely to occur on the site are listed in Tables $2.9,2.10$, and 2.11 , respectively. These animals are characteristically found in open fields, forests, and forest-edge communities in the 
Table 2.9. Birds Commonly Observed on the ANL Sitea

\begin{tabular}{|c|c|}
\hline Summer Residents & Winter Residents \\
\hline $\begin{array}{l}+ \text { Starling } \\
+ \text { House sparrow } \\
+ \text { Common crow } \\
+ \text { Mallard } \\
+ \text { Blue jay } \\
+ \text { Black-capped chickadee } \\
+ \text { Sparrows (song, field, chipping) } \\
\text { Woodpeckers (hairy, downy, red- } \\
\text { bellied, redheaded, common } \\
\text { flicker) } \\
\text { Redtailed hawk } \\
\text { American kestrel } \\
\text { American goldfinch } \\
\text { Cardinal } \\
+ \text { Grackle } \\
\text { Rock dove (pigeon) } \\
\text { Kingfisher } \\
\text { Horned lark } \\
+ \text { Robin } \\
+ \text { Swallows (barn, rough-winged, } \\
\text { tree, purple martin) } \\
\text { Warblers (yellowthroat) } \\
\text { Indigo bunting } \\
\text { Common oriole } \\
\text { Chimney swift } \\
\text { Western meadowlark } \\
\text { Nighthawk } \\
\text { Brown-headed cowbird } \\
\text { Rufous-sided towhee } \\
\text { Brown thrasher } \\
\text { Eastern kingbird } \\
\text { Rose-breasted grosbeak } \\
+ \text { Red-winged blackbird } \\
\text { Catbird } \\
\text { Killdeer } \\
\text { Mourning dove } \\
\text { Mute swans } \\
\text { Pheasant }\end{array}$ & $\begin{array}{l}\text { + Starling } \\
+ \text { House sparrow } \\
+ \text { Common crow } \\
+ \text { Mallard } \\
+ \text { Blue jay } \\
+ \text { Black-capped chickadee } \\
+ \text { Sparrows (song, tree) } \\
\text { Woodpeckers (hairy, downy, red- } \\
\text { bellied, redheaded) } \\
\text { Redtailed hawk } \\
\text { American kestrel } \\
\text { American goldfinch } \\
\text { Cardinal } \\
\text { Grackle } \\
\text { Rock dove (pigeon) } \\
\text { Kingfisher } \\
\text { Horned lark } \\
+ \text { Dark-eyed junco } \\
\text { Mute swans } \\
\text { Wild turkey }\end{array}$ \\
\hline
\end{tabular}

a The symbol $+=$ most numerous. 
Table 2.10. Mammals Commonly Observed or Likely to Occur on the ANL Site

\begin{tabular}{ll}
\hline \multicolumn{1}{c}{ Common Name } & \multicolumn{1}{c}{ Common Name } \\
\hline Fallow deer & Norway rat \\
Eastern cottontail rabbit & Short-tailed shrew \\
Opossum & Voles (meadow, prairie) \\
Raccoon & Fox (gray, red) \\
Striped skunk & Muskrat \\
Woodchuck & Eastern chipmunk \\
Mice (white-footed, deer, & Eastern mole \\
meadow jumping, house) & Weasel \\
Squirrel (fox, gray) & Brown bat \\
13-lined ground squirrel & Beaver \\
\hline
\end{tabular}

Table 2.11. Reptiles and Amphibians Commonly Observed or Likely to Occur on the ANL Site

\begin{tabular}{ll}
\hline \multicolumn{1}{c}{ Reptiles } & \multicolumn{1}{c}{ Amphibians } \\
\hline Fox snake & Tiger salamander \\
Garter snake & Tree frog \\
Water snake & Bull frog \\
DeKay's snake & Leopard frog \\
Mud turtle & Spring peeper \\
Box turtle & \\
Gopher turtle & \\
\hline
\end{tabular}


Midwest. Also, other bird species use the ANL site as a stopover during spring and fall migrations.

By far the most numerous animals on the site are the small invertebrates, including segmented worms (annelids), roundworms (nematodes), insects (beetles, grasshoppers, flies, bees, wasps, moths, butterflies, true bugs, leaf hoppers, crickets, mosquitoes, etc.), spiders (arachnids), daddy-long-legs (phalangids), mites (acari), centipedes (chilopods), and millipedes (diplopods).

The site is inhabited by a herd of approximately 400 fallow deer (Dama dama), an exotic species imported from Europe. Although fallow deer have several color varieties, only the white variety occurs at Argonne. The herd has grown from a few deer left behind on the Freund estate in 1947 when the federal government acquired the site to a current population of more than 400 head. Most of the fallow deer are inside the perimeter fence. However, over the past several years there has been a large increase in the number found outside the fence in the forest preserve. Deer trails within the herd's range are becoming much more pronounced, and evidence of deer browse is becoming more frequent and distinct. A more detailed discussion of fallow deer is given in Appendix $C$.

\subsubsection{Aquatic Ecology}

The aquatic resources of the ANL site are diverse. In addition to streams and man-made impoundments, the site also has a network of ditches to transport runoff. Inasmuch as the ditches support little aquatic biota other than macrophytes, primarily cattails, they are not addressed here. A list of the aquatic macrophytes observed at ANL is presented in Table 2.12. Algae identified in onsite aquatic habitats are listed in Tables 2.13 and 2.14 .

The major portion of the site is drained by Freund Brook, which is formed by two intermittent branches. The gradient of the stream is relatively steep, and riffle habitat predominates. The substrate is coarse rock and gravel on a firm mud base. Primary production in the stream is limited by shading, but diatoms and some filamentous algae are common. Invertebrate fauna consist primarily of dipteran larvae, crayfish, caddisfly larvae, and midge larvae. Few fish are present due to the low summer flows and high temperatures. Freund Brook is impounded three times within less than one kilometer upstream from its confluence with Sawmill Creek. The three impoundments follow one after the other and progressively increase in size and depth and diversity of aquatic biota. The upstream pond is small, shallow, and almost silted in. Fish are rare, but macrophytes such as giant bulrush, water plantain, and other rushes are present. The middle impoundment is primarily open water with a small littoral zone. Waterfowl (i.e., ducks and swans) use this pond, and other than an occasional "bloom" of duckweed, macrophytes are rare. Primary producers are algae. This pond contains greater algal biomass than the other two impoundments, probably due to the nutrient inputs from the resident waterfowl. The pond has not been sampled, but sunfishes and minnows have been observed. The lower impoundment has a small littoral zone inhabited by cattails, rushes, and other macrophytes. Observations have shown the fish community to be dominated by sunfish, with a few species of minnows also present.

Upstream of Upper Freund Pond on the south branch of Freund Brook, there is a 1.4-ha area of small ponds surrounded by extensive cattail marshes and 
Table 2.12. Aquatic and Marsh Macrophytes of ANL

\begin{tabular}{|c|c|c|}
\hline Plant & Common Name & Location \\
\hline $\begin{array}{l}\text { Nymphaeaceae } \\
\text { Nuphar sp. }\end{array}$ & Pond lily & Sawmill Creek \\
\hline $\begin{array}{l}\text { Ceratophyllaceae } \\
\text { Ceratophyllum demersum } \mathrm{L} .\end{array}$ & Coontail & Gas Station Ponds \\
\hline $\begin{array}{l}\text { Alismaceae } \\
\text { Alisma subcordatum Raf. } \\
\text { Sagittaria latifolia L. } \\
\text { Sagittaria graminae }\end{array}$ & $\begin{array}{l}\text { Water plantain } \\
\text { Common arrow- } \\
\text { head } \\
\text { Grass-leaved } \\
\quad \text { arrowhead }\end{array}$ & $\begin{array}{l}\text { Upper Freund Pond } \\
\text { Freund Brook, } \\
\text { Sawmill Creek } \\
\mathrm{NA}^{\mathrm{a}}\end{array}$ \\
\hline $\begin{array}{l}\text { Potamogetonaceae } \\
\text { Potamogeton spp. } \\
\text { Potamogeton americanus C. and S. (?) } \\
\text { Potamogeton nodosus Poir. (?) }\end{array}$ & Pondweeds & $\begin{array}{l}\text { Sawmill Creek, } \\
\text { Gas Station Ponds } \\
\text { Sawmill Creek } \\
\text { Sawmill Creek, } \\
\text { Freund Brook }\end{array}$ \\
\hline $\begin{array}{l}\text { Lemnaceae } \\
\text { Lemna minor L. }\end{array}$ & Duckweed & $\begin{array}{l}\text { Sawmill Creek, } \\
\text { Freund Brook, } \\
\text { Upper Freund Pond }\end{array}$ \\
\hline $\begin{array}{l}\text { Typhaceae } \\
\text { Typha latifolia L. } \\
\text { Typha glauca Godr. }\end{array}$ & Cattails & $\begin{array}{l}\text { Ubiquitous } \\
\text { NA }\end{array}$ \\
\hline $\begin{array}{l}\text { Sparganiaceae } \\
\text { Sparganium eurycarpum Engelm. }\end{array}$ & Giant bur reed & NA \\
\hline $\begin{array}{l}\text { Graminae } \\
\text { Phragmites communis Trin. }\end{array}$ & Giant reed & NA \\
\hline $\begin{array}{l}\text { Cyperaceae } \\
\text { Eleocharis sp. } \\
\text { Cyperus strigosus L. } \\
\text { Scirpus } \\
\text { Spirpus } \\
\text { Scirpus } \\
\text { atrovirens Muhl. }\end{array}$ & $\begin{array}{l}\text { Spike rush } \\
\text { Lean sedge } \\
\text { Bulrush }\end{array}$ & $\begin{array}{l}\text { Sawmill Creek } \\
\text { Sawmill Creek } \\
\text { Upper Freund Pond } \\
\text { Freund Brook } \\
\text { NA }\end{array}$ \\
\hline $\begin{array}{l}\text { Juncaceae } \\
\text { Juncus sp. } \\
\text { Juncus tenuis Willd. }\end{array}$ & Roadside rush & $\begin{array}{l}\text { Upper Freund Pond } \\
\text { NA }\end{array}$ \\
\hline $\begin{array}{l}\text { Iridaceae } \\
\text { Iris sp. }\end{array}$ & & Freund Brook \\
\hline
\end{tabular}


Table 2.13. Composition and Abundance of Algae in the Plankton of ANL Habitats

\begin{tabular}{|c|c|c|c|c|c|c|c|}
\hline \multirow[b]{3}{*}{ Organism } & \multirow{3}{*}{$\frac{\text { Sawmill }}{\mathrm{Sl}}$} & \multirow{3}{*}{$\frac{\text { Creek }^{\mathrm{b}}}{\mathrm{s} 2}$} & \multirow{2}{*}{\multicolumn{2}{|c|}{ (20Sep78) }} & \multicolumn{3}{|c|}{ Other Habitats (25Sep78) } \\
\hline & & & & & \multirow{2}{*}{$\begin{array}{l}\text { Sludge } \\
\text { Pond }\end{array}$} & \multirow{2}{*}{$\begin{array}{l}\text { Gas } \\
\text { Station } \\
\text { Ponds }\end{array}$} & \multirow{2}{*}{$\begin{array}{c}\text { Middle } \\
\text { Freund } \\
\text { Pond }\end{array}$} \\
\hline & & & s3 & S4 & & & \\
\hline \multicolumn{8}{|l|}{ Cyanophyta } \\
\hline Undet. bluegreens & & & & & 72 & 1,500 & \\
\hline $\begin{array}{l}\text { Chroococcus sp. } \\
\text { Anabaena sp. }\end{array}$ & 63,000 & & & $\cdot$ & $+c$ & & \\
\hline \multicolumn{8}{|l|}{ Chlorophyta } \\
\hline Undet. greens & & & & & + & 6,000 & \\
\hline Eudorina elegans Ehrenberg & & & 9 & & & 750 & \\
\hline Sphaerocystis schroeteri Chodat & & + & & + & & 750 & 7,100 \\
\hline Asterococcus spinosus Prescott & & & & & & + & \\
\hline Pediastrum boryanum (Turp.) Meneghini & & & & & + & & \\
\hline Pediastrum duplex Meyer & & & & & & 750 & 7,100 \\
\hline Treubaria setigerum (Archer) G. M. Smith & + & & & & + & & \\
\hline $\begin{array}{l}\text { Oocystis } \\
\text { Ankistrodesmus falcatus (Corda) Ralfs }\end{array}$ & & + & + & $\begin{array}{l}4 \\
4\end{array}$ & & & \\
\hline Shroederia setigera (Schroed.) Lemmermann & & & & 4 & & 750 & \\
\hline Tetraedron caudatum (Corda) Hansgirg & & & & & & 750 & \\
\hline Scenedesmus arcuatus Lemmermann & & & & & & 750 & \\
\hline Scenedesmus dimorphus (Turp.) Kuetz. & & & & 4 & & & \\
\hline Scenedesmus hystrix Langerheim & & & & & & 750 & \\
\hline Scenedesmus quadricauda (Turp.) de Brebisson & & & & & & 2,200 & 7,100 \\
\hline Crucigenia rectangularis (A. Braun) Gay & & & & & & & 43,000 \\
\hline Cosmarium sp. & & & & & + & 750 & \\
\hline Closterium acerosum (Schrank) Ehrenberg & + & & & & & & \\
\hline $\begin{array}{l}\text { Xanthophyta } \\
\text { Arachnochloris minor Pascher } \\
\text { Ophiocytium elongatum West \& West }\end{array}$ & & & & & & $\begin{array}{r}1,500 \\
750\end{array}$ & \\
\hline
\end{tabular}


Table 2.13. Continued

\begin{tabular}{|c|c|c|c|c|c|c|c|}
\hline \multirow[b]{3}{*}{ Organism } & \multirow{3}{*}{$\frac{\text { Sawmill }}{\mathrm{s} 1}$} & \multirow[b]{2}{*}{ Creek $^{\mathbf{b}}$} & \multirow{2}{*}{\multicolumn{2}{|c|}{$(20 \operatorname{Sep} 78)$}} & \multicolumn{3}{|c|}{ Other Habitats (25Sep 78$)$} \\
\hline & & & & & \multirow{2}{*}{$\begin{array}{l}\text { Sludge } \\
\text { Pond }\end{array}$} & \multirow{2}{*}{$\begin{array}{l}\text { Gas } \\
\text { Station } \\
\text { Ponds }\end{array}$} & \multirow{2}{*}{$\begin{array}{l}\text { Middle } \\
\text { Freund } \\
\text { Pond }\end{array}$} \\
\hline & & $\mathrm{S} 2$ & S3 & 54 & & & \\
\hline \multicolumn{8}{|l|}{ Bacillariophyta } \\
\hline Cyclotella sp. & & + & + & & & 2,200 & 260,000 \\
\hline Undet. pinnate diatoms & & & & & 18 & 3,000 & 7,000 \\
\hline Fragilaria sp. & 9 & & & & & & \\
\hline$\overline{\text { Navicula sp }}$ & & + & & 9 & & & \\
\hline Gomphonema parvulum Kuetz. & 22 & 4 & & & & & \\
\hline $\begin{array}{l}\text { Nitzschia sp. } \\
\text { Suriella sp. }\end{array}$ & $\begin{array}{l}4 \\
4\end{array}$ & & + & & + & & \\
\hline Chrysophyta & & & & . & & & - \\
\hline Dinobryon sertularia Ehrenberg & & & & & & 7,000 & \\
\hline \multicolumn{8}{|l|}{ Pyrrophyta } \\
\hline Glenodinium sp. & & & & & & & 7,000 \\
\hline \multicolumn{8}{|l|}{ Euglenophyta } \\
\hline Phacus sp. & & & + & & & & \\
\hline Trachelomonas sp. & & & & & & 750 & \\
\hline \multicolumn{8}{|l|}{ Cryptophyta } \\
\hline Undet. flagellates & 22 & 22 & 36 & 13 & 4 & 13,000 & 150,000 \\
\hline Cryptomonas sp. & & & & & & 750 & \\
\hline Rhodomonas sp. & & & & & & 3,000 & \\
\hline Total & 63,000 & 26 & 45 & 38 & 94 & 48,000 & 490,000 \\
\hline
\end{tabular}

${ }^{a}$ Figures are number of cells or colonies/mL to two significant digits.

$\mathrm{b}_{\mathrm{S} 1}=$ Sampling Station 1 (16K); S2 (11L); S3 (10M); S4 (6N); for locations, see Figure 2.11.

$\mathrm{c}_{\text {The symbol }}+=$ present but too few to enumerate. 
Table 2.14. Algae Identified from the Periphyton in Sawmill Creek Aquatic Habitats, September 20, 1978

\begin{tabular}{|c|c|c|c|c|}
\hline \multirow[b]{2}{*}{ Organism } & \multicolumn{4}{|c|}{ Sampling Station ${ }^{a}$} \\
\hline & $\mathrm{Sl}$ & $\mathrm{S} 2$ & S3 & S4 \\
\hline $\begin{array}{l}\text { Cyanophyta } \\
\text { Undet. coccoid bluegreens }\end{array}$ & & & & $+t^{b}$ \\
\hline $\begin{array}{l}\text { Chlorophyta } \\
\text { Undet. coccoid greens } \\
\text { Rhizoclonium Hieroglyphicum (C. A. Ag.) Kuetz. } \\
\text { Characium pringsheimii A. Braun } \\
\text { Hydrodictyon reticulatum (L.) Langerheim } \\
\text { Spirogyra sp. }\end{array}$ & $\begin{array}{l}+ \\
+ \\
+ \\
+\end{array}$ & + & $\begin{array}{l}+ \\
+\end{array}$ & + \\
\hline 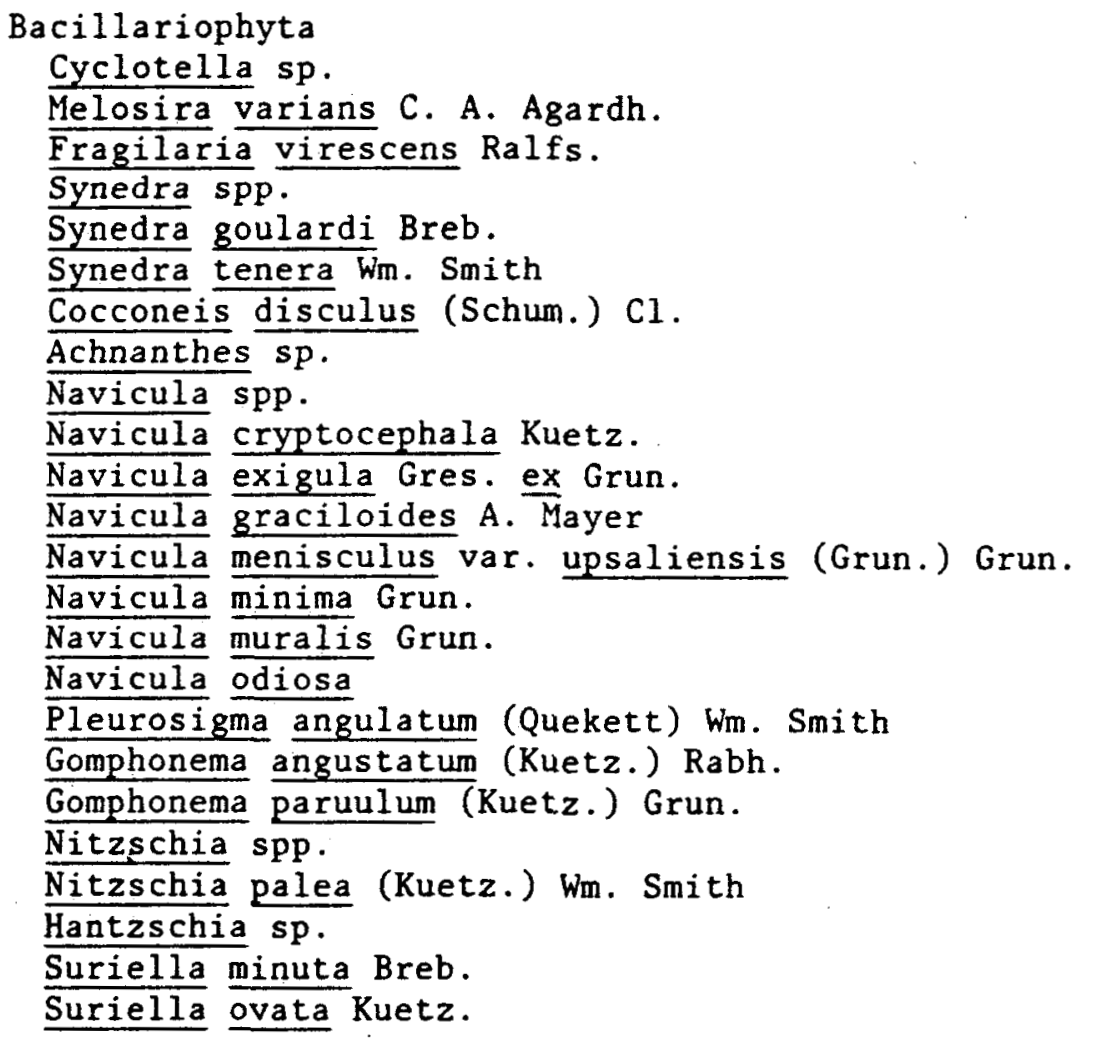 & $\begin{array}{l}+ \\
+\end{array}$ & $\begin{array}{l}+ \\
+\end{array}$ & $\begin{array}{l}+ \\
+ \\
+ \\
+ \\
+ \\
+\end{array}$ & $\begin{array}{l}+ \\
+\end{array}$ \\
\hline $\begin{array}{l}\text { Chrysophyta } \\
\text { Mallomonas sp. } \\
\text { Number of Species }\end{array}$ & $\begin{array}{l}- \\
13\end{array}$ & $\begin{array}{r}+ \\
-- \\
10\end{array}$ & $\begin{array}{l}-- \\
17\end{array}$ & -7 \\
\hline
\end{tabular}


wooded swamp habitat. This system is referred to as the Gas Station Ponds. The area is shaded by mature oaks and willows. About one-fourth of the area is open water; the remainder is marsh and swamp. The area constantly contains water and provides excellent year-round habitat for aquatic biota such as muskrat and waterfowl. Sources of organic matter for secondary production in this system are terrestrial leaf litter and cattail in addition to a productive phytoplankton community.

There are three small cattail marshes on the southwest portion of the site, each less than 0.04 ha in area, that contain sufficient water during spring to produce emergent aquatic vegetation. At maximum water level, these ponds discharge into the uppermost reach of Freund Brook. During dry periods of the year (usually fall), these marshes are dry. All of these marshes contain a rather varied aquatic flora that provides nesting habitat and food for muskrat and waterfowl.

The ANI site is encompassed by the Waterfall Glen Nature Preserve (administered by DuPage County). Because of this proximity, there is a high degree of hydrologic interconnection between the two areas. Wetland habitats of the preserve are variable in size and character, but are generally similar to onsite cattail marshes. The adjacent offsite wetlands range from small, mesic swales with entrenched drainageways to extensive lowland areas with standing water.

A man-made aquatic habitat exists near the boiler plant. It consists of a 2.8-ha sludge pond that primarily receives water-softening wastes (lime) from the site water-treatment plant. The sludge pond is quite shallow--in most places, only a few centimeters above the settled carbonate-rich sludge. The high pH of the water excludes most biota; however, some phytoplankton do occur, primarily blue-green algae, pennate diatoms, and flagellates. Solid substrates are occasionally covered by mats of blue-green algae, and the pond is encircled by a narrow band of cattails. A few aquatic reptiles and amphibians have been observed in the pond, and it has been intermittently used by waterfowl.

The biota of Sawmill Creek reflect its high silt load, steep gradient, and sewage effluent from the Marion Brook (DuPage County) sewage-treatment plant upstream of ANL. Primary production is high due to nutrients supplied from sewage effluent and organic matter from watershed drainage. Dense periphytic algal growth occurs on much of the rocky substrate. Periphyton are dominated by filamentous green algae with a diverse assemblage of diatoms. Phytoplankton are primarily green algae and diatoms. The macroinvertebrate community of Sawmill Creek is characteristic of streams receiving organic pollution (Table 2.15). The fauna is not diverse and primarily contains blackflies, midges, isopods, flatworms, and segmented worms. Clean-water invertebrates, e.g., mayflies and stoneflies, are rare or conspicuously absent. The fish community of the stream indicates similar conditions. Creek chubs greatly dominate the depauperate community, which consists of a few species of minnows, sunfishes, and catfish. Fish found in onsite aquatic habitats are listed in Table 2.16 . 
Table 2.15. Macroinvertebrate Species Collected from Sawmill Creek, September 20, 1978

\begin{tabular}{|c|c|c|c|}
\hline \multirow[b]{2}{*}{ Species } & \multicolumn{3}{|c|}{ Sampling Station ${ }^{a}$} \\
\hline & SI & S3 & S4 \\
\hline \multicolumn{4}{|l|}{ Annelida } \\
\hline \multicolumn{4}{|l|}{ Oligocheata } \\
\hline $\begin{array}{l}\text { Tubificidae } \\
\text { Tubifex tubifex }\end{array}$ & $+b$ & + & + \\
\hline \multicolumn{4}{|l|}{$\begin{array}{l}\text { Turbellaria } \\
\text { Tricladida }\end{array}$} \\
\hline Planariidae & & & \\
\hline Dugesia tigrina & + & + & + \\
\hline \multicolumn{4}{|l|}{ Hirudinea } \\
\hline \multicolumn{3}{|l|}{ Arhynchobdellida } & \\
\hline \multicolumn{4}{|l|}{ Eucrustacea } \\
\hline \multicolumn{4}{|l|}{ Isopoda } \\
\hline Asellus intermedius & + & + & + \\
\hline \multicolumn{4}{|l|}{ Insecta } \\
\hline \multicolumn{4}{|l|}{ Coleoptera } \\
\hline Stenelmis douglasensis & + & + & + \\
\hline \multicolumn{4}{|l|}{ Diptera } \\
\hline Chironominae & $\cdot$ & & \\
\hline Chironomus sp. & + & + & \\
\hline Dicrotendipes sp. & & + & + \\
\hline$\overline{\text { Polypedilum sp. }}$ & + & + & + \\
\hline Cricotopus sp. & + & + & + \\
\hline Eukiefferiella sp: & & & + \\
\hline Psectrocladius sp. & & + & \\
\hline Thienemanniella sp. & & + & + \\
\hline Tanypodinae & & & \\
\hline Ablabesmyia sp. & + & + & + \\
\hline Psectrotanypus sp. & + & & \\
\hline $\begin{array}{l}\text { Empididae } \\
\text { Simuliddae }\end{array}$ & + & + & + \\
\hline $\begin{array}{l}\text { Simuliidae } \\
\text { Simulium vittatum }\end{array}$ & + & + & + \\
\hline Tipulidae & & & \\
\hline Limonia sp. & + & & + \\
\hline Tipula sp. & & + & + \\
\hline
\end{tabular}


Table 2.15. Continued

\begin{tabular}{|c|c|c|c|}
\hline \multirow[b]{2}{*}{ Species } & \multicolumn{3}{|c|}{ Sampling Station } \\
\hline & SI & s3 & S4 \\
\hline $\begin{array}{l}\text { Insecta (continued) } \\
\text { Ephemeroptera } \\
\text { Baetidae } \\
\text { Baetis sp. } \\
\text { Caenidae } \\
\text { Caenis simulans? }\end{array}$ & & + & + \\
\hline $\begin{array}{l}\text { Lepidoptera } \\
\text { Pyralidae } \\
\qquad \text { Nymphula sp. }\end{array}$ & + & & \\
\hline $\begin{array}{l}\text { Trichoptera } \\
\text { Hydropsychidae } \\
\text { Cheumetopsyche pettiti } \\
\text { Hydroptilidae } \\
\text { Hydroptila ajax }\end{array}$ & + & + & $\begin{array}{l}+ \\
+\end{array}$ \\
\hline $\begin{array}{l}\text { Gastropoda } \\
\text { Pulmonata } \\
\text { Physidae } \\
\text { Physa integra } \\
\text { Planorbidae } \\
\text { Gyraulus parvus }\end{array}$ & & + & \\
\hline
\end{tabular}

Table 2.16. Fish in ANL Aquatic Habitats

\begin{tabular}{ll}
\hline \multicolumn{1}{c}{ Common Name } & Scientific Name \\
\hline Black bullhead & $\frac{\text { Ictalurus melas }}{\text { Lepomis machrochirus }}$ \\
Bluegill & $\frac{\text { Semotilus atromaculatus }}{\text { Cotemigonus crysoleucas }}$ \\
Golden shiner & $\frac{\text { Carassius auratus }}{\text { Lepomis cyanellus }}$ \\
Goldfish & Micropterus salmoides \\
Green sunfish & Couesius plumbeus \\
Largemouth bass & Lepomis humilis \\
Northern creek chub & \\
Orange-spotted sunfish &
\end{tabular}




\subsubsection{Endangered and Threatened Species}

An opinion rendered by the U.S. Fish and Wildlife Service indicated that the only federally listed endangered or threatened vertebrate species likely to be present in the vicinity of the ANL site is the Indiana bat (Myotis sodalis) (Bumgarner 1980). However, ecological surveys have not recorded this species on the ANL site (Argonne Natl. Lab. 1979a). In addition, a September 1980 update of the "Red Book" for the North Central Region (U.S. Fish Wildl. Serv. 1980) lists the federally endangered bald eagle (Haliaeetus leucocephalus) as wintering in nearby Will County. The April 1979 additions to the Great Lakes Region "Red Book" (U.S. Fish. Wildl. Serv. 1979) indicate that both American and arctic subspecies of the peregrine falcon (Falco peregrinus anatum and $F$. p. tundrius) and Kirtland's warbler (Dendroica kirtlandii) migrate through northeastern Illinois and thus might occasionally be found on or near the ANL site. All three of these bird taxa are on the federal endangered species list.

At least two plant species proposed for federal endangered/threatened designation are known to occur in counties near the ANI site and therefore might be present here. These are Thismia americana, found on wet prairies in Cook County (U.S. Fish Wildl. Serv. 1979); and Plantago cordata (heart-leaf plantain), a plant of wet woodlands recorded in Will County (Jones 1976-personal communication).

In addition to the federal designations, the Natural Land Institute (1981) has published an endangered/threatened species list for Illinois. Distribution records for these species suggest that several might occur on or near the ANL site. These are the spotted turtle (Clemmys guttata), recorded from Cook and Will counties; the bobcat (Lynx rufus), known from Cook and several other northeastern Illinois counties; the red-shouldered hawk (Buteo lineatus), documented in both Cook and Will counties; and the upland sandpiper (Bartramia longicauda), likewise found in Cook and Will counties. Eight other bird species listed as being endangered/threatened in Illinois have been recorded in either Cook or Will counties, but not both. Because of the mobility of birds, these might also be found in the ANL vicinity.

Fifteen plant species listed as endangered (Table 2.17) and 11 plant species listed as threatened (Table 2.18) in Illinois occur in at least one county adjacent to the ANL site and also occur (or probably occur) in at least one other adjacent county. These plant taxa are likely candidates for occurrence on or very near ANL. A number of additional plants have been documented in only one adjacent county, but may still be found at ANL.

\subsubsection{Background Radiation Characteristics}

At any point on the earth's surface, a natural background radiation flux is constantly present. This flux arises from cosmic rays, from naturally radioactive substances in the ground, and from dusts and gases in the atmosphere originating in the decay chains of natural materials and in the cosmic ray activation of airborne substances.

To the natural background is added radiation from coal combustion and from radon and radioactive dusts freed in uranium and other mining. Also present are transuranic elements and fission products from bomb tests and, to 
Table 2.17. Endangered Plant Species in Illinois That Occur (or Probably Occur) in More Than One County Adjacent to Argonne National Laboratory

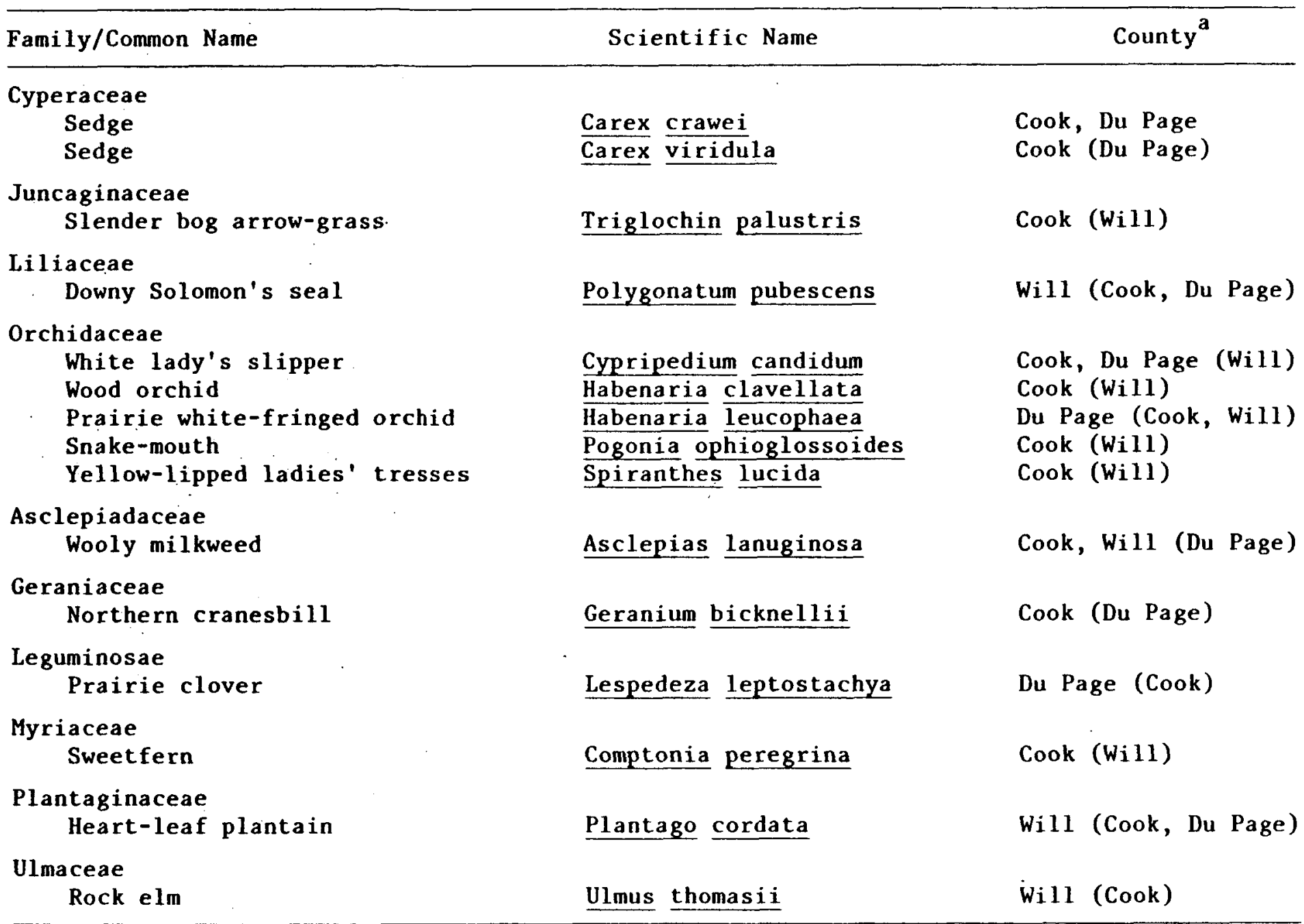

${ }^{a}$ Counties in parentheses are thought to have one or more populations of the species indicated, or once had documented populations that may or may not still be present there.

Source: Natural Land Institute. (1981). 
Table 2.18. Threatened Plant Species in Illinois That Occur (or Probably Occur) in More than One County Adjacent to Argonne National Laboratory

\begin{tabular}{|c|c|c|}
\hline Family/Common Name & Scientific Name & County ${ }^{a}$ \\
\hline $\begin{array}{l}\text { Cyperaceae } \\
\text { Spike rush }\end{array}$ & Eleocharis rostellata & Cook (Will) \\
\hline $\begin{array}{l}\text { Liliaceae } \\
\text { False asphodel }\end{array}$ & Tofieldia glutinosa & Cook (Will) \\
\hline $\begin{array}{l}\text { Orchidaceae } \\
\text { Grass pink orchid } \\
\text { Spotted coral-root orchid } \\
\text { Tubercled orchid }\end{array}$ & $\begin{array}{l}\text { Calopogon tuberosus } \\
\text { Corallorhiza maculata } \\
\text { Habenaria flava }\end{array}$ & $\begin{array}{l}\text { Cook, Will (Du Page) } \\
\text { Cook, Will, Du Page } \\
\text { Cook, Will }\end{array}$ \\
\hline $\begin{array}{l}\text { Araliaceae } \\
\text { Ginseng }\end{array}$ & Panax quinquefolius & Cook, Will, Du Page \\
\hline $\begin{array}{l}\text { Caryophyllaceae } \\
\text { Slender sandwort }\end{array}$ & Arenaria patula & Du Page, Will (Cook) \\
\hline $\begin{array}{l}\text { Droseraceae } \\
\quad \text { Narrow-leaved sundew }\end{array}$ & Drosera intermedia & Cook, Will \\
\hline $\begin{array}{l}\text { Ranunculaceae } \\
\text { Golden seal }\end{array}$ & Hydrastis canadensis & Du Page, Will (Cook) \\
\hline $\begin{array}{l}\text { Rosaceae } \\
\quad \text { Queen-of-the-prairie }\end{array}$ & Filipendula rubra & Cook (Du Page) \\
\hline $\begin{array}{l}\text { Scrophulariaceae } \\
\text { Marsh speedwell }\end{array}$ & Veronica scutellata & Cook, Du Page (Will) \\
\hline
\end{tabular}

${ }^{a}$ Counties in parentheses are thought to have one or more populations of the species indicated, or once had documented populations that may or may not still be present.

Source: Natural Land Institute (1981). 
a small degree, from commercial nuclear reactors. In addition, the average person is exposed to medical radiation for diagnosis and therapy.

In order to evaluate the ANL contribution to ambient radioactivity, it is necessary to determine the natural and artificial background radiation levels. General data on radiation levels are available from a number of national and local sources, and detailed local information is available from an extensive monitoring program conducted by the OHS Environmental Monitoring Group. This latter work is accomplished by measuring the concentrations of radioactive materials in naturally occurring materials and by measuring the external penetrating radiation dose. Samples of air particulates, water, soil, plants, foodstuffs, precipitation, and material from the beds of lakes and streams are collected. Specific radiochemical separation procedures are used to analyze these samples and measurements are made with sensitive low-background counting equipment. The monitoring program has been in operation since 1948, and the results have been published in annual reports (1973-1974 reports: Sedlet et al. 1974-1975; 1975-1980 reports: Golchert et al. 1976-1981). This large reservoir of available information provides an adequate baseline for measuring current and future plant impacts.

The general data sources show that the ANL area is close to the national average radiation level with values of 45 and $65 \mathrm{mrem} / \mathrm{yr}$ for cosmic and terrestrial external radiation, respectively, and $25 \mathrm{mrem} / \mathrm{yr}$ for internal (ingested and inhaled) radiation (U.S. Environ. Prot. Agency 1977). The average medical dose (to bone marrow) is about $103 \mathrm{mrem} / \mathrm{yr}$, for a total average of $238 \mathrm{mrem} / \mathrm{yr}$.

The ANL monitoring program is described in Section 2.3.2; a number of results are also given there. In general, variations in background radiation are due almost entirely to changes in fallout from weapons tests; the level in any case is, at most, $2 \%$ of permissible concentrations.

\subsection{EFFLUENT AND ENVIRONMENTAL MONITORING PROGRAMS}

Nonradiological monitoring is conducted by the Industrial Hygiene Group of OHS; radiological monitoring is conducted by the Environmental Monitoring Group of OHS.

\subsubsection{Nonradioactive}

\subsubsection{Air}

OHS samples ambient air on a continuous basis for particulates, sulfur dioxide, and lead. The particulate sampling program has been in progress for several years. Its purpose is to establish preoperational and operational levels of particulate matter related to conversion of ANL boilers to coal burning. Lead monitoring has been carried on for some time. The purpose of this program is to obtain information on the distribution of lead aerosol in air for use in hydrological studies, since a primary source of lead in water is lead scavenged from air by precipitation. 


\subsubsection{Liquids}

A very extensive monitoring program of all ANL liquid effluents has been carried on for some years. Additionally, Sawmill Creek, the Des Plaines River, and the domestic wells have been sampled to determine the impact of effluents on these waters. The constituents sampled are listed in Table 2.19. The sampling methods, analytical methods, and results (except for the domestic wells) are described in the annual monitoring reports, the most recent being for 1980 (Golchert et al. 1981). A summary of liquid plant effluents is contained in Section 3.1.2.1.2; the effects on Sawmill Creek of liquid effluents are given in Section 3.1.3.2.2.

\section{3 .1 .3 Solids}

In the past, soil samples have been analyzed for selected elements (Sedlet and Duffy 1972). Soil and bottom samples are routinely analyzed only when the hydrological analyses indicate that they would be necessary.

\subsubsection{Radioactive}

\subsubsection{Air}

A continuous monitoring program is conducted for air particulates, tritiated water vapor, and noble gases. Samples are collected at the site perimeter and offsite for comparison. Continuous offsite monitoring is necessary because many of the materials being used or produced by the Laboratory are also naturally occurring or products of fallout from atmospheric nuclear tests.

The radioactivity of particulate matter is determined by collecting and analyzing air-filter samples. There are eight sampling locations at the site perimeter and five offsite. These filters are analyzed for alpha, beta, and gamma-ray radioactivity. Air-filter samples for radiochemical analysis are collected at two locations at the site perimeter and at one offsite location. Monthly composite samples are ignited, the residue leached with acids, and the elements of interest chemically separated. Each monthly set of air filters is analyzed for radiostrontium, thorium, uranium, and plutonium. Tritiated water vapor in air is collected by adsorption on a dessicant and measured by counting the desorbed water in a liquid scintillation counter. Argon-4l and other noble gases are collected by filling an evacuated "Marinelli-type" container with air and measured by gamma-ray spectrometry. Precipitation samples are also collected and analyzed.

\subsubsection{Liquids}

ANL-treated wastewater is discharged into Sawmill Creek, which is sampled above and below the site to evaluate the effect of ANL operations on its radioactive content. Samples are analyzed for nonvolatile alpha and beta activities along with the radionuclides of hydrogen, strontium, iodine, barium, uranium, neptunium, plutonium, americium, curium, and californium. Sawmill Creek flows into the Des Plaines River, which in turn flows into the Illinois River. Measurements of these radionuclides are also periodically made on samples from the Des Plaines River. Results of recent monitoring are presented in Section 3.1.2.2. 
Table 2.19. Chemical Constituents in ANL Effluents and Sampled Water

\begin{tabular}{|c|c|c|c|c|}
\hline \multirow[b]{2}{*}{ Constituent } & \multicolumn{4}{|c|}{ Source of Sample } \\
\hline & $\begin{array}{c}\text { ANL Waste } \\
\text { Treatment } \\
\text { Plant Effluent }\end{array}$ & $\begin{array}{l}\text { Cooling Tower } \\
\text { Effluent }\end{array}$ & $\begin{array}{l}\text { Sawmill } \\
\text { Creek }\end{array}$ & $\begin{array}{c}\text { Des Plaines } \\
\text { River }\end{array}$ \\
\hline Ammonia-nitrogen & $\mathrm{X}$ & - & $x$ & - \\
\hline Barium & $\mathrm{X}$ & - & $\mathrm{X}$ & - \\
\hline Beryllium & $\mathrm{X}$ & - & $x$ & - \\
\hline BOD & $\mathrm{X}$ & - & - & - \\
\hline Cadmium & $\mathrm{X}$ & - & $\mathrm{X}$ & - \\
\hline Chromium (III) & $\mathrm{X}$ & $\mathrm{X}$ & $\mathrm{X}$ & - \\
\hline Chromium (VI) & $\mathrm{x}$ & $\mathrm{x}$ & $\mathrm{x}$ & $\mathrm{x}$ \\
\hline Copper & $\mathrm{x}$ & - & $\mathrm{x}$ & - \\
\hline Cyanide & - & - & $\mathrm{X}$ & - \\
\hline Fluoride & $\mathrm{X}$ & - & $\mathrm{X}$ & - \\
\hline Iron & $\mathrm{X}$ & - & $\mathrm{X}$ & $\mathrm{x}$ \\
\hline Lead & $\mathrm{X}$ & - & $\mathrm{x}$ & - \\
\hline Manganese & $\mathrm{X}$ & - & $\mathrm{X}$ & $\mathrm{X}$ \\
\hline Mercury & $\mathrm{x}$ & - & $\mathrm{x}$ & $\mathrm{x}$ \\
\hline Nickel & $\mathrm{X}$ & - & $\mathrm{X}$ & - \\
\hline Dissolved oxygen & - & - & $\mathrm{X}$ & - \\
\hline $\mathrm{pH}$ & $\mathrm{x}$ & - & $x$ & - \\
\hline Silver & $\mathrm{x}$ & $\mathrm{x}$ & $\mathrm{x}$ & - \\
\hline Dissolved solids & - & - & $\mathrm{X}$ & - \\
\hline Suspended solids & $\mathrm{x}$ & - & - & - \\
\hline Zinc & $\mathrm{x}$ & $\mathbf{X}$ & $\mathrm{x}$ & $\mathrm{X}$ \\
\hline
\end{tabular}

a Those constituents sampled at the indicated sources are identified by the symbol $X$. 


\subsubsection{Solids}

The OHS Environmental Monitoring Program conducts sampling of soil, grass, and bottom sediment at the site perimeter and offsite, and of foodstuffs offsite. Samples are analyzed for gamma-ray emitting nuclides by gamma-ray spectrometry, and for thorium, uranium, and plutonium by chemical means. Milk is collected from a local dairy farm and analyzed for hydrogen-3, strontium-89 and -90 , iodine-131, cesium-137, and barium-140. Measurements of penetrating radiation using thermoluminescent dosimeters are conducted on and of $f$ the site. The most recent results of all of the above measurements are given in Golchert et al. (1981) and are discussed in Section 3.1.2.2.

REFERENCES (Section 2)

Argonne National Laboratory. 1978. "Terrestrial and Aquatic Information Packages." Argonne, IL. December 15, 1978.

Argonne National Laboratory. 1979a. "Draft Environmental Impact Statement, Argonne National Laboratory, Argonne, Illinois." Unpublished review copy (March 1979).

Argonne National Laboratory. 1979b. "Environmental Analys is of a Formerly Utilized MED/AEC Site. Site $A$ and Plot $M$, Palos Forest Preserve, Palos Park, Illinois." ANL/ES-79. Prepared for the U.S. Department of Energy, Office of Remedial Action Programs. April 1979.

Argonne National Laboratory. 1980a. "Environmental Assessment Related to the Conversions of Boilers No. 1 and No. 5 at Argonne National Laboratory." DOE/EA-0126; ANL/ES-107. Prepared by the Division of Environmental Impact Studies for the U.S. Department of Energy. December $1980.108 \mathrm{pp}$.

Argonne National Laboratory. 1980b. "Institutional Plan FY 1981-FY 1986." August 1980.

Argonne National Laboratory. 1982. Implementation of the National Environmental Policy Act. Health and Safety Manual, Chapter III-12.

Argonne Universities Association. 1982. "Report." 100 pp.

Bumgarner, D.H. 1980. Letter (U.S. Fish and Wildlife Service) to R.H. Bauer (DOE/CORO).

Curtis, S.A., and A. Berlin. 1980. "A Study of the Cultural Resources at the Argonne National Laboratory." Division of Environmental Impact Studies, Argonne National Laboratory. Draft report.

Denmark, W. 1974. "The Climate of Illinois." In "Climate of the States, Volume 1." U.S. Department of Commerce, National Oceanic and Atmospheric Administration. 
Downer, A.S. 1980. Letter (Chief Staff Archaeologist, Illinois Department of Conservation, Springfield, IL) dated August 28, 1980, to S.A. Curtis (Argonne National Laboratory, Argonne, IL):

Golchert, N.W., T.L. Duffy, and J. Sedlet. 1976. "Environmental Monitoring at Argonne National Laboratory, Annual Report for 1975." Argonne National Laboratory Report ANL-76-29. March 1976.

Golchert, N.W., T.L. Duffy, and J. Sedlet. 1977. "Environmental Monitoring at Argonne National Laboratory, Annual Report for 1976." Argonne National Laboratory Report ANL-77-13. March 1977.

Golchert, N.W., T.L. Duffy, and J. Sedlet. 1978. "Environmental Monitoring at Argonne National Laboratory, Annual Report for 1977." Argonne National Laboratory Report ANL-78-26. March 1978.

Golchert, N.W., T.L. Duffy, and J. Sedlet. 1979. "Environmental Monitoring at Argonne National Laboratory, Annual Report for 1978." Argonne National Laboratory Report ANL-79-24. March 1979.

Golchert, N.W., T.L. Duffy, and J. Sedlet. 1980. "Environmental Monitoring at Argonne National Laboratory, Annual Report for 1979." Argonne National Laboratory Report ANL-80-29. March 1980.

Golchert, N.W., T.L. Duffy, and J. Sedlet. 1981. "Environmental Monitoring at Argonne National Laboratory, Annual Report for 1980." Argonne National Laboratory Report ANL-81-23. March 1981.

M.P. White Associates. 1968. "Seismic Analysis of Selected CP-5 Reactor Systems and Components." Prepared for Argonne National Laboratory, Argonne, IL. July 15, 1968.

Messenger, A.S., W.R. Suter, and J.A. Wagner. 1969. "Ecological Survey of Argonne National Laboratory." Argonne National Laboratory Report ANL-7559.

Moses, H., and M.A. Bogner. 1967. "Fifteen-Year Climatological Summery, January 1, 1950 - December 31, 1964." Argonne National Laboratory Report ANL-7084. September 1967.

National Oceanic and Atmospheric Administration. 1970. "Tornado." NOAA/ PI 70007 .

National Oceanic and Atmospheric Administration. 1973. "Earthquake History of the United States." Publ. 41-1. Rev. ed. (through 1970). U.S. Department of Commerce.

National Oceanic and Atmospheric Administration. 1980. "1979 Annual Summary of Local Climatological Data, Chicago, Illinois, Midway Airport." Environmental Data Service.

Sasman, R.T., P. Kraatz, and R.A. Landon. 1966. "Water-Level Decline and Pumpage in Deep Wells in Northeastern Illinois, 1961-1966." Ill. State Geol. Surv. Circ. 94. 
Sedlet, J., and T.L. Duffy. 1972. "A Study of Radioactive and Toxic Elements on the ANL Peripheral Land." Argonne National Laboratory unpublished report. January 14, 1972.

Sedlet, J., N.W. Golchert, and T.L. Duffy. 1974. "Environmental Monitoring at Argonne National Laboratory, Annual Report for 1973." Argonne National Laboratory Report ANL-8078. March 1974.

Sedlet, J., N.W. Golchert, and T.L. Duffy. 1975. "Environmental Monitoring at Argonne National Laboratory, Annual Report for 1974." Argonne National Laboratory Report ANL-75-18. March 1975.

U.S. Atomic Energy Commission. 1974a. "Design Basis Tornado for Nuclear Power Plants." Regulatory Guide 1.76. April 1974.

U.S. Atomic Energy Commission. 1974b. "Technical Basis for Interim Regional Tornado Criteria." WASH-1300. Office of Regulation. May 1974.

U.S. Bureau of the Census. 1977. "County Business Patterns 1975, Illinois." CBP-75-15. U.S. Department of Commerce. September 1977.

U.S. Environmental Protection Agency. 1977. "Radiological Quality of the Environment in the United States, 1977." EPA 520/1-77-009. September 1977.

U.S. Environmental Protection Agency. 1980. "Designation of Areas for Air Quality Planning Purposes, 40 CFR Part 81." Fed. Regist. 45:6786 (January 30).

Willman, H.B. 1971. "Summary of the Geology of the Chicago Area." I1l. State Geol. Surv. Circ. 460. 


\section{ENVIRONMENTAL IMPACTS}

This section discusses the environmental impacts resulting from operation of ANL. Included are detailed evaluations of the impacts associated with both routine operations and abnormal, i.e, accident, conditions. The latter category considers process-initiated accidents as well as accidents induced by natural phenomena, e.g., tornadoes.

\subsection{IMPACTS DUE TO ROUTINE OPERATIONS}

\section{1 .1 Introduction}

In the course of normal operations at ANL, a great many different kinds of wastes are produced. These substances range from ordinary types of waste, such as sanitary sewage and combustion gases from the central boiler plant, to small amounts of potentially toxic, carcinogenic, radioactive, or pathogenic materials resulting from the many nuclear, chemical, and biological research programs of the Laboratory.

Each type of waste is controlled and treated as necessary to minimize damage to the environment. For many operations, the quantities of harmful materials are so small that only a minimum degree of control is necessary for their containment. For other operations, controls and treatment systems are installed that reduce routine discharges to levels that in most cases are undetectable beyond the immediate discharge point and, with a few minor and sporadic exceptions, meet all applicable release criteria.

For any potentially harmful waste, detailed waste handling procedures are prepared and continually reviewed by the Waste Operations Manager (Argonne Natl. Lab. 1977b). All significant waste operations are handled, supervised, and/or monitored by special groups within Plant Facilities and Services (PFS), Occupational Health and Safety (OHS), and Special Materials (SPM). Individuals working with hazardous materials are carefully trained in the methods and responsibilities of handling such materials.

In the following sections the production, control, and disposition of routine wastes are described. Major single or combined effluent sources are individually described, with general descriptions being given of the smaller waste sources. The impacts of the releases on the environment are then discussed. 


\subsubsection{Description and Environmental Effects of Routine Releases}

\subsubsection{Nonradioactive Releases}

\subsection{Atmospheric Releases}

Boiler Plant

The largest single source of nonradioactive atmospheric discharges is the central boiler plant. The plant normally burns natural gas in four of the five boilers, but in case of shortages, distillate or residual fuel oil can also be used. One of the five boilers has recently (1981) been modified to burn high-sulfur coal. With the conversion of Boiler No. 5, burning 45,000 metric tons of high-sulfur coal each year will replace the consumption of about $3.5 \times 10^{7} \mathrm{~m}^{3}$ of natural gas and up to $2900 \mathrm{~m}^{3}$ of fuel oil with slight attendant increases in emission of particulates and sulfur dioxide $\left(\mathrm{SO}_{2}\right)$. The conversion included installation of components for flue-gas cleaning, specifically of a scrubber for $80 \%$ sulfur dioxide removal and a baghouse for $99 \%$ particulate removal (Argonne Natl. Lab. 1980).

The combined emissions resulting from operation of all five boilers are within guidelines specified in the Clean Air Act Amendments of 1977, and no violations of National Ambient Air Quality Standards exist. Particulate and sulfur dioxide emissions also comply with all federal and state standards and do not appreciably add to local ambient levels offsite (Argonne Natl. Lab 1980). The boiler plant is not subject to NOx standards because of its small size. As previously indicated, ANL is located in an area that is currently classified "nonattainment" for secondary total-suspended-particulates (TSP) standards.

Air quality modeling studies were undertaken by ANL as part of an Environmental Assessment related to the conversion of Boilers Nos. 1 and 5 to coal burning (Argonne Natl. Lab. 1980b). Since only Boiler No. 5 was ultimately converted, the modeling studies provide a very conservative indication of the impact of current boiler plant operation on local air quality.

The CRSTER dipersion model (U.S. Environ. Prot. Agency 1977) was used to estimate the long- and short-term air quality impacts. The model was designed to simulate atmospheric-dispersion processes for calculating ambient concentration levels of various atmospheric contaminants emitted from a single point source. The addition of these predicted concentrations to ambient background levels determined from air-monitoring data determines compliance with air quality standards. The model requires a specific set of input data and yields output data consisting of pollutant concentrations for specific averaging times and receptor locations. It requires information about the source, site, and meteorology. Source factors relate to stack characteristics such as physical height, gas temperature, emissions characteristics, and site factors dealing with the effect of the terrain. Meteorological requirements are dispersion properties of the atmosphere at any particular time in terms of joint occurrence of specific conditions of atmospheric stability, mixing height, and wind speed and direction.

The maximum incremental increase in annual-mean, ground-level concentration for TSP is predicted by the model as $0.29 \mu \mathrm{g} / \mathrm{m}^{3}$ at about $1 \mathrm{~km}$ northeast 
$\left(40^{\circ}\right)$ of the plant. The second-highest 24-hour TSP average is predicted as $3.18 \mathrm{\mu g} / \mathrm{m}^{3}$ at about $2 \mathrm{~km}$ southwest $\left(220^{\circ}\right)$ of the plant. These predicted incremental increases in ground-level TSP concentrations are far lower than normal ambient variations and represent an insignificant impact on air quality of the surrounding area.

For sulfur dioxide concentrations from the boilers, the highest groundlevel contributions are predicted to occur between 1 and $2 \mathrm{~km}$ from the plant. The predicted incremental increase in maximum annual-mean concentration is $4.50 \mu \mathrm{g} / \mathrm{m}^{3}$, the second-highest 24 -hour average is $53.1 \mu \mathrm{g} / \mathrm{m}^{3}$, and the secondhighest 3 -hour average is $157.1 \mu \mathrm{g} / \mathrm{m}^{3}$. All values are well below their respective Prevention of Significant Deterioration (PSD) increments of $20 \mu g / \mathrm{m}^{3}$, $91 \mu \mathrm{g} / \mathrm{m}^{3}$, and $512 \mu \mathrm{g} / \mathrm{m}^{3}$. These emissions, along with other minor products of sulfur combustion, will create some occasional odor within the forest preserve, but these rare occurrences are not expected to impair the use of the resource in any way.

The predicted maximum, annual-mean, ground-level NOx concentration is $62.5 \mu \mathrm{g} / \mathrm{m}^{3}$, and occurs $1 \mathrm{~km}$ from the stack. Historic background levels near ANL are estimated at $40-50 \mu \mathrm{g} / \mathrm{m}^{3}$. At distances greather than $5 \mathrm{~km}$, the contributions from the boilers fall below a maximum of $10.4 \mu \mathrm{g} / \mathrm{m}^{3}$ and are indistinguishable from normal ambient variations.

\section{Carcinogens}

BIM has several research programs involving the use of recognized or suspected carcinogens. These materials are generally present in quantities of a few grams or less and are handled in HEPA-filtered hoods. Most of these substances are nonvolatile and would be trapped in a filter; however, a few volatile substances such as benzene could reach the atmosphere. The amounts released are small, and in view of the fact that ANL is within several kilometers of two large oil refineries and several more tank storage areas where benzene and many other organic compounds are commonly released, it is highly unlikely that any ANL contribution could be detected.

\section{Miscellaneous}

A number of other potential sources of dust or volatile materials exist in many of the ANL facilities. Hazardous materials are generally handled in HEPA-filtered hoods or gloveboxes; the volumes of volatile organic solvents released are not large enough to be detectable above background. In those buildings where large quantities of sodium are burned for disposal, highefficiency scrubbers are used to clean the exhaust air before passing the system exhaust through filters. In none of the above cases are routine releases large enough to have more than a very localized effect.

The Argonne cooling towers emit relatively large amounts of pure water vapor and small amounts of spray (drift) containing whatever chemicals or dissolved materials are present in the circulating water. In cold or humid weather, a visible steam plume will develop but will dissipate in a distance of about $1 \mathrm{~km}$. or less; in very cold weather ice may form on nearby vegetation or buildings. Slight damage to nearby vegetation by the ice is possible. The spray from the towers will largely evaporate; however, small amounts may fall to the ground immediately downwind of the towers. It is conceivable that 
damage to vegetation from the contained salts may occur in the immediate vicinity of the towers; however, no damage is presently obvious. The small size and low height of the towers preclude any offsite damage.

\subsection{Liquid Releases}

\section{Boiler Plant}

Three liquid effluents related to operation of the boiler plant (coal pile runoff, component cooling water, and boiler blowdown) are released to the water treatment lime pond near the boiler plant and subsequently enter Sawmill Creek.

The component cooling water is taken from the Sanitary and Ship Canal and used after lime-alum flocculation/settling treatment. The water is originally of a very low quality and is improved somewhat by the treatment. The annual volume is $4.9 \times 10^{4} \mathrm{~m}^{3} / \mathrm{yr}$ or $95 \mathrm{~L} / \mathrm{min}$. Small quantities of corrosion products (iron) enter the water during passage; however, the volume of water is so small and the quality of Sawmill Creek water is so poor that no detectable effects will occur from discharge.

The boiler blowdown is about $3.4 \times 10^{4} \mathrm{~m}^{3} / \mathrm{yr}$ or $64 \mathrm{~L} / \mathrm{min}$. The major impurities are $1000 \mathrm{mg} / \mathrm{L}$ of dissolved solids consisting primarily of sulfate, chloride, sodium, and calcium ions. These ions are common components of natural waters, and the small quantities added are quickly diluted to harmless levels.

A storage pile of about $20,000 \mathrm{t}$ of coal occupies an area of about 0.6 ha near the plant. The average annual precipitation in Illinois is about $870 \mathrm{~mm}$, so the annual coal-pile runoff will be about $5000 \mathrm{~m}^{3} / \mathrm{yr}$. The composition of the runoff will vary greatly depending on the type and degree of cleaning of the coal, the age of the coal, and the structure of the coal pile. of concern are the high levels of dissolved and suspended solids, the low $\mathrm{pH}$ value, and the high levels of iron and sulfate, particularly in aged coals. Among the components of organic carbon are a number of polynuclear aromatic hydrocarbons, which are potential carcinogens. In view of the low average flows and the treatment, no detectable effects on surface water should occur. The pond outlet is currently monitored for suspended solids, total solids, phosphorus, temperature, $\mathrm{pH}$, and flow in accordance with the NPDES permit for ANL under the Clean Water Act of 1977.

It is planned that in the summer of 1982 the treatment-pond effluent will be collected and pumped into an existing sanitary sewer line that discharges. into the site sewage waste treatment facility (Bldg. 570). This facility has an outfall into Sammill Creek. Therefore, a more effective monitoring and control system, utilizing only one discharge point, will be implemented for process effluent from the boiler, water treatment, and waste treatment plants.

\section{Sanitary and Laboratory Waste Treatment Facilities}

The effluents of the sanitary and laboratory waste systems are combined, chlorinated, and released. Approximately $1100 \mathrm{~kg}$ of chlorine are added to the water per year for final disinfection, resulting in an initial treatment level of about $0.5 \mathrm{ppm}$ of free chlorine in the effluent. A 31 -min contact time in 
the chlorine chamber, plus the time for flow through the 1220-m-long discharge pipe, reduce this level considerably before the effluent is discharged to Sawmill Creek.

Concentrations of major and trace constituents in the waste treatment plant combined effluent for 1980 are shown in Tables 3.1 and 3.2 , respectively. Further details are contained in the 1980 annual monitoring report (Golchert et al. 1981). Ammonia-nitrogen exceeded the state standard in some samples, although the annual average was well below. This parameter is no longer covered by the ANL NPDES permit because of a change in the Illinois standards. The five-day $B O D$ and suspended solids concentrations were well below the standards. The sanitary waste treatment plant provides typical pollutant-reduction factors of more than $95 \%$ for BOD and solids. Of the trace elements released, only mercury has exceeded state discharge standards, with all other elements well below. In $1980,85 \%$ of discharge samples contained less than state standard levels.

Table 3.1. Major Constituents in Effluent from ANL Treatment Plant, 1980

\begin{tabular}{|c|c|c|c|c|c|c|c|}
\hline \multirow[b]{2}{*}{ Parameter } & \multirow[b]{2}{*}{ Units } & \multirow{2}{*}{$\begin{array}{l}\text { Results Reported/ } \\
\text { Permit Condition }\end{array}$} & \multicolumn{3}{|c|}{ Concentration } & \multirow{2}{*}{$\begin{array}{c}\text { Number } \\
\text { Exceeding } \\
\text { State } \\
\text { Standards }\end{array}$} & \multirow{2}{*}{$\begin{array}{r}\text { Type of } \\
\text { Sample }\end{array}$} \\
\hline & & & Average & Minimum & Maximum & & \\
\hline Flow & $M G D$ & $\begin{array}{l}\text { Reported } \\
\text { Permit condition }\end{array}$ & $\begin{array}{l}0.75 \\
0.84\end{array}$ & 0.43 & 1.39 & - & $\begin{array}{l}\mathrm{NA}^{\mathrm{b}} \\
\mathrm{NA}\end{array}$ \\
\hline BOD & $\mathrm{mg} / \mathrm{L}$ & $\begin{array}{l}\text { Reported } \\
\text { Permit condition }\end{array}$ & $\begin{array}{l}2.8 \\
10\end{array}$ & 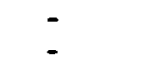 & $\begin{array}{l}8.7 \\
15\end{array}$ & $\begin{array}{l}0 \\
-\end{array}$ & $\begin{array}{l}24 \text {-hour } \\
24 \text {-hour }\end{array}$ \\
\hline $\begin{array}{l}\text { Suspended } \\
\text { solids. }\end{array}$ & $\mathrm{mg} / \mathrm{L}$ & $\begin{array}{l}\text { Reported } \\
\text { Permit condition }\end{array}$ & $\begin{array}{l}4.1 \\
12\end{array}$ & - & $\begin{array}{l}30 \\
18\end{array}$ & $\begin{array}{l}1 \\
-\end{array}$ & $\begin{array}{l}24 \text {-hour } \\
24 \text {-hour }\end{array}$ \\
\hline $\begin{array}{l}\text { Fecal coliform } \\
\text { bacteria }\end{array}$ & $\begin{array}{l}\text { Number/ } \\
100 \mathrm{~mL}\end{array}$ & $\begin{array}{l}\text { Reported } \\
\text { Permit condition }\end{array}$ & $\begin{array}{r}2 \\
200\end{array}$ & - & $\begin{array}{r}22 \\
400\end{array}$ & $\begin{array}{l}0 \\
-\end{array}$ & $\begin{array}{l}\text { Grab } \\
\text { Grab }\end{array}$ \\
\hline $\begin{array}{l}\text { Residual } \\
\quad \text { chlorine }\end{array}$ & $\mathrm{mg} / \mathrm{L}$ & $\begin{array}{l}\text { Reported } \\
\text { Permit condition }\end{array}$ & 0.5 & $\begin{array}{l}0.1 \\
0.2\end{array}$ & $\begin{array}{l}0.7 \\
0.75\end{array}$ & 2 & $\begin{array}{l}\text { Grab } \\
\text { Grab }\end{array}$ \\
\hline \multicolumn{8}{|l|}{ Ammonia-N } \\
\hline Apr - Oct & $\mathbf{m g}_{\mathbf{g}} / \mathrm{L}$ & $\begin{array}{l}\text { Reported } \\
\text { Permit condition }\end{array}$ & $\begin{array}{l}0.8 \\
2.5\end{array}$ & $\overline{-}$ & $\begin{array}{l}2.8 \\
4.0\end{array}$ & $\stackrel{0}{-}$ & $\begin{array}{l}\text { Grab } \\
\text { Grab }\end{array}$ \\
\hline Nov - Mar & $\mathrm{mg} / \mathrm{L}$ & $\begin{array}{l}\text { Reported } \\
\text { Permit condition }\end{array}$ & $\begin{array}{l}3.1 \\
4.0\end{array}$ & - & $\begin{array}{l}8.2 \\
6.0\end{array}$ & $\begin{array}{l}1 \\
-\end{array}$ & $\begin{array}{l}\text { Grab } \\
\text { Grab }\end{array}$ \\
\hline Nitrate $-\mathrm{N}$ & $\mathrm{mg} / \mathrm{L}$ & $\begin{array}{l}\text { Reported } \\
\text { Permit condition }\end{array}$ & 5.3 & $\overline{-}$ & 9.0 & - & $\begin{array}{l}24 \text {-hour } \\
\text { Grab }\end{array}$ \\
\hline Phosphorus-P & $\mathrm{mg} / \mathrm{L}$ & $\begin{array}{l}\text { Reported } \\
\text { Permit condition }\end{array}$ & 1.2 & - & 2.1 & $\begin{array}{l}0 \\
-\end{array}$ & $\begin{array}{l}\text { 24-hour } \\
\text { Grab }\end{array}$ \\
\hline $\mathrm{pH}$ & Units & $\begin{array}{l}\text { Reported } \\
\text { Permit condition }\end{array}$ & $\begin{array}{c}7.1 \\
-\end{array}$ & $\begin{array}{l}6.7 \\
6.5\end{array}$ & $\begin{array}{l}7.7 \\
8.5\end{array}$ & 0 & $\begin{array}{l}\text { 24-hour } \\
\text { Grab }\end{array}$ \\
\hline
\end{tabular}

${ }^{a}$ National Pollution Discharge Elimination System (NPDES) permit.

$\mathrm{b}_{\mathrm{NA}}=$ not applicable.

Source: Golchert et al. (1981). 
Table 3.2. Trace Constituents in Effluent from ANL Treatment Plant, 1980

\begin{tabular}{|c|c|c|c|c|c|c|}
\hline \multirow[b]{2}{*}{ Constituent } & \multirow{2}{*}{$\begin{array}{l}\text { No. of } \\
\text { Samples }\end{array}$} & \multicolumn{3}{|c|}{ Concentration $(\mu \mathrm{g} / \mathrm{L})$} & \multirow{2}{*}{$\begin{array}{c}\text { Percent of } \\
\text { Standard } \\
\text { (Average) }\end{array}$} & \multirow{2}{*}{$\begin{array}{c}\text { Percent } \\
\text { Exceeding } \\
\text { State } \\
\text { Standard }\end{array}$} \\
\hline & & Average & Minimum & Maximum & & \\
\hline Arsenic & 54 & $<5$ & - & $<5$ & $<2.6$ & 0 \\
\hline Barium & 54 & $12 \pm 1$ & 5 & 37 & 0.6 & 0 \\
\hline Beryllium & 12 & $0.06 \pm 0.01$ & 0.03 & 0.08 & - & - \\
\hline Cadmium & 54 & $0.6 \pm 0.1$ & $<0.2$ & 1.5 & 0.43 & 0 \\
\hline Chromium (III) & 54 & $5 \pm 1$ & $<3$ & 33 & 0.5 & 0 \\
\hline Chromium (VI) & 54 & $<5$ & $<5$ & 20 & $<1.2$ & 0 \\
\hline Copper & 54 & $35 \pm 7$ & 18 & 148 & 3.5 & 0 \\
\hline Fluoride & 54 & $269 \pm 13$ & 194 & 430 & 1.8 & 0 \\
\hline Iron & 54 & $258 \pm 18$ & 120 & 422 & 12.9 & 0 \\
\hline Lead & 54 & $3 \pm 0.4$ & $<2$ & 9.6 & 3.1 & 0 \\
\hline Manganese & 54 & $23 \pm 2$ & 9 & 48 & 2.3 & 0 \\
\hline Mercury & 247 & $0.33 \pm 0.04$ & 0.05 & 2.97 & 66.3 & 15 \\
\hline Nickel & 54 & $13 \pm 3$ & 3 & 42 & 1.3 & 0 \\
\hline $\mathrm{pH}$ & 247 & - & 6.3 & 7.8 & - & 0 \\
\hline Selenium & 54 & $<5$ & - & $<5$ & $<0.5$ & 0 \\
\hline Silver & 54 & $3 \pm 0.3$ & 1 & 5 & 2.6 & 0 \\
\hline Zinc & 54 & $141 \pm 20$ & 60 & 362 & 14.0 & 0 \\
\hline
\end{tabular}

Source: Golchert et al. (1981). 
The water quality of Sawmill Creek in relation to the combined sanitary sewer/laboratory sewer treatment plant effluent is shown in Table 3.3 for dissolved oxygen, $\mathrm{pH}$, sulfate, and total dissolved solids, and in Table 3.4 for a number of trace elements. Also shown are state in-stream standards and the fraction of the analyses that exceeded them. The data in Table 3.3 indicate that the ANL discharge has no apparent effect on the gross quality of Sawmill Creek. However, the data in Table 3.4 show that mercury, copper, iron, and silver in creek samples have exceeded state standards. Mercury has not been detected in Sawmill Creek upstream of the ANL sewage outfall; thus the downstream value (Table 3.4 ) is probably due entirely to ANL. The Laboratory has recently begun clearing accumulated sludge from holding tanks in various buildings and at the main treatment plant. It is believed that this will reduce the discharge of mercury.

Elevated iron levels reflect high turbidity conditions with attendant high particulate iron and are not related to Argonne releases. The levels of copper routinely exceed state limits. A previous study of both upstream and downstream levels has shown that water entering above the sampling location contains about $10 \mu \mathrm{g} / \mathrm{L}$ of copper as compared to the annual average of $34 \mu \mathrm{g} / \mathrm{L}$ in the downstream sample. The average level of copper in the ANL effluent, $35 \mu \mathrm{g} / \mathrm{L}$, would produce a level of about $15 \mu \mathrm{g} / \mathrm{L}$ after dilution with creek water. A study has shown that the elevated copper levels in the creek primarily result from entrainment of particulate stream bottom materials in the sampler rather than from ANL effluent contamination (Golchert et al. 1981). During 1980, $2 \%$ of Sawmill Creek samples exceeded the state standard for silver by a small amount. The violation is not believed to be due to the ANL effluent because this discharge did not exceed about $5 \mu \mathrm{g} / \mathrm{L}$ and averaged about $3 \mu \mathrm{g} / \mathrm{L}$.

Fecal coliform upstream of the ANL discharge has often exceeded the state standard for the monthly geometric mean of 200 organisms/100 mI and the individual sample standard of 400 organisms $/ 100 \mathrm{~mL}$. Upstream values are most likely due to the effluent from the Marion Brook municipal sewage treatment plant. In 1980, the ANL sewage effluent did not exceed the monthly standard nor the individual sample standard.

The results of a cursory aquatic biota survey, conducted in 1978 (Argonne Natl. Lab. 1978), combined with the general knowledge of the water quality of Sawmill Creek, enable some conclusions to be drawn concerning the effect of ANL discharges on the biota. The following conclusions should be considered tentative, however, in view of the limited amount of species sampling accomplished for the purposes of this assessment.

Although trends in algal abundance are difficult to assess from single observations, the data indicate that a sampling station located below the ANL treated-effluent outfall was quite different from upstream stations. Observations of Sawnill Creek, at and downstream of the ANL combined-discharge outfall, indicated that effluents discharged from ANL influence algal growth. Upstream of the outfall, green algae (Chlorophyta) and diatoms (Bacillariophyta) dominated; at and downstream of the outfall, blue-green algae (Cyanophyta) dominated. The dominance of blue-green algae extended from the. ANL outfall to the Des Plaines River. Elevated nutrient levels in the ANL effluent could be the cause of blue-green algal dominance below the outfall. 
Table 3.3. Effect of Sanitary Waste on Sawmi11 Creek in 1980

\begin{tabular}{|c|c|c|c|c|c|c|c|}
\hline \multirow[b]{2}{*}{ Constituent } & \multirow[b]{2}{*}{ Location ${ }^{a}$} & \multirow{2}{*}{$\begin{array}{l}\text { No. of } \\
\text { Samples }\end{array}$} & \multicolumn{4}{|c|}{ Concentration $(\mathrm{mg} / \mathrm{L})$} & \multirow{2}{*}{$\begin{array}{c}\text { Percent } \\
\text { Exceeding } \\
\text { State } \\
\text { Standard }\end{array}$} \\
\hline & & & Average & Minimum & Maximum & Standard & \\
\hline \multirow[t]{3}{*}{ Dissolved oxygen } & $7 M(u p)$ & 46 & $10.7 \pm 0.6$ & 6.9 & 14.4 & - & - \\
\hline & $7 M$ (down) & 46 & $10.7 \pm 0.6$ & 7.2 & 14.8 & - & - \\
\hline & & & & $=$ & & & \\
\hline \multirow[t]{2}{*}{ pH } & $7 M(u p)$ & 47 & - & 7.7 & 8.5 & - & - \\
\hline & $7 M$ (down) & 47 & - & 7.6 & 8.4 & - & - \\
\hline \multirow[t]{2}{*}{ Sulfate } & 7M (up) & 12 & $139 \pm 29$ & 76 & 209 & 28 & 0 \\
\hline & $7 M$ (down) & 12 & $140 \pm 29$ & 71 & 211 & 28 & 0 \\
\hline \multirow[t]{2}{*}{$\begin{array}{l}\text { Total dissolved } \\
\text { solids }\end{array}$} & $7 M(u p)$ & 45 & $1100 \pm 106$ & 583 & 1920 & 110 & 55 \\
\hline & $7 M$ (down) & 45 & $1020 \pm 83$ & 577 & 1810 & 101 & 53 \\
\hline
\end{tabular}

${ }^{a}$ Location $7 \mathrm{M}$ (up) is $15 \mathrm{~m}$ upstream from the wastewater outfall. All other samples were collected $60 \mathrm{~m}$ downstream from the outfall.

Source: Golchert et al. (1981). 
Table 3.4. Chemical Constituents in Sawmill Creek, Location $7 \mathrm{M}^{\mathrm{a}}, 1980$

\begin{tabular}{|c|c|c|c|c|c|c|}
\hline \multirow[b]{2}{*}{ Constituent } & \multirow{2}{*}{$\begin{array}{l}\text { No. of } \\
\text { Samples }\end{array}$} & \multicolumn{3}{|c|}{ Concentration $(\mu g / L)$} & \multirow{2}{*}{$\begin{array}{l}\text { Percent of } \\
\text { Standard } \\
\text { (Average) }\end{array}$} & \multirow{2}{*}{$\begin{array}{c}\text { Percent } \\
\text { Exceeding } \\
\text { State } \\
\text { Standard }\end{array}$} \\
\hline & & Average & Minimum & Maximum & & \\
\hline Arsenic & 53 & $<5$ & - & $<5$ & 0.5 & 0 \\
\hline Barium & 53 & $52 \pm 7$ & 21 & 148 & 1.0 & 0 \\
\hline Beryllium & 12 & $0.12 \pm 0.04$ & 0.03 & 0.30 & - & - \\
\hline Cadmium & 53 & $0.9 \pm 0.1$ & 0.1 & 2.1 & 1.8 & 0 \\
\hline Chromium (III) & 53 & $27 \pm 9$ & 3 & 167 & 2.7 & 0 \\
\hline Chromium (VI) & 53 & $<3$ & - & $<3$ & 6 & 0 \\
\hline Copper & 53 & $34 \pm 7$ & 7 & 134 & 172 & 62 \\
\hline Cyanide & 47 & $<20$ & - & $<20$ & $<80$ & 0 \\
\hline Fluoride & 53 & $369 \pm 28$ & 236 & 706 & 26.3 & 0 \\
\hline Iron & 53 & $1840 \pm 500$ & 269 & 9000 & 184 & 57 \\
\hline Lead & 53 & $15 \pm 3$ & 1 & 54 & 15.4 & 0 \\
\hline Manganese & 53 & $194 \pm 36$ & 43 & 684 & 19 & 0 \\
\hline Mercury & 254 & $0.22 \pm 0.04$ & 0.05 & 3.19 & 44 & 8 \\
\hline Nickel & 53 & $14 \pm 3$ & 3 & 57 & 1.4 & 0 \\
\hline $\mathrm{pH}$ & 253 & - & 6.5 & 8.3 & - & 0 \\
\hline Selenium & 53 & $<5$ & - & $<5$ & 0.5 & 0 \\
\hline Silver & 53 & $2.1 \pm 0.3$ & 0.5 & 5.3 & 42.6 & 2 \\
\hline Zinc & 53 & $104 \pm 21$ & 21 & 358 & 10.4 & 0 \\
\hline
\end{tabular}

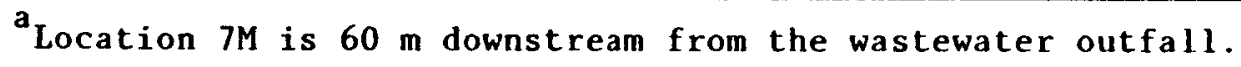

Source: Golchert et al. (1981). 
The overall low diversity index values obtained from the macroinvertebrate survey, in conjunction with the presence of species tolerant of domestic pollution, indicate that the portion of Sawmill Creek flowing through the ANL site can be classified as a semipolluted environment, based on Illinois EPA stream classifications. However, the survey indicates that the water quality conditions due to upstream sewage effluent tend to improve as the stream flows through the site. This is evidenced by the overall higher diversity values downstream of the ANL site boundary and sewer outfall compared with those upstream of ANL. The biotic composition also implies water quality improvements. However, the stream reach within $50 \mathrm{~m}$ downstream of the ANL outfall contained a depauperate macroinvertebrate community; only midges, damselfly larvae, and isopods were observed. Although this area was only sampled qualitatively, it is concluded that ANL discharges may be affecting invertebrate populations in this short stream segment.

About $300 \mathrm{~m}$ below the ANL outfall, Sawmill Creek joins the Des Plaines River. The dilution is sufficiently large (a factor of about 40:1), the water quality of the Des Plaines River so poor, and the amounts of ANL pollutants so small that no detectable effect of any kind on the Des Plaines River could be attributed to ANL operations.

\section{Miscellaneous}

Other nonhazardous, nonradioactive liquid wastes are cooling water discharges from once-through and cooling tower systems, and blowdown from the potable and cooling water treatment plants. In 1977, a total of about $7.1 \times 10^{5} \mathrm{~m}^{3}$ of cooling water were used. In once-through cooling systems, the water is discharged mostly to the storm sewer system, with smaller quantities dumped to the sanitary sewer. There are seven of these discharges that handle the cooling tower effluents as follows: combined 200 area, Bldg. 202, 800 area, canal treatment plant outfall, ZGS cooling, east area cooling, and the water treatment plant and pond overflow. The water quality of the cooling water discharge is obviously improved over that of its source, the Chicago Sanitary and Ship Canal.

Most of the canal water withdrawn is used in 36 cooling towers. These towers have individual circulating flows ranging from 0.02 to $0.75 \mathrm{~m}^{3} / \mathrm{s}$ and discharges (blowdown) of $1.3 \times 10^{-4}$ to $3.1 \times 10^{-3} \mathrm{~m}^{3} / \mathrm{s}$; evaporation of water is from 2.5 to 4 times the blowdown discharge. Most of the towers are operated during the summer only. A number of proprietary antiscalants, rust inhibitors, and biocidal chemicals are used in the towers. These are mostly nontoxic or biodegradable organic compounds; however, zinc phosphate is also used. The amounts used are small, and discharge of the blowdown is to the storm sewer system, which provides substantial dilution before release to aquatic systems.

There are no routine releases of hazardous, nonradioactive liquid wastes. These are handled, as noted in Section 2.1.4.12.3, as if they were radioactive; they are disposed by means suitable for the material and in a manner that is not detrimental to the environment.

\subsection{Solid Wastes}

Solid waste consists mostly of such things as paper, packing materials, wood, building rubble, cafeteria wastes, rags, bottles, tin cans, animal 
bedding, spent sorbant, and boiler plant ash. Computer paper from small users may be present, and the bottles could contain chemical residues. About $12,000 \mathrm{~m}^{3} / \mathrm{yr}$ of debris is usually deposited in the sanitary landfill (see Section 2.1.4.12.4), of which about $15 \%$ is noncompactable items such as wooden crates, tree limbs, and landscaping debris. Approximately $4600 \mathrm{~m}^{3}$ of earth is used for covering. At the current rate of disposal, the landfill capacity is expected to be reached in 1994 .

Runoff water from the sanitary landfill is monitored for $\mathrm{pH}$ and BOD. The values of $\mathrm{pH}$ range from about 7.0 to 7.5 and BOD from 1 to $3 \mathrm{mg} / \mathrm{L}$, both of which are within natural ranges; no effect of the landfill site on the environment is detectable.

\subsection{Miscellaneous}

Various chemicals are used for the control of insects, rodents, and in some areas plant growth. EPA-registered chemicals are used by trained operators in accordance with manufacturers' directions. Biocide use is monitored by the Laboratory's Industrial Hygiene Group. Although biocides can have harmful effects on the ecosystem if used indiscriminately, the amounts used at ANL are small and well-controlled, and no adverse effects have been detected.

Roads are treated for snow and ice removal using approximately $7 \times 10^{5} \mathrm{~kg}$ of rock salt and $1800 \mathrm{~kg}$ of calcium chloride per year. No adverse effects of this salt application have been observed.

\subsubsection{Radioactive Releases}

\subsection{Atmospheric Releases}

Small but measured releases of radioactivity to the atmosphere in 1980 are given in Table 3.5 . These releases are representative of ANL operations in recent years. Only a very few facilities are responsible for these releases; these are discussed separately below.

Although the Chicago Pile-Five $(\mathrm{CP}-5)$ reactor is no longer operating, small amounts of residual tritiated water vapor continue to be emitted from the facility. Measurements of hydrogen-3 in the exhaust stack of the CP-5 reactor indicate about $9 \mathrm{Ci}$ were released in 1980.

The JANUS reactor is operated intermittently and at low power. The only measurable release in 1980 was $0.8 \mathrm{Ci}$ of argon-41.

The Alpha Gamma Hot Cell Facility (AGHCF) is used for the examination of irradiated reactor fuel components. Fission gases and radioactive dusts are usually released on opening sealed fuel elements. A nitrogen atmosphere is maintained in the cells. The nitrogen is exhausted to the atmosphere through HEPA and activated-carbon filters. Approximately $5 \mathrm{Ci}$ of krypton-85 and minute amounts of antimony-125 were released in 1980 .

In the Bldg. 200, Wing $M$ hot cells, experiments involving the electrical heating of irradiated reactor fuels are conducted. The evolved gases are collected for examination; however, minute amounts may escape. The exhaust is 
Table 3.5. Atmospheric Releases of Radioactivity, 1980

\begin{tabular}{|c|c|c|}
\hline Source & Nuclide & $\begin{array}{c}\text { Total Quantity } \\
\text { (Ci) }\end{array}$ \\
\hline$C P-5^{a}$ & Hydrogen-3 & 9 \\
\hline JANUS & Argon-41 & 0.8 \\
\hline \multirow[t]{2}{*}{ AGHCF } & Krypton-85 & 4.9 \\
\hline & Antimony-125 & $2.15 \times 10.5$ \\
\hline \multicolumn{3}{|c|}{ Bldg. 200, Wing $M$} \\
\hline Cell A-1 & Krypton -85 & $1.3 \times 10^{-1}$ \\
\hline \multirow[t]{2}{*}{$\operatorname{Ce} 11 \mathrm{~K}-2$} & Krypton -85 & $8.7 \times 10.2$ \\
\hline & Antimony-125 & $1.28 \times 10^{-4}$ \\
\hline \multirow[t]{5}{*}{ IPNS, Bldg. 391} & Krypton-85 & $7.6 \times 10-5$ \\
\hline & Krypton-79 & $7.1 \times 10-4$ \\
\hline & Argon- 41 & $5.7 \times 10-4$ \\
\hline & Xenon-133 & $1.4 \times 10-5$ \\
\hline & Xenon-135 & $6.5 \times 10^{-5}$ \\
\hline Bldg. 205, E101 & Hydrogen -3 & $6.55 \times 10^{-3}$ \\
\hline
\end{tabular}

passed through HEPA and cryogenic filters before release. In 1980 , the only measurable release was about $2 \times 10^{-1} \mathrm{Ci}$ of krypton-85 and $1.3 \times 10^{-4} \mathrm{Ci}$ of ant imony- 125 .

During 1980, Bldg. 391 (IPNS complex) and B1dg. 205 released very small amounts of radionuclides.

Many individual-facilities handle or release small amounts of radioactivity on an irregular basis. Each such facility is equipped with gaseous waste treatment systems designed to minimize personnel exposure and external releases. A typical building design for handling gaseous and liquid wastes is shown schematically in Figure 3.1. Air flow is controlled by a system of decreasing pressures; net flow is always in the direction of increasing probability of contamination. The ventilation system consists of three main systems in series: the outer access area; the inner laboratory area; and the hood or glovebox line. Air leaving each potentially contaminated area is exhausted 


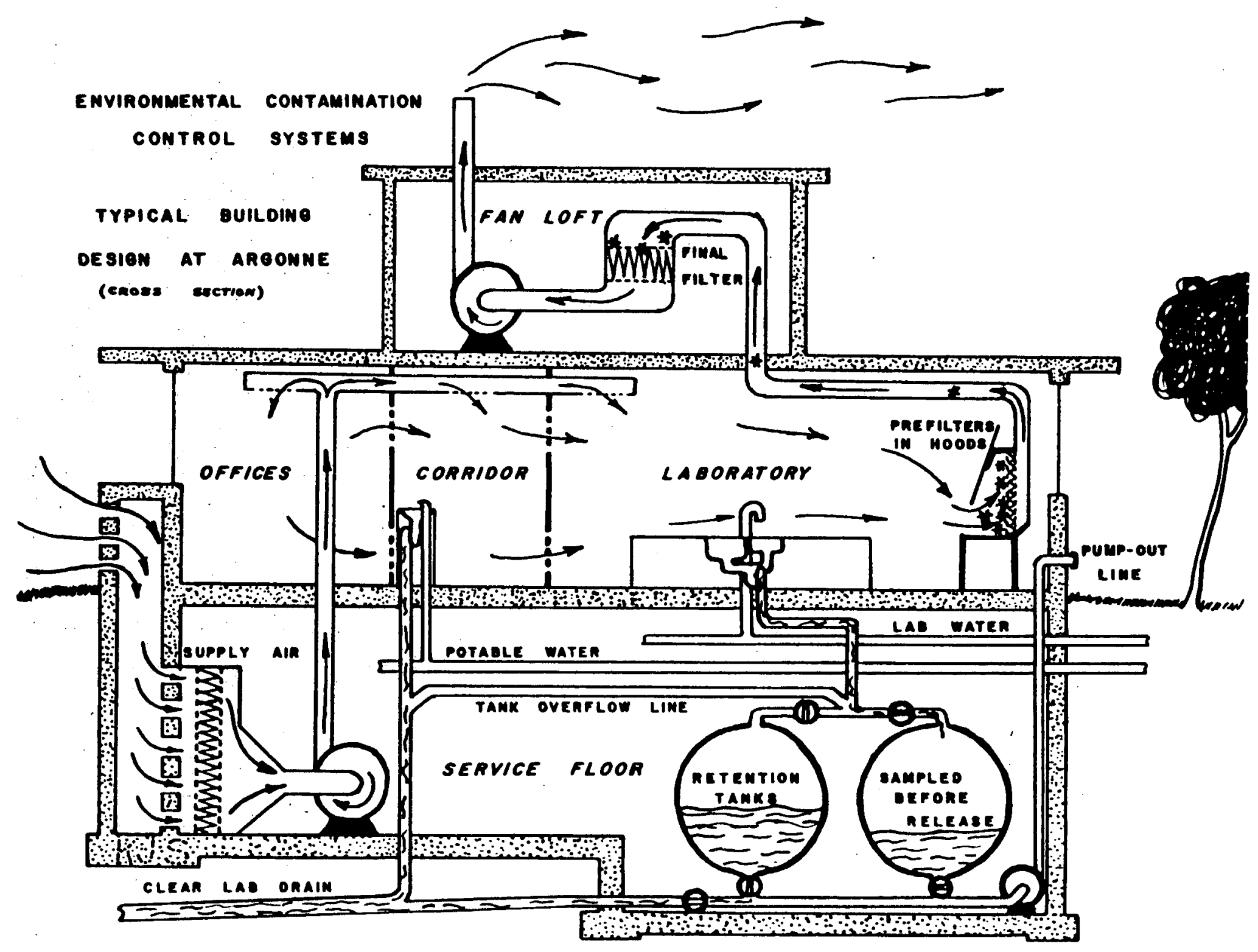

Figure 3.1. Schematic Diagram Showing Typical Laboratory Waste-Handling Processes. 
through one or more HEPA filters before exiting through the exhaust stack. Some exhaust systems are provided with radiation monitors and alarms to allow prompt corrective action in the, event that radiation exceeds predetermined levels. For those laboratory exhausts that are not so monitored and alarmed, operating procedures requiring attention to the radiation-release possibilities are invoked. Critical systems are provided with fire protection and component redundancy for maintenance, repairs, and emergencies.

The HEPA filters are periodically checked by Plant Maintenance (PM) for excessive pressure drop and other defects and by OHS for filter efficiency and high radiation levels. When necessary, the filters are removed and replaced by $\mathrm{PM}$; the removed filters are handled as solid radioactive waste.

The only significant radioactive releases shown in Table 3.5 include the noble gases argon and krypton, and hydrogen-3, which is released primarily as water vapor. The remainder of the releases are extremely minute and nonhazardous amounts of solids that are spread as dusts. The tritium vapor can be apportioned between the air and any condensed water body; however, the maximum effect would occur if the tritium remained in the air, and it is so treated here. The particulate materials can settle to the ground or be rained out.

The dispersed concentrations of the primary radionuclide releases-argon-41, hydrogen-3, and krypton-85--were calculated using the ANL site meteorology data and the XOQDOQ computer program, along with the source terms given in Table 3.5. The XOQDOQ program (described in Appendix B) is a Gaussian plume dispersion model based on Pasquill-Gifford-Turner methods. The equations and constants of NRC Regulatory Guide 1.109 were used to calculate radiation doses (U.S. Nucl. Reg. Comm. 1977). For argon-41 and krypton-85, these were the whole body gamma-radiation dose from a semi-infinite cloud, and for hydrogen- 3 , the adult or teenage dose commitment from hydrogen-3 inhalation.

The following parameters were used in the calculations:

(a) Annual release rates: argon-41, $0.8 \mathrm{Ci}$; hydrogen-3, $9 \mathrm{Ci}$; and krypton-85, $5.1 \mathrm{Ci}$.

(b) Meteorological and wind velocity data.

(c) The usual parameters for stack height, building, wake, plume, momentum, termperature, etc.

The calculations were carried out to $80 \mathrm{~km}$ using the population distribution of 16 segments and 10 distance increments shown in Table 2.3. The dose rate was calculated at the midpoint of each interval and integrated over the entire area to give the annual cumulative dose.

The highest perimeter dose rates are in the north to east sectors. The closest full-time resident, who would receive the largest dose, is located approximately $0.5 \mathrm{~km}$ northeast of the site boundary. The results are summarized in Table 3.6. The maximum 1980 dose to an individual continuously exposed would be $<0.001 \mathrm{mrem} / \mathrm{yr}$. 
Table 3.6. Whole-Body Dose from Airborne Emissions, 1980

\begin{tabular}{|c|c|c|c|c|c|}
\hline \multirow[b]{3}{*}{ Nuclide } & \multirow[b]{3}{*}{ Pathway } & \multicolumn{4}{|c|}{ Dose (mrem) } \\
\hline & & \multicolumn{2}{|c|}{ Maximum Perimeter } & \multicolumn{2}{|c|}{ Maximum Individual } \\
\hline & & Annual & 50-year & Annual & 50-year \\
\hline Hydrogen-3 & Inhalation & 0.0004 & 0.0004 & 0.0002 & 0.0002 \\
\hline Argon -41 & Submersion & 0.0002 & 0.0002 & 0.0001 & 0.0001 \\
\hline Krypton -85 & Submersion & 0.0004 & 0.0004 & 0.0002 & 0.0002 \\
\hline
\end{tabular}

Source: Golchert et al. (1981).

The population data in Table 2.3 were used to calculate the cumulative population dose from hydrogen-3, argon-41, and krypton-85. The results are given in Table 3.7 , together with the natural external radiation dose. The natural radiation dose was that measured at the offsite monitoring locations, and it is assumed that this dose is representative of the entire area within an $80-\mathrm{km}$ radius. The total 1980 population dose within the specified area was $<0.1$ person-rem. The sum of the doses from hydrogen-3, argon-41, and krypton-85 is less than $1 \times 10-5 \%$ of the natural background radiation dose.

Table 3.7. Whole-Body Population Dose Within $80 \mathrm{~km}$

\begin{tabular}{lcc}
\hline & \multicolumn{2}{c}{ Dose (person-rem) } \\
\cline { 2 - 3 } Source & Annual & 50 -year \\
\hline Hydrogen-3 & 0.03 & 0.03 \\
Argon-41 & 0.004 & 0.004 \\
Krypton-85 & 0.02 & 0.02 \\
Natural & $7.15 \times 10^{5}$ & - \\
\hline
\end{tabular}

Source: Golchert et al. (1981).

Although more efficient control technologies for control of particulate radionuclides have resulted in no measurable atmospheric releases of plutonium and uranium at ANL for the past few years, historic annual releases of up to $1.5 \times 10^{-8} \mathrm{Ci}$ of plutonium-239 and $2 \times 10^{-7} \mathrm{Ci}$ of uranium have been measured. The effects of the plutonium-239 released by ANL have been assessed by comparison with data on fallout of plutonium released in bomb tests. For the comparison, all of the plutonium released from ANL is assumed to fall uniformly in a $1.6-\mathrm{km}$-radius circle, and the surface concentration is compared with the 
surface concentration from bomb fallout. The calculated ANL-derived concentration in the circle was $1.6 \times 10^{-15} \mathrm{Ci} / \mathrm{m}^{2}$; the calculated deposition from weapons-test fallout was $1.1 \times 10-11 \mathrm{Ci} / \mathrm{m}^{2}$. The accumulated plutonium, also largely from fallout, was $2.2 \times 10^{-9} \mathrm{Ci} / \mathrm{m}^{2}$. Uranium releases from ANL deposited in a similar manner would constitute about one-millionth of the total surface (5- $\mathrm{cm}$ deep) uranium concentration.

\subsection{Liquid Releases}

No large routine point sources of liquid radioactive waste occur at ANL; however, there are a number of small sporadic sources. The only discharge of liquid radioactive waste to the environment occurs in the combined sanitary waste/laboratory waste outfall in small and carefully regulated amounts after treatment. The treatment systems and guidelines for release are discussed in Section 2.1.4.12.

The treatment of the individual waste sources is as follows. Most radioactive laboratory liquids are generally placed in designated, labeled containers of the proper size, shielded if necessary, and transported by trained crews to the Liquid Waste Processing Facility (Section 2.1.4.12.3) for treatment. However, very small quantities of dilute radioactive wastes may be inadvertently disposed of in laboratory sinks or drains. Liquids from these drains are collected in building retention tanks and monitored; if the activity is acceptably low (Section 2.1.4.12.3), they are discharged to the laboratory sewer system. Liquids that do not meet the discharge criteria are shipped in tank trucks to the waste processing facility. Radionuclides released in liquid wastes in 1980 are listed in Table 3.8. Releases are well under applicable discharge criteria and standards.

The liquid releases shown in Table 3.8 are first diluted about 10 -fold in Sawmill Creek, and after about $300 \mathrm{~m}$ of stream flow are diluted an additional 40-fold by the Des Plaines River. In about $24 \mathrm{~km}$, the Des Plaines River is further diluted 8-fold by the Chicago Sanitary and Ship Canal. No use of the water is made for drinking until it reaches Alton, Illinois, $711 \mathrm{~km}$ downstream, where the Sawmill Creek flow has been diluted by a factor of several thousand. The calculated effects of discharges are therefore small in Sawmill Creek, undetectable in the Des Plaines River, and totally negligible farther downstream (U.S. Geol. Surv. 1973).

Although no major recreational use and no drinking use is made of Sawmill Creek downstream of the ANL outfall, calculations can be made of the hypothetical effects of such use. The dose rates for an adult drinking Sawmill Creek water exclusively are shown in Table 3.9, along with nuclide concentrations and DOE standards for the nuclides (U.S. Energy Res. Dev. Admin. 1977b). About half of the strontium-90 concentration is attributable to ANL operations and the remainder to bomb fallout. These doses are all extremely low and it is unlikely in any case that Sawmill Creek water would be consumed by humans.

\subsection{Solid Wastes}

Solid radioactive wastes are not disposed at the ANL site, but rather are appropriately packaged and shipped for burial at approved disposal sites as described in Section 2.1.4.12.4. Hence, there are no environmental effluents at or near ANL arising from such sources. 
Table 3.8. Releases of Radioactivity to Sawmill Creek, 1980

\begin{tabular}{|c|c|}
\hline Nuclide & $\begin{array}{l}\text { Quantity } \\
(\mathrm{C} i)^{\mathrm{a}}\end{array}$ \\
\hline Strontium $-90^{\mathrm{a}}$ & $0.8 \times 10^{-3}$ \\
\hline Unspecified beta-gamma & $12.4 \times 10^{-3}$ \\
\hline Unspecified alpha ${ }^{a}$ & $1.5 \times 10^{-3}$ \\
\hline Hydrogen-3 & 1.6 \\
\hline Neptunium-237 & $0.7 \times 10^{-4}$ \\
\hline Plutonium-239 & $1.5 \times 10^{-4}$ \\
\hline Americium-241 & $0.6 \times 10^{-4}$ \\
\hline $\begin{array}{r}\text { Curium-244 and/or } \\
\text { Californium- } 249\end{array}$ & $<0.5 \times 10-4$ \\
\hline
\end{tabular}

Table 3.9. Radionuclide Concentrations and Dose Estimates for Sawmill Creek Water, 1980

\begin{tabular}{lccc}
\hline Nuclide & $\begin{array}{c}\text { Net Average } \\
\text { Concentration } \\
(10-9 \mu \mathrm{C} / \mathrm{mL})\end{array}$ & $\begin{array}{c}\text { Dose } \\
(\mathrm{mrem} / \mathrm{yr})\end{array}$ & $\begin{array}{c}\text { Percent of } \\
\text { Standard }\end{array}$ \\
\hline Hydrogen-3 & 118 & 0.020 & 0.004 \\
Strontium-90 & 0.06 & 0.6 & 0.020 \\
Neptunium-237 & 0.010 & 0.01 & 0.0003 \\
Plutonium-238 & 0.0062 & 0.0037 & 0.00012 \\
Plutonium-239 & 0.0110 & 0.0066 & 0.00022 \\
Americium-241 & 0.0057 & 0.0021 (kidney) & 0.00014 \\
Curium-244 & 0.0022 & 0.0034 (bone) & 0.00011 \\
Californium-249 & 0.0022 & 0.0009 (bone) & 0.00003 \\
\hline
\end{tabular}

Source: Golchert et al. (1981). 


\subsection{Direct Radiation}

The external radiation exposure (plus whole body internal for hydrogen-3) to monitored personnel at ANL for the period 1974 through 1980 is summarized in Figure 3.2. The figure also indicates a breakdown by type of activity as indicated in the key. It is evident that within this time span there has been a significant downward trend in radiation exposure at ANL. This trend has been due primarily to changes in programmatic activities (e.g., the shutdown of the $2 G S$ accelerator and $C P-5$ research reactor) and an aggressive effort to implement the "As Low As Reasonably Achievable" (ALARA) exposure control philosophy. It is anticipated that further reductions in radiation exposure will not be as dramatic as those noted in the past, due to the fact that there are certain renewed activities involving sources of radiation (e.g., increased levels of use in various hot cells and the $2 P R$ reactor, mothballing of the CP-5 reactor, dismantling of the ZGS complex, and disposal of plutoniumcontaminated gloveboxes in Bldg. 350). General ANL criteria are aimed at limiting radiation exposure to onsite personnel to a total of 100 person-rem/ year, with a maximum of 1.5 rem to any individual.

At two locations along the ANL perimeter fence, penetrating gamma radiation levels were found to be consistently higher than the normal background range of 80 to $104 \mathrm{mrem} / \mathrm{yr}$. For the first half of 1977 , the dose rate at a location in the center of the north perimeter averaged $265 \mathrm{mrem} / \mathrm{yr}$; however, a relocation of two cobalt sources in $B 1 d g .202$ reduced this level to about $130 \mathrm{mrem} / \mathrm{yr}$ in 1980 . At another location on the south boundary, the levels averaged about $650 \mathrm{mrem} / \mathrm{yr}$ in 1980 . This dose rate was attributed to the radwaste holding area, Facility 317. Radiation levels at this location were higher than normal levels measured over the past several years because wastes were retained for longer periods before disposal in 1980 , due to restrictions on shipping of wastes to the main ANL disposal site in Idaho. Both offsite locations indicated above are within the Waterfall Glen Forest Preserve and are remote from any residence. Monitoring results from a station about $180 \mathrm{~m}$ south of the latter location showed normal readings, indicating a relatively short range of the radiation. The maximum calculated dose to an individual at the nearest residence is less than $0.1 \mathrm{mrem} / \mathrm{yr}$ (Golchert et al. 1981). Additionally, because shipping restrictions were lifted in 1981, ANL has accelerated removal of radwastes from the 317 area; this will reduce radiation from this site to levels closer to background.

Truck transport of ANL wastes results in low-level exposure to workers and the exposed public. Doses due to transport are estimated as about $4 \mathrm{mrem} / \mathrm{yr}$ to transport workers, $0.03 \mathrm{mrem} / \mathrm{yr}$ to an individual, and $0.9 \mathrm{person}-\mathrm{rem} / \mathrm{yr}$ to the public.

\subsection{Well Water Radioactivity}

Radiological data for the ANL domestic wells have been collected monthly since 1970. Hydrogen-3 in Well $\equiv_{1} 1$ is the only radioactive substance ever found in any of the four wells. The hydrogen-3 concentration in this well was about 4,000 pCi/L in 1970 and has been gradually declining ever since. The concentration of recent samples was about $400 \mathrm{pCi} / \mathrm{L}$. All other wells have less than $200 \mathrm{pCi} / \mathrm{L}$, the limit of detection. The hydrogen-3 content in Well 非 is considerably less than the maximum allowable concentration for drinking water of $20,000 \mathrm{pCi} / \mathrm{L}$ established by the U.S. Environmental Protection Agency. 


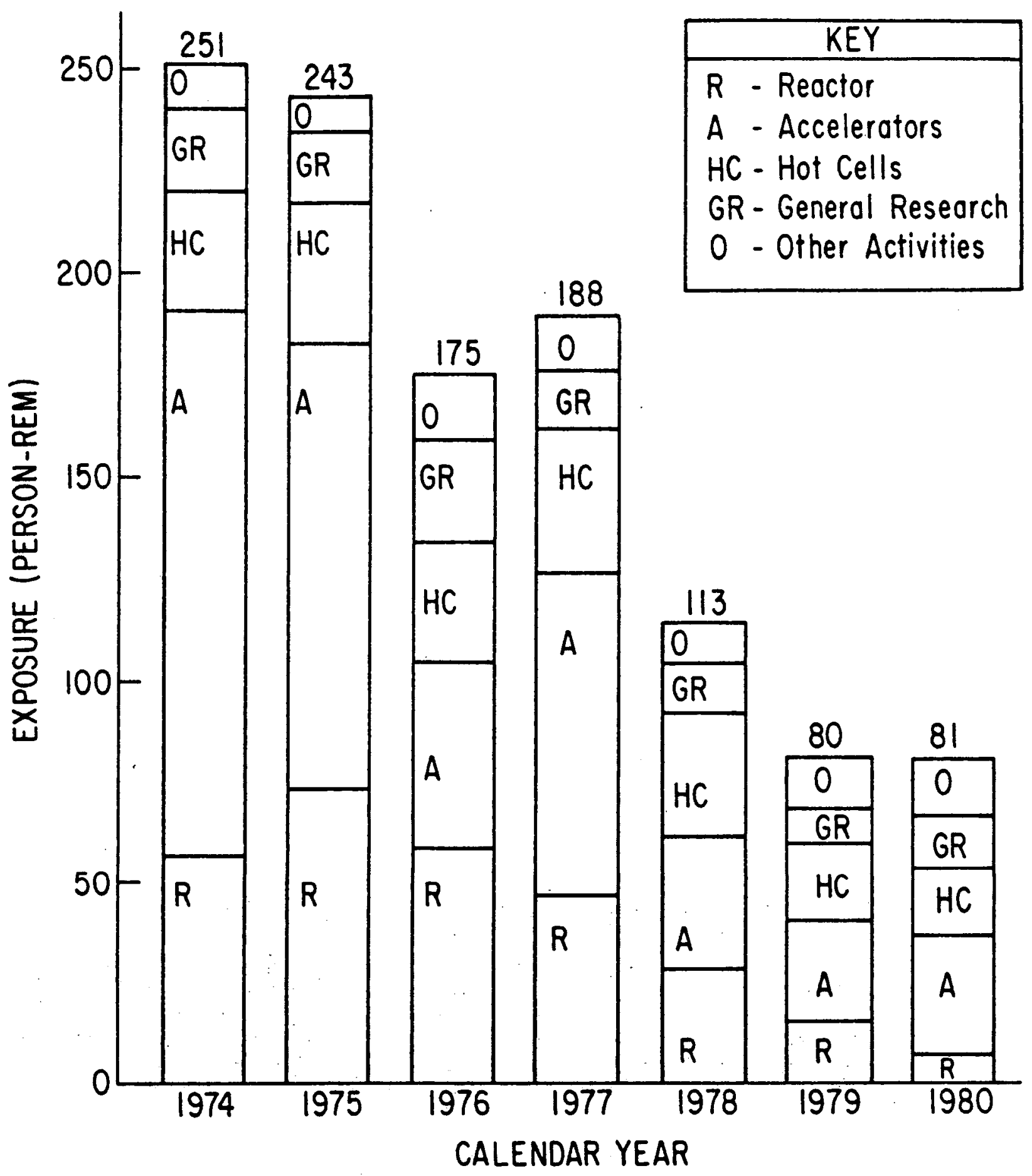

Figure 3.2. Radiation Exposure to Monitored Personnel at ANL, 1974-1980. 
There is no obvious explanation for the elevated level in Well 非. Elevated hydrogen-3 in surface waters (approximately $245 \mathrm{pCi} / L$ ) occurred during 1952 in the United States due to nuclear weapons testing. However, this would not account for the elevated level in Well 非 1 .

\subsection{IMPACTS DUE TO PREEMPTION OF NATURAL RESOURCES}

In this section, the environmental impacts of ANL operation associated with natural resource preemption are discussed. The resources considered are land, water, and energy.

\section{2 .1 Land}

The original 1514 ha of ANL were largely low-quality farmland, forests, marshes, and an estate of moderate size. Exact descriptions of the land productivity are not available; however, comparisons of the ANL area with similar areas near the Illinois Waterway indicate a generally low level of agricultural and other use of the land. In 1973, 826 ha of the original area was transferred to DuPage County for use as a forest preserve, leaving the Laboratory with the presently occupied 688 ha.

Based on a comparison of the ANL site with nearby similar areas and the current trends in land use, it could be expected that without ANL the area would probably be developed as a low-density residential or light industry area. The essential impact of ANL is one of decreasing the space available for low-density residences. The proper balance of land uses promoted in the DuPage County land-use plan (DuPage Co. Region. Plan. Comm. 1978) calls for a greater area in both the "office, research and development" category, represented by ANL, as well as the "open space" of the forest preserves and the ANL site proper. Thus, the current ANL land usage is optimum with respect to the county land-use plan. Aside from the sanitary solid waste disposal area, there is little of the land area and few of the buildings that could not be converted to other uses if necessary.

\section{2 .2 Water}

The water systems of ANL comprise the potable/laboratory supply obtained from four wells in the Niagaran aquifer and the cooling water supply obtained from the Chicago Sanitary and Ship Canal. The well pumpage has created a small cone of depression beneath the site; however, the general water level outside the site has been unaffected by the ANL pumping. The use of well water at ANL averages about $1.4 \times 10^{4} \mathrm{~m}^{3} / \mathrm{yr}$, which may be compared with the county usage from the same aquifer of $5.7 \times 10^{6} \mathrm{~m}^{3} / \mathrm{yr}$ industrial, and $6.1 \times 10^{7} \mathrm{~m}^{3} / \mathrm{yr}$ total (Benson 1978). The ANL usage is therefore about $0.023 \%$ of the total county usage.

The cooling water system uses about $7.1 \times 10^{5} \mathrm{~m}^{3} / \mathrm{yr}$, which is about $0.025 \%$ of the Chicago Sanitary and Ship Canal flow. This water is evaporated in cooling towers or is discharged as noncontact cooling water or blowdown water to NPDES effluent points. The water returned to the Des Plaines River and Sanitary Canal (via discharge to Sawnill Creek) from the ANL treatment plant has at least similar (and probably higher) quality as the canal water withdrawn; the impacts of canal water use are therefore not deleterious. 


\section{2 .3 Energy}

ANL uses energy for space heating, air conditioning, lighting, and transportation in a manner similar to that of any other comparable commercial or office operation. In addition to these ordinary uses, energy is required for operating machinery involved in development processes, particle accelerators and laboratory apparatus of many kinds, motors for ventilation fans and pumps, and many other purposes. The impacts of the gaseous and liquid effluents resulting from energy use are discussed in Section 3.1.3. This section is concerned only with the impacts of the energy use on the natural resources required to produce the energy, and on other potential consumers of the energy.

For the years 1973 through 1977, the average use of natural gas was about $3.4 \times 10^{7} \mathrm{~m}^{3} / \mathrm{yr}$ with an approximate $10 \%$ reduction obtained in the years 1976 and 1977 from the peak year of 1975. This consumption amounts to about $0.16 \%$ of the total gas consumption for the six northeastern Illinois counties, and about $0.5 \%$ of the industrial gas used (Northeast. Ill. Plan. Comm. 1977). The Laboratory is allotted a maximum quantity of natural gas $\left(4.57 \times 10^{12} \mathrm{~J} / \mathrm{d}\right)$, and when demand exceeds the allotment, \#2 fuel oil is burned. In 1977, about $3,250 \mathrm{~m}^{3}$ of oil were burned, accounting for about $10 \%$ of the total heating fuel used at ANL and $0.03 \%$ of the nontransportation use of petroleum fuels in the northeastern Illinois counties. The boilers are also equipped to burn 非 (residual) fuel oil, but this has not been done for several years. One of the five boilers, with one-third of the total capacity, has recently been converted to the use of high-sulfur coal. This conversion will result in the use of 45,000 metric tons of coal per year, but will replace the consumption of $3 \times 10^{7} \mathrm{~m}^{3}$ of natural gas and up to $2900 \mathrm{~m}^{3}$ of fuel oil.

The use of natural gas, although significant, is consistent with the total employment at ANL, and can presumably be justified in terms of the work that is done.

In the years 1973 to 1977 , ANL consumed an average of about 248 million $\mathrm{kWh} / \mathrm{yr}$ of electrical energy, of wich the $2 \mathrm{GS}$ used about $62 \%$. In 1980 , the ZGS was closed down, substantially reducing the total. ANL electric power consumption.

The annual electricity consumption for ANL has amounted to about $5 \%$ of the capacity of the nearest Commonwealth Edison Company generating station (Will County station), and about $0.5 \%$ of the total company capacity (Elec. World 1976). These uses of electricity are significant; however, the basic fuels used, uranium and coal, are not currently scarce and ANL usage does not lead to an excessive consumption of natural resources or to the deprivation of other users. 


\subsection{ADDITIVE IMPACTS}

This section addresses additive impacts that may result from the combined releases from ANL and other sources in the region.

\subsubsection{Nonradioactive}

DuPage County, in which ANL is located, is part of Air Quality Control Region 67. Air particulate matter data reported in this region (I1l. Environ. Prot. Agency 1976) indicate that about one-third of the sampling sites exceed the primary air particulate standard of $75 \mu \mathrm{g} / \mathrm{m}^{3}$. Annual geometric means for DuPage County sampling sites range from about 50 to $110 \mathrm{\mu g} / \mathrm{m}^{3}$. Average values at ANL usually range from 40 to $60 \mu \mathrm{g} / \mathrm{m}^{3}$. Thus, there is no significant additive impact of ANL operations on regional air particulate matter. With respect to $\mathrm{NOx}$ and $\mathrm{SO}_{2}$ from the boiler plant, at the nearest residence, about $1.1 \mathrm{~km}$ away, ANL contributes about $20 \%$ of the ambient and $1 \%$ of the state standard for $\mathrm{SO}_{2}$, and $15 \%$ of the ambient and $10 \%$ of the state standard for NOx. In other directions and at greater distances, the ANL contribution would generally be undetectable.

In general, the ANL effluent water quality is similar to that of Sawmill Creek. The main dry-weather flow to the creek upstream of ANL is the effluent from a municipal sanitary waste treatment plant. There is no significant additive impact of ANL effluent on the quality of Sawmill Creek or the Des Plaines River.

\subsubsection{Radioactive}

Currently, there are no major nuclear facilities sufficiently near ANL to cause any measurable additive impacts from combined airborne or liquid effluent. streams. In this section, therefore, the additive impact of ANL on other radiation-producing facilities in the Chicago metropolitan area is discussed.

Fermi National Accelerator Laboratory (Fermilab), located about $24 \mathrm{~km}$ northwest of ANL, has a proton synchrotron capable of accelerating protons to $500 \mathrm{GeV}$; it is routinely operated at $400 \mathrm{GeV}$. Direct radiation from the accelerator operation is in the northeast direction, resulting in an annual dose of about 7 mrem at the Fermilab site boundary (Baker 1978). The direction of the beam is away from ANL. The calculated dose at the Fermilab site boundary for airborne radioactivity is $0.3 \mathrm{mrem}$, primarily from carbon- 11 . The calculated maximum dose from ANL airborne effluents at Fermilab is about $0.004 \mathrm{mrem} / \mathrm{yr}$. The total amount of activity in liquid effluents released by Fermilab to surface waters was less than $0.1 \mathrm{Ci}$. Both the Fermilab and ANL discharges of treated radiological wastes in liquid effluents are ultimately discharged to the Illinois River.

The Dresden nuclear power complex is located about $48 \mathrm{~km}$ southwest of ANL and consists of one 200-MWe and two 800 -MWe light water reactors (LWRs). The Midwest Fuel Recovery Plant is located adjacent to the Dresden station within the security perimeter. During a representative year, a total of $8.9 \times 10^{5} \mathrm{Ci}$ of gaseous effluents would be released to the atmosphere from Dresden (Commonw. Edison. Co. 1975a). The highest dose is calculated to be about $12 \mathrm{mrem} / \mathrm{yr}$. The dose from ANL effluents at this point is calculated to be about $0.002 \mathrm{mrem} / \mathrm{yr}$. 
Liquid effluents released from Dresden usually consist of about $54 \mathrm{Ci}$ of hydrogen-3 and $1.7 \mathrm{Ci}$ of other materials. These liquids are discharged into the Illinois River into which ANL releases also flow. Monitoring of the Illinois River by ANL indicates that there is no measurable additive impact of any radionuclide from ANL.

The Zion nuclear power station is located on Lake Michigan about $80 \mathrm{~km}$ north-northeast of ANL. The station consists of two 1100-MWe LWRs which use lake water for once-through cooling. A total of about $4.5 \times 10^{4} \mathrm{Ci}$ of noble gases is normally released to the atmosphere. The dose from these releases is estimated to be $0.1 \mathrm{mrem} / \mathrm{yr}$ to the nearest occupied area, compared to a dose of about $0.005 \mathrm{mrem} / \mathrm{yr}$ at this point from ANL releases.

About $40 \mathrm{Ci}$ of hydrogen-3 is discharged from the Zion station into Lake Michigan as liquid effluents (Commonw. Edison Co. 1975b). No ANL liquid effluents are discharged into Lake Michigan.

The Quad Cities station is located on the Mississippi River about $200 \mathrm{~km}$ west of ANL and consists of two 800-MWe LWRs. The airborne releases are similar to those from the Dresden station and any ANL contribution would be insignificant at this distance. Liquids are discharged into the Mississippi River.

No other nuclear power reactors are currently planned that would be closer to ANL than Dresden and Zion.

\subsection{IMPACTS OF POSSIBLE ACCIDENTS}

\subsubsection{Introduction}

From its inception, the U.S. atomic energy program has placed a premium on personnel and equipment safety. In its more than 30-yr existence, ANL accidental personnel deaths and serious injuries are attributable exclusively to "conventional" causes, e.g., electrocution, falls, etc., rather than to the uncontrolled release of radioactivity or toxic chemicals.

In the following section, potential accidents are categorized by type and, within each type, one or two specific facilities are selected for analysis of environmental impact. The facilities. selected are those for which the risk of the particular accident would be greatest. In selection of these facilities, consideration was given to the types and quantities of materials presenting greatest hazard upon release to the environment. The structural integrity of the facilities to withstand natural disasters, wherever applicable, was also considered. In all cases, however, the analyses are based on a realistic approach, emphasizing a credible scenario of events.

\subsubsection{Classification of Accidents}

For the purposes of this assessment, potential accidents in experiment and support facilities have been grouped into a few major categories. These categories are generally typical of the wide spectrum of accidents that might reasonably be postulated to occur in a research institution of ANL's size and diversity. In this section, the various accident categories are briefly 
described. In the next section, specific accidents in each category are analyzed.

\subsubsection{Explosions}

Several ANL organizations use or store chemicals that, under certain abnormal conditions, could explode. In general, the consequences of such explosions would be limited to the immediate area, possibly including personnel injuries as well as damage to facilities. However, if an explosion were to occur in a facility in which radioactive or toxic materials were present, these materials might be dispersed to and beyond the site boundary. In this case, the potential environmental impact must be evaluated.

\subsubsection{Fires}

Virtually all ANL research and support groups routinely employ flammable and/or combustible materials in their operations. These range from the common flammable solvents utilized in all chemical laboratories to computer paper to molten sodium. In spite of the fire-prevention measures that are an integral part of the ANL safety program, fires.can and do occur; however, in the more than 30-yr history of ANL, there has never been a fire of significant. consequence.

As in the case of explosions, most of the harmful effects of a fire would be localized at the fire site. However, a large enough fire might conceivably generate a combustion-product aerosol (possibly containing toxic and/or radioactive material) whose effects could be felt beyond the site boundary.

\subsubsection{Accidental Criticality}

Whereas fires and explosions can generally be considered "conventional" hazards, facilities that use or store fissile material (e.g., uranium-235 and plutonium-239) must be designed to prevent accidents that are peculiar to such facilities. The design and construction of reactors and fissile material storage facilities, the training of operating personnel, and the development of operating policies and procedures are all aimed, inter alia, at preventing accidental (i.e., unplanned) criticality or positive reactivity additions.* For example, for ANL-operated reactors, it would require the unlikely combination of several independent human and/or instrument malfunctions to achieve unwanted criticality. Furthermore, even if such criticality were attained,

\footnotetext{
* Positive reactivity addition means that some change in configuration is effected, causing the neutron multiplication (and hence, power) to increase as a function of time. In a reactor, if this increase were not checked by inherent or active protective features, or some combination of both, the core would eventually be destroyed. Typical means of adding reactivity to a core include: adding fissile material, removing neutron "poison" material (e.g., control rods), and replacing certain materials with more "reactive" materials. In a fissile material storage facility, accidental criticality might be achieved by defeating administrative and/or physical controls such as those designed to limit material quantities or maintain safe separation between fissile material assemblages.
} 
the consequences would be limited by inherent (i.e., passive) shutdown features or multiple, redundant instrumentation systems, or both. A detailed analysis of this generic accident is presented in Section 3.4.3.3.

\subsubsection{Spills}

Included in this category are accidental releases of chemical, radioactive, and toxic materials that might have an impact on the environment. Specifically, the releases considered here are exclusive of those due to explosions or fires.

\subsubsection{Natural Phenomena}

Accidents in this category are those that result from the incidence of severe natural phenomena, e.g., tornadoes. Potential offsite dispersion of harmful materials contained in facilities subject to damage from such phenomena is considered.

\subsubsection{Accident Analysis and Consequences}

In this section, specific accidents are analyzed to determine their offsite environmental effects. In all cases, a representative accident was chosen in each category on the basis that its impact would be a probable upper bound for all impacts from similar accidents in the same category. In selection of these accidents, consideration was given to the types and quantities of materials presenting greatest hazard upon release and to structural integrity of the facilities to withstand natural disasters. Models and data used for atmospheric dispersion and dose calculations are described in detail in Appendix B. Onsite consequences have been anticipated, and appropriate plans have been developed for each Laboratory facility to mitigate the consequences of an accident.

\subsubsection{Explosions}

Laboratory explosions are considered credible, although standard ANL safety policies and practices address recognized explosion hazards by promulgating appropriate design and operating requirements intended to minimize their occurrence (cf. Argonne Natl. Lab 1973). For the purpose of this assessment, two glovebox explosions involving subsequent plutonium dispersal have been considered: a chemical explosion in an NBL plutonium facility and a hydrogen explosion in an MSD sintering furnace. These two facilities were chosen because they provide reasonable upper limits on the amount of plutonium that might conceivably be at risk in an explosion. No programmatic changes are currently foreseen that would alter this conclusion.

\subsection{NBL Glovebox Explosion}

Although the amounts and types of solvents in gloveboxes are limited, an explosion is assumed to occur with the subsequent release of airborne plutonium to the environment. The plutonium used in the calculations is representative of the most hazardous material expected to be received (i.e., from LWR recycle) and is not typical of current operations. The isotopic composition of the plutonium is as follows: $238-2 \% ; 239-58 \% ; 240-23 \% ; 241-12 \%$; and $242-5 \%$. 
It is assumed that a typical maximum quantity of $10 \mathrm{~g}$ of plutonium in a glovebox is involved in an explosion, resulting in its total conversion to fine airborne particulates. It is further assumed that $1 \%$ of the particulates reaches the filter.* An attenuation factor of 200 is conservatively assumed for the filter system. The resulting quantity of plutonium released from the building is $500 \mathrm{\mu g}\left(10 \times 0.01 \times 5 \times 10^{-3} \times 10^{6}\right)$. This plutonium is assumed to be released as a single puff at ground level, although there is actually a $34-m$ stack for atmospheric dilution. Since the plutonium may be in either a soluble or insoluble form, doses were calculated for both cases (Table 3.10).

Table 3.10. Lifetime Dose Commitment Following NBL Glovebox Explosion

\begin{tabular}{lccccc}
\hline & \multicolumn{4}{c}{ Dose Commitment } \\
\cline { 2 - 3 } & $\begin{array}{c}\text { Maximum } \\
\text { Individual } \\
\text { Orrem) }\end{array}$ & $\begin{array}{c}\text { Population } \\
\text { (person-rem) }\end{array}$ & & $\begin{array}{c}\text { Maximum } \\
\text { Individual } \\
\text { (mrem) }\end{array}$ & $\begin{array}{c}\text { Population } \\
\text { (person-rem) }\end{array}$ \\
\hline Lung & $\mathrm{NA}^{\mathrm{b}}$ & NA & & 0.03 & 10.6 \\
Bone & 1.2 & 424. & & 0.6 & 212. \\
Liver & 0.13 & 46. & 0.07 & 24.7 \\
GI tract & $7 \times 10-6$ & 0.002 & & $9 \times 10-6$ & 0.003 \\
\hline
\end{tabular}

${ }^{a}$ Within a radius of $80 \mathrm{~km}$.

${ }^{b}$ Not applicable.

\subsection{MSD Glovebox Explosion}

Hydrogen furnaces are used by MSD to sinter plutonium oxide powders into pellets. Although the furnaces are located within inert-gas-filled gloveboxes, an explosion is nevertheless assumed to somehow occur. Since the oxide powders have a large size distribution (from 100 to $350 \mu \mathrm{m}$ ), the only airborne plutonium hazard arises from the loose glovebox surface contamination. This is estimated to be a maximum of $0.1 \mathrm{~g}$ of plutonium-239 oxide. According to conservative engineering judgments, if it is assumed that $10 \%$ of the contamination is ejected from the glovebox, $50 \%$ remains airborne, $50 \%$ of the airborne particles are of respirable size, and HEPA filter penetration is $0.1 \%$ plutonium-239 released to the environment as oxide will be $2.5 \mu \mathrm{g}(0.1 \times 0.1$ $\left.\times 0.5 \times 0.5 \times 0.001 \times 10^{6}\right)$. The dose commitments calculated for a ground-level puff release are shown in Table 3.11. It is highly improbable that more than

\footnotetext{
*Assumption of $1 \%$ is based on discussion presented in the report of Argonne National Laboratory (1977c).

wSee filter discussion in Section 3.4.3.2.1.
} 
Table 3.11. Lifetime Dose Commitment Following MSD Glovebox Explosion

\begin{tabular}{lcc}
\hline & \multicolumn{2}{c}{ Dose Commitment } \\
\cline { 2 - 3 } Organ & $\begin{array}{c}\text { Maximum } \\
\text { Individual } \\
\text { (mrem) }\end{array}$ & $\begin{array}{c}\text { Population } \\
\text { (person-rem) }\end{array}$ \\
\hline Lung & $1.6 \times 10-5$ & 0.006 \\
Bone & $3 \times 10-4$ & 0.11 \\
Liver & $4 \times 10-5$ & 0.014 \\
GI tract & $4 \times 10-9$ & $1.4 \times 10-6$ \\
\hline
\end{tabular}

${ }^{\text {a }}$ Within a radius of $80 \mathrm{~km}$.

$50 \%$ of the plutonium will remain airborne for any significant length of time; but even if this were the case, the doses received by the individuals and the population would still be of minimal consequence.

\subsubsection{Fires}

Although no credible mechanisms have been identified that could initiate a fire having significant offsite consequences, the results of large fires in fissile material storage facilities are nevertheless calculated in this section. A review of ANL facilities that might pose such a fire threat resulted in consideration of two specific cases that bound all similar risks at ANL: a uranium metal fire in the Bldg. 33lA vault; and a plutonium metal fire in one of the Bldg. 350 vaults.

\subsection{Uranium Fire}

It is conservatively assumed that the entire inventory of uranium metal in a single storage container ignites and burns. This inventory totals $16 \mathrm{~kg}$ and has the following isotopic composition: $234-2 \% ; 235-95 \% ; 236-2 \%$; and $238-1 \%$.

of the material burned, $0.05 \%$ is assumed to become airborne within the vault and available for release to the environment (Carter et al. 1960). Since the vault exhaust system contains. a single HEPA filter, the uranium oxide release is reduced from the amount that is airborne by a factor of 1000 , i.e., the filter efficiency is assumed to be $99.9 \%$. This is much lower than the acceptance efficiency of HEPA filters, which is $99.97 \%$. The latter would provide an attenuation factor of more than 3300 ; it is also the efficiency required by ANL in its in-place HEPA filter testing program (Argonne Natl. Lab. 1973). The net result is that a total of about $8 \mathrm{mg}$ of uranium, as oxide, is released $\left(16 \times 0.0005 \times 0.001 \times 10^{6}\right)$. For added conservatism, a ground-level release is assumed, although the exhaust is actually via a 10-m stack. 
Since the uranium-oxide effluent is insoluble, the critical organ for inhalation is the lung. The results of the dose calculations for selected organs are given in Table 3.12 .

Table 3.12. Lifetime Dose Commitment Following a Uranium Fire

\begin{tabular}{lcc}
\hline & \multicolumn{2}{c}{ Dose Commitment } \\
\cline { 2 - 3 } Organ & $\begin{array}{c}\text { Maximum } \\
\text { Individual } \\
\text { (mrem) }\end{array}$ & $\begin{array}{c}\text { Population } \\
\text { (person-rem) }\end{array}$ \\
\hline Lung & $3.4 \times 10-5$ & 0.0112 \\
Bone & $6.7 \times 10-6$ & 0.0024 \\
GI tract & $2.4 \times 10-8$ & $8.5 \times 10-6$ \\
\hline a Within a radius of $80 \mathrm{~km}$. &
\end{tabular}

\subsection{Plutonium Fire}

A single plutonium storage container may hold up to $4.5 \mathrm{~kg}$ of plutonium metal. For this analysis, it is conservatively assumed that the entire $4.5 \mathrm{~kg}$ ignites and burns. The plutonium is assumed to have the following isotopic composition: $238-0.1 \% ; 239-70.9 \% ; 240-24 \% ; 241-4 \%$; and $242-1 \%$. Since plutonium-241 decays with a relatively short half-life to americium-241, the calculations are performed for both isotopes, i.e., $4 \%$ of the material is assumed to be either plutonium-241 or americium-241. In this way, the results bound the true value that would be obtained if the exact percentages of each isotope were known and used in the calculation.

As in the uranium fire, it is assumed that $0.05 \%$ of the burned plutonium becomes airborne (Carter et al. 1960). Since ANL plutionium storage facilities have air exhaust systems that contain two HEPA filters in series, the combined effluent-reduction factor is taken as $5 \times 10^{5}$. This number is based on a first-filter efficiency of $99.9 \%$ and a second-filter efficiency of $99.8 \%$. These efficiency values are significantly lower than those that have been documented for similar facilities (Gonzales et al. 1976; U.S. Energy Res. Dev. Admin. 1977a). Applying the various factors noted above, the total amount of plutonium (or plutonium-americium mixture) released as oxide is $4.5 \mathrm{\mu g}$ $\left(4.5 \times 0.0005 \times 2 \times 10^{-6} \times 10^{9}\right)$. The results of the dose calculations are given in Table 3.13 .

\subsubsection{Accidental Criticality}

In this section, analyses of accidental criticality of, or unplanned reactivity addition to, critical systems for the four ANL reactors are presented. In most cases, the treatment of the accident is based on a credible sequence of events, even though the accident initiation event may be extremely 
Table 3.13. Lifetime Dose Commitment Following a Plutonium Fire

\begin{tabular}{|c|c|c|c|c|}
\hline \multirow[b]{3}{*}{ Organ } & \multicolumn{4}{|c|}{ Dose Commitment } \\
\hline & \multicolumn{2}{|c|}{$\begin{array}{l}\text { Plutonium- } 241 \\
\text { in Effluent }\end{array}$} & \multicolumn{2}{|c|}{$\begin{array}{l}\text { Americium- } 241 \\
\text { in Effluent }\end{array}$} \\
\hline & $\begin{array}{l}\text { Maximum } \\
\text { Individual } \\
\quad \text { (mrem) }\end{array}$ & $\begin{array}{c}\text { Population } \\
\text { (person-rem) }\end{array}$ & $\begin{array}{l}\text { Maximum } \\
\text { Individual } \\
\quad \text { (mrem) }\end{array}$ & $\begin{array}{c}\text { Population } \\
\text { (person-rem) }\end{array}$ \\
\hline Lung & $6 \times 10-5$ & 0.021 & $8 \times 10-5$ & 0.028 \\
\hline Bone & $1.7 \times 10^{-3}$ & 0.60 & $1.4 \times 10^{-3}$ & 0.49 \\
\hline Liver & $1.8 \times 10-4$ & 0.064 & $2.8 \times 10-4$ & 0.099 \\
\hline GI tract & $2.3 \times 10^{-8}$ & $8.1 \times 10.6$ & $3.1 \times 10-8$ & $1.1 \times 10-5$ \\
\hline
\end{tabular}

unlikely. These analyses, therefore, are distinguished from the familiar Design Basis Accidents in that the latter

"are used, together with highly conservative assumptions, as the design-basis events to establish the performance requirements of engineered safety features. The highly conservative assumptions and calculations used in ... safety evaluations are not suitable for environmental risk evaluation, because their use would result in a substantial overestimate of the environmental risks. For this reason, (these) events shall be evaluated realistically. Consequences predicted in this way will be far less severe than those given for the same events in safety analysis reports where more conservative evaluations are used" (U.S. Nucl. Reg. Comm. 1976).

The following analyses are consistent with the requirements imposed on NRClicensed power reactors.

\subsection{Argonne Thermal Source Reactor}

The maximum excess reactivity available to the operator at the Argonne Thermal Source Reactor (ATSR) console is $0.5 \% \Delta k / k \%$. (Argonne Natl. Lab. 1976). Under conservative assumptions, the full $0.5 \% \Delta \mathrm{k} / \mathrm{k}$ would be inserted instantaneously with all the automatic reactor shutdown circuits inoperative. The reactor would then double in power.every 2 seconds, and the power level would rise until an equilibrium temperature is reached, this limit being due to the fact that the ATSR is naturally less reactive at higher temperatures. This equilibrium temperature is only about $75^{\circ} \mathrm{C}$, and it would take about $100 \mathrm{~s}$ to

*This means that there is an approximately $0.5 \%$ excess of neutrons to sustain the chain reaction at a constant rate. 
reach that level. Based on the Borax-I* experiments (Dietrich 1954), this power increase would result in a maximum fuel plate surface temperature of less than $115^{\circ} \mathrm{C}$. This type of transient is sufficiently slow so that any of the manual shutdown mechanisms could be activated before the equilibrium temperature is reached. Nevertheless, even without the intervention of positive shutdown devices, no damage would occur to the reactor or its core. Consequently, no radioactive material would be released to the environment.

\subsection{JANUS Reactor}

A conservative calculation was performed to assess the effects of a positive reactivity insertion on the JANUS fuel elements. System flow rate and temperature were chosen at their limiting (i.e., most conservative) values, reactor power and power level trip settings at the start of the transient were $25 \%$ higher than authorized, and a control rod was assumed to be driven out of the core. Even under these conditions, the minimum burnout ratio was 1.50 (Argonne Natl. Lab. 1977a), far above the fuel element incipient damage limit (1.0).

\section{$3 \cdot 4 \cdot 3 \cdot 3 \cdot 3 \quad 2 P R-6$ and $2 P R-9$}

As noted above, the ZPR- 6 and $2 P R-9$ critical facilities are essentially identical. Differences in analyses related to specific programs are due exclusively to the program and not to characteristics of the machine in which the program is executed. Since the operation of ZPR-6 and ZPR-9 may require frequent core loading changes, unlike the other ANL reactors that have essentially invariable core configurations, the potential clearly exists for errors that might lead to operational accidents. Following is a brief discussion of how ZPR operations act to guard against such errors.

The 2PR-6 and ZPR-9 facilities employ the following measures to prevent a nuclear accident:

1. Highly trained, skillful personnel are employed for judgment and operational functions. Operation of the ZPRs with uranium- and plutoniumfueled large dilute fast cores since 1963 and 1970 , respectively, has provided trained and experienced personnel for the safe operation of these systems.

2. Strict administrative procedures are enforced for controlling loading changes and operation, with periodic review and inspection of the operation. Details on loading procedures and safeguards are given above in Section 2.1.4.3.

3. Well-designed, reliable, fail-safe mechanical and electrical equipment and interlocks are used; frequent maintenance and testing are carried out.

4. Only assemblies that have inherent calculated negative power coefficients are constructed.

*The characteristics of the ATSR and Borax-I cores are essentially identical. 
In practice, there are three general lines of defense against criticality accidents. These are:

1. Great care is used in preparing an assembly for investigation. The loading operations are broken into many steps that are separately checked, so that a major loading error would require a significant error in the initial calculations, blind acceptance of the preloading evaluation by the Reactor Manager and the Assembly Coordinator, and the absence of suitable precritical multiplication checks. Such complete breakdown of administrative procedures is not credible.

2. Caution is observed in approaching criticality and in operating the reactor for experimental runs. This human caution is supplemented by built-in design features, e.g., table drive-speed limitations, that prevent potentially unsafe operations. It is inconceivable that the reactor would be operated in such a way that all established procedures are completely disregarded and physical restrictions defeated. Therefore, as with the loading procedures, it is necessary to postulate a series of operational blunders, rather than a single violation, in order to invite trouble.

3. Trip and interlock circuits are used. The steps necessary to bring the assembly to criticality and operate it in a critical condition are limited by a number of interlocks and by neutron-monitoring instrumentation with trip circuits. Monitoring instrumentation and trip circuits are checked daily to minimize undetected malfunctions. It is not credible that all, or even a majority, of the trip and interlock circuits of the system will be inoperable at any given time; however, accidents must be considered that may arise from a partial failure of the circuits.

As a practical matter, a breakdown in at least two of these lines of defense would be necessary for a serious problem to occur. Because of these multiple levels of protection, it has proven impossible to postulate a credible accident that would have any environmental impact. Nevertheless, a number of possibilities for some undesirable combination of malfunctions were considered. For the worst case found, the postulated course of the accident was as follows. It was assumed that an experiment was underway to measure the effect of a gap greater than $7.6 \mathrm{~cm}$ between the halves for a $0.05-\mathrm{m}^{3}$ core containing about $75 \mathrm{~kg}$ of plutonium-239 and -241. Also, it was assumed that the following unusual circumstances occurred. First, contrary to operating restrictions, the two period amplifiers with their associated trip circuits were bypassed, and the linear flux-level trip as well as both high-level safety trips were set approximately two decades above their normal trip level settings, thereby preventing scram until the neutron density reached a much higher level than would be normal. The operator then drove the movable table toward the stationary table at a rate of $0: 25 \mathrm{~cm} / \mathrm{s}$. "Thus, reactivity was added at a high rate and a nuclear excursion followed. Since the period trip circuits were assumed bypassed, the excursion continued; and because the level and safety trips were assumed to be set about two decades above their normal operating points, the excursion was not sensed until the reactor had become prompt-critical. The almost vertically rising power following prompt-critical then actuated the level trip circuit or the safety trip circuits and shutdown action was initiated. This starts the removal of the dual-purpose control/safety rods and, initially, stops the forward motion of the table. The table then begins to move backward a short time after the shutdown operation has started. 
The consequences of such a reactor excursion were calculated for two cases (Kato et al. 1970): (1) only the fuel plates are heated during the excursion, and (2) all materials in the core are heated. The resulting fuel temperatures do not differ by much in the two cases, and in both, these temperatures are far below either the ignition point $\left(603^{\circ} \mathrm{C}\right)$ or the fuel-iron eutectic point $\left(650^{\circ} \mathrm{C}\right)$. Fuel temperatures were also calculated assuming that the negative reactivity feedback coefficients were halved. This $50 \%$ reduction is far outside the range of probable error for these coefficients. The resulting temperatures again posed no threat to fuel plate integrity. There is therefore no possibility of fuel ignition or fuel plate jacket failure; which is a prerequisite for the release of radioactive materials from the core.

For comparison, similar calculations were performed on a $3.5-\mathrm{m}^{3}$ core containing substantially greater quantities of plutonium-239 and -241 . Such a large, dilute assembly is much more typical of the cores of interest in the current ZPR program. For such cores, the consequences are of even less concern than for the $0.05-\mathrm{m}^{3}$ core. In practice, cores that may be assembled in $2 P R-6$ or ZPR-9 are restricted to those for which the maximum credible accident analysis results in maximum fuel temperatures (i.e., peak fuel temperatures with nominal negative feedback coefficients) no greater than about $350^{\circ} \mathrm{C}$.

The above accident was evaluated as the ZPR- 6 and 2PR-9 maximum credible accident, maximum in the sense that the bounds of credibility of the initiating mechanism were strained and also in the sense that the neutronic parameters were chosen so that the excursion resulted in the maximum possible energy release. However, the particular scenario analyzed was intended only to be illustrative of the combination of malfunctions that would be necessary to produce an accident of this kind. Other accident scenarios can be postulated but their consequences would not exceed those of the above maximum credible accident.

Both ZPR-6 and ZPR-9 ceased operations in July 1982. It is anticipated that all fuel will have been removed by October 1982 .

\subsection{Fissile Material Storage Facilities}

The storage (as distinguished from usage) of fissile material is primarily under the direct control of SPM. In addition, the NBL storage facilities are operated in Bldg. 350 by NBL personnel. However, since the NBL operations are comnensurate with those of ANL, there will be no further discussion of the former.

Controls for the prevention of inadvertent criticality and the analysis justifying those controls are documented in the Criticality Hazards Control Statement (CHCS) for storage operations. The CHCS defines the operations to be conducted and the types of materials involved, and describes the physical facilities; it establishes procedures and limits to ensure the criticality safety of those operations; it presents an analysis of the operations, procedures, and limits to demonstrate that they comply with generally accepted standards and criteria for criticality safety. The CHCS is reviewed by the ANL Criticality Hazards Control Committee and is approved by ANL management upon favorable recommendation of the committee. An annual reapproval of the statement is required. Criticality limits specified in the statement are 
conspicuously posted in the storage vaults. A copy of the CHCS is maintained at the location where operations covered by the statement are conducted. The SPM criticality safety representative is responsible to the SPM director for ensuring that criticality safety limits and requirements are strictly enforced. Periodic criticality safety appraisals and reviews of the operations are conducted by both ANL and DOE.

In addition to the detailed administrative requirements mentioned above, permanent and/or semipermanent physical measures are employed to ensure adequate separation between containers of fissile material. For example, storage racks are securely fastened so as to prevent overturning due to any credible initiating event.

Based on the above-mentioned administrative procedures in combination with physical provisions, no credible mechanisms have been identified that could lead to an accidental criticality in a fissile material storage facility. At ANL, fissile solutions are stored exclusively in two vaults located in Bldgs. 200 and 205. (NBL fissile solutions are stored in Bldg. 350.) Criticality safety is achieved by two means: maintaining limits on fissile mass concentration and limiting the number of stored units per unit of storage volume. The latter is especially enforced for solutions with high, though critically safe, fissile concentrations.

\section{4 .3 .4 Spills}

Included in the spill accident category are inadvertent releases for which no systematic causes could be identified. Specifically, an evaluation was made of the kinds of hazardous material that might be available in sufficient quantity and concentrated in one location such that a loss of containment of the material might present an offsite hazard. Materials considered in addition to radionuclides included chlorine, carcinogens, and pathogens. The results of this evaluation are given below.

\subsection{Nonradioactive Spill}

Applying the criteria of quantity, concentration, and potential hazard, it was concluded that a release of chlorine from a storage tank would be the most serious nonradioactive spill. Chlorine is used in large quantities for the treatment of potable and canal water and of effluent from the sewage treatment plant. The largest storage tank in use has a capacity of $900 \mathrm{~kg}$, and is located at the Canal Water Treatment Plant (Bldg. 583). If it is assumed that all the chlorine leaks from the tank in $20 \mathrm{~min}$, the maximum concentrations at the nearest site boundary $(\sim 0.4 \mathrm{~km})$ and at the nearest residence $(\sim 1.6 \mathrm{~km})$ are $1.2 \mathrm{mg} / \mathrm{m}^{3}$ and $0.5 \mathrm{mg} / \mathrm{m}^{3}$, respectively. These compare with a concentration of $40-60 \mathrm{mg} / \mathrm{m}^{3}$ that is "dangerous" for a $30-$ to $60-\mathrm{min}$ exposure (Patty 1962), and the permissible 8 -h average concentration of $3 \mathrm{mg} / \mathrm{m}^{3}$ for occupational workers (U.S. Occup. Saf. Health Admin. 197.8).

\subsection{Radioactive Spill}

Radioactivity is released to the environment in small amounts as a result of ANL operations (see Section 3.1.2.2). These releases may be either routine or unintentional. In the former category are the gaseous radionuclies continuously released from the reactor stacks; the latter are typified by the trivial 
amounts of radioactivity that are occasionally disposed in liquid drains and find their way to the environment via the suspect liquid waste systems. Ultimately, the liquid wastes are either discharged to Sawmill Creek if the levels are sufficiently low, or concentrated to form solid wastes for shipment offsite to a licensed burial facility. In either case, the environmental impact is trivial.

A review of laboratory operations involving radiation, as well as an inventory of radioisotopes, was conducted. Considering all factors having a bearing on the potential for a significant uncontrolled release of radioactivity to the environment, it has been concluded that there is no credible situation that might lead to such a release without the accompanying driving force of an explosion, fire, accidental criticality, or natural phenomenon (treated in Sections 3.4.3.1, 3.4.3.2, 3.4.3.3, and 3.4.3.5, respectively.)

One type of accident that might be loosely considered a spill is the release of cobalt-60 from the BIM Gammabeam-650 irradiator described in Section 2.1.4.9. It can be postulated that the thousands of irradiation cycles, each involving the rapid motion of source capsules through a source tube, result in a gradual undetected erosion of the capsule walls. Although no such problem has ever occurred in this type of irradiator and it is considered only remotely credible in any case, the result of such an event, leading to a loss of the two protective walls, has been estimated. (Note that the total capsule wall thickness is about $0.3 \mathrm{~cm}$.)

If it is assumed that all three capsules in a single source-tube string eventually lose their cobalt-containment capability, due perhaps to a defective source tube, then, at most, $4,500 \mathrm{Ci}$ of cobalt-60 could be considered at risk. Because of the nickel plating on the cobalt pellets, fragmentation of the pellets into respirable (i.e., micron-size) particles is unlikely. The amount of material exhausted to the environment can be estimated by assuming the following systematic source-depletion mechanisms:

(a) Fraction of material of respirable size $=1 \%$.

(b) Fraction of material leaving source tube vent hole and becoming airborne $=10 \%$.

(c) Fraction of airborne material entering room exhaust duct before settling $=10 \%$.

(d) Fraction of material in exhaust duct that leaves building $=25 \%$.

Combining the above numbers, the most cobalt-60 that might conceivably be released is $113 \mathrm{mCi}(4,500 \times 1000 \times 0.01 \times 0.1 \times 0.1 \times 0.25)$. Using the data and methods described in Appendix $B$, the highest individual dose commitment was calculated to be $0.06 \mathrm{mrem}$ to the lung. The corresponding population dose is only 21 person-rem.

\subsubsection{Natural Phenomena}

The natural hazards that have been considered in this statement are floods, earthquakes, and tornadoes. The following sections present an evaluation of the potential for accidents induced by these phenomena. 


\subsubsection{1'Floods}

The topography and surface hydrology of the ANL site and adjacent areas were briefly discussed in Section 2.2.1. The water treatment sludge pond proximal to the north boundary of the ANL site is separated from the adjacent Sawmill Creek floodplain by a man-made embankment that ensures the integrity of the pond during a 100-year flood event. The coal storage pad located immediately east of the central boiler house (Bldg. 108, Figure 2.8) is likewise protected from flooding by an embankment that has been constructed. The embankment is located immediately above the 100-year floodplain at $201.1 \mathrm{~m}$ MSL, and the crest of the structure is at a $202.7-\mathrm{m}$ elevation (Argonne Natl. Lab. 1980b), thus providing a safety margin in the event the 100-year flood level were exceeded. All major structures and facilities of the ANL site are either located above any reasonably predictable flood level or adequately protected from flooding during a 100-year or greater flood event. Further, those structures or facilities located within the potential floodplains--such as segments of road and boundary fencing, supports for aboveground steam distribution pipes, culverts, and bridges--are not considered to unduly impede overland flow during periods of flooding.

\subsection{Earthquakes}

Historically, earthquakes in the vicinity of the ANL site have been noted for their mildness. Indeed, ANL lies within Zone 1 on the Seismic Risk Map of the United States, which is the region of lowest seismic risk among those regions in which earthquake damage may occur (Int. Conf. Build. Off. 1976). In Zone 1 , earthquake intensities correspond to intensities of $V$ and $V I$ as measured on the Modified Mercalli (MM) Scale. At the higher of these intensities, damage is characterized as "slight in poorly built buildings" (Natl. Ocean. Atmos. Admin. and U.S. Geol. Surv. 1977).

The typical ANL laboratory/office building is of reinforced concrete and masonry construction, with closely spaced columns and a low, rambling profile. The design of this type of structure in the Chicago area is in accordance with the Uniform Building Code and is invariably governed by wind rather than seismic loads.

Notwithstanding the low earthquake risk for the ANL site, certain facilities have been conservatively designed when damage induced by earthquakegenerated forces might, even under farfetched assumptions, result in the release of hazardous materials. Since historic earthquakes at the. ANL site are estimated to have been no greater than MM $V$ in intensity, it is reasonable to conclude that the earthquake hazard at the ANL site presents, at most, a minor economic risk but no substantive risk to the environment.

\subsection{Tornadoes}

of all the accidents considered in this section, only the occurrence of a damaging tornado can be considered a realistic threat to the integrity of facilities that contain potentially harmful materials, hereafter referred to as Vital Facilities, or. VFs. In this section, the following subjects are treated in detail: the ANL emergency preparedness system to cope with a tornado threat; a general description of VFs, with special emphas is on tornado resistance; the results of a windspeed risk analysis performed for an area of 
Illinois that includes ANL; a discussion of the ANL tornado dispersion model used to determine offsite concentrations; and finally, a probabilistic treatment of the release of material from VFs as a direct result of a tornado strike at $\mathrm{ANL}$, with the resultant offsite doses.

Detailed inventories of potentially hazardous materials were compiled for each major site location. These inventories were reviewed to determine which materials, if accidentally released, would be of most concern to the general population. As might have been expected, the vast majority of the materials was of a conventional nature, e.g., flammable solvents, inert gases, and chemical reagents. Moreover, the amounts of these materials in use at any time were generally small laboratory quantities; the risk associated with their accidental release, though not quantified, was judged to be insignificant by comparison with that of other materials. In particular, it was considered that, qualitatively at least, the greatest potential threat to the offsite environment were posed by the large quantities of chlorine on hand for water and sewage treatment and the plutonium used by several onsite organizations in various forms and quantities. For the purpose of analysis of the specific tornado-induced release, the focus was on plutonium; a finding that the consequences are acceptable is considered prima facie evidence that tornadodispersion of other materials need not be considered further in this assessment.

\section{Tornado Emergency Preparedness}

ANL has a comprehensive emergency plan that defines the responsibilities of all emergency organizations and personnel. The plan provides guidance to help ensure an appropriate response to emergencies. The principal concerns of the plan are the protection of employees, visitors, and the general public from injury and death, and the minimization of property damage from unexpected events.

In addition to defining specific emergency responsibilities, the plan outlines procedures for coping with emergency situations that could affect the entire site or more than one of the facilities. As part of the overall emergency preparedness program, 38 individual facility emergency organizations have written plans and procedures for handling local incidents.

Any onsite incident that may affect persons and property offsite is immediately brought to the attention of DOE which coordinates actions by appropriate municipal, county, and state organizations. Accidents that occur adjacent to the site (e.g., traffic accidents) often are handled by the cooperative efforts of ANL and local governmental units.

One type of incident that can realistically affect the ANL site and adjacent areas is a severe storm. A tornado is the type of storm of most concern in view of the large potential for damage and personal injury. In a period of 102 years, there have been nine recorded tornadoes within a 16-km radius of the ANL site. In 1976 and 1978, tornadoes caused. some minor damage on the site but there were no deaths or injuries.

A considerable amount of planning has been done over the last five years in an effort to provide earlier and more accurate information to site personnel regarding the approach of severe windstorms. The objectives of the notifications are to permit personnel to postpone potentially hazardous operations, to 
take specific actions designed to limit potential damage, to put hazardous materials into the most storm-resistant mode possible and, most importantly, to provide adequate warning time to all onsite personnel so that tornado shelters may be utilized.

Personnel in all facilities that have the potential for release of hazardous materials are notified by the ANL Emergency Operator of all approaching storms with possibly damaging winds. In addition, all emergency response groups are notified.

\section{Plutonium-Use Facility Characteristics}

At ANL, large quantities (e.g., kilograms) of plutonium in use or in storage are contained within structures that, for all practical purposes, can be described as "tornado-proof". These structures include: the plutonium storage vaults of Bldgs. 316 and 350 , which were modified to especially accommodate the forces associated with large tornadoes (see Section 2.1.4.10); the many reinforced concrete cells housing $Z P R$ operations, irradiated reactor fuel examination facilities, etc., which, though not specifically designed for tornado resistance, are almost certain to survive a tornado strike with minimal damage; $*$ and below-grade storage rooms located in interior areas. In those few cases where the room itself might be considered vulnerable to tornado damage, the plutonium is usually stored in massive shielded pots, security safes, etc., all of which are expected to retain their integrity in the face of severe building damage.

Over a period of more than five years, continuing reviews of ANL plutonium operations have resulted in a strengthening of facilities, procedures, and training to cope with the occurrence of damaging tornadoes (see Section 3.4.3.5.3). Safety of ANL plutonium operations is reasonably ensured in all facilities that might not withstand large tornado-induced forces. The procedures in effect for the Bldg. 310 Experiment Assembly Facility (see Section 2.1.4.5) provide a typical example of the precautions employed in handling plutonium. In this facility, since only unirradiated fuel encapsulated in leak-tight stainless steel cladding is involved, the risk of tornado dispersal of plutonium offsite is minimal. Even if the cladding were damaged in such an event, the fuel form (i.e., sintered pellets) would mitigate against all but a very trivial dispersal. Nevertheless, containment facilities are provided to further reduce that risk. Specifically, fuel elements not in process are secured in a containment mode; they are stored either in a sealed DOT-licensed shipping cask or in wall-mounted storage trays with locked covers. In addition, a test train may be secured in a special protective pipe section that is bolted to a table that, in turn, is bolted to the floor. All fuel is thus protected whenever the facility is unattended for extended periods of time. In addition, detailed procedures for dealing with emergencies in Bldg. 310 are in effect. Finally; two "tornado alert" drills are conducted annually to test the responses of all personnel in securing the plutonium in process.

\footnotetext{
"Reynolds (1970) has written, "It is interesting to note that neither the review of more than 500 tornado articles, nor the personal investigation of 12 tornado damage paths, has revealed structural damage to reinforced concrete buildings. Such buildings have survived within very severely damaged areas."
} 
As a result of both detailed engineering analyses and subjective judgment, it is concluded that significant quantities of plutonium in process, or otherwise not secured against tornado damage, are present only in Bldgs. 200, 205, 212 , and 350. In this section, significant means tens of milligrams or larger quantities. These buildings are constructed with reinforced concrete frames and masonry walls. Structural evaluations have been made, and in some cases modifications were effected to improve the tornado resistance of VFs located within them. A listing of the VFs and the estimated windspeed required to breach them are given in Table 3.14.

Table 3.14. Vital Facilities and Windspeed Damage Threshold

\begin{tabular}{lcl}
\hline Vital Facility & $\begin{array}{c}\text { Minimum Windspeed } \\
\text { for Damage } \\
(\mathrm{km} / \mathrm{h})\end{array}$ & $\begin{array}{c}\text { Weakest Structural } \\
\text { Component }\end{array}$ \\
\hline Bldg. 200, Wing M laboratories & 265 & Curtain wall \\
Bldg. 205, Wing G & 300 & Frame \\
Bldg. 212, Special Facility FDl2 & 255 & Frame \\
Bldg. 350, Plutonium areas & 168 & Curtain wall \\
\hline
\end{tabular}

The threshold windspeeds given in Table 3.14 are based on damage to the structure surrounding the plutonium operations. In some cases, VFs contain windows that would probably fail well before the structure. It is assumed that window failure does not lead to loss of plutonium containment; all plutonium operations are enclosed within at least one other containment barrier (e.g., glovebox). On the other hand, major structural damage can reasonably be expected to result in some loss of VF containment, except where the plutonium is stored in a secure safe-like holder. Since it is impossible to reliably predict tornado-induced containment failure modes within a VF, a damage threshold approach was adopted as a reasonable compromise between the expected zero loss of plutonium containment for minor building damage and substantial loss of containment for catastrophic structural failure, i.e., for windspeeds well in excess of the threshold value. In short, an unknown function of damage vs. windspeed has been replaced with a step function. The plutoniumrelease model used in this statement, therefore, assumes that the plutonium at risk in each of the VFs is released when the windspeed damage threshold given in Table 3.14 is exceeded; lesser windspeeds result in zero release. The VFs listed in Table 3.14 are described in some detail in Section 2.1.4.

\section{ANL Windspeed Risk Model}

A windspeed risk model, which is defined as the probability of windspeeds exceeding some threshold value in one year, was developed for the ANL site by consultants at Texas Tech University. The risk model accounts for the possibility of both tornado and extreme straight winds at the site. For any selected probability, the maximum horizontal windspeed resulting from tornadoes 
or extreme winds can be determined from the model. Conversely, given a certain windspeed threshold, the probability of exceeding that value can be determined. As discussed in Section 3.4.3.5.3, the estimation in this assessment of the results of plutonium dispersal by tornadoes relies on the latter usage of the model.

The windspeed risk model was developed from records of tornado and extreme wind occurrences that have taken place in the vicinity of the ANL site. The tornado records cover a $15-y r$ period whereas the extreme wind records are based on a 21 -yr period.

Details of the model development and evaluation are given in the summary report (Texas Tech. Univ. 1975). Included therein are a review of the meteorological conditions conducive to tornado formation as well as a discussion of the methodology development, local storm data, computational details for the ANL area, and various uncertainties associated with the model.

The main result of this work is the curve shown in Figure 3.3. The curve was obtained by summing the individual probability distributions of tornadoes and straight winds. The use of Figure 3.3 will be discussed below in the subsection on Consequences of Tornado Strike.

\section{Tornado Dispersion Model}

A conservative, yet simple model to predict the ground-level concentration of a material dispersed by a tornado is presented in this section. Downwind ground-level concentrations are predicted by a multilevel application of the Gaussian "puff" dispersion model as described by Turner (1970). The material of interest is assumed to be entrained in the tornado vortex. The vortex then dissipates, leaving a volume source to be dispersed by the straight-line winds following the tornado. These post-tornadic winds are assumed to have a speed of $10 \mathrm{~m} / \mathrm{s}$. The entrained material travels with the winds, dispersing as time passes. All entrained material remains below the cloud base. For conservatism, puff depletion during transport--e.g., by washout or gravitational settling--is ignored.

To maximize the predicted offsite concentrations, the volume source is dispersed from the site boundary. Half of the material is entrained in the puff between 250 and $750 \mathrm{~m}$, with $25 \%$ below $250 \mathrm{~m}$ and $25 \%$ between $750 \mathrm{~m}$ and the cloud base, assumed to be at $1500 \mathrm{~m}$. Release points are assumed to be at the center of each level. Atmospheric conditions following the tornado are assumed to be unstable. The ground-level concentrations are given by the equation (Turner 1970):

$$
x(x, y, H)=\frac{2 Q(2 \Pi)-3 / 2}{\sigma_{x} \sigma_{y} \sigma_{z}} \exp \left\{-1 / 2\left[\left(\frac{x-u t}{\sigma_{x}}\right)^{2}+\left(\frac{y}{\sigma_{y}}\right)^{2}+\left(\frac{H}{\sigma_{z}}\right)^{2}\right]\right\}
$$




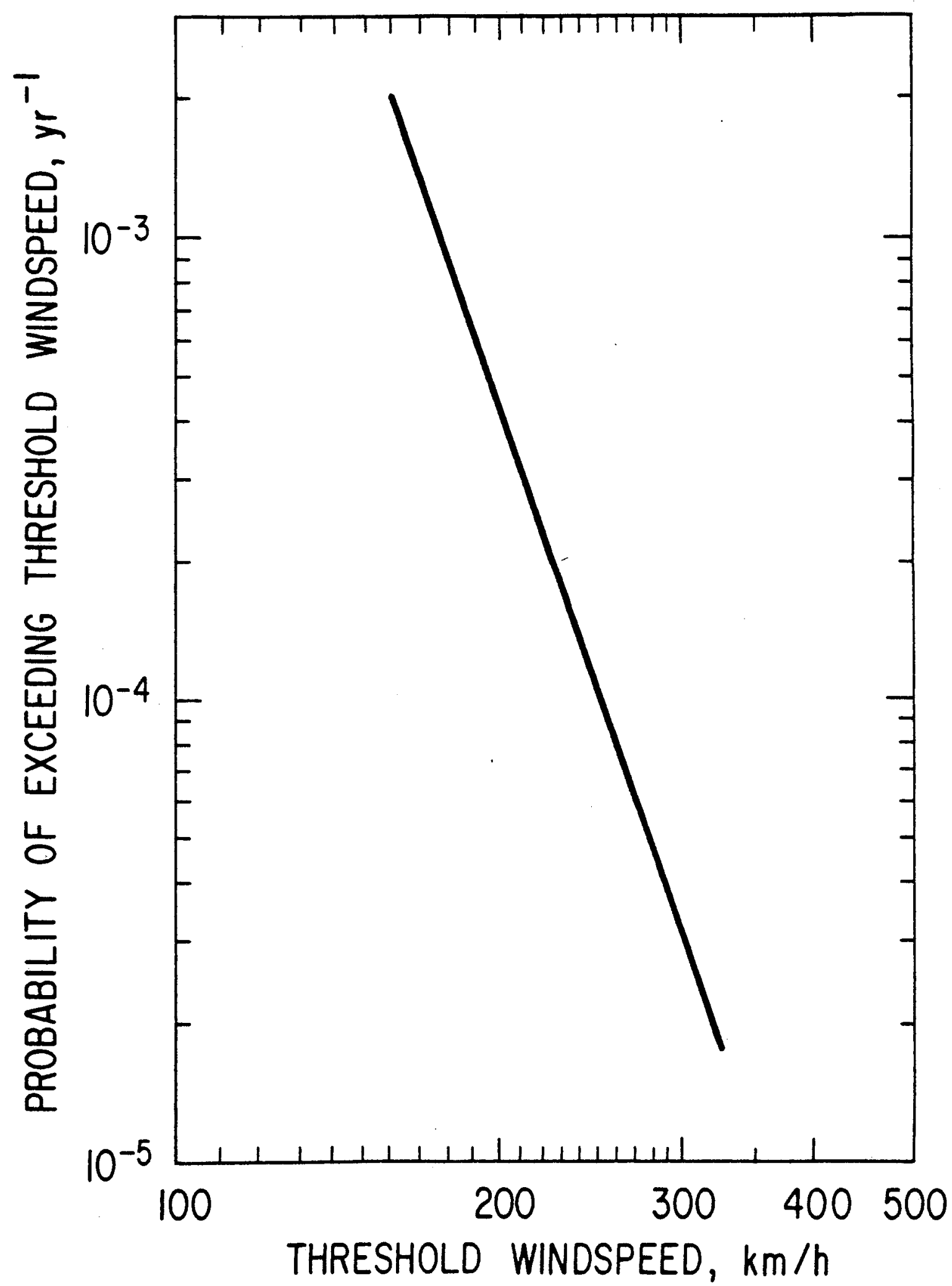

Figure 3.3. ANL Windspeed Risk Curve. 
where:

$$
\begin{aligned}
(\mathrm{x}, \mathrm{y}, \mathrm{H}) & =\text { concentration at } \mathrm{x}, \mathrm{y} \text { due to a release from height } \mathrm{H}, \mathrm{m}-\mathbf{3} \\
\mathrm{Q} & =\text { total release } \\
\mathrm{x} & =\text { downwind distance, } \mathrm{m} \\
\mathrm{y} & =\text { crosswind distance, } \mathrm{m} \\
z & =\text { vertical distance, } \mathrm{m} \\
\sigma_{\mathrm{x}} & =\text { dispersion coefficient in } \mathrm{x} \text { direction, } \mathrm{m} \\
\sigma_{\mathrm{y}} & =\text { dispersion coefficient in } \mathrm{y} \text { direction, } \mathrm{m} \\
\sigma_{z} & =\text { dispersion coefficient in } z \text { direction, } \mathrm{m} \\
\mathrm{u} & =\text { horizontal wind speed, } \mathrm{m} / \mathrm{s} \\
\mathrm{H} & =\text { effective height of release, m }
\end{aligned}
$$

The maximum concentration is found by simplifying Equation 3-1 to

$$
X(x, O, H)=\frac{2 Q(2 \Pi)-3 / 2}{\sigma_{x} \sigma_{y} \sigma_{z}} \exp \left[-1 / 2 \frac{H^{2}}{\left(\sigma_{z}\right.}{ }^{2}\right]
$$

Therefore, Equation $3-2$ is used to calculate the concentration on the ground at the puff centerline, due to a release occurring $\mathrm{H} \mathrm{m}$ above the ground. In this case, the concentrations are calculated for each of the three release heights (i.e., 125, 500, and $1125 \mathrm{~m}$ ) and then summed. The values of the os are taken from Turner and extrapolated linearly on $10 \mathrm{~g}-10 \mathrm{~g}$ paper. Analytically, they can be represented as follows:

$$
\begin{aligned}
& \sigma_{x}=\sigma_{y}=0.1432 x^{0.922} \\
& \sigma_{z}=0.5249 x^{0.728}
\end{aligned}
$$

Since the lung is an integrator, the integrated dose is simply the product of average concentration during exposure and exposure time. The pollutant puff is assumed to begin at one-tenth maximum concentration and to end at maximum concentration. The puff width between these limiting concentrations derives from consideration of the Gaussian distribution, and is

$$
x_{w}=2.146 \sigma_{x}
$$

where:

$$
\begin{aligned}
& x_{w}= \text { puff width from point of maximum concentration to point } \\
& \text { of one-tenth maximum concentration, } m
\end{aligned}
$$


The exposure time is calculated from

$$
t=\frac{x}{u}
$$

where:

$$
t=t \text { ime for puff to travel distance } x_{w}, s
$$

The results of these calculations are given in Table 3.15. Also included is the total integrated exposure, which is simply the product of the average concentration and exposure time. It can be fairly stated that the results are extremely conservative. For example, in an actual tornadic strike, some material (especially heavy powders) would be thrown a short distance by centrifugal force, removing a part of the source from downwind dispersion. Also, some material would undoubtedly reach the parent cloud, where dilution rates are very high. The values in Table 3.15 , therefore, represent an upper bound on concentrations resulting from such an event.

Table 3.15. Ground-Level Concentrations Following Tornado

\begin{tabular}{|c|c|c|c|}
\hline $\begin{array}{l}\text { Distance } \\
\text { Downwind } \\
\quad(\mathrm{km})\end{array}$ & $\begin{array}{c}\text { Average } \\
\text { Concentration } \\
\left(\mathrm{m}^{-3}\right)\end{array}$ & $\begin{array}{c}\text { Exposure } \\
\text { Time } \\
\text { (s) }\end{array}$ & $\begin{array}{c}\text { Total Integrated } \\
\text { Exposure } \\
\left(\mathrm{s} / \mathrm{m}^{3}\right)\end{array}$ \\
\hline 0.8 & $9.96 \times 10-9$ & 30 & $3.0 \times 10-7$ \\
\hline 2.4 & $2.41 \times 10-9$ & 82 & $2.0 \times 10-7$ \\
\hline 4.0 & $8.91 \times 10-10$ & 128 & $1.1 \times 10-7$ \\
\hline 5.6 & $4.64 \times 10-10$ & 176 & $8.2 \times 10.8$ \\
\hline 7.2 & $3.14 \times 10-10$ & 218 & $6.8 \times 10-8$ \\
\hline 12 & $1.11 \times 10-10$ & 362 & $4.0 \times 10-8$ \\
\hline 24 & $2.28 \times 10^{-11}$ & 686 & $1.6 \times 10-8$ \\
\hline 40 & $9.41 \times 10-12$ & 1112 & $1.0 \times 10-8$ \\
\hline 56 & $3.46 \times 10^{-12}$ & 1502 & $5.2 \times 10-9$ \\
\hline 72 & $1.89 \times 10^{-12}$ & 1888 & $3.6 \times 10-9$ \\
\hline
\end{tabular}
Dispersion for a Release of One Unit of Material

${ }^{a}$ Distance corresponds to midpoint of each sector radius given in Table 2.3. 


\section{Consequences of Tornado Strike}

The preceding sections have outlined the general approach taken in this statement to evaluate the consequences of a severe tornado strike on the ANL site, in particular with regard to the dispersion of plutonium in the atmosphere following a breach of containment attributable to high winds. In this section, that approach combined with the information in Appendix $B$ is used to calculate individual and population doses resulting from such an event.

The following is a brief outline of the methodology employed in this analysis:

(a) The release rate of plutonium from any of the four VFs is calculated by multiplying the amount of material at risk, i.e., likely to be released if the VF collapsed, by the probability that the threshold windspeed for that VF is exceeded. The result is given in $\mu \mathrm{Ci} / \mathrm{yr}$.

(b) The amount released from (a) is multiplied by 50 to get the "puff" equivalent of a 50-yr continuous release.

(c) The release from (b) is multiplied by the total integrated exposure incurred during the passage of the puff from Table 3.15; the total exposure has units of $\mu \mathrm{Ci}_{\mathrm{i}}-\mathrm{s} / \mathrm{m}^{3}$.

(d) The amount of material inhaled is calculated from Equation B-1 of Appendix B.

(e) The dose commitment is calculated from Equation B-2.

(f) The calculated dose commitment is corrected to the continuousrelease value.

Table 3.16 gives the probability of exceeding the threshold windspeed for each of the four VFs listed in Table 3.14. Table 3.17 lists the material at risk in each VF and the results of the multiplication described in (a).

Table 3.16. Probability of Exceeding Threshold Windspeed

\begin{tabular}{lcr}
\hline Building & $\begin{array}{c}\text { Threshold } \\
\text { Windspeed } \\
(\mathrm{km} / \mathrm{h})\end{array}$ & $\begin{array}{c}\text { Probability } \\
\left(\mathrm{yr}^{-1}\right)\end{array}$ \\
\hline 200 & 265 & $7 \times 10-5$ \\
205 & 300 & $3 \times 10-5$ \\
212 & 255 & $9 \times 10-5$ \\
350 & 168 & $1.4 \times 10-3$ \\
\hline
\end{tabular}

${ }^{a}$ Probability of exceeding threshold windspeed (from Figure 3.3). 
Table 3.17. Material at Risk During Tornado Strike

\begin{tabular}{|c|c|c|c|c|c|c|c|c|c|c|c|}
\hline \multirow[b]{3}{*}{ Nuclide } & \multicolumn{9}{|c|}{ Building } & & \multirow{3}{*}{$\frac{\text { Total }}{M R R}$} \\
\hline & \multicolumn{2}{|c|}{200} & \multicolumn{2}{|c|}{205} & \multicolumn{2}{|c|}{212} & \multicolumn{2}{|c|}{350 (NBL) } & \multicolumn{2}{|c|}{350 (ANL) } & \\
\hline & $\operatorname{MAR}^{a}$ & $\mathrm{MRR}^{\mathbf{b}}$ & MAR & MRR & MAR & MRR & $\operatorname{MAR}^{c}$ & MRR & MAR & MRR & \\
\hline \multicolumn{12}{|l|}{ Plutonium-238 } \\
\hline Soluble & 0.05 & 3.5 & - & - & - & - & 1. & 1,400 & - & - & 1,404 \\
\hline Insoluble & - & - & - & - & - & - & 1. & 1,400 & - & - & 1,400 \\
\hline \multicolumn{12}{|c|}{ Plutonium-239 } \\
\hline Soluble & 0.7 & 49. & - & - & - & - & 29 & 40,600 & - & - & 40,649 \\
\hline Insoluble & - & - & 0.032 & 1.0 & 1.1 & 99. & 29. & 40,600 & 26 & 36,400 & 77,100 \\
\hline \multicolumn{12}{|c|}{ Plutonium-240 } \\
\hline Soluble & 0.34 & 24 & - & - & - & - & 11.5 & 16,100 & - & - & 16,124 \\
\hline Insoluble & - & - & - & - & - & - & 11.5 & 16,100 & - & - & 16,100 \\
\hline \multicolumn{12}{|c|}{ Plutonium-24l } \\
\hline Soluble & 0.02 & 1.4 & - & - & - & - & 6. & 8,400 & - & - & 8,402 \\
\hline Insoluble & - & - & - & - & - & - & 6. & 8,400 & - & - & 8,400 \\
\hline \multicolumn{12}{|c|}{ Plutonium-242 } \\
\hline Soluble & 0.4 & 28 & - & - & - & - & 2.5 & 3,500 & - & - & 3,528 \\
\hline Insoluble & - & - & - & - & - & - & 2.5 & 3,500 & - & - & 3,500 \\
\hline \multicolumn{12}{|c|}{ Americium-24l } \\
\hline Soluble & 0.3 & 21 & - & - & - & - & - & - & - & - & 21 . \\
\hline Insoluble & - & - & - & - & - & - & - & - & 0.3 & 42. & 42. \\
\hline
\end{tabular}

${ }^{a_{M A R}}=$ material at risk, $\mathrm{g}$. Dose calculations require conversion to Ci.

$b_{M R R}=$ material release rate $=$ MAR $\times$ probability from Table $3.16, \mu g / y r$.

Either the Soluble or Insoluble values apply at any time. 
The material at risk was determined by a careful evaluation of each VF by knowledgeable personnel. In all cases, however, the results are believed to be conservative upper bounds.

The subsequent calculations are straightforward. The dose results are given in Table 3.18 for two cases, $S$ and $I$. In Case $S$, all the plutonium in NBL is assumed to be soluble; in Case I, that material is assumed to be insoluble. Also given in that table are the corresponding population doses. These were calculated by multiplying the individual doses at a given sector radius by the highest population in any sector at that same radius (as given in Table 2.3). This procedure clearly results in an upper limit on the population dose.

\subsubsection{Transportation Accidents}

Radioactive materials are shipped to and from ANL in packages that meet all applicable federal and international standards and regulations. All such shipments are the responsibility of SPM. As a DOE-owned laboratory, ANL is obligated to follow the packaging requirements promulgated by DOE (U.S. Energy Res. Dev. Admin. 1976). These requirements consider the type and quantity of material being shipped. They also specify severe abnormal environmental conditions--e.g., fire, immersion in water--that the package must survive with only limited damage and essentially no release of radioactive material. Since these abnormal conditions represent hypothetical (i.e., low-probability) events and since most shipments consist of materials with low activity levels, the risk to the general public from transportation accidents is so small that a more detailed analysis is not required for this assessment.

Large quantities of nonradioactive materials and supplies are routinely shipped to the ANL site by truck. Some of the more potentially hazardous substances include liquid gases such as chlorine, oxygen, and nitrogen and an array of laboratory chemicals including strong mineral acids and toxic or carcinogenic organic chemicals. These shipments are made by commercial vendors and carriers, in accordance with DOT guidelines and requirements (49 CFR Parts 139 and 171 through 179) and other applicable federal and state statutes. An evaluation of the consequences of potential transportation accidents is beyond the scope of this EA.

\subsubsection{Summary of Accidents}

The accident analyses in Section 3.4 .3 consisted of developing scenarios for classes of accidents and calculating the consequences beyond the site boundary of specific accidents in each class. In all cases, wherever possible, realistic assumptions were used in keeping with the spirit of NRC Regulatory Guide 4.2 (U.S. Nucl. Reg. Comm. 1976). The significant results of each accident calculation are summarized in Table 3.19 .

In all cases where radionuclides are released, the calculated individual lifetime organ dose commitments are substantially less than those due to natural background radiation. For example, the largest value, $200 \mathrm{mrem}$, averages out to $4 \mathrm{mrem} / \mathrm{yr}(200 / 50)$, only about $4 \%$ of the whole-body dose attributable to naturally occurring radiation. The next largest dose commitment, 1.2 mrem, is only $0.02 \%$ of that value. 
Table 3.18. Plutonium Dose Commitment Following Tornado Strike

\begin{tabular}{|c|c|c|c|c|c|c|c|c|}
\hline \multirow{2}{*}{$\begin{array}{l}\text { Distance } \\
\text { from Site } \\
\quad(\mathrm{km})\end{array}$} & \multicolumn{2}{|c|}{ Lung } & \multicolumn{2}{|c|}{ Bone } & \multicolumn{2}{|c|}{ Liver } & \multicolumn{2}{|c|}{ GI } \\
\hline & $\mathbf{s}^{\mathbf{b}}$ & $I^{b}$ & $\mathbf{S}$ & I & $\mathbf{S}$ & I & $\mathbf{S}$ & I \\
\hline \multirow[t]{2}{*}{$0-1.6$} & $1.5 \mathrm{E}-2$ & 0.02 & 0.60 & 0.30 & 0.066 & 0.034 & $6.2 \mathrm{E}-6$ & $7.6 E-6$ \\
\hline & 0 & 0 & 0 & 0 & 0 & 0 & 0 & 0 \\
\hline \multirow[t]{2}{*}{$1.6-3.2$} & $1.0 \mathrm{E}-3$ & 1. $3 E-2$ & 0.40 & 0.20 & 0.044 & 0.022 & $4.2 \mathrm{E}-6$ & $5.2 \mathrm{E}-6$ \\
\hline & 1.76 & 23.2 & 692. & 346. & 76. & 38 . & 0.008 & 0.010 \\
\hline \multirow[t]{2}{*}{$3.2-4.8$} & $5.8 E-4$ & $7.6 \mathrm{E}-3$ & 0.22 & 0.110 & 0.024 & 0.012 & $2.4 E-6$ & $3.0 \mathrm{E}-6$ \\
\hline & 2.18 & 28.6 & 824. & 412. & 90. & 45 & 0.008 & 0.010 \\
\hline \multirow[t]{2}{*}{$4.8-6.4$} & $4.4 E-4$ & $5.8 E-3$ & 0.152 & 0.076 & 0.0174 & 0.0088 & $1.7 \mathrm{E}-6$ & $2.0 \mathrm{E}-6$ \\
\hline & 3.48 & 45.8 & 1202. & 600 & 138 & 68.8 & 0.014 & 0.018 \\
\hline \multirow[t]{2}{*}{$6.4-8.0$} & $3.4 E-4$ & $4.4 E-3$ & 0.136 & 0.068 & 0.0144 & 0.0072 & $1.4 \mathrm{E}-6$ & 1. $7 E-6$ \\
\hline & 3.02 & 39.8 & 1204. & 602 & 128 & 63.8 & 0.012 & 0.014 \\
\hline \multirow[t]{2}{*}{$8.0-16$} & $2.0 \mathrm{E}-4$ & $2.6 \mathrm{E}-3$ & 0.080 & 0.040 & 0.0086 & 0.0044 & $8.4 E-7$ & $1.0 \mathrm{E}-6$ \\
\hline & 15.5 & 204. & 6200 & 3100. & 666 & 334. & 0.066 & 0.082 \\
\hline \multirow[t]{2}{*}{$16-32$} & $8.0 \mathrm{E}-5$ & $1.0 \mathrm{E}-3$ & 0.032 & 0.016 & 0.0034 & 0.0018 & $3.2 E-7$ & $4.0 \mathrm{E}-7$ \\
\hline & 54.8 & 720 & 21888 & 10944. & 2326 & 1162. & 0.218 & 0.268 \\
\hline \multirow[t]{2}{*}{$32-48$} & $5.4 \mathrm{E}-5$ & $7.2 \mathrm{E}-4$ & 0.020 & 0.010 & 0.0024 & 0.0012 & $2.2 \mathrm{E}-7$ & $2.8 \mathrm{E}-7$ \\
\hline & 33.8 & 444 & 12520 & 6260 & 1502 & 752 & 0.138 & 0.170 \\
\hline \multirow[t]{2}{*}{$48-64$} & $2.6 \mathrm{E}-5$ & $3.4 \mathrm{E}-4$ & 0.010 & 0.006 & 0.0012 & 0.0006 & $1.1 E-7$ & $1.3 \mathrm{E}-7$ \\
\hline & 8.0 & 105 & 3080 & 1540 & 370 & 185 & 0.032 & 0.040 \\
\hline \multirow[t]{2}{*}{$64-80$} & $1.8 E-5$ & $2.4 \mathrm{E}-4$ & 0.0070 & 0.004 & 0.0008 & 0.0004 & $7.2 \mathrm{E}-8$ & $8.8 \mathrm{E}-8$ \\
\hline & 3.48 & 45.8 & 1352 & 676 & 154 & 77.2 & 0.014 & 0.018 \\
\hline \multicolumn{9}{|l|}{ Total } \\
\hline \multicolumn{9}{|l|}{ Population } \\
\hline Dose & 126. & 1656 & 48,962 . & 24,480 & 5450. & 2726 & 0.52 & 0.64 \\
\hline
\end{tabular}

${ }^{a}$ Top number of each pair is individual 50-yr dose commitment (rem); bottom number is population dose commitment (person-rem).

${ }^{b} S=N B L$ plutonium in soluble form; $I=N B L$ plutonium in insoluble form. 
Table 3.19. Summary of Significant Accident Analysis Results

\begin{tabular}{|c|c|c|c|}
\hline Accident & $\begin{array}{l}\text { Material } \\
\text { Released to } \\
\text { Environment }\end{array}$ & $\begin{array}{l}\text { Critical } \\
\text { Organ or } \\
\text { Region }\end{array}$ & $\begin{array}{l}\text { Maximum Individual } \\
\text { Lifetime Dose } \\
\text { Commitment (mrem) }\end{array}$ \\
\hline NBL glovebox explosion & Plutonium & Bone & 1.2 \\
\hline MSD glovebox explosion & Plutonium & Bone & $3 \times 10-4$ \\
\hline Uranium fire & Uranium & Lung & $3.4 \times 10.5$ \\
\hline Plutonium fire & Plutonium & Bone & $1.7 \times 10^{-3}$ \\
\hline Accidental criticality & None & $N A^{a}$ & $\mathrm{NA}$ \\
\hline Nonradioactive spill & Chlorine & $\mathrm{N}-\mathrm{P}, \mathrm{T}-\mathrm{B}, \mathrm{P}^{\mathrm{b}}$ & $0.5^{c}$ \\
\hline Radioactive spill & Cobalt -60 & Lung & 0.06 \\
\hline Flood & None & NA & $\mathrm{NA}$ \\
\hline Earthquake & None & NA & NA \\
\hline Tornado & Plutonium & Bone & $200^{d}$ \\
\hline Transportation & None & NA & NA \\
\hline
\end{tabular}

In order to put the population dose commitment in perspective, consider the highest such value, approximately 49,500 person-rem for the bone dose in Case S, Table 3.18. Over a 50-yr period, the exposed population ( 1.91 million) would receive a whole-body dose from natural background radiation of 8.8 million rem $(0.092 \times 50 \times 1.91$ million $)$. Since current exposure standards imply a permissible ratio of bone to whole-body dose of six (Int. Comm. Radiol. Prot. 1959), it can be inferred that an "acceptable equivalent natural background" bone dose is 53 million rem $(6 \times 8.8$ million). This latter value is more than 1000 times the calculated value for the tornado release.

A second way of relating the calculated plutonium dose to everyday risk is to consider naturally occurring radiation that exposes individuals internally. For example, in the United States, the estimated average annual dose per person to the bone marrow is $24 \mathrm{mrem}$ (U.S. Environ. Prot. Agency 1977). Over a 50-yr period, the total bone marrow dose commitment is therefore 2.3 million rem $(0.024 \times 50 \times 1.91$ million $)$ or almost 50 times the calculated bone dose commitment for the tornado release.

Using either of the above comparisons, it is clear that the population exposures due to plutonium dispersed by a tornado are small compared with the exposures resulting from natural background radiation. 


\subsection{CONTINUING EFFECTS OF PAST OPERATIONS}

The continuing environmental impacts resulting from discontinued operations are discussed in this section.

\subsubsection{Plutonium Glovebox Storage}

Building 350 was constructed to house a fabrication facility that became operational in 1959; it was used extensively during its fifteen-year life for developing methods of alloying, casting, machining, cladding, and assembling reactor fuel elements containing plutonium. To accomplish its goals, the facility contained a variety of equipment, from small-scale laboratory instruments to full-scale rolling mills, machine tools, hydraulic presses, and a variety of furnaces. This equipment was enclosed within a modular system of specially designed gloveboxes. Specific types of equipment, such as machine tools and vacuum furnaces, were assembled into individual glovebox lines, and the glovebox lines were interconnected through a central conveyor system approximately $30-\mathrm{m}$ long.

During its lifetime, the facility throughput amounted to hundreds of kilograms of plutonium-239 in metallic and ceramic form, as well as other fissile materials. However, in 1973, a portion of the work and the associated hardware were transferred to the MSD Special Facility FD12, described in Section 2.1.4.7. The remaining 24 gloveboxes were declared surplus, and plans were developed to dispose of them. Currently, the gloveboxes are being dismantled and disposed according to routine ANL procedures for handling rad-wastes. The decommissioning and disposal operations will be completed by September 1982 .

The major environmental hazard of the current situation, i.e., the temporary storage and dismantling of plutonium-contaminated gloveboxes in Bldg. 350, is the potential release of plutonium dust in the event of a tornado strike that would cause major structural damage to the building. This impact is discussed in detail in Section 3.4.3.5.3. Other less serious potential impacts, e.g., the accidental release of small amounts of plutonium from the facility during decontamination activities, are considered remote.

\subsubsection{Radionuclides in Offsite Soil}

Prior to 1973, ecology studies were performed in certain onsite areas that were subsequently transferred to the DuPage County Forest Preserve District and that currently lie outside the site boundary fence. In these studies, radioactive tracer elements were injected into the soil in three small areas, the largest of which was $7.4 \mathrm{~m}^{2}$. The isotopes and respective amounts used are given in Table 3.20 .

Subsequent soil analyses (Sedlet and Duffy 1972) showed that the relatively long-lived zinc and silver nuclides did not contribute measurably to the total activities of those soil samples. The latter, in turn, were commensurate with those of samples taken far from the site and attributable to natural and fallout radiation. The short-lived mercury and cadmium nuclides were not detected.

Hydrogen-3 concentrations in the groundwater were from 10 to 1000 times as high as those in normal water. After about $30-45 \mathrm{~cm}$ of soil was removed, 
Table 3.20. Radioisotopes Used in

Ecology Experiments

\begin{tabular}{lc}
\hline Nuclide & $\begin{array}{c}\text { Total Amount } \\
\text { into Soil }\end{array}$ \\
\hline Cadmium-115m
\end{tabular}

it was evident that the hydrogen-3 had penetrated deeper into the ground. However, since the total amount of hydrogen-3 injected was only $50 \mathrm{mCi}$, the residual material in the ground is of no significance.

\subsubsection{Suspect Waste Landfill}

From 1948 to 1968, ANL operated an onsite suspect waste landfill located just east of the waste storage area (Facility 317). Material buried in the landfill included uncontaminated items that had been closely associated with contaminated items, as well as suspect items that could not have their contamination status accurately determined.

A radiological survey was conducted in the area in 1971. Analyses of soil samples indicated that the concentrations were consistent with environmental fallout levels. Cobalt-60 was detected in one sample but the concentration was similar to that of nuclides arising from fallout.

\subsubsection{Effluent from Experimental Boiling Water Reactor}

ANL operated the Experimental Boiling Water Reactor (EBWR) from 1957 to 1967. Most of the radioactive emissions were short-lived and had no continuing environmental impact. Small amounts of fission and/or activation products, primarily cobalt-58 and cobalt-60, were routinely released in liquid effluents to Sawmill Creek through a building retention tank and the Laboratory holdup tanks. The concentrations of these isotopes were routinely measured and the results reported in the annual environmental monitoring reports of the period. Some of the longer-lived radioactive effluents still exist in the environment, but they constitute an undetectable addition to the local and worldwide inventory of radionuclides from weapon fallout.

\subsubsection{Contamination in Sewage Treatment Area}

Occasionally in the past, small portions of the sewage treatment area were used to hold radioactive liquid effluents prior to treatment and discharge. The bottoms of these retention ponds accumulated some radionuclides. Most of this material was excavated from the ponds, but some radionuclides that migrated more deeply into the soil may remain. 
A small amount of surface contamination was located in the general area of the settling ponds. A sampling program was conducted to determine the extent of the problem. The results indicated that one isolated spot contained plutonium-239 at a concentration of about $2 \mathrm{pCi} / \mathrm{g}$. No other radionuclides existed at concentrations above natural or fallout levels. Although the plutonium concentration is insignificant, an effort is underway to evaluate the situation completely and make recommendations, if necessary, for further action.

\subsubsection{Unused Excavation}

A new research reactor was planned for a site located about $180 \mathrm{~m}$ northwest of the CP-5 reactor. Excavation for the containment building was completed and the concrete base mat poured prior to the termination of the project in April 1968. The excavation was fenced and eventually filled with water; it now contains fish.

In 1978, hydrogen-3 was present in the water at an average concentration of approximately $12 \mathrm{nCi} / \mathrm{L}$, about one-half of the permissible drinking water level (U.S. Environ. Prot. Agency 1976). Measurements taken during 1980 (following shutdown of CP-5 in 1979), indicate that levels had dropped to about $8.5 \mathrm{nCi} / \mathrm{L}$. The source of this nuclide was most likely the airborne tritiated water effluent from the CP-5 reactor. The total amount of hydrogen-3 in the water, based on an estimate of the volume of the excavation, is about $0.16 \mathrm{Ci}$, or about $0.04 \%$ of the $\mathrm{CP}-5$ annual release. The pond does not constitute an environmental hazard.

\subsubsection{Disposal of Reactive Chemicals}

Until 1971, small quantities (kilograms) of reactive chemicals, e.g., sodium and potassium, were occasionally disposed of by dumping them into a small onsite pond where they reacted with water. There is no direct flow of water into or out of the pond, which is now outside the site fence. It is unlikely that there is any significant residual effect of the dumping activities. Such chemicals are now disposed by reacting them with water in one of the concrete vaults in Facility 317.

\subsubsection{Disposal of Liquid Wastes in Landfill}

From 1969 through 1978, substantial quantities (i.e., over 50,000 L) of nonradioactive liquid wastes were disposed onsite by dumping them into an open "French drain" located in the ANL sanitary landfill. These liquid wastes consisted mostly of waste oil and various organic chemicals, but also included about $400 \mathrm{~L}$ of transformer coolant (PCBs) and significant quantities of inorganic chemicals such as ferric chloride.

Due to the impermeable nature of the clay soil beneath the landfill and the compacted clay cover material, it is unlikely that significant movement of the chemicals has occurred. Additionally, because the chemicals were dumped onto stones in the "French drain", it is possible that large quantities of the more volatile organic chemicals quickly evaporated.

ANL has recently instituted a systematic monitoring program designed to detect surface and subsurface leaching of potentially hazardous liquids from 
the landfill. The monitoring program basically consists of installation of six shallow groundwater wells around the perimeter of the landfill, periodic analysis of water samples from these wells for pertinent chemical parameters, and visual inspection of the landfill perimeter for surface leachates. ANL is prepared to initiate mitigative measures to prevent environmental contamination should the monitoring program detect significant leaching of hazardous liquids from the landfill. To date, no significant leachates have been observed.

\subsubsection{Decommissioning of ANL Research Reactors}

Three nuclear reactors operated at ANL for various research and development programs between 1954 and 1979 were shut down as the programs were completed.

ANL's Experimental Boiling Water Reactor (EBWR) facility, located in Bldg. 331, was the first reactor in the western world designed and built solely for the purpose of conducting experiments on the generation of nuclear electric power for commercial purposes. This reactor was operated from 1956 to 1967 at up to $100,000 \mathrm{~kW}$ thermal, producing approximately $5000 \mathrm{~kW}$ of electric power.

The Juggernaut Reactor, Bldg. 335, was operated from 1962-1970, primarily as a source of neutrons for development and refinement of methods and techniques of neutron radiography. The reactor had a thermal power rating of $250 \mathrm{~kW}$ and was water-cooled and -moderated.

Chicago Pile-Five (CP-5), located in Bldg. 330 , was the principal nuclear reactor used for the production of neutrons for scientific research at ANL from 1954 to 1979. The reactor had a thermal power rating of $5000 \mathrm{~kW}$ and was water-cooled and -moderated.

At the time of shutdown, these three reactor facilities were placed in "dry-layup" status (i.e., rendered unreactive by removal of fuel and water moderator). This layup status represents a minimum level of decommissioning. The reactor facilities could be maintained in this environmentally safe status indefinitely or could be further decommissioned and decontaminated. ANL has conducted preliminary investigations relative to complete decommissioning of the three facilities, i.e., removal and disposal of all potentially hazardous radioactive materials (NUS Corp. 1979a, 1979b; Argonne Natl. Lab. 1981a). The reports conclude that complete removal and disposal of all radioactive materials in the three facilities could be safely accomplished with insignificant radiation exposure to the public and minimum exposure to the decommissioning work forces. It is anticipated that complete decommissioning will be undertaken when federal funds become available.

\subsubsection{Decommissioning of the ZGS}

The Zero Gradient Synchrotron (ZGS) complex was used for atomic particle acceleration related to high energy physics experiments. The ZGS complex consists of 40 separate buildings and many interrelated component systems. In 1978, ZGS closing activities began with shutdown of some component systems. Decommissioning activities have involved all buildings and approximately $50 \%$ of the total ZGS area. 
Activities to date have consisted mainly of dismantling and shipping reusable equipment to a total of 35 separate organizations (e.g., government research facilities and universities). Approximately 1700 truckloads of equipment valued at over $\$ 50$ million. have been shipped.

The primary potential for adverse environmental effects is related to decontamination, dismantling and shipping of radioactive equipment. It is estimated that up to $760 \mathrm{~m}^{3}$ of such low-level waste will be shipped offsite for approved burial. Additionally, approximately 26,000 L of PCB-containing liquids must be removed from the complex and prepared for later disposal. Current plans call for drumming of the liquids and storage within a diked enclosure onsite until such time as appropriate disposal options may be selected. Throughout the decommissioning, Health Physics personnel have been, and will continue to be, in the ZGS complex to provide radiological surveys of equipment, buildings, and storage areas, and to monitor the handling, movement, and storage of radioactive and hazardous wastes. It is expected that decommissioning will be completed in late 1982 .

\subsubsection{Impact of Onsite Fallow Deer}

The ANL population of European fallow deer (Dama d. dama) may have adverse impacts to the local environment both onsite and offsite. Because the deer population is currently growing, the future potential for impacts is apparent. At this time, the deer population onsite is in excess of 400 head. These deer have available approximately 400 to 500 ha of habitat serving both as forage and cover resources. The ANL site supports a herd density of almost twice that which well-managed forest in England generally is able to maintain (Chapman and Chapman 1975).

To date, several problems have arisen as the fallow deer herd has increased:

- Development of a conspicuous network of deerpaths in the meadowlands and woodlands of the ANL site.

- Increased erosion along streambanks due to frequent passage of deer.

- Damage to fencing by deer passage.

- Development of a conspicuous browse line in onsite woodlots.

- Unsightly deposits of deer feces in areas of human activity.

- Excessive browsing of managed plantings both onsite and offsite.

- Accidents between deer and motor vehicles

In addition, increasing population pressures may induce greater dispersal of fallow deer offsite. This could lead to greater damage to offsite properties, and dispersal could increase competition between the exotic fallow deer and native white-tailed deer.

ANL has minimized problems with the fallow deer population through implementation of a management plan (the updated plan is outlined in Appendix $C$ ). 
The basic strategy of the plan is to maintain the deer herd at an environmentally compatible population size (recently determined to be about 200 individuals) by periodically capturing appropriate numbers of does and shipping them offsite to responsible outlets (e.g., zoos) where escape to the wild can be prevented.

\subsection{ECONOMIC AND SOCIOCULTURAL IMPACTS}

\subsubsection{Economic Impacts}

Although ANL has only a small economic impact on the Chicago metropolitan area, it nevertheless does have an impact on the nearby surrounding communities. With a working force of about 4500 persons, ANL is one of the largest employers in DuPage County and one of the major employers in the state (U.S. Bur. Census 1981).

The total payroll of ANL is currently about $\$ 125$ million, compared with approximately $\$ 3.8$ billion for all of DuPage County and approximately $\$ 60$ billion for all of Illinois (1979) (U.S. Bur. Census 1981). Although employees commute to ANL from distances as great as $50 \mathrm{~km}$ and the payroll is very widespread, the economic impact on nearby villages is, nevertheless, significant. For example, Lemont, the closest village, had about 200 resident ANL employees out of a total population of 5200, and the ANL employees payroll was about $10 \%$ of the village's total personal income. Downers Grove, about $4 \mathrm{~km}$ distant, has the largest number of ANL employees (nearly 500) of any single incorporated area. The ANL employees are about $1 \%$ of the population and the payroll is about $4 \%$ of the personal income. In 1978, there were 10 or more Argonne employees residing in 59 cities or villages of the area, with a minimum annual payroll in any of these villages of over $\$ 140,000$.

In addition to the direct impact of payroll, ANL also purchases utilities, services, equipment, and supplies--much of this locally. The total amount spent for these purposes is about $\$ 80 \mathrm{million.}$ In addition to operating expenditures, various capital expenditures are made on an irregular basis for new buildings or large projects. The plant facilities existing in 1976 had an acquisition cost of about $\$ 170$ million.

\subsubsection{Sociocultural Impacts}

ANL has provided an employment center for a large number of highly trained individuals, many of whom are highly motivated to participate in the civic affairs and cultural life of their communities. As a result, there have been many ANL employees who have been leaders in school affairs, held local political offices, and participated in other civic activities. Others have been active in cultural activities, such as organizing concert series, and have participated in local musical and dramatic groups. Argonne personnel have taught in local and regional educational institutions, and conversely, many educators and students have attended courses and seminars at Argonne or participated in the Laboratory work. Over 1000 university faculty members and students take part in ANL short courses, conferences, and workshops each year. Also, industrial and government workers have been trained in new industrial techniques developed or studied at Argonne. 
On a less technical level, educational and civic groups are continually being taken on tours of ANL facilities. Several hundred tours per year are given, and many thousands of regional residents participate.

Outside of the ANL site, an educational program on environmental and energy affairs has been provided for a number of western Indian tribes impacted by coal and uranium mining in their areas. On the local level, ANL affirmative action programs have trained and encouraged students from disadvantaged groups to enter the technical fields where skilled people are needed.

\subsection{SPECIAL NUCLEAR MATERIALS SAFEGUARDS AND SECURITY}

It is ANL policy that nonnuclear and fundamental research programs not be constrained by the SNM safeguards measures required for protection of nuclear materials, and that the facilities with nonnuclear projects be kept accessible to the public within the limits of normal safety and plant protection requirements. An island concept of nuclear material safeguards and security is employed at ANL. The locations where nuclear material is used or stored are subject to a graded system of physical protection and accountability procedures, in compliance with DOE policies. Each facility containing SNM is under continuing study to assess the possible threat to SNM and to develop safeguards and security procedures and plans to counter those threats that are deemed credible.

Over the past several years, the requirements and regulations governing the facilities in which SNM can be used or stored have changed and are still in a state of revision. They now address hardening against terrorist attack, tornado and earthquake resistance, multiple security barriers designating "protected areas" around material access areas, barrier alarms, internal a larms, alarm appraisal systems, guard stations, doorway monitors, and personnel identification and access control systems.

DOE requires that each facility using or storing SNM have a site-specific safeguard and security plan approved by the cognizant DOE operations office. This plan describes systems used for security, material control, and accountability. DOE provides guidelines for development of a graded system based upon the quantity, composition, attractiveness for diversion, portability, and accountability of SNM. The security requirements categorized by fissile isotope quantity are shown in Table 3.21 .

ANL has recently completed a five-year Safeguards and Security Improvement Program (SSIP). The objective of this program was to meet new requirements for protection of SNM against natural events such as earthquakes or tornadoes, and to meet requirements for protection of Category I levels of SNM. Generally, this means that the SNM is to be within an alarmed material access area, which is in turn surrounded by an alarmed protected area. Four such areas were identified for upgrading and are now equipped with attack-resistant guard stations, a local alarm panel, a base radio station, and personnel, SNM, and metal detection equipment. Vaults have been reinforced for greater tornado and earthquake resistance. A hardened secondary security command station was installed. 
Table 3.21. Security Requirements for Special Nuclear Materials Facilities

\begin{tabular}{|c|c|c|}
\hline Category & Fissile Isotope (kg) & Features of SNM Security System \\
\hline I & $\begin{array}{ll}\text { Uranium-235 } & >5.0 \\
\text { Uranium-233 } & \\
\text { Plutonium } & >2.0\end{array}$ & $\begin{array}{l}\text { SNM used in "Material Access } \\
\text { Area" (MAA) which is within a } \\
\text { "Protected Area" (PA); two } \\
\text { barriers; intrusion alarmed; } \\
\text { Q clearance required of persons } \\
\text { working with SNM; access } \\
\text { controlled; hardened security } \\
\text { post; dual communications } \\
\text { capabilities; SNM and contra- } \\
\text { band searches; guard patrols } \\
\text { and available response force. }\end{array}$ \\
\hline II & $\begin{array}{l}1.0<\text { Uranium-235 }<5.0 \\
0.4<\left\{\begin{array}{l}\text { Uranium-233 } \\
\text { Plutonium }\end{array}<2.0\right.\end{array}$ & $\begin{array}{l}\text { SNM in PA; at least one sub- } \\
\text { stantial barrier; alarm systems; } \\
\text { access control; vehicle controls } \\
Q \text { clearance for persons working } \\
\text { with SNM; guard patrols and } \\
\text { response force; search for con- } \\
\text { traband and SNM. }\end{array}$ \\
\hline III & $\begin{array}{l}\text { Uranium-235 }<1.0 \\
\text { Uranium-233 } \\
\text { Plutonium }\end{array}<0.4$ & $\begin{array}{l}\text { Access limited to authorized } \\
\text { personnel; storage in locked } \\
\text { and alarmed containment when } \\
\text { not attended; personnel and } \\
\text { packages subject to search for } \\
\text { contraband; guard patrols when } \\
\text { area is not occupied. }\end{array}$ \\
\hline
\end{tabular}

All SNM areas at ANL lie within the fenced boundaries of the site. Vehicle access is by gates that are closed and locked when unattended by guards. Admittance to the site is by DOE or ANL employee identification badge, windshield identification sticker, visitor gate pass issued by the Security Division (SEC), or under escort and vouched for by an employee. Admittance to the site does not provide admittance to specially protected areas within the site where SNM are located. Personnel entering or leaving the site are subject to search for contraband items or the unauthorized possession of government property.

Security clearances and authorizations are provided on the basis of DOE or FBI investigations. DOE $Q$ clearances are required for custodial users of SNM; DOE L clearances, as a minimum, are required for regular access to SNMprotected areas or material access areas. Additionally, each person who has custodial use of SNM must be authorized by a division director and by the SPM director. 
Access controls are exercised by armed guards stationed at the portals to Category I material access areas or Category II protected areas, or by a system of closed-circuit television identification and electronic access controls. Entry to and exit from a given access area are controlled by guards through a single portal, with all other exits alarmed and locked to entry but with provision for emergency evacuation.

Searches for contraband items in SNM areas are conducted by having personnel pass through metal detector doorway monitors, by hand-held metal detectors, and by explosive detectors. X-ray equipment and qualified radiographers are available to assist in the evaluation of suspect items. All persons leaving a Category I material access area are searched by radiation-sensitive SNM detectors which may be either hand-held or walk-through SNM portal monitors.

All movement of SNM past a protected area perimenter must be authorized by the area SPM representative. The guard checks the authorizing document for signature and the seal on the transfer container for identification with the document authorizing transfer. Transportation of SNM between buildings is by armored truck.

\section{REFERENCES (Section 3)}

Argonne National Laboratory. 1973. "Illinois Health and Safety Manual." May 1, 1973.

Argonne National Laboratory. 1976. "Technical Specifications for the Argonne Thermal Source Reactor (ATSR)." March 1976.

Argonne National Laboratory. 1977a. "JANUS Reactor Technical Specifications." November 4, 1977.

Argonne National Laboratory. 1977b. "Waste Handling Procedures, Argonne National Laboratory, Illinois Site." June 1977.

Argonne National Laboratory. 1977c. Safety Analysis Report--The New Brunswick Laboratory. September 15, 1977.

Argonne National Laboratory. 1978. "Terrestrial and Aquatic Information Packages." Argonne, IL. December 15, 1978.

Argonne National Laboratory. 1981a. "Draft Environmental Assessment Related to the Decontamination and Decommissioning of the Argonne National Laboratory CP-5 Research Reactor." Prepared by the Division of Environmental Impact Studies for the U.S. Department of Energy. November 1981 (Draft).

Argonne National Laboratory. 1980b. "Environmental Assessment Related to the Conversions of Boilers No, 1 and No. 5 at Argonne National Laboratory." DOE/EA-0126; ANL/ES-107. Prepared by the Division of Environmental Impact Studies for the U.S. Department of Energy. December $1980.108 \mathrm{pp}$.

Baker, S.I. 1978. "Environmental Monitoring Report for Calendar Year 1977." Fermi National Accelerator Laboratory Report Fermilab-78/27. May 1, 1978. 
Benson, C. 1978. Personal communication (Illinois State Water Survey, Warrenville, IL).

Carter, R.F., B. Foy, and K. Stewart. 1960. "The Particulate Material Formed by the Oxidation of Plutonium." U.K. Atomic Energy Authority Report AERO. CONF. $/ 8$.

Chapman, D., and N. Chapman. 1975. "Fallow Deer, Their History, Distribution, and Biology." Terrence Dalton Ltd., Lavenham, England.

Commonwealth Edison Company. 1975a. "Dresden Nuclear Power Station, Radioactive Waste, Environmental Monitoring and Occupational Personnel Radiation Exposure." Semiannual reports to the U.S. Nuclear Regulatory Commission for the periods January through June and July through December 1975.

Commonwealth Edison Company. 1975b. "Zion Power Station, Radioactive Waste, Environmental Monitoring and Occupational Personnel Radiation Exposure." Semiannual reports to the U.S. Nuclear Regulatory Commission for the periods January through June and July through December 1975.

Dietrich, J.R. 1954. "Experimental Investigation of the Self-Limitation of Power During Reactivity Transients in a Subcooled, Water-Moderated Reactor, Borax-I Experiments." Argonne National Laboratory Report ANL-5323.

DuPage County Regional Planning Commission. 1978. "DuPage County Land Use Plan." January 1978 .

Electrical World. 1976. "Directory of Electric Utilities." 1976-1977, 85th ed. McGraw-Hill, Inc., New York, NY.

Golchert, N.W., T.L. Duffy, and J. Sedlet. 1981. "Environmental Monitoring at Argonne National Laboratory, Annual Report for 1980." Argonne National Laboratory Report ANL-81-23. March 1981.

Gonzales, M., et al. 1976. "Performance of Multiple HEPA Filters Against Plutonium Aerosols." Los Alamos Scientific Laboratory Report LA-6456. November 1976.

Illinois Environmental Protection Agency. 1976. "1976 Annual Air Quality Report." Division of Air Pollution Control, Springfield, IL.

International Commission on Radiological Protection. 1959. "Report of Committee II on Permissible Dose for Internal Radiation." ICRP Publ. 2. Pergamon Press, New York.

International Conference of Building Officials. 1976. "Uniform Building Code - 1976 Edition." Whittier, CA. p. 149.

Kato, W.Y., et al. 1970. "Final Safety Analysis Report on the Use of Plutonium in 2PR-6 and -9." Argonne National Laboratory Report ANL-7442. February 1970.

National Oceanic and Atmospheric Administration and U.S. Geological Survey. 1977. "United States Earthquakes, 1975." 
Northeastern Illinois Planning Commission. 1977. "1977 Regional Data Report." September 1977.

NUS Corporation. 1979a. "Decommissioning Plan, Building 335 - Nuggernaut." October 1979.

NUS Corporation. 1979b. "Decommissioning Plan, Building 331 - EBWR." October 1979.

Opelka, J.H., R.L. Mundis, G.J. Marmer, J.M. Peterson, B. Siskind, and M. Kikta. 1979. "Particle-Accelerator Decommissioning." Argonne National Laboratory Report ANL/ES-82. December 1979. 127 pp.

Patty, F. (ed.). 1962. "Industrial Hygiene and Toxicology. Volume II: Toxicology." 2nd rev. ed. John Wiley \& Sons, New York. p. 847.

Reynolds, G.W. 1970. "A Practical Look at Tornado Forces." Presented at the University of Wisconsin Tornado Conference, April 26-28, 1970.

Sedlet, J., and T.L. Duffy. 1972. "A Study of Radioactive and Toxic Elements on the ANL Peripheral Land." Argonne National Laboratory unpublished report. January 14, 1972.

Texas Tech University. 1975. "Development of a Windspeed Risk Model for the Argonne National Laboratory Site." Unpublished report. Institute for Disaster Research and Department of Civil Engineering. May 1975.

Turner, D.B. 1970. "Workbook of Atmospheric Dispersion Estimates." Publ. No. AP-26. U.S. Environmental Protection Agency, Office of Air Programs.

U.S. Atomic Energy Commission. 1975. "Operational Accidents and Radiation Exposure Experience Within the United States Atomic Energy Commission, 1943-1975." WASH-1192.

U.S. Bureau of the Census. 1981. "County Business Patterns 1979, Illinois." CBP-75-15. U.S. Department of Commerce. July 1981.

U.S. Energy Research and Development Administration. 1976. "Safety Standards for the Packaging of Fissile and Other Radioactive Materials." ERDA Manual Chapter 0529. December 21, 1976.

U.S. Energy Research and Development Administration. 1977a. "Draft Environmental Impact Statement--Rocky Flats Plant Site, Golden, Colorado." Volume 1. ERDA-1545-D. September 1977. p. 2-172.

U.S. Energy Research and Development Administration. 1977b. "Standards for Radiation Protection." ERDA Manual Chapter 0524. March 30, 1977.

U.S. Environmental Protection Agency. 1976. "Drinking Water Regulations, Part 141--Interim Primary Drinking Water Regulations." Fed. Regist. 41:28401.

U.S. Environmental Protection Agency. 1977. "Radiological Quality of the Environment in the United States, 1977." EPA 520/1-77-009. September 1977. 
U.S. Environmental Protection Agency. 1977. "User's Manual for Single-Source (CRSTER) Model." EPA-450/2-77-013. Office of Air and Water Management.

U.S. Geological Survey. 1973. "Water Resources Data for Illinois, Water Year 1973." U.S. Geol. Surv. Water-Data Rep. 16-73-1. pp. 101, 109-111, 118.

U.S. Nuclear Regulatory Commission. 1976. "Preparation of Environmental Reports for Nuclear Power Stations." Regulatory Guide 4.2 (Revision 2). July 1976.

U.S. Nuclear Regulatory Commission. 1977. "Calculation of Annual Doses to Man from Routine Releases of Reactor Effluents for the Purpose of Evaluating Compliance with 10 CFR Part 50, Appendix I, Regulatory Guide 1.109. Revision 1. October 1977.

U.S. Occupational Safety and Health Administration. 1978. "Occupational Exposure to Benzene." Fed. Regist. 43(29):5963 (February 10). 


\section{UNAVOIDABLE ADVERSE ENVIRONMENTAL IMPACTS}

The unavoidable adverse environmental impacts of ANL are largely those common to ordinary establishments employing a large number of people. With the exception of the release of small, nonhazardous amounts of radioactivity and nonradioactive chemicals, the effects of ANL on the environment are similar to, and generally smaller than, those of most nonmanufacturing activities employing a similar number of people. These basic environmental impacts of ANL and similar establishments are those due to the consumption of natural resources, the occupation of land that could be left in its natural state or used for other purposes, and the creation of wastes that may be deleterious to the environment or harmful to the general population. Resources used and environmental impacts are summarized in Table 4.1 and in the following discussion.

The major natural resource consumed at ANL is the fuel used for onsite steam generation and for generation of the purchased electric power. Although substantial amounts of natural gas, coal, and electric power are used, these resources are used carefully and in amounts not unreasonable or excessive for the number of people employed and the work done.

The major source of process cooling water is the Chicago Sanitary and Ship Canal, from which onsite ANL withdrawal is infinitesimal. Potable water is obtained from onsite wells. Although well water in the local areas is a diminishing natural resource, ANL usage corresponds largely to necessary human usages, and the amounts cannot be decreased to any significant extent.

The total land currently occupied by ANL is 688 ha, of which about 81 ha are covered by buildings, roads, parking lots, and other structures. The remainder of the land either is in grass and pine plantations or has been allowed to revert to a natural state. The current usage of the ANL site is in conformity with the DuPage County land-use plan and cannot properly be considered an adverse impact.

The only site wastes that are unique to ANL operations are small releases of radiation, radioactive materials, and chemicals. The effects of the radioactive releases are very slight, being essentially unmeasurable beyond the site boundary. The reported radiation doses are theoretical calculations and not local measurements. In each case, the releases are far below acceptable limits.

Chemical effects on the air, water, and ground are also very slight and generally undetectable offsite, except for some minor effects on Sawmill Creek below the sewer discharge. Sanitary releases to Sawmill Creek reflect a high level of treatment and, with rare exceptions, are within state standards. 
Table 4.1. Unavoidable Adverse Impacts of Argonne Operations

I. Approximate Resources Used Annually

$3.0 \times 10^{7} \mathrm{~m}^{3}$ of natural gas

$3,000 \mathrm{~m}^{3}$ of fuel oil

$2.5 \times 10^{8} \mathrm{kWh}$ of electric power

$1.4 \times 10^{6} \mathrm{~m}^{3}$ of well water

$7.1 \times 10^{5} \mathrm{~m}^{3}$ of canal water

$500 \mathrm{~m}^{3}$ of gasoline and diesel fuel

45,000 metric tons of high-sulfur coal

II. Land Use

688 ha total

81 ha developed

III. Approximate Effects of Wastes

500 person-rem/yr total radiation dose within $80-\mathrm{km}$ radius

$6 \mathrm{mrem} / \mathrm{yr}$ maximum resident whole body dose

Undetectable increases in radioactivity and chemicals in Des Plaines River

Small increases in $\mathrm{SO}_{2}$, NOx, and particulate matter in air 


\section{ALTERNATIVES}

Alternatives to the continued operation of ANL at the current site are evaluated in this section. Included as alternatives are: total abandonment of the site and work; total or partial transfer of the work to other areas and institutions; and modifications of current operations without essentially changing the character of the programs.

\subsection{TERMINATION AND ABANDONMENT}

The termination and abandonment of ANL operations includes the options of either closing the Laboratory with no-provisions for transferring the work and personnel elsewhere, or transferring all or part of the work to other institutions.

\subsubsection{Termination Without Resumption Elsewhere}

Nationally, the major consequence of closing all ANL programs without resumption elsewhere would be the loss of societal benefits that accrue from the ongoing energy research and development programs in the physical, biomedical, and environmental sciences.

The major regional socioeconomic impact would be the unemployment of more than 4500 ANL employees. Currently, ANL is one of the largest employers in DuPage County, with an annual payroll of approximately $\$ 125$ million. The closure of ANL would create serious local unemployment problems, particularly for those employees with highly specialized job functions who could not be readily absorbed into the local job market.

Although ANL employees live throughout the Chicago metropolitan area, it is estimated that more than $50 \%$ of them reside within $16 \mathrm{~km}$ and $85 \%$ within $24 \mathrm{~km}$ of the ANL site. The closing of ANL would impact local communities such as Downers Grove, Naperville, Bolingbrook, and Lemont. Lemont, for example, derives about $10 \%$ of its income from ANL personnel.

Besides increased unemployment and loss of local income, the economic loss to vendors due to the termination of ANL contracts would be substantial. ANL purchases approximately $\$ 80$ million of regional services, equipment, and supplies annually. The termination of ANL would mean a loss of business and a subsequent decrease in revenues to such vendors.

ANL can be considered a basic industry through its effects on the local socioeconomic structure. It derives its operating income from an outside source (the federal government) and recirculates much of it within the local economy through employee salaries and payments to vendors. This recirculation of money within the local economy (the multiplier effect) is important to the economic well-being and growth of many local communities surrounding ANL. The 
elimination of ANL personnel and their associated earnings and the elimination of the need for support services, equipment, and supplies would have a negative effect on the economic multiplier of the local area by reducing the flow of money into the local supporting economic structure (rents, saving deposits, food, clothing, etc.). Also among the local losses would be a $\$ 25,000$ ANL annual contribution to DuPage County for payment in lieu of taxes.

If ANL is closed, the site could either be retained for other governmental functions or sold and used for other purposes. Some of the possible alternative uses of the ANL site would include agricultural, residential, commercial, industrial, institutional, recreational, or open space. The open space and research and development character of ANL land usage are consistent with the DuPage County land-use plan. The replacement of ANL with types of development other than what currently exists (e.g., industry, medium- or high-density. residential) would probably not be consistent with the existing land-use plan and growth trends for the county. Describing the potential for various uses of the ANL site are beyond the scope of this assessment and will not be discussed further in this report.

Costly decommissioning, decontamination, and dismantling of various site facilities would be required prior to the site being used for other purposes. Until an alternative use could be established, maintenance and security costs would continue to be incurred.

The socioeconomic benefits of closing ANL would be federal savings of tax dollars spent on the annual operation of ANL (about $\$ 200$ million annually) and such economic benefits derived from selling the Laboratory's facilities and land.

\subsubsection{Termination With Resumption Elsewhere}

Research and engineering developments of high quality are largely the work of talented individuals who are provided. the necessary support and environment to enable them to do their work. A surplus of such individuals does not exist, and if the work of ANL is to be continued elsewhere, these people must be relocated to some presumably more favorable locations. The justification for the relocation must be either a significant amelioration of negative impacts on the local community, an improvement in the work environment for the transferred people, or a significant cost savings. Associated with the transfer would be the large costs of moving or rebuilding the equipment now at ANL and extensive delays before the equipment could be used again. Probably, new building facilities would be required for at least some of the transferred personnel. For the transferred people, the moves would mean disruptions, extra expenses, and delays in their work. Some experienced personnel would most likely be lost from ongoing projects.

As described in earlier sections of this assessment, the deleterious environmental effects of ANL operations have been slight and work is constantly going on to decrease even these minor effects. Similarly, the potential effects of accidents are very small and their occurrence very improbable. The open space and the research and development character of ANL land usage are consistent with and supported by the DuPage County land-use plan. 
With respect to working conditions of the staff, ANL has excellent physical facilities and provides a fine interdisciplinary atmosphere for scientific and engineering research. The Chicago area and DuPage County provide many possibilities for productive interaction of the ANL staff with colleagues and students at the many academic and research institutions and industries of the area.

The termination of ANL operations with resumption elsewhere would produce many of the socioeconomic impacts as discussed in Section 5.1.1. In addition, various costs would be incurred for the relocation of ANL personnel, for the recruitment and training of people for positions not filled by ANL personnel unwilling to relocate, and for the stopping and restarting of transferred programs and projects. Costs would also be incurred for the disassembly, transportation, and reassembly of the various ANL facilities required at the relocation site.

Socioeconomic impacts such as the increased need for community services (water, sewer, etc.) could result at and around the new location where ANL operations are resumed. The degree of such impacts would depend on the site of relocation and the extent of program resumption.

The communities surrounding the site where ANL operations are resumed would receive the local socioeconomic benefits of increased employment and income that would be lost to the communities surrounding the existing ANL site. The federal government could receive economic benefits from the selling of various ANL facilities and land.

\subsection{PARTIAL TERMINATION OF OPERATIONS}

In a large multidisciplinary institution such as ANL, it is customary to phase out completed or unproductive programs. The remaining programs are justified in terms of their value to the nation. Ongoing programs are constantly examined to determine whether they should be continued or modified. Evaluating and minimizing the associated environmental impacts are integral parts of the programs.

Partial closure of the ANL facilities or partial transfer of programs to other facilities would produce many of the same impacts and benefits as discussed in Sections 5.1.1 and 5.1.2, but to a lesser extent. The degree of impact would depend on the type and number of programs discontinued or transferred. It is beyond the scope of this EA to identify and discuss the numerous combinations of possible options involving partial termination or transfer of ANL programs.

\subsection{LIMITATION OF ENVIRONMENTAL IMPACTS}

Alternative methods of operation and waste disposal that do not essentially change ongoing programs are considered in this section. As mentioned earlier, ANL programs are continually being examined with respect to their basic viability, safety, and environmental impacts. Where deficiencies are found, plans are made for correcting them, and when necessary, funds are requested for construction and materials needed for the corrections. In past years, several such corrective projects have been carried out. Among these 
are improvements in the handling of chromium compounds and mercury, and changes in several of the plutonium use and storage facilities for increased protection against dispersion of plutonium by tornadoes or accidents. The latter is just one part of the overall Safeguards and Security Improvement Program (SSIP) described in Section 3.7. The SSIP will have a net positive environmental effect by providing greater protection of the environment against natural events, theft, and sabotage.

The ANL master site plan contains details of a number of projects that will be carried out as funds become available. Among these projects are several with the primary purpose of environmental protection. Some of these environmentally oriented projects are as follows:

(a) Energy-saving modifications, including conversion of the boiler plant to use coal (completed in 1981).

(b) Repiping of major cooling tower blowdowns to discharge from a single onsite outfall.

The conservation of energy is an important concern of ANL. A three-phase energy management plan has been drawn up: individual employee actions, such as turning off unnecessary light, heat, and cooling; minor adjustments and optimization of existing heating and ventilating systems; and major retrofit modifications of existing building systems.

Ventilation of buildings, in particular laboratories where dangerous materials are handled, has been found to be one of the most energy-wasteful operations at ANL. An extensive program of improved controls and redesign and construction of basic components is expected to lower energy consumption by 20 to $30 \%$. 


\section{RELATIONSHIP BETWEEN SHORT-TERM USE AND LONG-TERM PRODUCTIVITY}

The purpose of this section is to consider the relationship between the current use of the ANL site (short-term) and future (long-term) uses of the site after ANL operations have ceased. Does the operation of the Argonne National Laboratory inhibit or prevent future uses of this land, and are there other uses that might be more beneficial and less inhibitive of future uses?

The land occupied by ANL had not been highly productive in agriculture in the past and, in view of the current development of the area, it is unlikely that anything but marginal agricultural units would have remained in the absence of ANL. A probable alternative development of the area would have been housing. However, a balanced community requires that employment opportunities as well as housing be present, and ANL provides such an alternative. As a research and development institution, much of the beneficial impact of ANL is expected in the future. Thus, long-term productivity may be expected to be enhanced by the current work of ANL.

More than $80 \%$ of the ANL site is occupied by various types of planted or naturally started vegetation. There is, at most, very localized and insignificant radioactive or chemical contamination, and almost all of the land could, with little preparation, be used for whatever purpose society finds desirable. Similarly, only a very few of the buildings or other facilities are so specialized or contaminated that they could not be used for a variety of purposes. Although exact costs are not available, it is likely that all of the current areas or buildings, for which future uses might otherwise be inhibited, could be removed or decontaminated.

In summary, the current uses of the ANL site directly contribute to the enhancement of future productivity; they do not in any way inhibit future productive uses of the area. 


\section{RELATIONSHIP OF CONTINUED OPERATION TO LAND-USE PLANS, POLICIES, AND CONTROLS}

Argonne National Laboratory is located on federally owned land and is subject to federal rules governing water and air quality and to federal environmental protection laws. Compliance with these rules is discussed in several sections of this statement.

There are no federal laws specifically governing land use on areas such as the ANL site. However, the National Environmental Policy Act of 1969 requires that an environmental evaluation be undertaken wherein possible environmental impacts of any major federal action are examined and made public. The effect of new and continuing actions on land use must be considered.

ANL was established in DuPage County before any comprehensive land-use plans were available, and it is doubtful that current local government land use plans could have any legal authority over the ANL site. It is nevertheless of interest to show that the continued operation of ANL is totally consistent with the present land use plans of DuPage and neighboring Cook and Will counties.

Since the time ANL was established, the Northeastern Illinois Planning Commission (1977) was set up by the state legislature to provide regional goals and coordinate the land-use plans of the six northeastern Illinois counties. The counties have each established planning commissions to provide detailed land-use plans for their areas. Briefly, the purposes of these plans are to provide a balance of land uses and a maximum of economic, recreational, and esthetic benefits from the use of the land.

The proposed land-use plans for DuPage County (DuPage Co. Region. Plan. Comm. 1978) largely continue the proportions of the current uses, i.e., mostly low-density residential with smaller fractions of other uses. About $80 \%$ of the total county land is expected to be developed by the year 2000 . The largest relative increase is in the moderate-density residential category, which is projected to go from 1.4 to $3.3 \%$ of the developed area. DuPage County is considered to be a highly desirable area for the "office, research and development" category, and the plan calls for a doubling of this area. The land-use plan specifically mentions ANL in this category. An important concern of the plan is the establishment of open spaces. These areas are needed for recreation, but are also important in providing buffers and connecting green space to serve as linkages between the urbanized communities. Sensitive natural resource areas such as floodplains and water recharge areas, which in part constitute the Argonne-Waterfall Glen Nature Preserve area, are protected by the open space limitations.

The operation of Argonne is, therefore, consistent with the DuPage County land-use plans in several ways. The Laboratory makes a substantial contribution 
to the desired "office, research and development" category of the land-use plan, and ANL itself, as well as the surrounding forest preserve that was originally part of ANL, contribute to the desired open space of the land-use plan.

REFERENCES (Section 7)

DuPage County Regional Planning Commission. 1978. "DuPage County Land Use Plan." January 1978.

Northeastern Illinois Planning Commission. 1977. "Comprehensive General Plan for the Development of the Northeastern Illinois Counties Area." August 18, 1977. 


\title{
8. IRREVERSIBLE AND IRRETRIEVABLE COMMITMENTS \\ OF RESOURCES
}

\begin{abstract}
Almost every human activity consumes small amounts of fossil fuels, minerals, and other natural resources that exist on the earth only in finite quantities. To the extent that the materials are scarce and the use is destructive of the material, a significant impact is made on the environment. At ANL, the use of such limited and nonrenewable resources is very small, although some consumption is essential to the operation of the facility (see Section 4). Nevertheless, ongoing conservation activities are aimed at reducing the consumption of nonrenewable resources to the lowest levels commensurate with the continuation of ANL programs.
\end{abstract}

Few if any other future land uses would be inhibited by the current use of land by ANL. The building and laboratory materials are generally common or, if scarce, are used in very small quantities. Fossil fuels are being used, but as discussed elsewhere, the use is consistent with long-range goals. Small amounts of uranium-235 are used in onsite reactors. This usage is negligible in comparison with commercial power reactor use. In summary, the use of limited and nonrenewable resources at ANL is very small, and where such use is necessary, it is believed to be in the national interest. 


\section{LIST OF PREPARERS}

This Environmental Assessment was prepared by Argonne National Laboratory with technical input from various ANL Divisions. Individuals having primary responsibility for preparation of this document were:

Richard D. Olsen, Project Leader for Final Draft Ira Charak, Project Leader for Preliminary Draft

Division and Program coordinators responsible for the technical contributions from specific ANL Divisions and Programs were:

Stephen Ballou, EES

Manuel Bretcher, AMD

Herbert Brown, CEN

Charles Cheever, PFS

Joseph Darby, MSD

Daniel Finucane, CT

John Foley, PS

William Galik, CS

Donald Grube, BIM

Ernest Hutter, EBR

Darwyn Johnson, SUP

Robert King, AMD

William Kline, ATS

William Livernash, MSD

Emil Martinec, OTD

Robert Mason, NBL
James McCreary, CHM

F. Paul Mooring, PHY

Donald O'Neil, OHS

Fred Pancner, OTD

Remo Puricelli, PFS

Richard Ramos, SEC

Merlin Schultz, EL

Arthur Shuck, SSIP

John Simon, ENG

Norman Swanson, ENG

Thomas Terlep, CEA

Ernest Van Berkum, SPM

Fred Vaslow, EIS

John Venard, MSD

Robert Wehrle, ARF

Thomas Worlton, RRO

Editing of the final draft was done by Dimis Wyman, EIS. 
10. AGENCIES CONSULTED

The following agencies were consulted during preparation of this document:

DuPage County Forest Preserve

DuPage County Planning Commission

Illinois Department of Conservation

Illinois State Water Survey

National Oceanic and Atmospheric Administration

Northeastern Illinois Planning Commission

U.S. Fish and Wildlife Service

U.S. Geological Survey 
APPENDIX A. LIST OF ABBREVIATIONS

\begin{tabular}{|c|c|}
\hline AGHCF & Alpha-Gamma Hot Cell Facility \\
\hline ALARA & As Low As Reasonably Achievable \\
\hline ANL & Argonne National Laboratory--Illinois site \\
\hline AP & Applied Physics Division \\
\hline ATSR & Argonne Thermal Source Reactor \\
\hline AUA & Argonne Universities Association \\
\hline BIM & Biological and Medical Research Division \\
\hline BOD & Biochemical Oxygen Demand \\
\hline $\mathrm{CHCS}$ & Criticality Hazards Control Statement \\
\hline $\mathrm{CHM}$ & Chemistry Division \\
\hline $\mathrm{CP}-5$ & Chicago Pile-Five Reactor \\
\hline DOE & United States Department of Energy \\
\hline DOT & United States Department of Transportation \\
\hline EA & Environmental Assessment \\
\hline EBR-II & Experimental Breeder Reactor-II Project \\
\hline EBWR & Experimental Boiling Water Reactor \\
\hline EPA & $\begin{array}{l}\text { Environmental Protection Agency (refers to either United } \\
\text { States or state agency) }\end{array}$ \\
\hline FBI & Federal Bureau of Investigation \\
\hline GI & Gastro-Intestinal \\
\hline HEPA & High-Efficiency Particulate Air (refers to air filters) \\
\hline ICRP & International Commission on Radiological Protection \\
\hline IPNS & Intense Pulsed Neutron Source \\
\hline JRO & JANUS Reactor Operations \\
\hline LWR & Light Water Reactor \\
\hline MM & Modified Mercalli Scale \\
\hline MSD & Materials Science Division \\
\hline MSL & Mean Sea Level \\
\hline NBL & New Brunswick Laboratory \\
\hline NPDES & National Pollutant Discharge Elimination System \\
\hline NRC & United States Nuclear Regulatory Commission \\
\hline
\end{tabular}




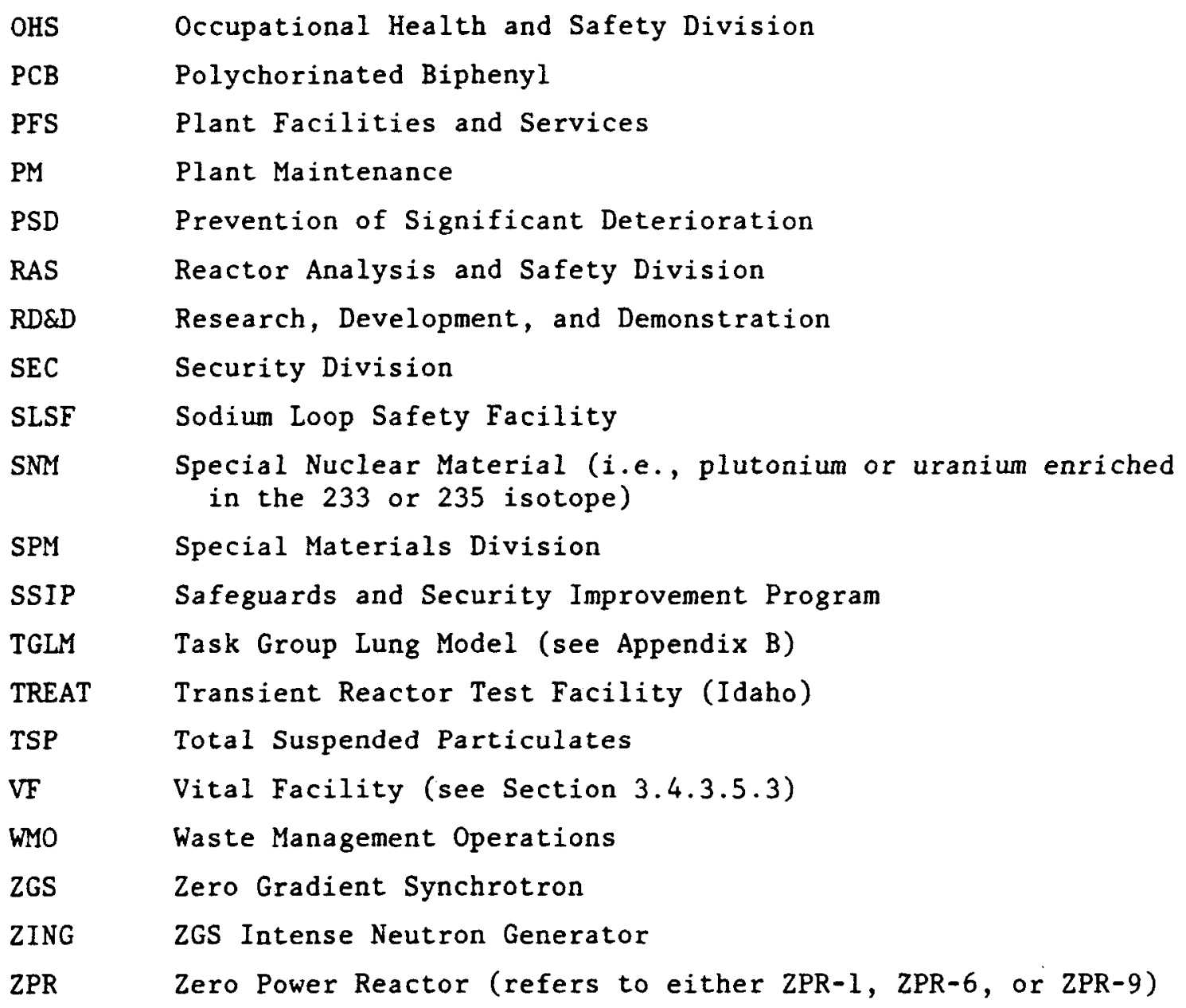




\section{APPENDIX B. ATMOSPHERIC DISPERSION AND DOSE MODELS}

The first step in estimating the impact of the accident releases is the establishment of appropriate source terms. This was treated in Section 3.4.3. In this appendix, the various models, assumptions, and data used to translate those source terms into human biological effects are described. The computations require the calculation of: first, the downwind concentration of the particular effluent; second, the amount of the effluent inhaled; and third, the somatic effect of the inhaled effluent. In general, to the extent possible, the models, assumptions, and basic data are commensurate with current guidelines provided in the NRC regulatory guides for power reactor safety and/or environmental analyses.

\section{B. 1 ATMOSPHERIC DISPERSION MODEL}

The ground-level pollutant concentration downwind of an atmospheric release is typically calculated by using a Gaussian distribution, together with appropriate standard deviations, to characterize the plume spread (cf. Turner 1970). In this assessment, almost all routine and accident release concentrations have been calculated by the XOQDOQ code which employs this technique (Sagendorf and Goll 1977). The only exception is the tornadodispersion analysis, which is described in detail in Section 3.4.3.5.3.

The meteorological parameters used in the XOQDOQ calculation are derived from ANL site data. Those data are annually averaged, and correspond to the "50\% probability level" called for in NRC Regulatory Guide 4.2 (U.S. Nucl. Reg. Comm. 1976).

The results of the calculation are values of $\chi / Q$ as a function of distance and direction from the release point. The chlorine release accident (Section 3.4.3.4.1) occurs about $0.4 \mathrm{~km}$ northeast of the nearest site boundary fence and about $1.6 \mathrm{~km}$ from the nearest residence. For these cases, $\chi / Q$ is $1.6 \times 10^{-6}$ and $7.3 \times 10^{-7} \mathrm{~s} / \mathrm{m}^{3}$, respectively. The former is the largest site boundary value; the greater distances to other site boundaries more than compensate for increases in $X / Q$ due to wind variability by sector bearing.

For the explosion and fire analyses (Sections 3.4.3.1 and 3.4.3.2, respectively), a survey of buildings susceptible to those events was conducted. Values of $x / Q$ at different boundaries were determined for each such building as a potential release point. The largest value of $X / Q$ was found to be $1 \times 10^{-6} \mathrm{~s} / \mathrm{m}^{3}$. For conservatism, this value was arbitrarily increased $75 \%$ to $1.75 \times 10^{-6}$.

The largest $X / Q$ value calculated was for a distance of $0.4 \mathrm{~km}$ and was $2.2 \times 10^{-6} \mathrm{~s} / \mathrm{m}^{3}$. For the cobalt-60 release (Section 3.4.3.4.2), the nearest site boundary is about $150 \mathrm{~m}$ from the source; however, the nearest resident is 
well beyond $0.4 \mathrm{~km}$. Therefore, for this accident, the value $2.2 \times 10-6 \mathrm{~s} / \mathrm{m}^{3}$ was used and is considered adequately conservative.

Finally, to calculate the downwind concentration of a particular pollutant, the appropriate value of $X / Q$ is multiplied by $Q$, the source term. If $Q$ is a continuous-release source, e.g., with units of $\mathrm{Ci} / \mathrm{s}$, then $X$ will have units of $\mathrm{Ci} / \mathrm{m}^{3}$. If $Q$ is an instantaneous point source, e.g., with units of $\mathrm{C} i$, then $X$ will represent the total integrated exposure during passage of the cloud, with units of $\mathrm{Ci}-\mathrm{s} / \mathrm{m}^{3}$.

\section{B. 2 INHALATION MODEL}

The amount of material inhaled is simply the concentration at the receptor's location, as determined in Section B.I, multiplied by the breathing rate. That is,

$$
I_{i}=x_{i} \cdot B
$$

where:

$$
\begin{aligned}
& I_{i}= \text { amount of nuclide } i \text { inhaled: } \mu C i \text { for a puff release, } \\
& \mu C i / d \text { for a continuous release }
\end{aligned}
$$

The daily average breathing rate of $20 \mathrm{~m}^{3} / \mathrm{d}$ is used for all inhalation calculations.

\section{B.3 DOSE MODEL}

The term "dose commitment" refers to the total dose to a reference body organ arising from the deposition of one or more radionuclides in that organ. The dose is calculated from the time of nuclide deposition to the end of the individual's life. Typically, "lifetime" dose commitments are based on a 50-yr exposure duration.

The major pathway for human exposure considered in this statement is inhalation; the nuclide is deposited in the pulmonary region and subsequently may be translocated to other body organs, depending upon its solubility. At least two inhalation models are currently in use: the lung model of the International Commission on Radiological Protection (1959), hereafter referred to as the ICRP model; and the newer model of the Task Group on Lung Dynamics. (1966), often referred to as the Task Group Lung Model, or TGLM. To date, the TGLM has not been widely used in dose calculations. For the purposes of this assessment, dose calculations are based on the ICRP model for the main reason that current published dose conversion factors (to be discussed below), including those used by the NRC in licensing actions, are all based on the ICRP model. 
To calculate the lifetime organ dose commitment due to the inhalation of a nuclide, the amount of material inhaled, $I_{i}$ from Equation B-1, is multiplied by a dose conversion factor, so that

$$
D_{i j}=K_{i j} \cdot I_{i}
$$

where:

$$
\begin{aligned}
D_{i j}= & \text { the } 50-y r \text { dose commitment to organ } j \text { due to inhala- } \\
& \text { tion of nuclide } i \text {, rem } \\
K_{i j}= & \text { dose conversion factor to convert the amount of inhaled } \\
& \text { nuclide } i \text { to a } 50-y r \text { dose commitment, rem } / \mu C i \text { inhaled }
\end{aligned}
$$

Published values of $K_{i j}$ are usually based on a single uptake of the nuclide over a period of time that is short compared with the 50-yr exposure time; therefore, in Equation $B-2, I_{i}$ has units of microcuries, as in a puff release (see Equation $B-1$ ). The values of $K_{i j}$ for the particular selected adult organs used in this statement are presented in Table B.l for the nuclides of interest.

The dose commitment from a continuous release can be readily derived from the single-uptake case for all organs, except the gastrointestinal (GI) tract,* as follows. For clarity, subscripts to distinguish nuclides and organs are omitted from those parameters that are organ- and nuclide-dependent. For a continuous release, the amount of material inhaled, from Equation B-l, is I $\mu \mathrm{C} i / d$. Then,

$$
d(D R)=I \cdot f \cdot C \cdot d t
$$

where:

$$
\begin{aligned}
& D R=\text { dose rate to the organ, rem/d } \\
& f=\text { fraction of the inhaled nuclide that is deposited } \\
& \text { in the organ } \\
& C=\text { dose rate to the organ from the deposited nuclide, } \\
& \mathrm{rem} / \mathrm{d}-\mu \mathrm{Ci} \\
& t=\text { time, } d
\end{aligned}
$$

\footnotetext{
The dose commitment to the GI tract is proportional only to the total nuclide uptake in that organ for long-lived nuclides, since the residence time in the GI tract is very short ( $\sim$ l d) compared with the nuclide half-life. Therefore, the dose commitment for a continuous release is simply the value computed from Equation B-2, with $I_{i}$ equal to the total amount of nuclide $i$ inhaled over the 50-yr exposure period, and using the appropriate $K_{i j}$ from Table B.I.
} 
Table B.1. Lifetime Adult Organ Dose Commitment Due to Inhalation of $1 \mu \mathrm{Ci}$ of Nuclide

\begin{tabular}{|c|c|c|c|c|c|c|c|}
\hline \multirow[b]{2}{*}{ Nuclide } & \multicolumn{7}{|c|}{ Dose Commitment (rem) per Organ ${ }^{a}$} \\
\hline & Lung (I) ${ }^{b}$ & Bone (S) ${ }^{b}$ & Bone (I) ${ }^{c}$ & Liver $(S)^{b}$ & Liver(I) ${ }^{c}$ & $G I(S)^{d}$ & $G I(I)^{e}$ \\
\hline Cobalt -60 & 0.74 & - & - & 0.006 & $0.0015^{\mathrm{e}}$ & 0.029 & 0.036 \\
\hline Uranium-234 & 53.9 & 21.1 & 10.6 & - & - & 0.031 & 0.038 \\
\hline Uranium-235 & 50.6 & 20.2 & 10.1 & - & - & 0.039 & 0.048 \\
\hline Uranium-236 & 51.7 & 20.2 & 10.1 & - & - & 0.029 & 0.036 \\
\hline Uranium-238 & 47.3 & 19.4 & 9.7 & - & - & 0.027 & 0.034 \\
\hline Plutonium-238 & 189 & 5705 & 2853 . & 816. & 408 & 0.036 & 0.045 \\
\hline Plutonium-239 & 177 & 6559 & 3280 . & 896. & 448 & 0.033 & 0.041 \\
\hline Plutonium-240 & 177 & 6551 & 3276 . & 896. & 448 & 0.034 & 0.042 \\
\hline Plutonium-241 & 0.16 & 124. & 62. & 6.4 & 3.2 & $7.0 \times 10^{-4}$ & $8.7 \times 10^{-4}$ \\
\hline Plutonium-242 & 171 & 6080 & 3040 & 862. & 431. & 0.033 & 0.041 \\
\hline Americium-241 & 62.6 & 2069 & 1035. & 717. & 359. & 0.037 & 0.046 \\
\hline
\end{tabular}

${ }^{a} I=$ insoluble; $S$ = soluble; - = no data available.

brom Killough and McKay (1976).

Calculated from International Commission on Radiological Protection (1959) and Killough and McKay (1976).

dCalculated from International Commission on Radiological Protection (1959) and Hoenes and Soldat (1977).

Erom Hoenes and Soldat (1977); liver (I) value for cobalt-60 adjusted upward to be consistent with Table B.3 data. 
The total dose commitment, then, is

$$
D C=\int_{0}^{T} I \cdot f \cdot C \cdot d t \int_{t}^{T} \exp [-\lambda(T-t)] d t
$$

where:

$$
\begin{aligned}
& D C=\text { lifetime organ dose commitment, rem } \\
& \lambda=\text { effective nuclide decay constant in the organ, } d-1 \\
& T=\text { dose commitment period, } d \\
& \text { (For these calculations, } T=50 \times 365=18,250 \mathrm{~d} \text { ) }
\end{aligned}
$$

Finally, integrating Equation B-4,

$$
D C=\frac{I \cdot f \cdot C}{\lambda}\left\{T-\frac{l}{\lambda}[1-\exp (-\lambda T)]\right\}
$$

or,

$$
D C=I \cdot f \cdot C \cdot F
$$

where:

$$
F=\frac{1}{\lambda}\left\{T-\frac{1}{\lambda}[1-\exp (-\lambda T)]\right\}
$$

The term $C$ in Equation B-6 is calculated from the well-known equation

$$
C=51.2 \frac{E}{\mathrm{~m}} \text {. }
$$

where:

$$
\begin{aligned}
E= & \text { effective energy absorbed in the organ per nuclide } \\
& \text { distintegration, } \mathrm{MeV} \\
\mathrm{m}= & \text { organ mass, } 8
\end{aligned}
$$

Using values of $E$ and $m$ for each nuclide and organ from Hoenes and Soldat (1977), the values of $C$ were calculated and are given in Table B.2.

Values of $f$ for use in Equation B-6 were either reproduced or calculated from data of the International Commission on Radiological Protection (1959) and are given in Table B.3. Finally, the values of $F$ from Equation B-6 were calculated for the various nuclides and organs and are listed in Table B.4. 
Table B.2. Adult Organ Dose Rate Due to Deposition of $1 \mu \mathrm{Ci}$ of Nuclide

\begin{tabular}{|c|c|c|c|c|}
\hline \multirow[b]{2}{*}{ Nuclide } & \multicolumn{4}{|c|}{ Dose Rate (rem/d) per Organ } \\
\hline & Lung & Bone ${ }^{a}$ & Liver & GI \\
\hline Cobalt -60 & 0.038 & - & 0.022 & 0.15 \\
\hline Uranium-234 & 2.5 & 1.8 & - & 0.16 \\
\hline Uranium-235 & 2.4 & 1.7 & - & 0.21 \\
\hline Uranium-236 & 2.4 & 1.7 & - & 0.15 \\
\hline Uranium-238 & 2.2 & 1.6 & - & 0.15 \\
\hline Plutonium-238 & 2.9 & 2.0 & 1.7 & 0.19 \\
\hline Plutonium-239 & 2.7 & 2.0 & 1.6 & 0.18 \\
\hline Plutonium-240 & 2.7 & 2.0 & 1.6 & 0.18 \\
\hline Plutonium-24l & 0.003 & 0.1 & 0.03 & 0.003 \\
\hline Plutonium-242 & 2.6 & 1.8 & 1.5 & 0.17 \\
\hline Americium-241 & 2.9 & 2.0 & 1.7 & 0.20 \\
\hline
\end{tabular}

In order to facilitate the calculation of continuous release dose commitments, a dose commitment ratio (DCR) was calculated. This is the ratio of dose commitment for a puff release to dose commitment for a continuous release, where the amount of nuclide inhaled for the puff case is $50 \times 365$, or 18,250 times the daily inhalation rate for the continuous release. That is, referring to Equations $B-2$ and $B-6$,

$$
\mathrm{DCR}=\frac{18,250 \cdot \mathrm{K}_{i j}}{\mathrm{f} \cdot \mathrm{C} \cdot \mathrm{F}}
$$

The dose commitment for the continuous release, therefore, is simply obtained by calculating the "equivalent" puff dose commitment and dividing by the DCR. Calculated values of DCR are given in Table B.5. 
Table B.3. Fraction of Inhaled Material Deposited in Reference Organ, $f^{a}$

\section{Fraction Per Element ${ }^{b}$}

\begin{tabular}{|c|c|c|c|c|c|c|c|c|}
\hline \multirow[b]{2}{*}{ Organ } & \multicolumn{2}{|c|}{ Cobalt } & \multicolumn{2}{|c|}{ Uranium } & \multicolumn{2}{|c|}{ Plutonium } & \multicolumn{2}{|c|}{ Americium } \\
\hline & $\mathbf{S}$ & I & S & I & $\mathbf{s}$ & I & $\mathbf{S}$ & I \\
\hline Lung & NA & 0.12 & NA & 0.12 & NA & 0.12 & $\mathrm{NA}$ & 0.12 \\
\hline Bone & - & - & 0.028 & 0.0137 & 0.2 & 0.1 & 0.063 & 0.0315 \\
\hline Liver & 0.02 & $0.005^{c}$ & - & - & 0.038 & 0.019 & 0.088 & 0.044 \\
\hline GI & 0.5 & 0.62 & 0.5 & 0.62 & 0.5 & 0.62 & 0.5 & 0.62 \\
\hline
\end{tabular}

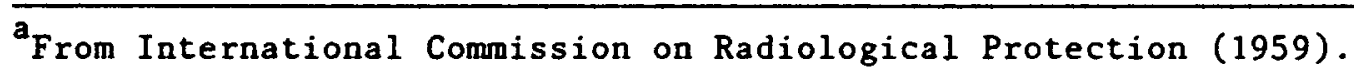

$\mathrm{b}_{\mathrm{S}}=$ soluble; $I$ = insoluble; $\mathrm{NA}=$ not applicable; - = no data available.

${ }^{C}$ Calculated from Hoenes and Soldat (1977).

Table B.4. Continuous Release Dose Commitment

Factor, $F\left(d^{2}\right)$

\begin{tabular}{|c|c|c|c|}
\hline \multirow[b]{2}{*}{ Nuclide } & \multicolumn{3}{|c|}{ Factor per Organ } \\
\hline & Lung & Bone $^{a}$ & Liver \\
\hline Cobalt -60 & $3.0 \mathrm{E} 6$ & - & $2.5 \mathrm{E} 5$ \\
\hline Plutonium-238 & $9.3 \mathrm{E} 6$ & $1.4 \mathrm{E} 8$ & $1.3 \mathrm{E} 8$ \\
\hline Plutonium-239 & $9.3 \mathrm{E} 6$ & $1.6 \mathrm{E} 8$ & $1.5 \mathrm{E} 8$ \\
\hline Plutonium-240 & $9.3 \mathrm{E} 6$ & $1.6 \mathrm{E} 8$ & $1.5 \mathrm{E} 8$ \\
\hline Plutonium-24i & $8.9 \mathrm{E} 6$ & $8.0 \mathrm{E7}$ & $7.4 \mathrm{E} 7$ \\
\hline Plutonium-242 & $9.3 \mathrm{E} 6$ & $1.6 \mathrm{E} 8$ & $1.5 \mathrm{E} 8$ \\
\hline Americium-241 & $3.1 \mathrm{E} 6$ & $1.5 \mathrm{E} 8$ & $6.7 \mathrm{E} 7$ \\
\hline
\end{tabular}


Table B.5. Dose Commitment Ratio, DCR

\begin{tabular}{lccc}
\hline & \multicolumn{3}{c}{ Ratio per Organ } \\
\cline { 2 - 4 } Nuclide & Lung & Bone $^{\mathrm{a}}$ & Liver $^{\mathrm{b}}$ \\
\hline Cobalt-60 & 1.00 & - & 1.00 \\
Uranium-234 & 1.06 & 0.99 & - \\
Uranium-235 & 1.03 & 1.01 & - \\
Uranium-236 & 1.06 & 1.01 & - \\
Uranium-238 & 1.06 & 1.03 & - \\
Plutonium-238 & 1.07 & 1.86 & 1.77 \\
Plutonium-239 & 1.07 & 1.87 & 1.79 \\
Plutonium-240 & 1.07 & 1.87 & 1.79 \\
Plutonium-241 & 0.91 & 1.41 & 1.39 \\
Plutonium-242 & 1.08 & 1.93 & 1.84 \\
Americium-241 & 1.06 & 2.00 & 1.31 \\
\hline
\end{tabular}

${ }^{a}$ No data available for cobalt.

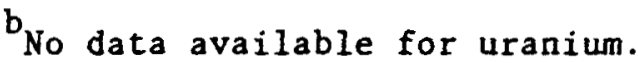




\section{REFERENCES (Appendix B)}

Hoenes, G.R., and J.K. Soldat. 1977. "Age-Specific Radiation Dose Commitment Factors for a One-Year Chronic Intake." U.S. Nuclear Regulatory Commission Report NUREG-0172. November 1977.

International Commission on Radiological Protection. 1959. "Report of Committee II on Permissible Dose for Internal Radiation." ICRP Publ. 2. Pergamon Press, New York.

Killough, G.G., and L.R. McKay. 1976. "A Methodology for Calculating Radiation Doses from Radioactivity Released to the Environment." Oak Ridge National Laboratory Report ORNL-4992. March 1976.

Sagendorf, J.R., and J.T. Goll. 1977. "XOQDOQ, Program for the Meteorological Evaluation of Routine Effluent Releases at Nuclear Power Stations." NUREG-0324 (Draft). U.S. Nuclear Regulatory Commission. September 1977.

Task Group on Lung Dynamics. 1966. "Deposition and Retention Models for Internal Dosimetry of the Human Respiratory Tract." Health Phys. 12:173-207.

Turner, D.B. 1970. "Workbook of Atmospheric Dispersion Estimates." Publ. No. AP-26. U.S. Environmental Protection Agency, Office of Air Programs.

U.S. Atomic Energy Commission. 1974. "Assumptions Used for Evaluating the Potential Radiological Consequences of a Loss of Coolant Accident for Boiling Water Reactors." Regulatory Guide 1.3 (Revision 2). June 1974.

U.S. Nuclear Regulatory Commission. 1976. "Preparation of Environmental Reports for Nuclear Power Stations." Regulatory Guide 4.2 (Revision 2). July 1976. 


\section{APPENDIX C. MANAGEMENT PLAN FOR THE ONSITE FALLOW DEER POPULATION}

\section{C.1 INTRODUCTION}

In developing the background for an EA of the operations of ANL, it became evident that the Laboratory. should prepare a management plan for the population of European fallow deer located on the Illinois site. The fallow deer is a species introduced to the United States that does not or has not occurred naturally in habitats of North America. The ANL herd has grown to a size where it can present a safety hazard for vehicular traffic, it has led to noticeable degradation of onsite vegetation, and it could impact the adjacent DuPage County Forest Preserve. The fallow deer population on the ANL site falls under the purview of Executive Order 11987 (May 24, 1977) regarding exotic organisms. This order mandates that executive agencies shall restrict the introduction of exotic species into natural ecosystems which they own or administer and encourage other governmental entities and private citizens to prevent the introduction of exotic species to natural ecosystems of the United States. In the spirit of this order, ANL presents a plan for managing and controlling the ANL population of fallow deer in a manner such that it does not expand into adjoining forest preserve areas. The potential for impacts from the deer must be mitigated by ANL-site managers in order to meet the intent of the National Environmental Policy Act of 1969.

\section{C.2. BACKGROUND}

\section{C.2.1 Taxonomy and Distribution}

Fallow deer belong to the deer family Cervidae, one of seven families belonging to the order Artiodactyla, even-toed ungulates or cloven-hooved mammals. This species belongs to the genus Dama, and the European fallow deer (Dama d. dama) is a congener of the endangered Persian fallow deer ( $D$. d. mesopotamica) (Chapman and Chapman 1975). Fallow deer belong to a subfamily of deer distinct from North American deer. The modern fallow deer probably dispersed from Asia Minor and southeastern Europe into the remainder of Europe. Much of this dispersal was effected by the active participation of humans.

The European fallow deer is currently distributed throughout nonScandinavian Europe in free-ranging populations (Chapman and Chapman 1980). In addition, populations have been established (purposefully and inadvertently) in South America, Republic of South Africa, Australia, New Zealand, Canada, and the United States. Free-ranging populations of fallow deer are now established in eight states of the United States. 


\section{C.2.2 History}

The history of the European fallow deer on the site began in the early 1930 s by one account and the early 1940 s by another (Anonymous 1952, 1967). The deer were eventually allowed to freely roam the estate of the late Edwin Freund, a part of which became the ANL site. A majority of the deer were removed from the estate at one point and the remainder (perhaps as few as two) served as the progenitors for the herd as it exists today.

In 1952, the number of fallow deer inhabiting the Argonne site was estimated at about one dozen. Since that time, the herd has increased to the point where an estimated 400 deer ( 1978 census) inhabit the current site and surrounding forest preserve land, about 1500 ha (Table C.1). Most of the deer are maintained within the perimeter fence of the current ANL site of about 690 ha. Since 1970, about 30 to 100 head of fallow deer have been removed from the site on four different occasions.

Table C.1. Census of Fallow Deer

\begin{tabular}{|c|c|c|c|c|c|}
\hline \multirow[b]{2}{*}{ Year } & \multirow[b]{2}{*}{ Spring Census } & \multirow[b]{2}{*}{ Method } & \multicolumn{3}{|c|}{$\begin{array}{c}\text { Deer Removed During } \\
\text { Previous Winter }\end{array}$} \\
\hline & & & Males & Females & Total \\
\hline 1970 & 163 & Helicopter & 20 & 7 & 27 \\
\hline 1971 & 161 & Helicopter & - & - & 0 \\
\hline 1972 & 140 & Helicopter & - & - & 0 \\
\hline 1973 & 243 & Helicopter & - & - & 0 \\
\hline 1974 & No count & - & - & - & 0 \\
\hline 1975 & 275 & Ground & 30 & 50 & 80 \\
\hline 1976 & 431 & Ground & $?$ & $?$ & 59 \\
\hline 1977 & $\begin{array}{l}283 \\
251\end{array}$ & $\begin{array}{l}\text { Helicopter } \\
\text { Ground }\end{array}$ & - & - & 0 \\
\hline 1978 & $382^{a}$ & Ground & $?$ & $?$ & 114 \\
\hline 1979 & $\begin{array}{c}149-183 \\
152\end{array}$ & $\begin{array}{l}\text { Ground } \\
\text { Helicopter }\end{array}$ & $?$ & $?$ & 261 \\
\hline $1981^{b}$ & $201-307$ & Ground & $?$ & $?$ & 75 \\
\hline
\end{tabular}




\section{3 ASPECTS OF FALLOW DEER ECOLOGY \\ C.3.1 Food Habits}

European fallow deer are generally considered to be grazers, feeding on low-growing grasses and forbs (Chapman and Chapman 1975). From spring to early fall, these forage categories make up $80-90 \%$ of the diet of free-ranging fallow deer. Broad-leafed trees may also make up part of the diet during the summer and fall months. Shrubs and conifers take on greater importance through the fall and winter months. Open water does not appear to be a major source of water for the European fallow deer.

The food habits of the European fallow deer contrast with those of the North American white-tailed deer (Odocoileus virginianus). Native deer are primarily browsers, feeding on the foliage, twigs, and buds of shrubs and trees.

Unfortunately, there have been no studies of the diet of fallow deer on the Argonne site. Casual observations of deer feeding appear to be consistent with the data from European studies (Chapman and Chapman 1975). At Argonne, deer are frequently observed grazing in open meadows dominated by grasses and crown-vetch. Even when the ground is covered by snow, deer will dig open patches for grazing. However, the well-defined browse lines in most of the woodlots indicate that a substantial portion of their dietary requirements are met by browsing shrub and tree shoots. During the fall, sumac is very heavily browsed to the point of losing most of its summer growth.

\section{C.3.2 Habitat Requirements}

Fallow deer occupy a variety of habitats throughout the world (Chapman and Chapman 1975, 1980; Rogers and Myers 1980). Generally, populations become established in areas combining deciduous woodlands or scrublands and open grasslands or meadowlands. The dense canopies of the woodlands and scrublands provide shelter, and the herbaceous ground cover of the open areas provides a major portion of the diet. Plants from well-developed herbaceous understories of woodlands can also form a major portion of the diet. In some areas, e.g. coastal California, fallow deer inhabit areas of evergreen scrubland interspersed with evergreen oak savannah. Coniferous woodlands are also inhabited by fallow deer where open land is in proximity.

The ANL site appears to provide appropriate habitat for fallow deer. Prior to establishment of the Laboratory, about $75 \%$ of the site consisted of agricultural fields; $25 \%$ of the site was occupied by grazed oak woodlots and scattered oak forest (Messenger et al. 1969). In the early 1950s, some of the former agricultural fields were planted with jack, white, and red pine. Open fields along rights-of-way and in the central portions of the site were planted with crown-vetch to provide erosion control and low-maintenance ground cover. These open areas are dominated by crown-vetch and bluegrasses. On the site periphery are examples of secondary succession on abandoned agricultural lands; these, areas are dominated by bluegrasses, a number of common forbs (including yarrow, Queen-Anne's-lace, goldenrod, and ragweed), and scattered shrubs (including blackberry, cherry, and hawthorne). 
The deciduous woodlands are dominated by several species of oak in addition to hawthornes, hickory, and ash. In some areas saplings, shrubs, and herbaceous plants form heavy understories. Understories are very poorly developed in the coniferous woodlots. Woodlots vary from closed to relatively open canopies.

Thus, various biotic communities on the Argonne site provide a diverse mosaic of habitat suited for establishment of the fallow deer population.

\section{C.3.3 Population Dynamics}

As noted earlier, the fallow deer population at the ANL site has grown from a herd of about a dozen in the early 1950 s to a minimum of 400 head by the late 1970s (Table C.1). The deer population appears to be in the exponential phase of the growth curve. The deer herd has no natural predators at the Argonne site, and the four major causes of individual deer mortality are vehicular accidents, starvation, disease, and old age. These appear to be the major random factors likely to limit the size of the deer herd at this time, and thus the population size is likely to oscillate with the availability of food, weather conditions, and consequent physiological condition of individual deer. Unfortunately, there are no data that clearly relate the population size to the severe winters of 1977-1978 and 1978-1979 and the subsequent two mild winters. The population decline from $1976-1977$ is associated with a severe winter, but the causal relationship cannot be established.

To date, there have been four efforts to remove excess deer from the Argonne site. In no case did these removals result in a decline in the size of the censused deer herd from the previous year. However, there may have been a reduction in the rate of growth due to the removal of individuals.

The censusing of deer by ground or aerial observation yields a count of the minimum number of deer known to occur in the census area. The estimates of the fallow deer on the Argonne site are then underestimates of the actual population size. The magnitude of the underestimation is not known. However, investigation of censusing methods suggests that they could be as low as $40-50 \%$ of the actual population size (Rice and Harder 1978; Kuffel et al. 1980; Floyd et al. 1979).

The Argonne site currently (1978 estimates) supports between 0.8 and 1.6 individuals per hectare (assuming a herd size of 400-800 and a woodland/ grassland area of $500 \mathrm{ha}$ ). Chapman and Chapman (1975) indicate that a wellstocked park in England typically contains about 0.5 deer/ha. This density is, however, higher than fallow deer herds in large ranges $(>\sim 1500$ ha) with low levels of management; in these situations, typical densities range from 0.02 to 0.07 individuals per hectare (Chapman and Chapman 1980). It appears that the Argonne herd is currently at a density higher than that considered typical for highly managed, free-living populations of this species in England. The Argonne herd is probably one of the most concentrated populations of fallow deer in the United States.

\section{C.3.4 Competition}

The fallow deer is the primary large mammalian grazer on the Argonne site. Because the population size appears to be at the higher limits of most managed population sizes for the species, it is likely that intraspecific 
competition for food becomes a factor in reducing herd size during severe winters. Starvation and malnutrition appear to be the primary factors that can reduce the population size if the Argonne herd remains unmanaged.

There may be some interaction between fallow deer and native white-tailed deer at the periphery of the Argonne site and in the adjacent forest preserve. Although no formal studies have been made, there is no apparent evidence that fallow deer are currently interfering with native deer. Competition for food between the two species should not be high since fallow deer are primarily grazers and white-tailed deer are browsers; nor do the ranges of the two species appear to overlap to a large degree on the ANL site. However, if the fallow deer population continues to grow at an accelerated rate, there is the possibility that competition between the two species may increase. This may become a factor during severe winters, when fallow deer are more dependent upon browse and probably expand their foraging range into the adjacent forest preserve.

\section{C.3.5 Human Interactions}

The fallow deer on the Argonne site are considered by some to be an asset to the general environment of the Laboratory. The deer are often visible to employees and visitors alike and add to the rural atmosphere achieved by the interspersion of woodland and meadowland areas among the work areas.

The increasing population of fallow deer does pose some problems for site managers. The major problem with the deer today is that they often become traffic hazards. About 40 individuals per year are involved in traffic accidents on the Argonne site (Argonne Natl. Lab. 1978). Accelerated growth of the population will surely increase this hazard.

The deer have produced a well-marked browse line in most of the woodlots onsite, and heavy browsing is noticeable on many of the shrubs in late fall and early spring. The deer are currently impacting onsite vegetation, and increased foraging pressure is already reducing the aesthetic appearance of some of the wooded areas. Expansion of the deer herd into adjacent areas could result in similar degradation of vegetation in the forest preserve.

Other problems associated with an increased fallow deer population include:

- Development of a conspicuous network of deerpaths in the woodlots.

- Increased erosion along streambanks due to frequent passage of deer.

- Damage to fencing due to deer crossing.

- Unsightly deposits of deer feces in areas of human activity.

- Browsing of managed plantings both onsite and offsite. 


\section{4 MANAGEMENT STRATEGY}

Because of the advantages of having a herd of fallow deer onsite and the disadvantages of an oversized herd, Laboratory management has implemented a management plan. The plan basically consists of the following management strategy:

- Regular surveys of the deer herd are undertaken at annual intervals using standard wildlife techniques for estimating population size, natality, mortality, and environmental damage.

- A herd size of about 200 individuals will be maintained by removing the appropriate number of does, as needed: The estimate of optimal herd size should be reassessed periodically in light of the above survey information.

- To the extent practicable, culled individuals will be donated to deer parks, zoos, or other organizations that are sufficiently well-maintained to prevent the escape of deer to the wild. Final disposition of deer will be accurately determined to avoid enhancing the spread of this exotic species (see Executive Order 11987).

- ANL will cooperate with state and forest preserve wildlife personnel to minimize offsite impacts of the fallow deer.

- A deer management committee has been established consisting of an onsite biologist, a representative from the ANL Office of Public Affairs, the ANL Environmental Coordinator, and the Plant Maintenance Director.

\section{REFERENCES (Appendix C)}

Anonymous. 1952. "White deer roam wooded areas at Argonne." The Argonne News, 2 April 1952, p. 3. Argonne National Laboratory, Argonne IL.

Anonymous. 1967. "Former owner pays sentimental visit." Argonne News, August 1967, pp. 10-11. Argonne National Laboratory, Argonne IL.

Argonne National Laboratory. 1978. "Terrestrial and Aquatic Information Packages." Argonne, II. December 15, 1978.

Chapman, D., and N. Chapman. 1975. "Fallow Deer, Their History, Distribution and Biology." Terence Dalton Ltd., Lavenham, England.

Chapman, N.G., and D.I. Chapman. 1980. "The distribution of fallow deer: a worldwide review." Mammal. Rev. 10:61-138.

Floyd, T.J., L.D. Mech, and M.E. Nelson. 1979. "An improved method of censusing deer in deciduous-coniferous forests." J. Wildl. Manage. 43:258-261.

Kufeld, R.C., J.H. Olderman, and D.C. Bowden. 1980. "A helicopter quadrant census for mule deer on Uncompaghie Plateau, Colorado." J. Wildl. Manage. 44:632-639. 
Messenger, A.S., W.R. Suter, and J.A. Wagner. 1969. "Ecological Survey of Argonne National Laboratory." Argonne National Laboratory Report ANL-7559.

Rice, W.R., and J.D. Harden. 1977. "Application of multiple aerial sampling to a mark-recapture census of white-tailed deer." J. Wildl. Manage. 41:197-206.

Rogers, P.M., and K. Myers. 1980. "Animal distributions, landscape classification and wildlife management, Cota Doñana, Spain." J. Appl. Ecol. $17: 545-565$. 
APPENDIX D. TABLE OF METRIC/ENGLISH EQUIVALENTS

\begin{tabular}{|c|c|c|}
\hline Multiply & By & To obtain \\
\hline Centimeters (cm) & 0.3937 & Inches \\
\hline Cubic meters $\left(\mathrm{m}^{3}\right)$ & $2.6417 \times 10^{2}$ & Gallons \\
\hline Cubic meters $\left(\mathrm{m}^{3}\right)$ & 35.3146 & Cubic feet \\
\hline Cubic meters $\left(\mathrm{m}^{3}\right)$ & 1.308 & Cubic yards \\
\hline Cubic meters per hour $\left(\mathrm{m}^{3} / \mathrm{h}\right)$ & 4.4029 & Gallons per minute \\
\hline $\begin{array}{l}\text { Cubic meters per minute } \\
\left(\mathrm{m}^{3} / \mathrm{min}\right)\end{array}$ & 0.58858 & Cubic feet per second \\
\hline Cubic meters per second $\left(\mathrm{m}^{3} / \mathrm{s}\right)$ & $15.8503 \times 10^{3}$ & Gallons/minute \\
\hline Degrees Celsius $\left({ }^{\circ} \mathrm{C}\right)+17.78$ & 1.8 & Degrees Fahrenheit \\
\hline Grams (g) & 0.0353 & Ounces \\
\hline Hectares (ha) & 2.471 & Acres \\
\hline Joules (J) & $9.485 \times 10-4$ & British thermal units \\
\hline Joules (J) & $2.778 \times 10-7$ & Kilowatthours \\
\hline Kilograms (kg) & 2.2046 & Pounds \\
\hline Kilograms (kg) & 0.001102 & Tons, short \\
\hline Kilograms per hour $(\mathrm{kg} / \mathrm{h})$ & 0.03675 & Pounds per minute \\
\hline Kilometers (km) & 0.6214 & Miles \\
\hline Kilopascals (kPa) & 0.14504 & Pounds per square inch \\
\hline Liters (L) & 0.2642 & Gallons \\
\hline Liters per second (L/s) & 15.8503 & Gallons per minute \\
\hline Meters (m) & 3.2808 & Feet \\
\hline Meters per second $(\mathrm{m} / \mathrm{s})$ & 2.2369 & Miles per hour \\
\hline Milligrams (mg) & $3.5274 \times 10-5$ & Ounces \\
\hline Millimeters (mm) & 0.03937 & Inches \\
\hline Pascals (Pa) & 0.02089 & Pounds per square foot \\
\hline Square meters $\left(\mathrm{m}^{2}\right)$ & 10.764 & Square feet \\
\hline Square meters $\left(\mathrm{m}^{2}\right)$ & 1.1960 & Square yards \\
\hline Tons, metric ( $t)$ & 1.1023 & Tons, short \\
\hline
\end{tabular}

NOTE : $\mu g / g=p p m ; m g / L \cong p p m$ (in water). 